
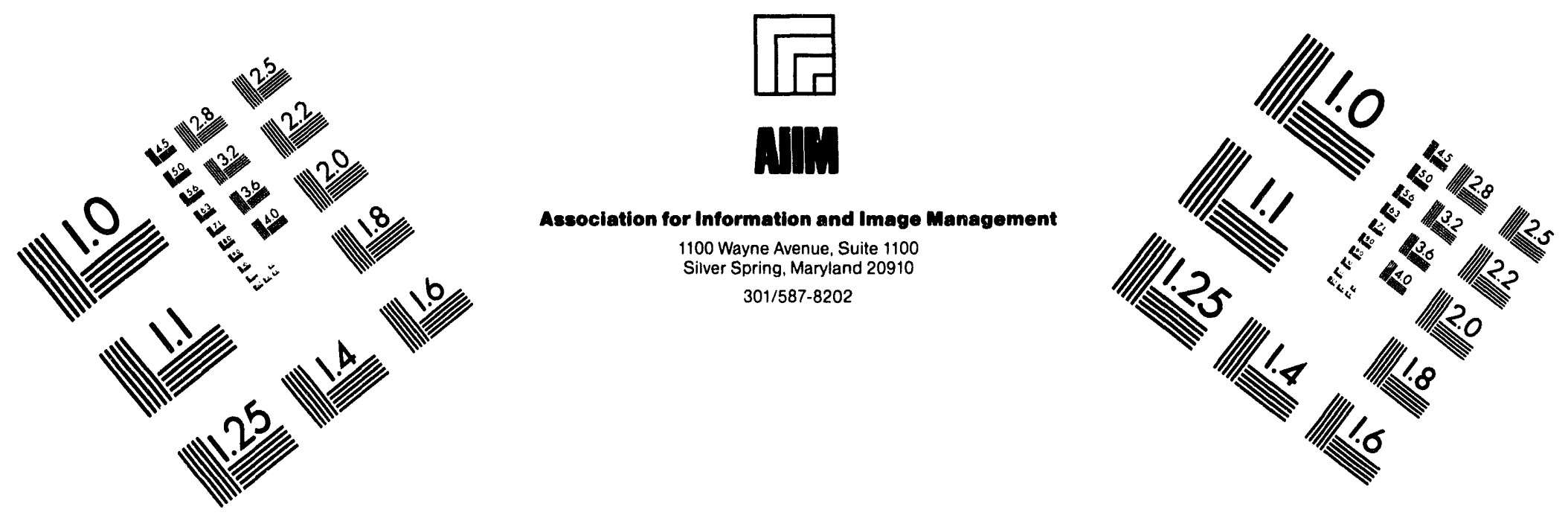

\title{
Centimeter
}

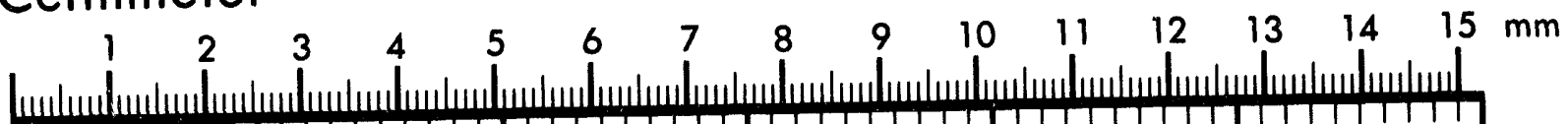
m1 Inches
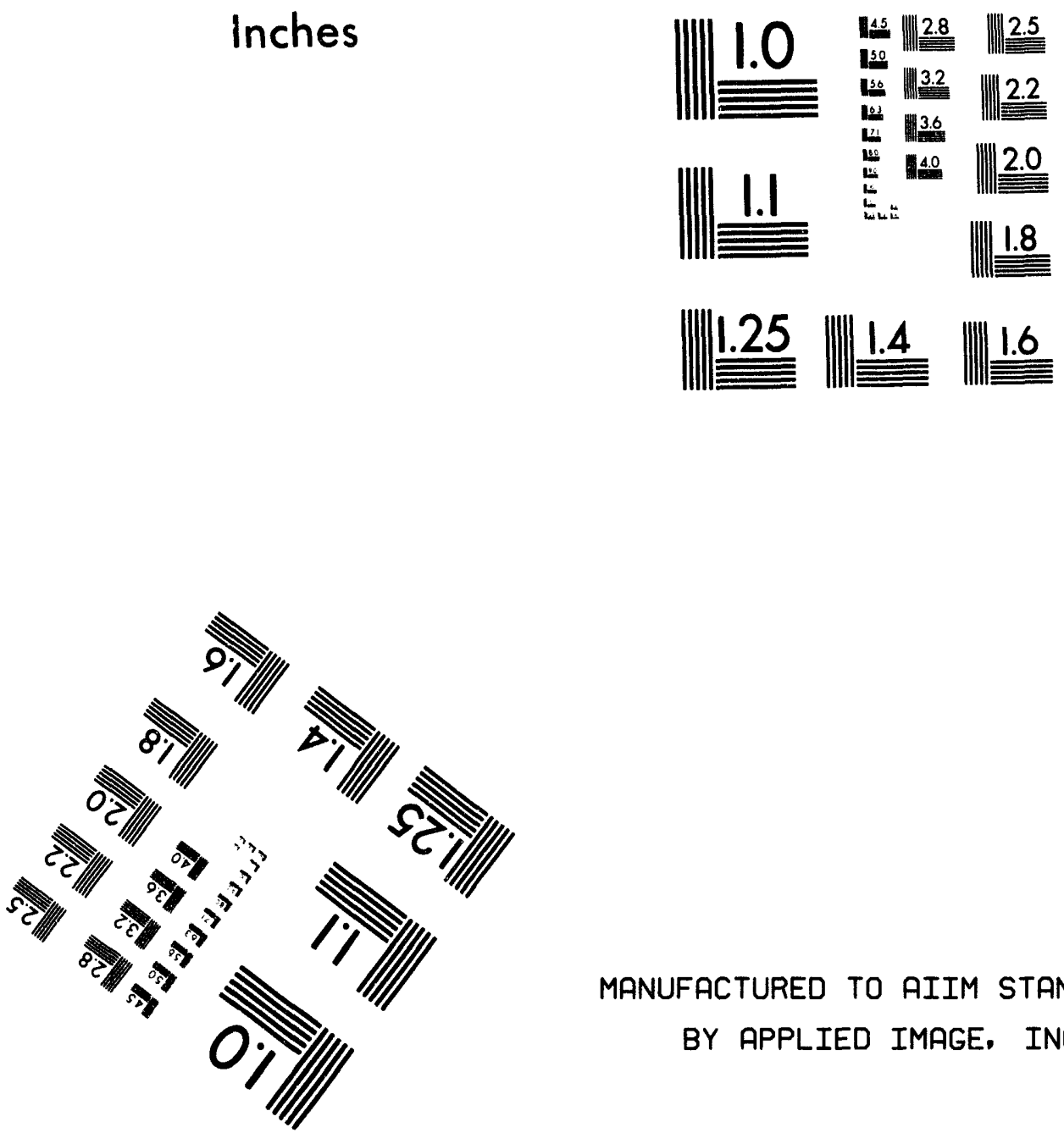

MANUFACTURED TO AIIM STANDARDS

BY APPLIED IMAGE, INC.

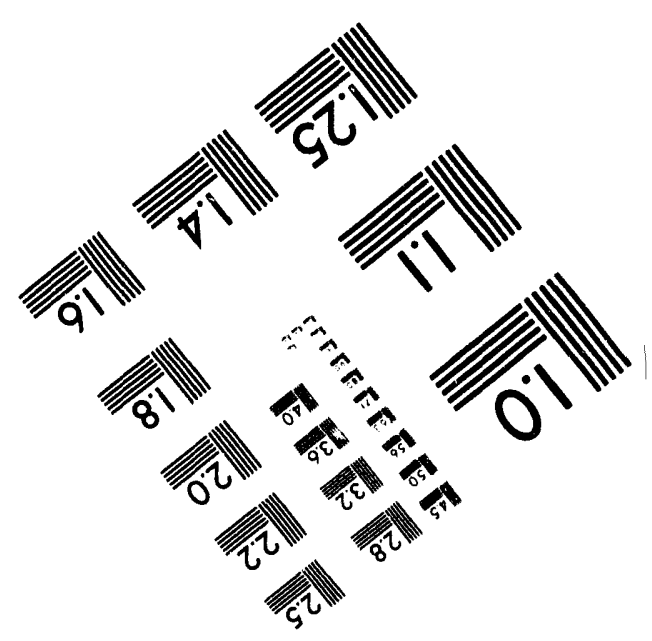



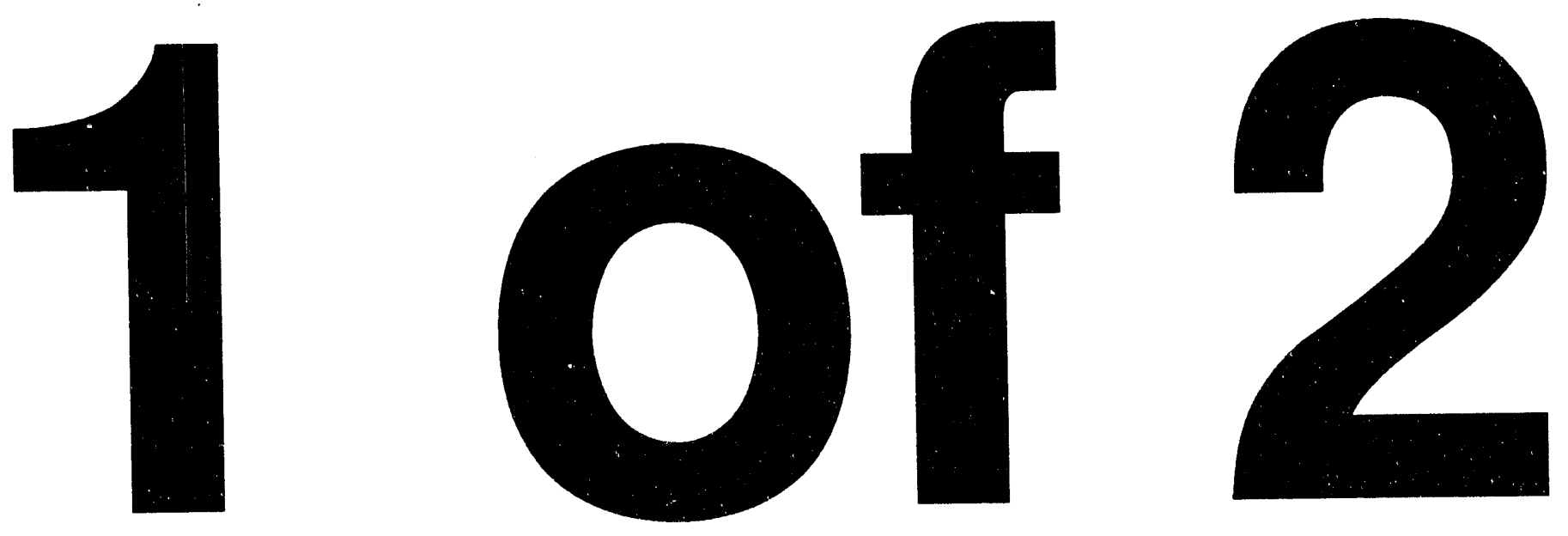


\title{
RFPFIVED \\ APR 111994 \\ OS TI
}

\section{Energy Information Directory 1994}

\author{
March 1994
}

\author{
Energy Information Administration \\ National Energy Information Center \\ U.S. Department of Energy \\ Washington, DC 20585
}

This report was prepared by the Energy Information Administration, the independent statistical and analytical agency within the Department of Energy. The information contained herein should not be construed as advocating or necessarily reflecting any policy position of the Department of Energy or of any other organization. 


\title{
Preface
}

The National Energy Information Center (NEIC), as part of its mission, provides energy information and referral assistance to Federal, State, and local governments, the academic community, business and industrial organizations, and the general public. The two principal functions related to this task are (1) operating a general access telephone line, and (2) responding to energy-related correspondence addressed to the Energy Information Administration (EIA). The Energy Information Directory was developed to assist the NEIC staff, as well as other Department of Energy (DOE) staff, in directing inquiries to the proper offices within DOE, other Federal agencies, or energy-related trade associations.

The Directory is a list of most Government offices and trade associations that are involved in energy matters.
It does not include those DOE offices which do not deal with the public or public information. For the purposes of this publication, each entry has been given a numeric identification symbol. The index found in the back of this publication uses these identification numbers to refer the reader to relevant entries.

The Directory is published annually, with each issue superseding the previous issue. However, due to organizational changes throughout DOE and EIA, there is no edition of the Directory for either 1992 or 1993. Questions concerning the content of an entry should be directed to Leola Withrow at (202) 586-1171 or FTS 896-1171. The Directory is free and can be obtained from NEIC at the following address:

\author{
National Energy Information Center \\ Energy Information Administration \\ U.S. Department of Energy \\ EI-231, Forrestal Building \\ Washington, DC 20585 \\ (202) $586-8800$ \\ TTY: For people who are deaf \\ or hard of hearing: (202) 586-1181
}




\section{Contents}

INFORMATION CENTERS

Conservation and Renewable Energy

and Referral Service

Energy Science and Technology Software Center $\ldots \ldots \ldots \ldots \ldots \ldots \ldots \ldots \ldots$

National Appropriate Technology Assistance Services $\ldots \ldots \ldots \ldots \ldots \ldots \ldots \ldots \ldots$

National Energy Information Center $\ldots \ldots \ldots \ldots \ldots \ldots \ldots \ldots \ldots \ldots \ldots \ldots$

National Institute for Petroleum and Energy Research $\ldots \ldots \ldots \ldots \ldots \ldots \ldots \ldots$

Office of Scientific and Technical Information $\ldots \ldots \ldots \ldots \ldots \ldots \ldots \ldots \ldots \ldots$

DEPARTMENT OF ENERGY/WASHINGTON $\ldots \ldots \ldots \ldots \ldots \ldots \ldots \ldots \ldots \ldots$

Departmental Advisory Committees $\ldots \ldots \ldots \ldots \ldots \ldots \ldots \ldots \ldots \ldots \ldots \ldots \ldots \ldots \ldots \ldots$

American Statistical Association

Committee on Energy Statistics $\ldots \ldots \ldots \ldots \ldots \ldots \ldots \ldots \ldots \ldots \ldots \ldots \ldots \ldots \ldots$

Environmental Restoration

and Waste Management Advisory Committee $\ldots \ldots \ldots \ldots \ldots \ldots \ldots \ldots \ldots \ldots$

Basic Energy Sciences Advisory Committee $\ldots \ldots \ldots \ldots \ldots \ldots \ldots \ldots \ldots \ldots$

Health and Environmental Research Advisory Committee $\ldots \ldots \ldots \ldots \ldots \ldots \ldots$

High Energy Physics Advisory Panel $\ldots \ldots \ldots \ldots \ldots \ldots \ldots \ldots \ldots \ldots \ldots \ldots$

National Coal Council $\ldots \ldots \ldots \ldots \ldots \ldots \ldots \ldots \ldots \ldots \ldots \ldots \ldots \ldots \ldots \ldots \ldots$

National Petroleum Council $\ldots \ldots \ldots \ldots \ldots \ldots \ldots \ldots \ldots \ldots \ldots \ldots \ldots$

Secretary of Energy Advisory Board $\ldots \ldots \ldots \ldots \ldots \ldots \ldots \ldots \ldots \ldots \ldots \ldots \ldots$

Office of the Assistant Secretary for Congressional, Intergovernmental, and International Affairs (CI) 
Office of Resource Management $\ldots \ldots \ldots \ldots \ldots \ldots \ldots \ldots \ldots \ldots \ldots \ldots \ldots$

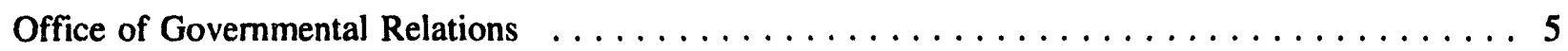

Office of the Deputy Assistant Secretary

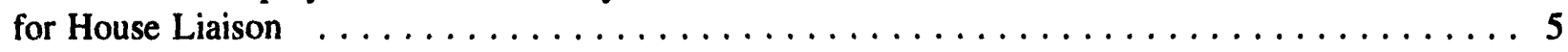

Office of the Deputy Assistant Secretary

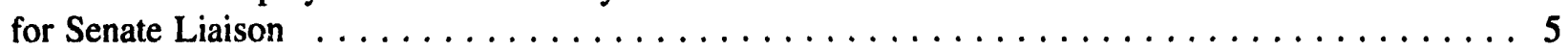

Office of the Assistant Secretary for Defense Programs (DP) $\ldots \ldots \ldots \ldots \ldots \ldots \ldots \ldots \ldots$

Office of the Deputy Science and Technology Advisor $\ldots \ldots \ldots \ldots \ldots \ldots \ldots$

Office of the Principal Deputy Assistant Secretary

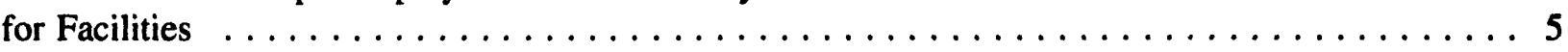

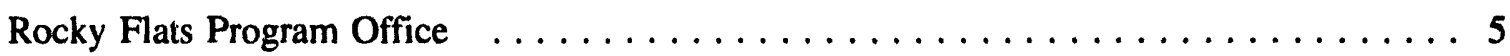

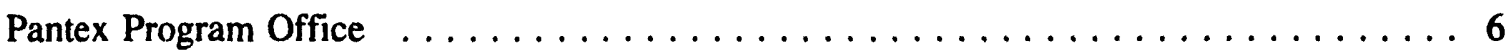

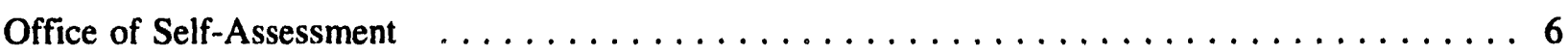

Office of the Deputy Assistant Secretary

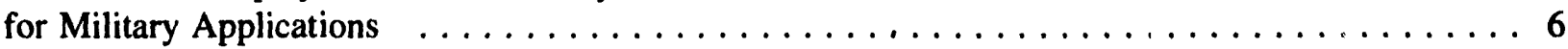

Office of Transportation Safeguards

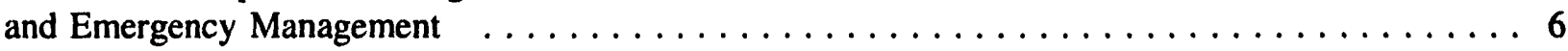

Office of Research and Advanced Technology $\ldots \ldots \ldots \ldots \ldots \ldots \ldots \ldots \ldots$

Office of Development, Testing, and Acquisition $\ldots \ldots \ldots \ldots \ldots \ldots \ldots \ldots$

Office of Weapons and Materials Planning $\ldots \ldots \ldots \ldots \ldots \ldots \ldots \ldots \ldots \ldots \ldots \ldots \ldots \ldots \ldots$

Office of Inertial Confinement Fusion $\ldots \ldots \ldots \ldots \ldots \ldots \ldots \ldots \ldots \ldots \ldots \ldots \ldots \ldots \ldots$

Office of the Deputy Assistant Secretary

for Weapons Complex Reconfiguration $\ldots \ldots \ldots \ldots \ldots \ldots \ldots \ldots \ldots \ldots \ldots \ldots \ldots \ldots \ldots \ldots \ldots$

Office of the Deputy Assistant Secretary

for Resource Management $\ldots \ldots \ldots \ldots \ldots \ldots \ldots \ldots \ldots \ldots \ldots \ldots \ldots \ldots$

Office of the Deputy Assistant Secretary for Facilities $\ldots \ldots \ldots \ldots \ldots \ldots \ldots$

Office of Engineering and Operations Support $\ldots \ldots \ldots \ldots \ldots \ldots \ldots \ldots \ldots \ldots$

Office of Processing and Reactor Facilities $\ldots \ldots \ldots \ldots \ldots \ldots \ldots \ldots \ldots \ldots \ldots$

Office of Production Facilities $\quad \ldots \ldots \ldots \ldots \ldots \ldots \ldots \ldots \ldots \ldots \ldots \ldots \ldots \ldots$ 
Office of Research, Development and Testing Facilities $\ldots \ldots \ldots \ldots \ldots \ldots \ldots$

Office of Construction and Capital Projects $\ldots \ldots \ldots \ldots \ldots \ldots \ldots \ldots \ldots \ldots$

Office of Inspections $\ldots \ldots \ldots \ldots \ldots \ldots \ldots \ldots \ldots \ldots \ldots \ldots \ldots \ldots \ldots$

Office of Field Security Oversight $\ldots \ldots \ldots \ldots \ldots \ldots \ldots \ldots \ldots \ldots \ldots \ldots$

Office of Economic Impact and Diversity (ED) $\ldots \ldots \ldots \ldots \ldots \ldots \ldots \ldots \ldots$

Office of Minority Economic Impact $\ldots \ldots \ldots \ldots \ldots \ldots \ldots \ldots \ldots \ldots \ldots$

Office of Small and Disadvantaged Business Utilization $\ldots \ldots \ldots \ldots \ldots \ldots$

Office of the Assistant Secretary

for Energy Efficiency and Renewable Energy (EE) $\ldots \ldots \ldots \ldots \ldots \ldots \ldots \ldots \ldots$

Office of the Deputy Assistant Secretary

for Utility Technologies $\ldots \ldots \ldots \ldots \ldots \ldots \ldots \ldots \ldots \ldots \ldots \ldots \ldots \ldots$

Office of Renewable Energy Conversion $\ldots \ldots \ldots \ldots \ldots \ldots \ldots \ldots \ldots \ldots$

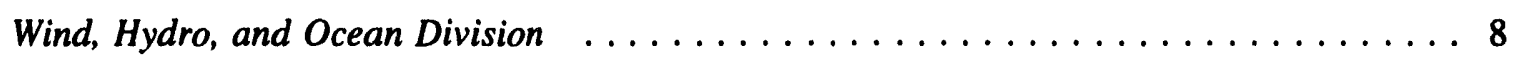

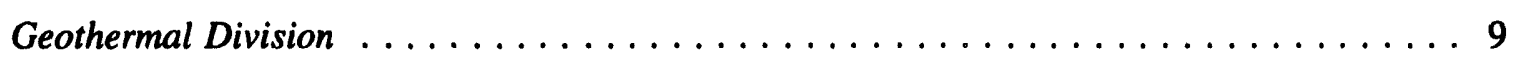

Office of Solar Energy Conversion $\ldots \ldots \ldots \ldots \ldots \ldots \ldots \ldots \ldots \ldots \ldots$

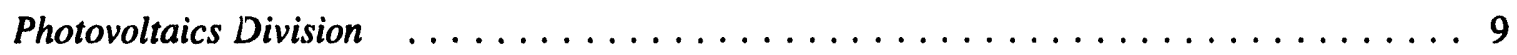

Solar Thermal and Biomass Power Division $\ldots \ldots \ldots \ldots \ldots \ldots \ldots$

Office of Energy Management $\quad \ldots \ldots \ldots \ldots \ldots \ldots \ldots \ldots \ldots \ldots \ldots$

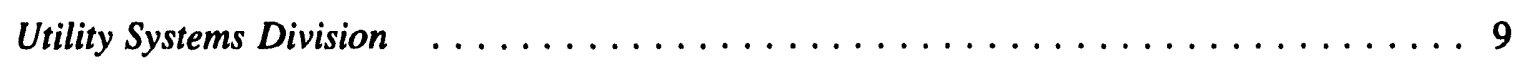

Advanced Utility Concepts Division $\quad \ldots \ldots \ldots \ldots \ldots \ldots \ldots \ldots \ldots \ldots \ldots \ldots \ldots \ldots \ldots \ldots$

Office of the Deputy Assistant Secretary

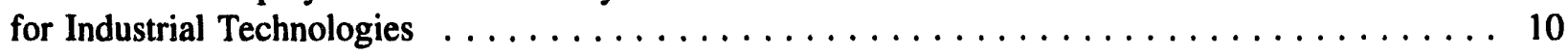

Office of Waste Reduction Technologies $\ldots \ldots \ldots \ldots \ldots \ldots \ldots \ldots \ldots$

Industrial Energy Efficiency Division $\ldots \ldots \ldots \ldots \ldots \ldots \ldots \ldots \ldots \ldots \ldots$

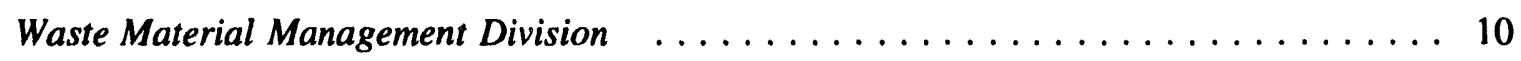

Implementation and Deployment Division $\ldots \ldots \ldots \ldots \ldots \ldots \ldots \ldots \ldots \ldots$ 


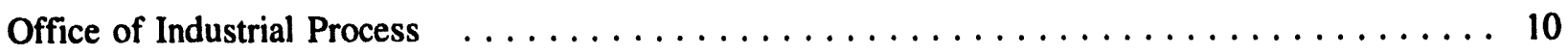

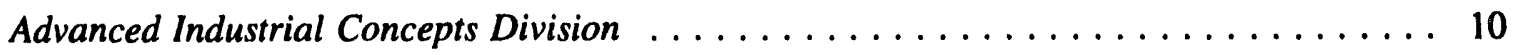

Separations Division $\ldots \ldots \ldots \ldots \ldots \ldots \ldots \ldots \ldots \ldots \ldots \ldots \ldots \ldots$

Material Processing Division ........................... 11

Office of the Deputy Assistant Secretary

for Transportation Technologies $\ldots \ldots \ldots \ldots \ldots \ldots \ldots \ldots \ldots \ldots \ldots \ldots \ldots \ldots$

Office of Propulsion Systems $\ldots \ldots \ldots \ldots \ldots \ldots \ldots \ldots \ldots \ldots \ldots \ldots \ldots \ldots \ldots$

Electric/Hybrid Propulsion Division $\ldots \ldots \ldots \ldots \ldots \ldots \ldots \ldots \ldots \ldots \ldots$

Advanced Propulsion Division $\ldots \ldots \ldots \ldots \ldots \ldots \ldots \ldots \ldots \ldots \ldots \ldots$

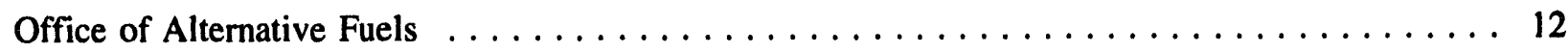

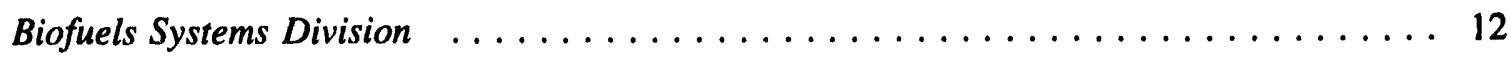

Fuels Utilization Data and Analysis Division $\ldots \ldots \ldots \ldots \ldots \ldots \ldots \ldots \ldots \ldots$

Office of Advanced Transportation Materials $\ldots \ldots \ldots \ldots \ldots \ldots \ldots \ldots \ldots \ldots \ldots \ldots \ldots$

Office of the Deputy Assistant Secretary

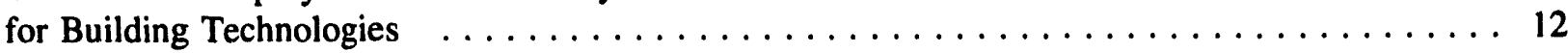

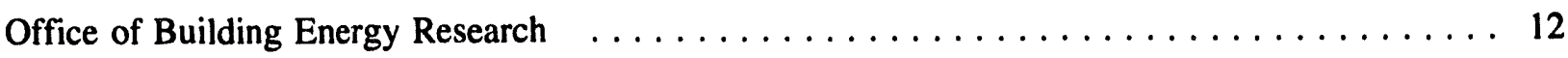

Building Systems and Materials Division $\ldots \ldots \ldots \ldots \ldots \ldots \ldots \ldots \ldots$

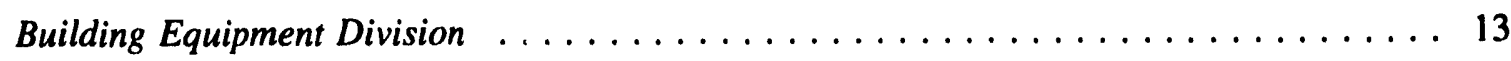

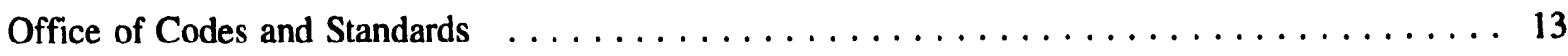

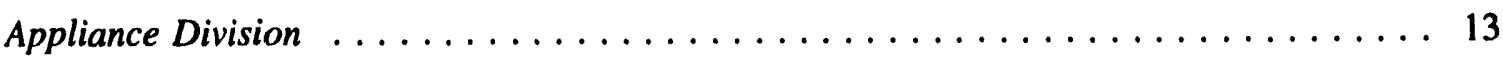

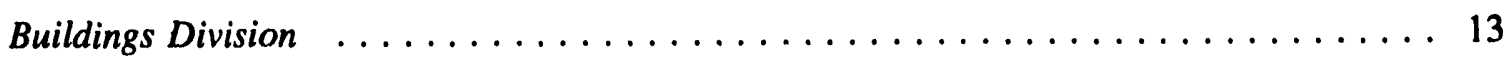

Office of Federal Energy Management Programs $\ldots \ldots \ldots \ldots \ldots \ldots \ldots \ldots \ldots \ldots$

Office of the Deputy Assistant Secretary

for Technical and Financial Assistance $\ldots \ldots \ldots \ldots \ldots \ldots \ldots \ldots \ldots \ldots \ldots \ldots$

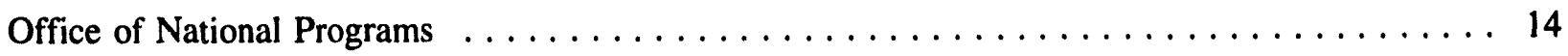

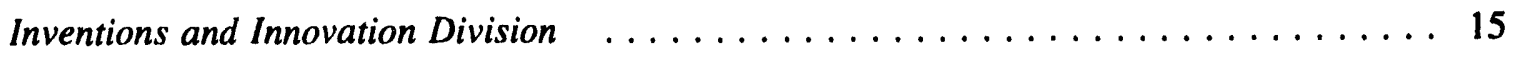




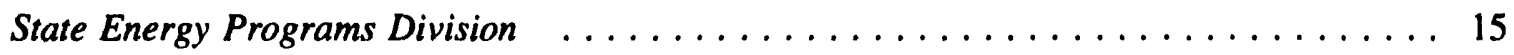

Office of Grants Management $\ldots \ldots \ldots \ldots \ldots \ldots \ldots \ldots \ldots \ldots \ldots \ldots \ldots$

Institutional Conservation Program Division $\ldots \ldots \ldots \ldots \ldots \ldots \ldots \ldots \ldots \ldots$

Weatherization Assistance Program Division $\ldots \ldots \ldots \ldots \ldots \ldots \ldots \ldots \ldots \ldots$

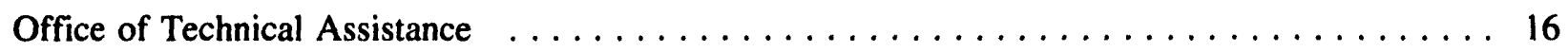

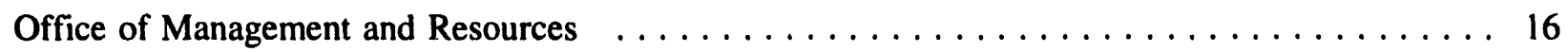

Management Systems Institutional

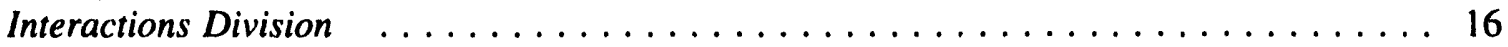

Budget and Financial Management Division $\ldots \ldots \ldots \ldots \ldots \ldots \ldots \ldots$

Facilities and Systems Coordination Division $\ldots \ldots \ldots \ldots \ldots \ldots \ldots \ldots \ldots$

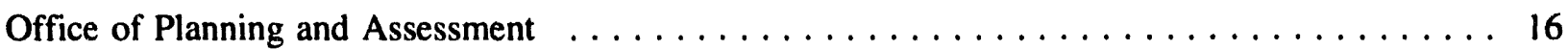

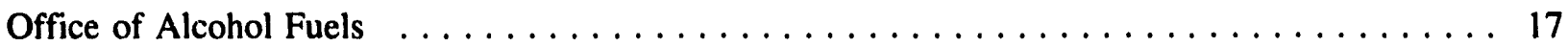

Office of the Assistant Secretary

for Environment, Safety and Health $(\mathbf{E H}) \ldots \ldots \ldots \ldots \ldots \ldots \ldots \ldots \ldots$

Office of the Deputy Assistant Secretary

for Security Evaluations $\ldots \ldots \ldots \ldots \ldots \ldots \ldots \ldots \ldots \ldots \ldots \ldots$

Office of Inspections $\ldots \ldots \ldots \ldots \ldots \ldots \ldots \ldots \ldots \ldots \ldots \ldots \ldots$

Office of Plans, Technology and Certification $\ldots \ldots \ldots \ldots \ldots \ldots \ldots \ldots$

Office of Special Projects $\ldots \ldots \ldots \ldots \ldots \ldots \ldots \ldots \ldots \ldots \ldots \ldots \ldots$

Office of the Deputy Assistant Secretary
for Nuclear Safety $\ldots \ldots \ldots \ldots \ldots \ldots \ldots \ldots \ldots \ldots \ldots \ldots \ldots \ldots \ldots \ldots \ldots \ldots \ldots$

Office of Nuclear Safety Performance Assessment $\ldots \ldots \ldots \ldots \ldots \ldots$

Office of Nuclear Safety Risk and Policy Analysis $\ldots \ldots \ldots \ldots \ldots \ldots$

Office of Nuclear Safety Enforcement $\ldots \ldots \ldots \ldots \ldots \ldots \ldots \ldots \ldots \ldots \ldots$

Office of Nuclear Safety Field Programs $\ldots \ldots \ldots \ldots \ldots \ldots \ldots \ldots \ldots$

Office of Nuclear Safety Technical Support

and Systems Management $\ldots \ldots \ldots \ldots \ldots \ldots \ldots \ldots \ldots \ldots \ldots \ldots \ldots$ 
Office of Nuclear Safety Radiological Oversight $\ldots \ldots \ldots \ldots \ldots \ldots \ldots$

Office of the Deputy Assistant Secretary

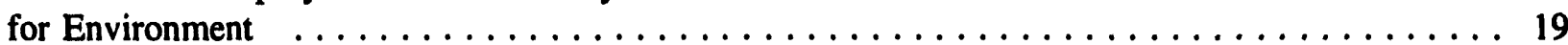

Office of Environmental Compliance $\ldots \ldots \ldots \ldots \ldots \ldots \ldots \ldots \ldots \ldots$

Compliance Strategies Division $\ldots \ldots \ldots \ldots \ldots \ldots \ldots \ldots \ldots \ldots \ldots \ldots$

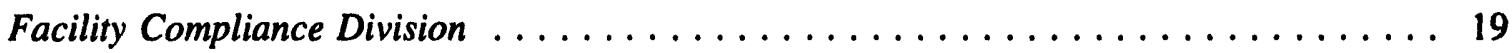

Office of Environmental Guidance $\quad \ldots \ldots \ldots \ldots \ldots \ldots \ldots \ldots \ldots \ldots$

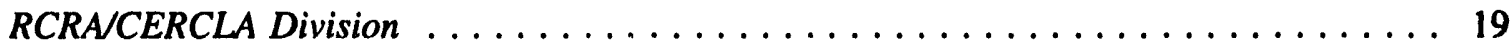

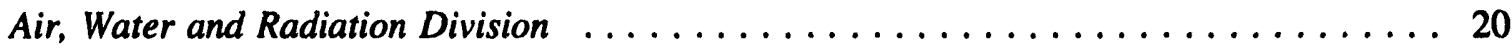

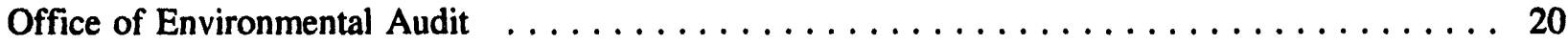

Office of National Environmental Policy

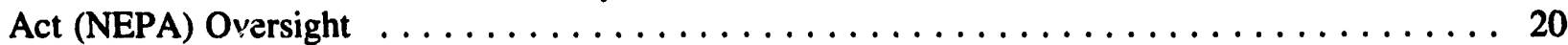

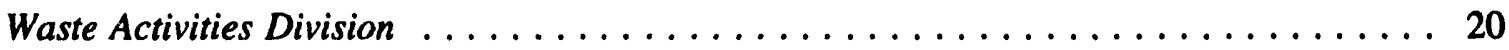

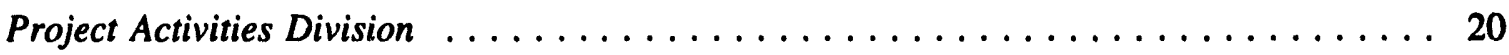

Office of the Deputy Assistant Secretary

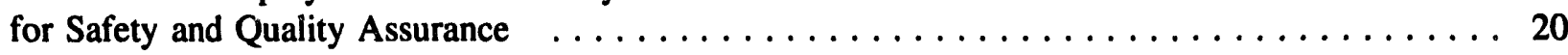

Resident Program Staff $\ldots \ldots \ldots \ldots \ldots \ldots \ldots \ldots \ldots \ldots \ldots \ldots \ldots \ldots$

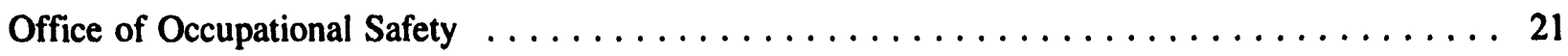

Policy and Standards Division $\ldots \ldots \ldots \ldots \ldots \ldots \ldots \ldots \ldots \ldots \ldots \ldots \ldots$

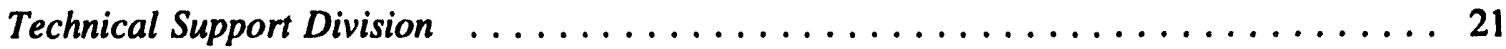

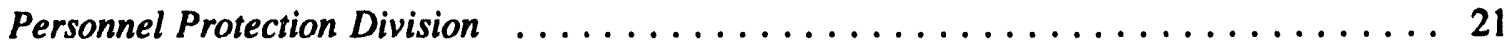

Safety Performance Indicator Division $\ldots \ldots \ldots \ldots \ldots \ldots \ldots \ldots \ldots \ldots \ldots$

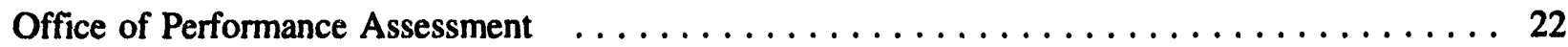

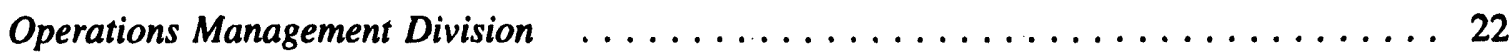

Performance and Quality Verification Division $\ldots \ldots \ldots \ldots \ldots \ldots \ldots \ldots \ldots$

Office of Risk Analysis and Technology $\ldots \ldots \ldots \ldots \ldots \ldots \ldots \ldots \ldots \ldots$ 
Risk Analysis and Technology Division $\ldots \ldots \ldots \ldots \ldots \ldots \ldots \ldots \ldots \ldots \ldots \ldots$

Transportation and Packaging Safety Division $\ldots \ldots \ldots \ldots \ldots \ldots \ldots \ldots \ldots$

Office of the Deputy Assistant Secretary for Health $\ldots \ldots \ldots \ldots \ldots \ldots \ldots$

Office of Health Physics and Industrial Hygiene $\ldots \ldots \ldots \ldots \ldots \ldots \ldots \ldots \ldots$

Office of Epidemiology and Health Surveillance $\ldots \ldots \ldots \ldots \ldots \ldots \ldots \ldots$

Office of Occupational Medicine $\ldots \ldots \ldots \ldots \ldots \ldots \ldots \ldots \ldots \ldots \ldots \ldots \ldots$

Energy Information Administration (EIA) $\ldots \ldots \ldots \ldots \ldots \ldots \ldots \ldots \ldots \ldots \ldots \ldots \ldots$

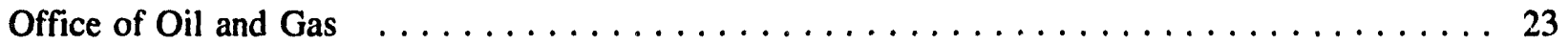

Petroleum Supply Division $\ldots \ldots \ldots \ldots \ldots \ldots \ldots \ldots \ldots \ldots \ldots \ldots \ldots \ldots$

Petroleum Marketing Division $\ldots \ldots \ldots \ldots \ldots \ldots \ldots \ldots \ldots \ldots \ldots \ldots$

Reserves and Natural Gas Division $\ldots \ldots \ldots \ldots \ldots \ldots \ldots \ldots \ldots \ldots \ldots$

Office of Coal, Nuclear, Electric and Alternate Fuels $\ldots \ldots \ldots \ldots \ldots \ldots \ldots$

Survey Management Division $\ldots \ldots \ldots \ldots \ldots \ldots \ldots \ldots \ldots \ldots \ldots \ldots \ldots$

Analysis and Systems Division $\ldots \ldots \ldots \ldots \ldots \ldots \ldots \ldots \ldots \ldots \ldots \ldots \ldots$

Office of Energy Markets and End Use $\ldots \ldots \ldots \ldots \ldots \ldots \ldots \ldots \ldots \ldots \ldots$

Energy Markets and Contingency Information Division $\ldots \ldots \ldots \ldots \ldots \ldots \ldots$

End Use and Integrated Statistics Division $\ldots \ldots \ldots \ldots \ldots \ldots \ldots \ldots \ldots \ldots$

Office of Statistical Standards $\ldots \ldots \ldots \ldots \ldots \ldots \ldots \ldots \ldots \ldots \ldots \ldots \ldots \ldots \ldots \ldots$

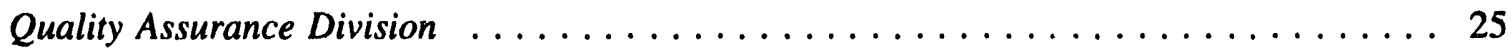

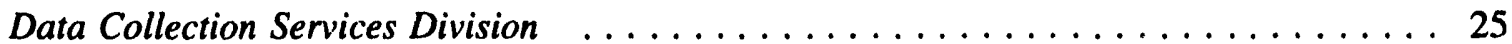

Office of Integrated Analysis and Forecasting $\ldots \ldots \ldots \ldots \ldots \ldots \ldots \ldots \ldots$

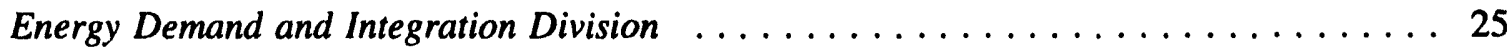

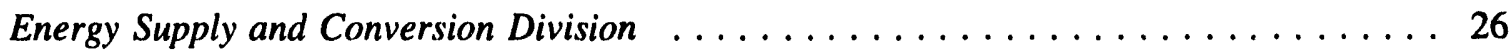

Office of the Assistant Secretary for Environmental Restoration

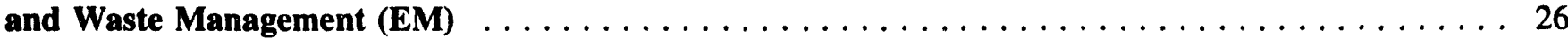


Office of the Deputy Assistant Secretary for Oversight and Self Assessment $\ldots \ldots \ldots 26$

Office of the Deputy Assistant Secretary Waste Management $\ldots \ldots \ldots \ldots \ldots$

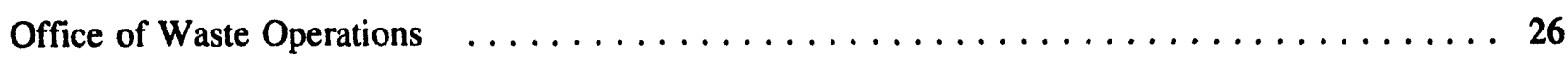

Office of Program Support, Waste Management $\ldots \ldots \ldots \ldots \ldots \ldots \ldots$

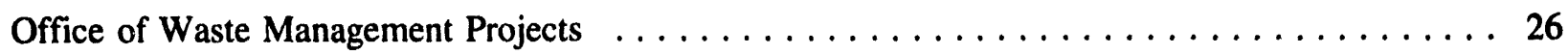

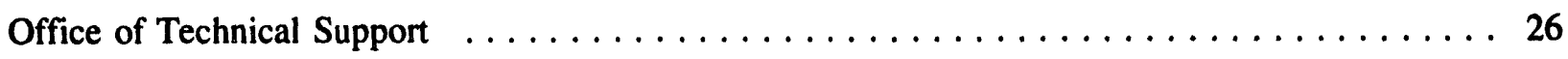

Office of the Deputy Assistant Secretary for Environmental Restoration $\ldots \ldots \ldots \ldots \ldots$

Office of Eastern Area Programs $\ldots \ldots \ldots \ldots \ldots \ldots \ldots \ldots \ldots \ldots \ldots \ldots$

Office of Program Support, Environmental Restoration $\ldots \ldots \ldots \ldots \ldots \ldots \ldots$

Office of Northwestern Area Programs $\ldots \ldots \ldots \ldots \ldots \ldots \ldots \ldots \ldots \ldots$

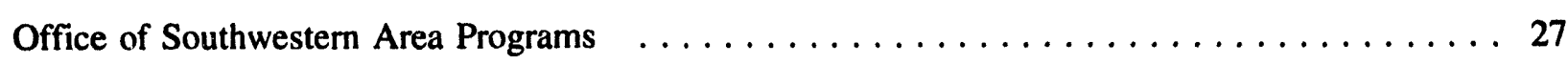

Office of the Deputy Assistant Secretary for Technology Development $\ldots \ldots \ldots \ldots$. . . . 27

Office of Technology Integration and Environmental Education and Development $\ldots \ldots \ldots 27$

Office of Program Support and Technology Development $\ldots \ldots \ldots \ldots \ldots \ldots \ldots$

Office of Research and Development $\ldots \ldots \ldots \ldots \ldots \ldots \ldots \ldots \ldots \ldots \ldots \ldots$

Office of Demonstration Testing and Evaluation $\ldots \ldots \ldots \ldots \ldots \ldots \ldots \ldots$

Office of Special Programs $\ldots \ldots \ldots \ldots \ldots \ldots \ldots \ldots \ldots \ldots \ldots \ldots \ldots \ldots$

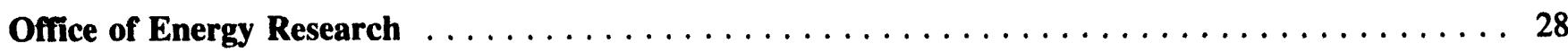

Office of Assessment and Support $\ldots \ldots \ldots \ldots \ldots \ldots \ldots \ldots \ldots \ldots \ldots \ldots \ldots$

Safety and Health Protection Division $\ldots \ldots \ldots \ldots \ldots \ldots \ldots \ldots \ldots \ldots$

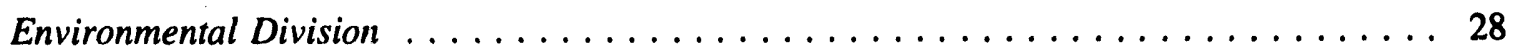

Office of Basic Energy Sciences $\ldots \ldots \ldots \ldots \ldots \ldots \ldots \ldots \ldots \ldots \ldots \ldots \ldots \ldots$

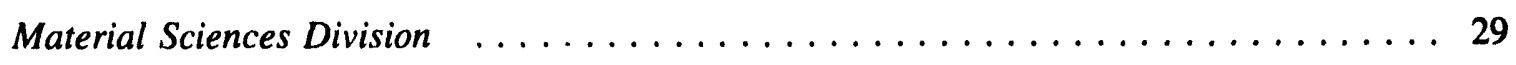

Chemical Sciences Division $\ldots \ldots \ldots \ldots \ldots \ldots \ldots \ldots \ldots \ldots \ldots \ldots$

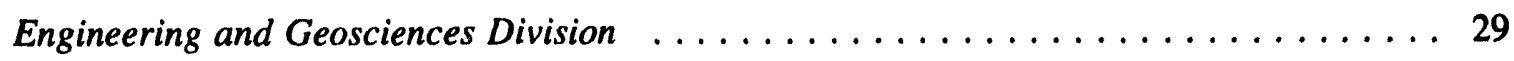




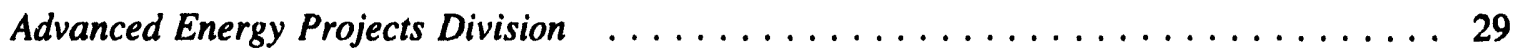

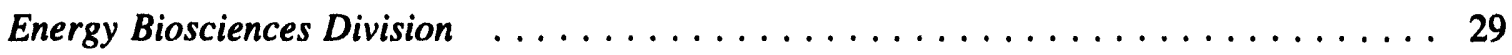

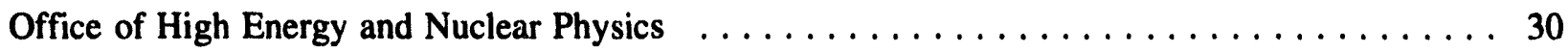

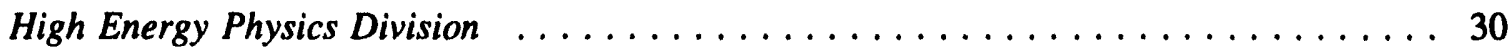

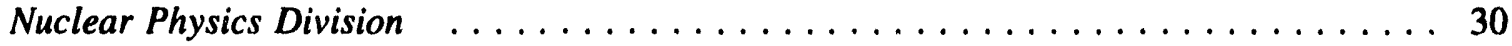

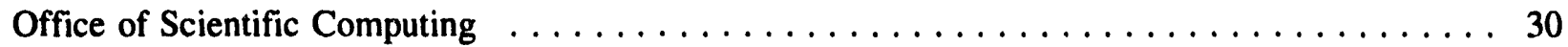

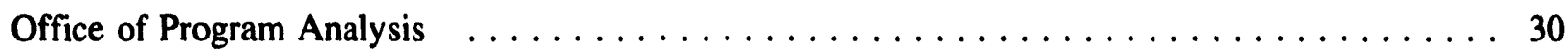

Research and Technical Assessment Division $\ldots \ldots \ldots \ldots \ldots \ldots \ldots \ldots \ldots \ldots \ldots$

Program Integration Analysis Division $\ldots \ldots \ldots \ldots \ldots \ldots \ldots \ldots \ldots \ldots \ldots \ldots$

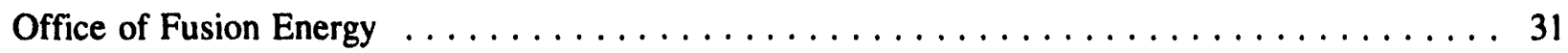

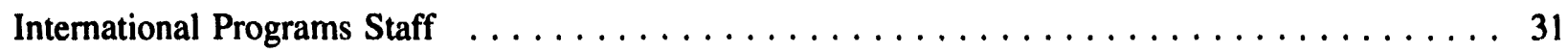

International Thermonuclear Experimental Reactor and Technology Division _... . . 31

Advanced Physics and Technology Division $\ldots \ldots \ldots \ldots \ldots \ldots \ldots \ldots \ldots \ldots$

Confinement Systems Division $\ldots \ldots \ldots \ldots \ldots \ldots \ldots \ldots \ldots \ldots \ldots \ldots \ldots \ldots \ldots$

Office of Health and Environmental Research $\ldots \ldots \ldots \ldots \ldots \ldots \ldots \ldots$

Health Effects and Life Sciences Research Division $\ldots \ldots \ldots \ldots \ldots \ldots \ldots$

Medical Applications and Biophysical Research Division $\ldots \ldots \ldots \ldots \ldots \ldots$

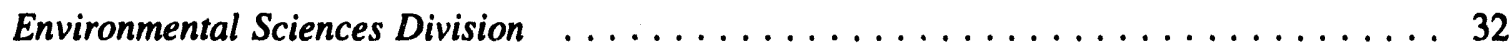

Office of Superconducting Super Collider $\ldots \ldots \ldots \ldots \ldots \ldots \ldots \ldots \ldots$

Office of Science Education and Technical Information $($ ET) $\ldots \ldots \ldots \ldots \ldots \ldots$

Office of University and Science Education Programs $\ldots \ldots \ldots \ldots \ldots \ldots \ldots \ldots \ldots$

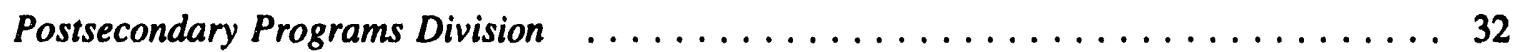

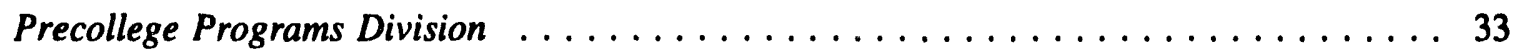

Office of the Assistant Secretary for Fossil Energy (FE) $\ldots \ldots \ldots \ldots \ldots \ldots \ldots$

Office of Planning and Environment $\ldots \ldots \ldots \ldots \ldots \ldots \ldots \ldots \ldots \ldots \ldots$ 


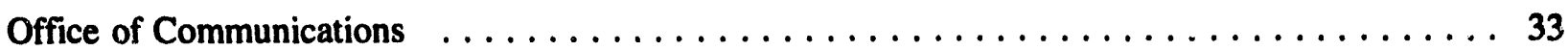

Office of Self Assessment $\ldots \ldots \ldots \ldots \ldots \ldots \ldots \ldots \ldots \ldots \ldots \ldots \ldots$

Office of the Deputy Assistant Secretary for Management $\ldots \ldots \ldots \ldots \ldots$

Office of Resource Management $\ldots \ldots \ldots \ldots \ldots \ldots \ldots \ldots \ldots \ldots \ldots \ldots \ldots$

Office of Business Operations $\ldots \ldots \ldots \ldots \ldots \ldots \ldots \ldots \ldots \ldots \ldots \ldots \ldots \ldots$

Office of the Deputy Assistant Secretary for Coal Technology $\ldots \ldots \ldots \ldots \ldots \ldots$

Office of the Associate Deputy Assistant Secretary for Clean Coal $\ldots \ldots \ldots \ldots \ldots \ldots$

Office of the Associate Deputy Assistant Secretary for Research and Development . . . . . . 34

Office of the Deputy Assistant Secretary for Gas and Petroleum Technology $\ldots \ldots \ldots \ldots$

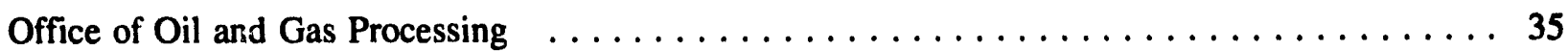

Office of Oil and Gas Exploration and Production $\ldots \ldots \ldots \ldots \ldots \ldots \ldots$

Office of the Deputy Assistant Secretary Strategic Petroleum Reserve $\ldots \ldots \ldots \ldots \ldots$

Office of Technical Management $\ldots \ldots \ldots \ldots \ldots \ldots \ldots \ldots \ldots \ldots \ldots \ldots \ldots \ldots$

Office of Management Operations $\ldots \ldots \ldots \ldots \ldots \ldots \ldots \ldots \ldots \ldots \ldots \ldots \ldots$

Office of the Deputy Assistant Secretary for Fuels Programs $\ldots \ldots \ldots \ldots \ldots \ldots$

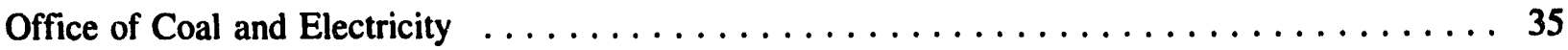

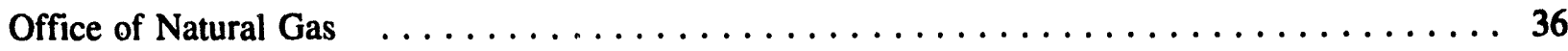

Office of the Deputy Assistant Secretary for Naval Petroleum and Oil Shale Reserves . . . . . 36

Office of the Deputy Assistant Secretary for Advanced Research and Special Technologies . . . . 36

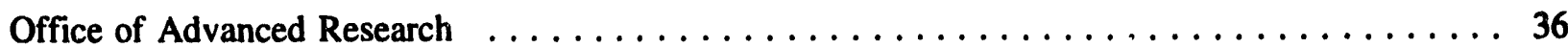

Office of Special Technologies $\ldots \ldots \ldots \ldots \ldots \ldots \ldots \ldots \ldots \ldots \ldots \ldots$

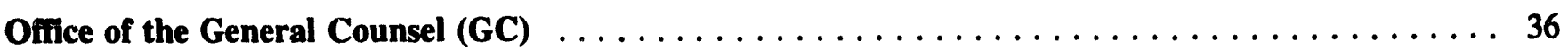

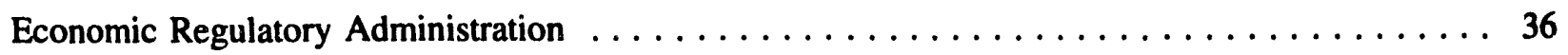

Administrative Litigation Division $\ldots \ldots \ldots \ldots \ldots \ldots \ldots \ldots \ldots \ldots \ldots \ldots \ldots$

Judicial Litigation Division $\ldots \ldots \ldots \ldots \ldots \ldots \ldots \ldots \ldots \ldots \ldots \ldots \ldots$ 


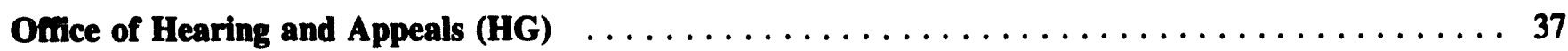

Office of Management Operations $\ldots \ldots \ldots \ldots \ldots \ldots \ldots \ldots \ldots \ldots \ldots \ldots \ldots \ldots$

Management Information Division $\ldots \ldots \ldots \ldots \ldots \ldots \ldots \ldots \ldots \ldots \ldots \ldots \ldots$

Docket and Publications Division $\ldots \ldots \ldots \ldots \ldots \ldots \ldots \ldots \ldots \ldots \ldots \ldots \ldots$

Office of Legal Analysis $\ldots \ldots \ldots \ldots \ldots \ldots \ldots \ldots \ldots \ldots \ldots \ldots \ldots$

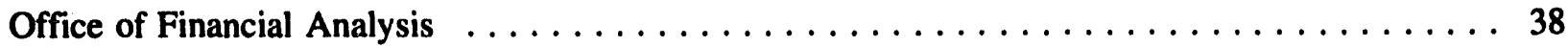

Office of Economic Analysis $\ldots \ldots \ldots \ldots \ldots \ldots \ldots \ldots \ldots \ldots \ldots \ldots \ldots \ldots$

Board of Contract Appeals $\ldots \ldots \ldots \ldots \ldots \ldots \ldots \ldots \ldots \ldots \ldots \ldots \ldots$

Ofince of the Assistant Secretary of Human Resources and Administration (HR)

Office of Procurement, Assessment, and Property $\ldots \ldots \ldots \ldots \ldots \ldots$

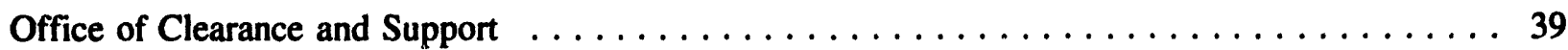

Office of Headquarters Procurement Operations $\ldots \ldots \ldots \ldots \ldots \ldots$

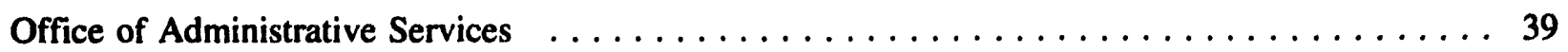

Reference and Information Management Division $\ldots \ldots \ldots \ldots \ldots \ldots \ldots$

Printing and Graphics Division $\ldots \ldots \ldots \ldots \ldots \ldots \ldots \ldots \ldots \ldots \ldots \ldots \ldots$

Office of Intelligence and National Security (IS)

Office of Arms Control and Nonproliferation $\ldots \ldots \ldots \ldots \ldots$

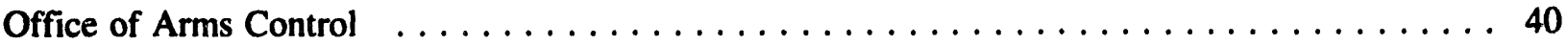

Policy and Technical Analysis Division $\ldots \ldots \ldots \ldots \ldots \ldots \ldots \ldots \ldots$

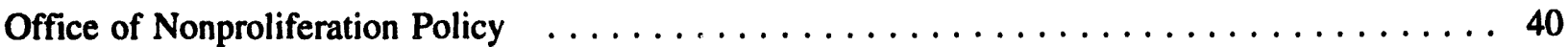

Office of Export Control and International Safeguards $\ldots \ldots \ldots \ldots \ldots \ldots$

Export Control Operations Division $\ldots \ldots \ldots \ldots \ldots \ldots \ldots \ldots \ldots \ldots \ldots \ldots$

International Safeguards Division $\ldots \ldots \ldots \ldots \ldots \ldots \ldots \ldots \ldots \ldots \ldots \ldots$

Office Emergency Management $\ldots \ldots \ldots \ldots \ldots \ldots \ldots \ldots \ldots \ldots \ldots \ldots$ 
Office of Laboratory Management (LiM) $\ldots \ldots \ldots \ldots \ldots \ldots \ldots \ldots \ldots \ldots \ldots$

Laboratory Management Division $\ldots \ldots \ldots \ldots \ldots \ldots \ldots \ldots \ldots \ldots \ldots \ldots$

Office of Technology Utilization $\ldots \ldots \ldots \ldots \ldots \ldots \ldots \ldots \ldots \ldots \ldots \ldots \ldots \ldots \ldots$

Office of Nuclear Energy (NE) $\quad \ldots \ldots \ldots \ldots \ldots \ldots \ldots \ldots \ldots \ldots \ldots \ldots \ldots \ldots \ldots \ldots \ldots$

Office of Policy and Management $\ldots \ldots \ldots \ldots \ldots \ldots \ldots \ldots \ldots \ldots \ldots \ldots \ldots \ldots$

International Programs Division $\ldots \ldots \ldots \ldots \ldots \ldots \ldots \ldots \ldots \ldots \ldots \ldots \ldots$

Reactor and Safety Assistance to Russia/Ukraine Division $\ldots \ldots \ldots \ldots \ldots \ldots \ldots$

Office of Uranium Programs $\ldots \ldots \ldots \ldots \ldots \ldots \ldots \ldots \ldots \ldots \ldots \ldots \ldots \ldots \ldots$

Enrichment Oversight and Uranium Revitalization Division $\ldots \ldots \ldots \ldots \ldots \ldots \ldots$

Facility and Technology Management Division $\ldots \ldots \ldots \ldots \ldots \ldots \ldots \ldots \ldots$

Office of Civilian Reactor Development $\ldots \ldots \ldots \ldots \ldots \ldots \ldots \ldots \ldots \ldots \ldots \ldots \ldots \ldots$

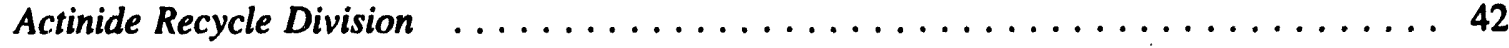

Advanced Neutron Source Division $\ldots \ldots \ldots \ldots \ldots \ldots \ldots \ldots \ldots \ldots \ldots \ldots \ldots$

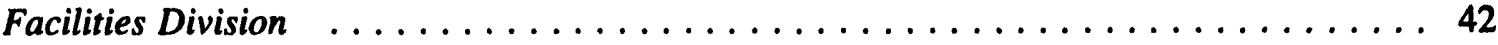

Advanced Light Water Reactors Division $\ldots \ldots \ldots \ldots \ldots \ldots \ldots \ldots \ldots \ldots \ldots$

Isotope Production and Distribution Division $\ldots \ldots \ldots \ldots \ldots \ldots \ldots \ldots \ldots \ldots$

Office of Space and Defense Power Systems $\ldots \ldots \ldots \ldots \ldots \ldots \ldots \ldots \ldots \ldots \ldots$

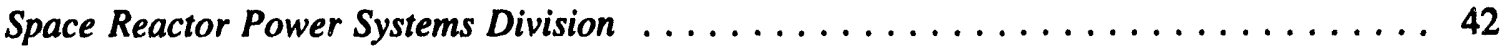

Radioisotope Power Systems Division $\ldots \ldots \ldots \ldots \ldots \ldots \ldots \ldots \ldots \ldots \ldots \ldots$

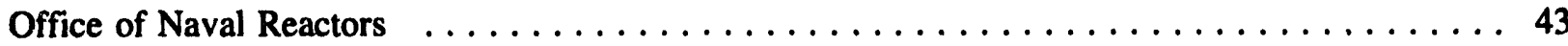

Office of Public and Consumer Affairs (PA) $\ldots \ldots \ldots \ldots \ldots \ldots \ldots \ldots \ldots \ldots \ldots \ldots$

Assistant Secretary for Policy, Planning and Program Evaluation (PO) $\ldots \ldots \ldots \ldots \ldots \ldots$

Office of the Deputy Assistant Secretary for Policy

Planning and Implementation $\ldots \ldots \ldots \ldots \ldots \ldots \ldots \ldots \ldots \ldots \ldots \ldots \ldots \ldots \ldots \ldots$

Office of Energy Demand Policy $\ldots \ldots \ldots \ldots \ldots \ldots \ldots \ldots \ldots \ldots \ldots \ldots \ldots \ldots$ 
Office of Electricity and Generating Fuels Policy $\ldots \ldots \ldots \ldots \ldots \ldots \ldots$

Office of Oil and Natural Gas Policy $\ldots \ldots \ldots \ldots \ldots \ldots \ldots \ldots \ldots \ldots$

Office of the Deputy Assistant Secretary for Economic and Environmental Policy $\ldots \ldots \ldots 44$

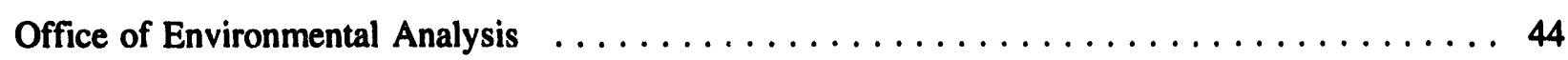

Office of Economic Analysis and Competition $\ldots \ldots \ldots \ldots \ldots \ldots \ldots \ldots \ldots$

Office of Program Review and Analysis $\ldots \ldots \ldots \ldots \ldots \ldots \ldots \ldots \ldots$

Office of Strategic Planning $\ldots \ldots \ldots \ldots \ldots \ldots \ldots \ldots \ldots \ldots \ldots \ldots$

Office of the Deputy Assistant Secretary for International Affairs $\ldots \ldots \ldots \ldots \ldots$

Office of International Research and Development Policy $\ldots \ldots \ldots \ldots \ldots$

Office of International Energy Analysis $\ldots \ldots \ldots \ldots \ldots \ldots \ldots \ldots \ldots$

International Energy Organizations and Policy Development Division . . . . . . . 45

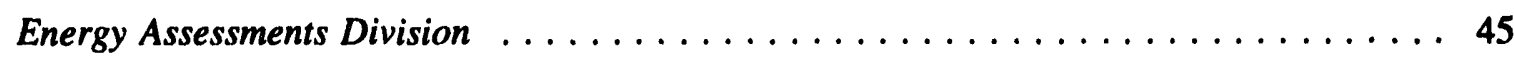

Ofince of Civilian Radioactive Waste Management $(\mathbf{R W}) \ldots \ldots \ldots \ldots \ldots$

Office of Quality Assurance $\ldots \ldots \ldots \ldots \ldots \ldots \ldots \ldots \ldots \ldots \ldots \ldots$

Office of Strategic Planning and International Programs $\ldots \ldots \ldots \ldots \ldots$

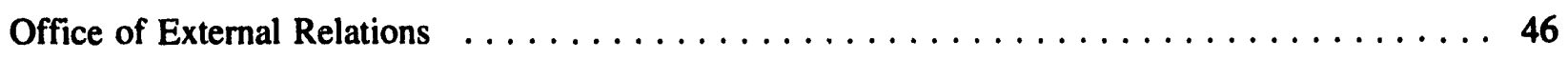

Office of Program and Resources Management $\ldots \ldots \ldots \ldots \ldots \ldots \ldots$

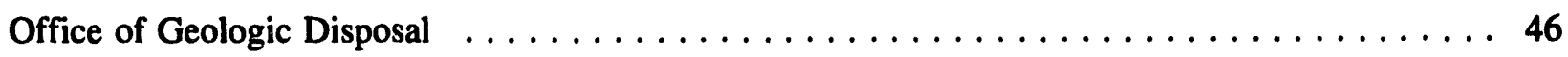

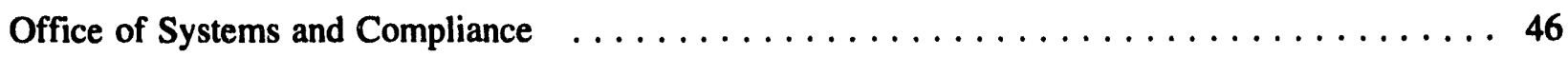

Office of Storage and Transportation $\ldots \ldots \ldots \ldots \ldots \ldots \ldots \ldots \ldots \ldots$

Office of Contract Business Management $\ldots \ldots \ldots \ldots \ldots \ldots \ldots \ldots \ldots \ldots \ldots$

Federal Energy Regulatory Commission (FERC) $\ldots \ldots \ldots \ldots \ldots \ldots \ldots \ldots \ldots$

Congressional Affairs and State Liaison $\ldots \ldots \ldots \ldots \ldots \ldots \ldots \ldots \ldots \ldots \ldots$

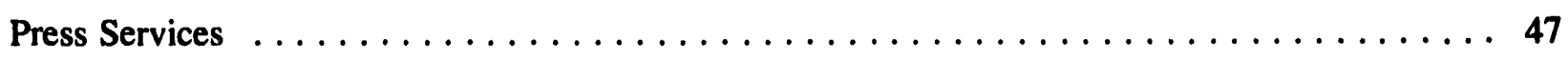

Public and Intergovernmental Affairs $\ldots \ldots \ldots \ldots \ldots \ldots \ldots \ldots \ldots \ldots \ldots$ 
DOE Laboratories and Field Facilities $\ldots \ldots \ldots \ldots \ldots \ldots \ldots \ldots \ldots \ldots \ldots \ldots$

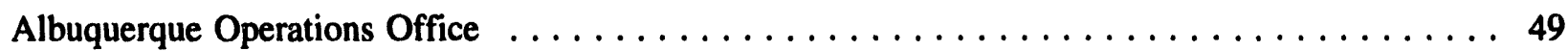

Los Alamos National Laboratory $\ldots \ldots \ldots \ldots \ldots \ldots \ldots \ldots \ldots \ldots \ldots$

Sandia National Laboratories $\ldots \ldots \ldots \ldots \ldots \ldots \ldots \ldots \ldots \ldots \ldots \ldots$

Bartlesville Project Office $\ldots \ldots \ldots \ldots \ldots \ldots \ldots \ldots \ldots \ldots \ldots \ldots$

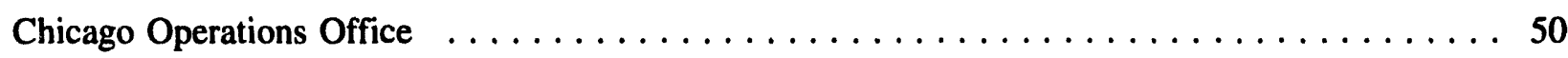

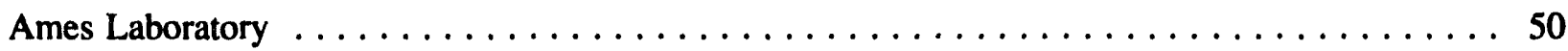

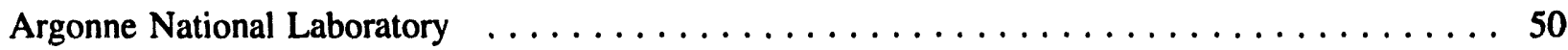

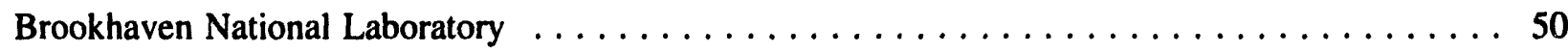

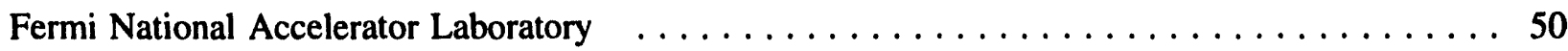

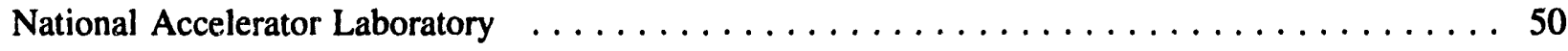

Princeton Plasma Physics Laboratory $\ldots \ldots \ldots \ldots \ldots \ldots \ldots \ldots \ldots \ldots \ldots \ldots \ldots \ldots$

Environmental Measurements Laboratory $\ldots \ldots \ldots \ldots \ldots \ldots \ldots \ldots \ldots \ldots \ldots \ldots$

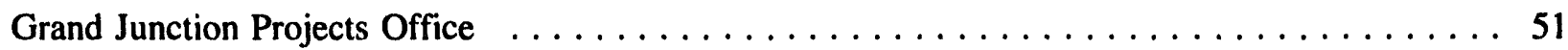

Idaho Field Office $\ldots \ldots \ldots \ldots \ldots \ldots \ldots \ldots \ldots \ldots \ldots \ldots \ldots \ldots \ldots \ldots \ldots$

Laramie Project Office $\ldots \ldots \ldots \ldots \ldots \ldots \ldots \ldots \ldots \ldots \ldots \ldots \ldots \ldots \ldots \ldots$

Morgantown Energy Technology Center $\ldots \ldots \ldots \ldots \ldots \ldots \ldots \ldots \ldots \ldots \ldots$

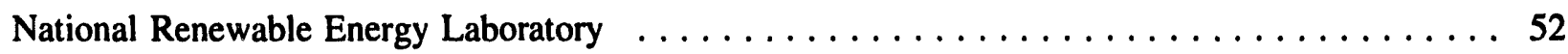

Naval Petroleum and Oil Shale Reserves in Colorado, Utah,

Naval Petroleum Reserves in California $\ldots \ldots \ldots \ldots \ldots \ldots \ldots \ldots \ldots \ldots \ldots$

Nevada Field Office $\quad \ldots \ldots \ldots \ldots \ldots \ldots \ldots \ldots \ldots \ldots \ldots \ldots \ldots \ldots \ldots \ldots$

Oak Ridge National Laboratory $\ldots \ldots \ldots \ldots \ldots \ldots \ldots \ldots \ldots \ldots \ldots \ldots \ldots \ldots$

Oak Ridge Operations Office $\ldots \ldots \ldots \ldots \ldots \ldots \ldots \ldots \ldots \ldots \ldots \ldots \ldots \ldots \ldots$ 


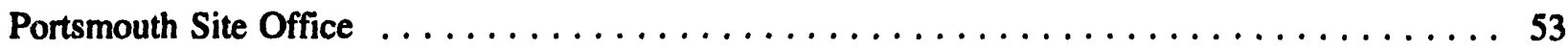

Pittsburgh Energy Technology Center $\ldots \ldots \ldots \ldots \ldots \ldots \ldots \ldots \ldots \ldots \ldots \ldots \ldots \ldots$

Pittsburgh Naval Reactors Office $\ldots \ldots \ldots \ldots \ldots \ldots \ldots \ldots \ldots \ldots \ldots \ldots \ldots$

Westinghouse Electric Corporation $\ldots \ldots \ldots \ldots \ldots \ldots \ldots \ldots \ldots \ldots \ldots \ldots$

Richland Field Office $\ldots \ldots \ldots \ldots \ldots \ldots \ldots \ldots \ldots \ldots \ldots \ldots \ldots, 54$

Battelle Pacific Northwest Laboratory $\ldots \ldots \ldots \ldots \ldots \ldots \ldots \ldots \ldots \ldots \ldots \ldots$

Hanford Environmental Health Foundation $\ldots \ldots \ldots \ldots \ldots \ldots \ldots \ldots \ldots \ldots \ldots$

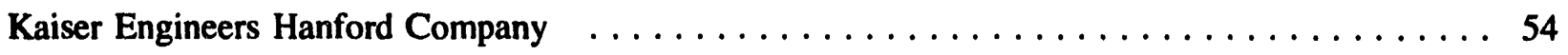

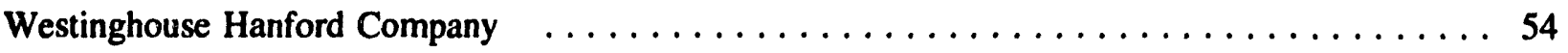

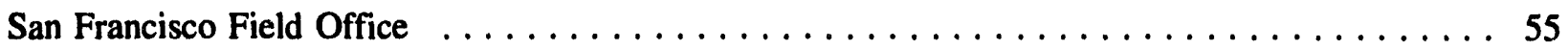

Lawrence Berkeley Laboratory $\ldots \ldots \ldots \ldots \ldots \ldots \ldots \ldots \ldots \ldots \ldots \ldots$

Lawrence Livermore National Laboratory $\ldots \ldots \ldots \ldots \ldots \ldots \ldots \ldots \ldots \ldots$

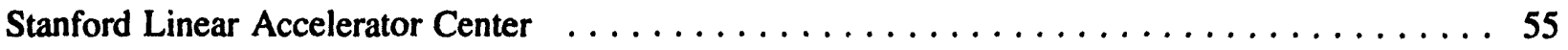

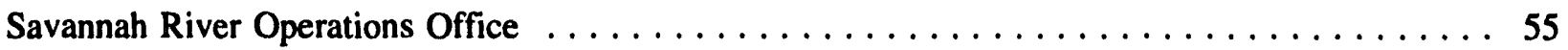

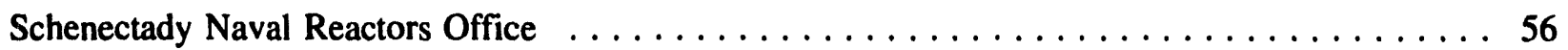

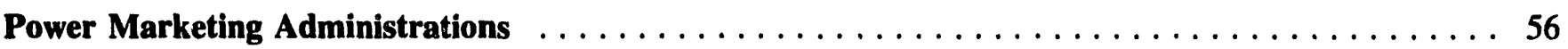

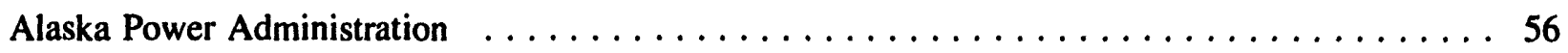

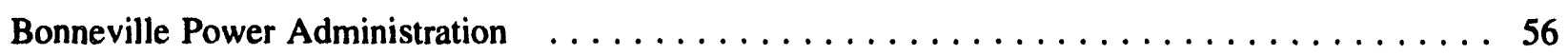

Southeastern Power Administration $\ldots \ldots \ldots \ldots \ldots \ldots \ldots \ldots \ldots \ldots \ldots \ldots$

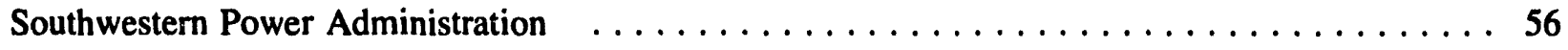

Western Area Power Administration $\ldots \ldots \ldots \ldots \ldots \ldots \ldots \ldots \ldots \ldots \ldots \ldots$

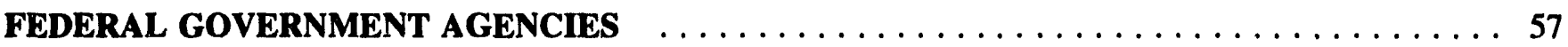

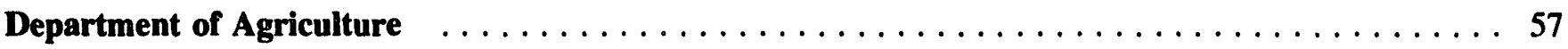

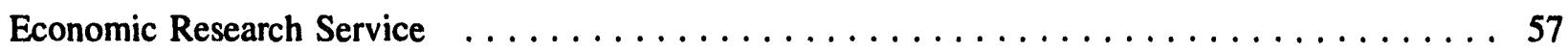

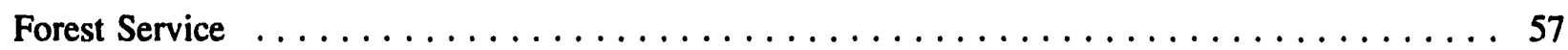




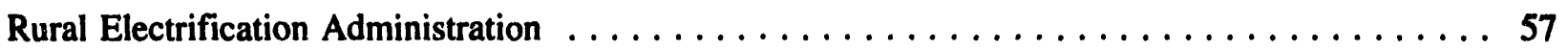

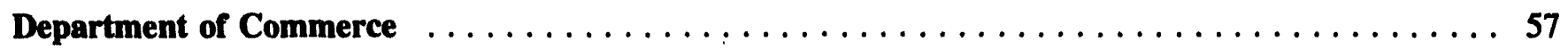

Bureau of Census $\ldots \ldots \ldots \ldots \ldots \ldots \ldots \ldots \ldots \ldots \ldots \ldots \ldots \ldots \ldots \ldots$

Bureau of Economic Analysis $\ldots \ldots \ldots \ldots \ldots \ldots \ldots \ldots \ldots \ldots \ldots \ldots \ldots$

Import Administration $\ldots \ldots \ldots \ldots \ldots \ldots \ldots \ldots \ldots \ldots \ldots \ldots \ldots \ldots \ldots \ldots$

International Trade Administration $\ldots \ldots \ldots \ldots \ldots \ldots \ldots \ldots \ldots \ldots \ldots \ldots \ldots$

Office of Energy, Environment, and Infrastructure $\ldots \ldots \ldots \ldots \ldots \ldots \ldots \ldots \ldots$

National Institute of Standards and Technology $\ldots \ldots \ldots \ldots \ldots \ldots \ldots \ldots \ldots$

National Oceanic and Atmospheric Administration $\ldots \ldots \ldots \ldots \ldots \ldots \ldots \ldots$

National Technical Information Service $\ldots \ldots \ldots \ldots \ldots \ldots \ldots \ldots \ldots \ldots \ldots$

Department of Defense $\ldots \ldots \ldots \ldots \ldots \ldots \ldots \ldots \ldots \ldots \ldots \ldots \ldots \ldots \ldots$

Office of Assistant Secretary for Defense for Production and Logistics $\ldots \ldots \ldots \ldots \ldots$

Department of Health and Human Services $\ldots \ldots \ldots \ldots \ldots \ldots \ldots \ldots \ldots \ldots \ldots$

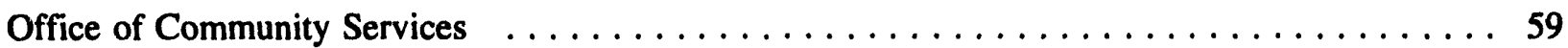

Department of Housing and Urban Development $\ldots \ldots \ldots \ldots \ldots \ldots \ldots \ldots \ldots$

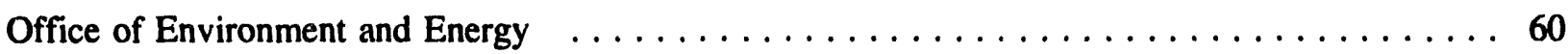

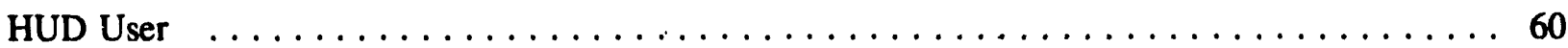

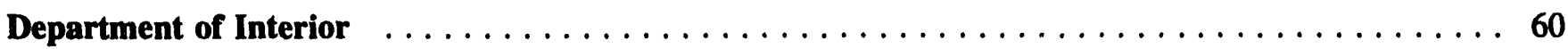

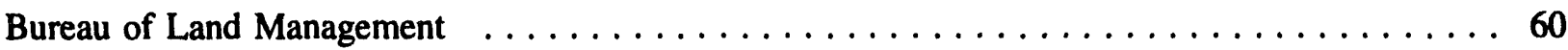

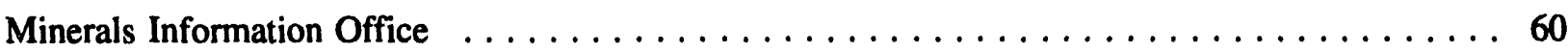

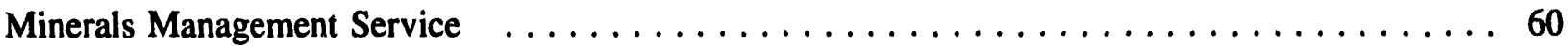

Office of Surface Mining Reclamation and Enforcement $\ldots \ldots \ldots \ldots \ldots \ldots \ldots \ldots$

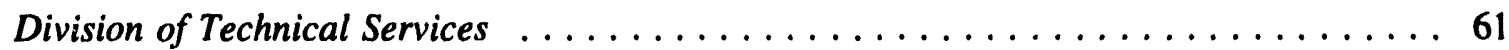

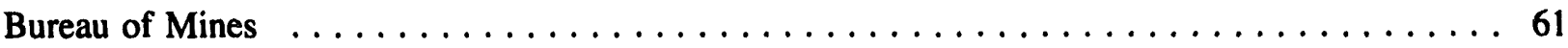

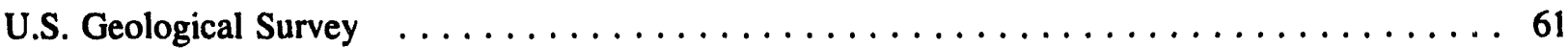




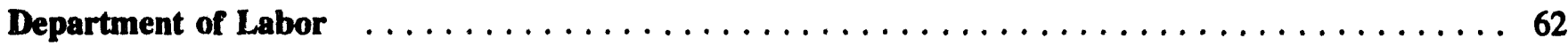

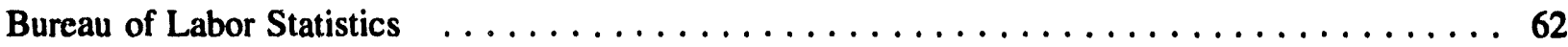

Division of Monthly Industry Employment Statistics $\ldots \ldots \ldots \ldots \ldots \ldots \ldots$

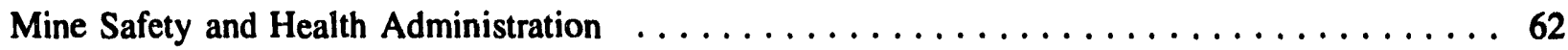

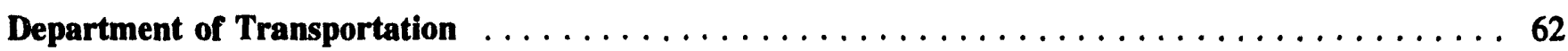

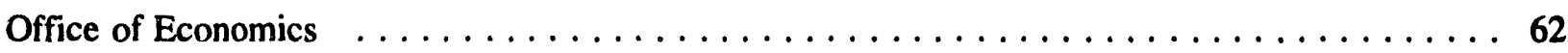

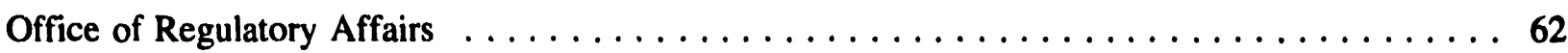

Federal Highway Administration $\ldots \ldots \ldots \ldots \ldots \ldots \ldots \ldots \ldots \ldots \ldots \ldots \ldots \ldots \ldots \ldots$

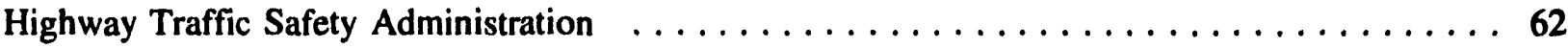

Office of Technology Sharing, DTS-31 $\ldots \ldots \ldots \ldots \ldots \ldots \ldots \ldots \ldots \ldots \ldots \ldots \ldots$

Research and Special Programs Administration $\ldots \ldots \ldots \ldots \ldots \ldots \ldots \ldots \ldots \ldots \ldots \ldots \ldots$

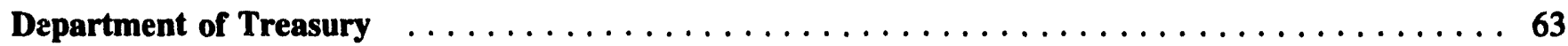

Bureau of Alcohol, Tobacco, and Firearms $\ldots \ldots \ldots \ldots \ldots \ldots \ldots$

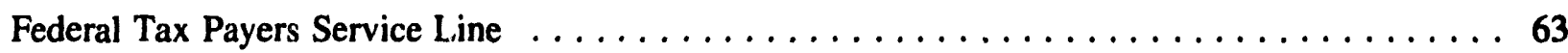

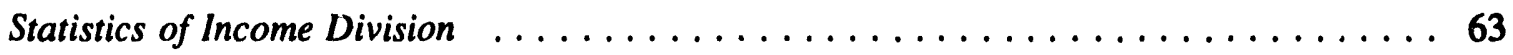

FEDERAL GOVERNMENT LEGISLATIVE BRANCH $\ldots \ldots \ldots \ldots \ldots \ldots$

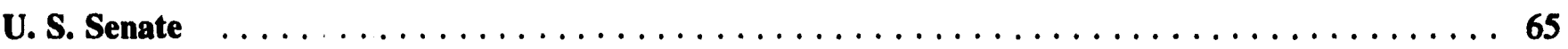

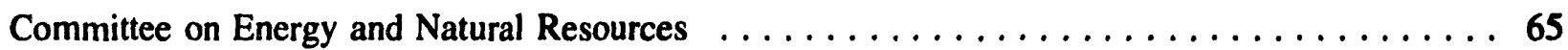

Subcommittee on Energy Regulation and Conservation $\ldots \ldots \ldots \ldots \ldots \ldots \ldots \ldots$

Subcommittee on Energy Research and Development $\ldots \ldots \ldots \ldots \ldots$

Subcommittee on Mineral Resources Development and Production $\ldots \ldots \ldots \ldots \ldots$

Subcommittee on Public Lands, Natural Parks and Forests $\ldots \ldots \ldots \ldots 6$

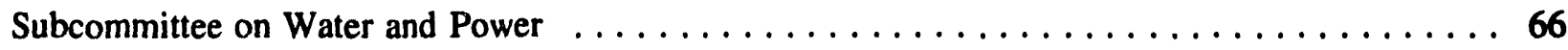

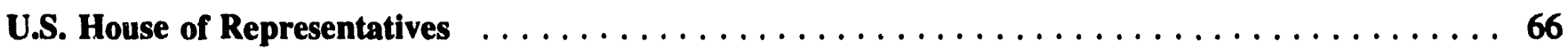

Committee on Energy and Commerce $\ldots \ldots \ldots \ldots \ldots \ldots \ldots \ldots \ldots \ldots \ldots \ldots \ldots \ldots \ldots \ldots \ldots \ldots$ 


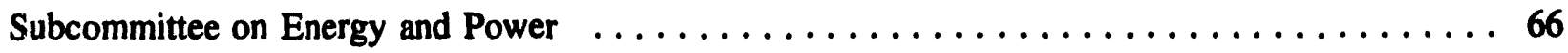

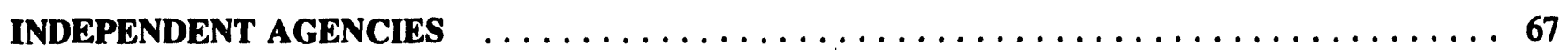

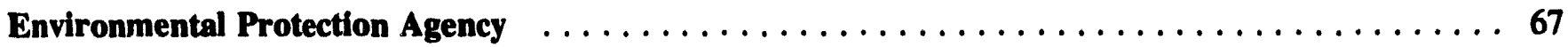

Indoor Air Quality Information Clearinghouse $\ldots \ldots \ldots \ldots \ldots \ldots \ldots \ldots \ldots \ldots \ldots \ldots \ldots \ldots$

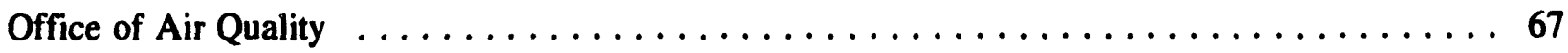

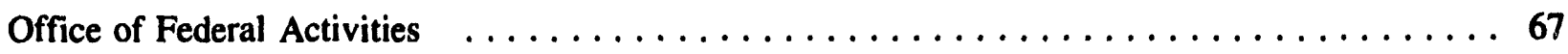

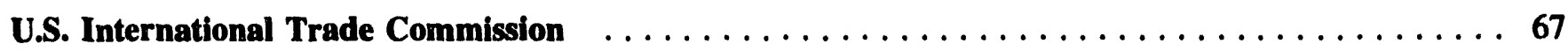

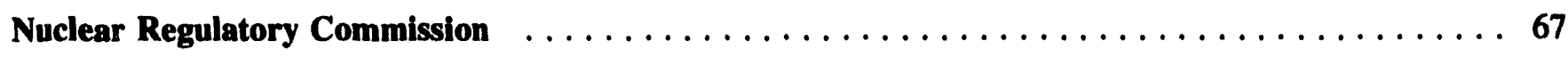

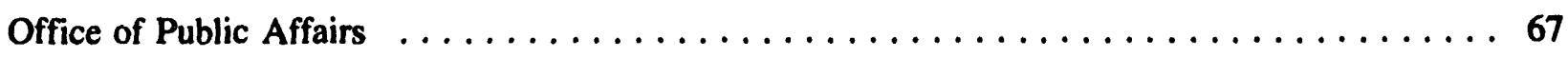

Tennessee Valley Authority $\ldots \ldots \ldots \ldots \ldots \ldots \ldots \ldots \ldots \ldots \ldots \ldots \ldots \ldots \ldots$

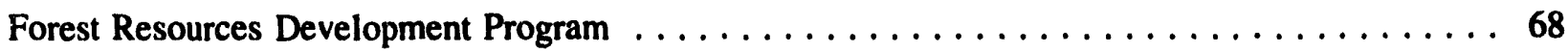

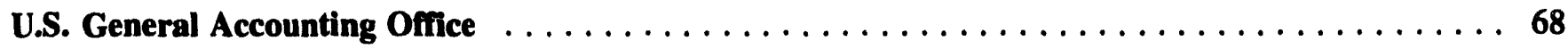

U.S. Government Printing Office $\ldots \ldots \ldots \ldots \ldots \ldots \ldots \ldots \ldots \ldots \ldots \ldots \ldots \ldots \ldots$

STATE GOVERNOR OFFICES, STATE ENERGY OFFICES, STATE OIL AND GAS AGENCIES, STATE GEOLOGISTS, AND PUBLIC SERVICE COMMISSIONS $\ldots \ldots 71$

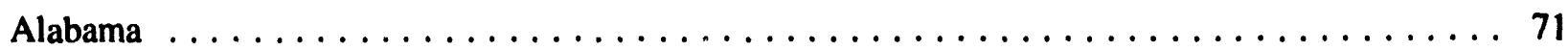

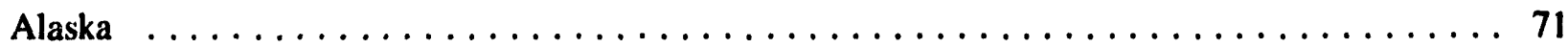

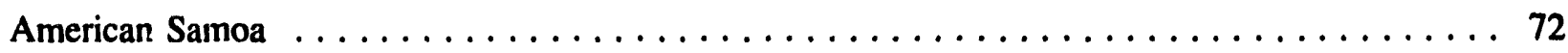

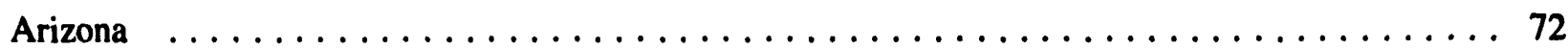

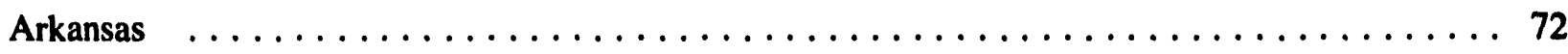

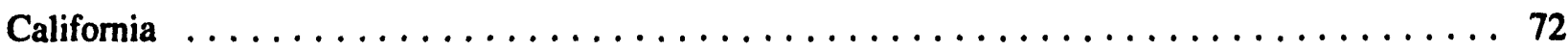

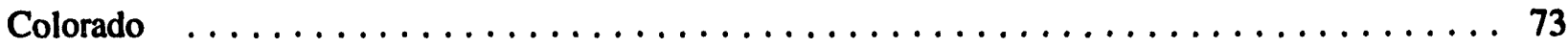

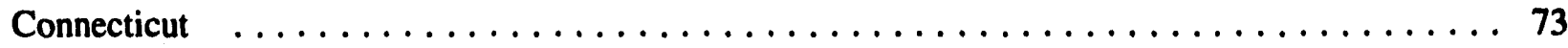

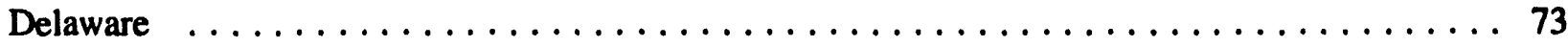

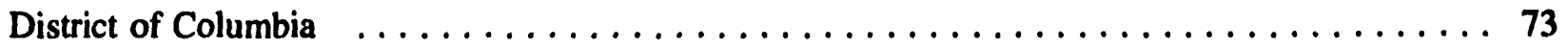

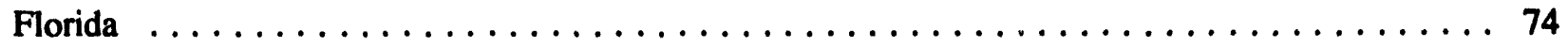


Georgia $\ldots \ldots \ldots \ldots \ldots \ldots \ldots \ldots \ldots \ldots \ldots \ldots \ldots \ldots \ldots \ldots \ldots \ldots \ldots \ldots \ldots$

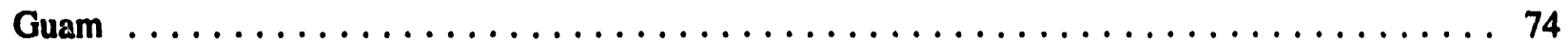

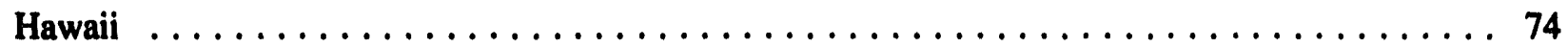

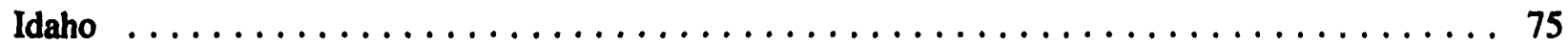

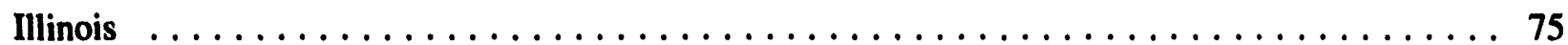

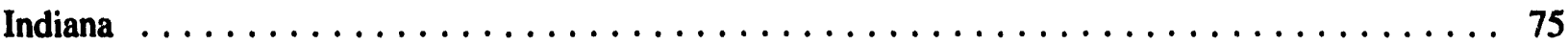

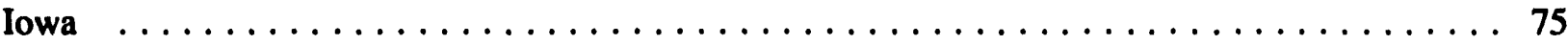

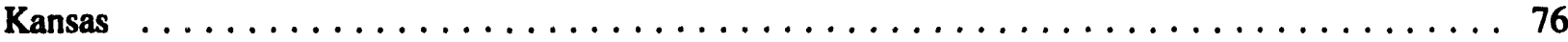

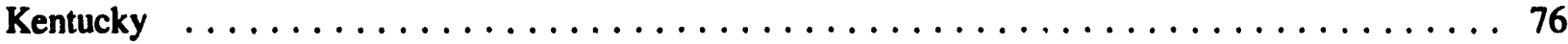

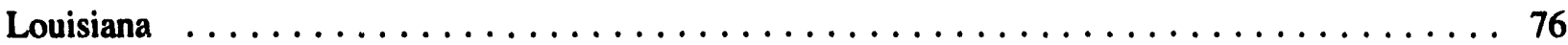

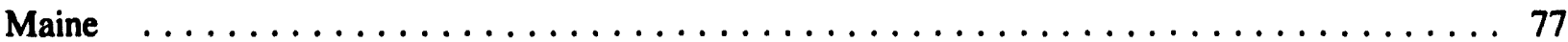

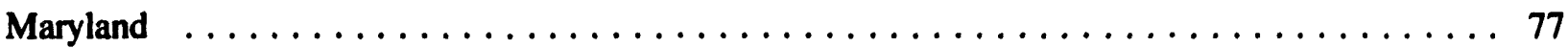

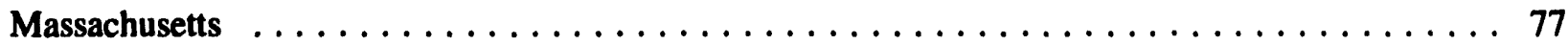

Michigan $\ldots \ldots \ldots \ldots \ldots \ldots \ldots \ldots \ldots \ldots \ldots \ldots \ldots \ldots \ldots \ldots \ldots \ldots$

Minnesota $\quad \ldots \ldots \ldots \ldots \ldots \ldots \ldots \ldots \ldots \ldots \ldots \ldots \ldots \ldots \ldots \ldots \ldots \ldots \ldots$

Mississippi $\ldots \ldots \ldots \ldots \ldots \ldots \ldots \ldots \ldots \ldots \ldots \ldots \ldots \ldots \ldots \ldots \ldots \ldots \ldots \ldots$

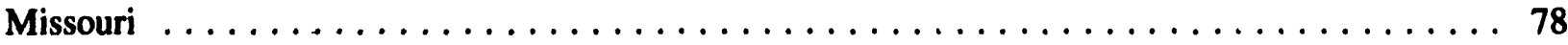

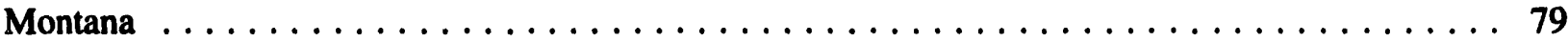

Nebraska $\ldots \ldots \ldots \ldots \ldots \ldots \ldots \ldots \ldots \ldots \ldots \ldots \ldots \ldots \ldots \ldots \ldots \ldots \ldots$

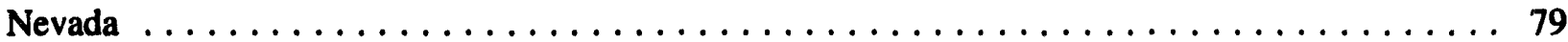

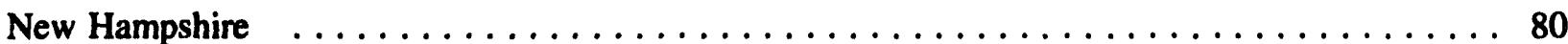

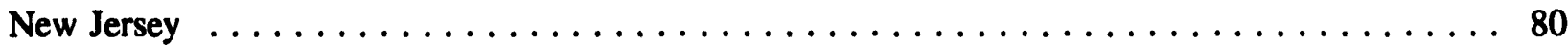

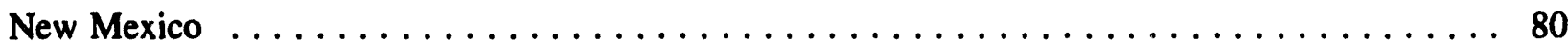

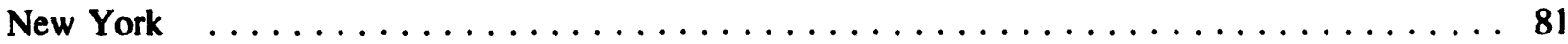

North Carolina $\ldots \ldots \ldots \ldots \ldots \ldots \ldots \ldots \ldots \ldots \ldots \ldots \ldots \ldots \ldots \ldots \ldots \ldots \ldots$ 


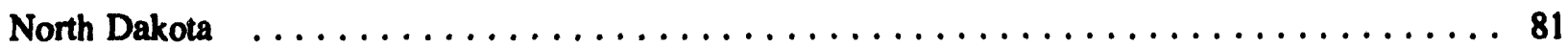

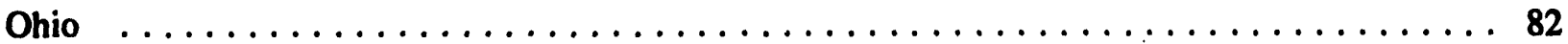

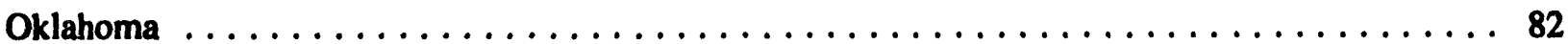

Oregon $\ldots \ldots \ldots \ldots \ldots \ldots \ldots \ldots \ldots \ldots \ldots \ldots \ldots \ldots \ldots \ldots \ldots \ldots \ldots \ldots \ldots \ldots$

Pennsylvania $\ldots \ldots \ldots \ldots \ldots \ldots \ldots \ldots \ldots \ldots \ldots \ldots \ldots \ldots \ldots \ldots \ldots \ldots \ldots$

Puerto Rico $\ldots \ldots \ldots \ldots \ldots \ldots \ldots \ldots \ldots \ldots \ldots \ldots \ldots \ldots \ldots \ldots \ldots \ldots \ldots$

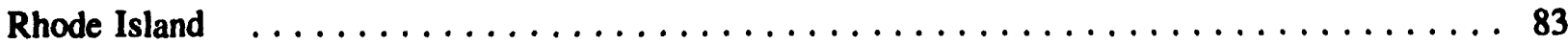

South Carolina $\ldots \ldots \ldots \ldots \ldots \ldots \ldots \ldots \ldots \ldots \ldots \ldots \ldots \ldots \ldots \ldots \ldots$

South Dakota $\ldots \ldots \ldots \ldots \ldots \ldots \ldots \ldots \ldots \ldots \ldots \ldots \ldots \ldots \ldots \ldots \ldots \ldots$

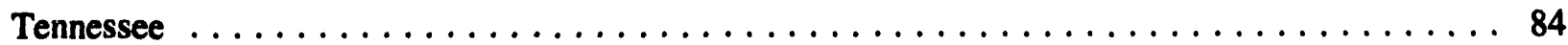

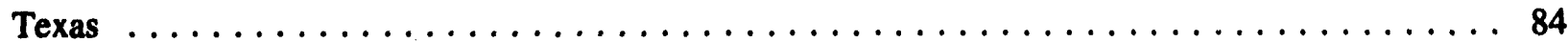

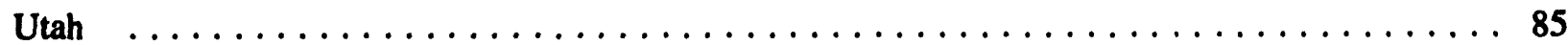

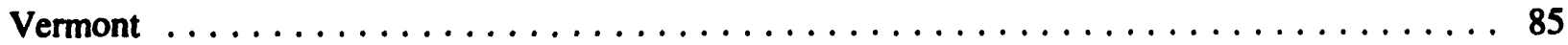

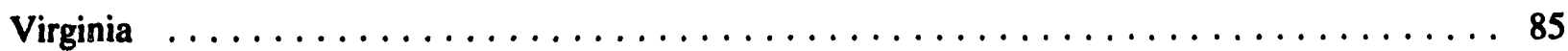

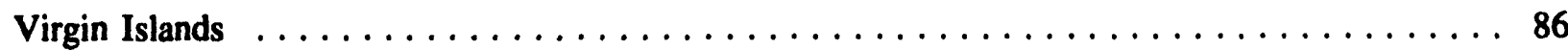

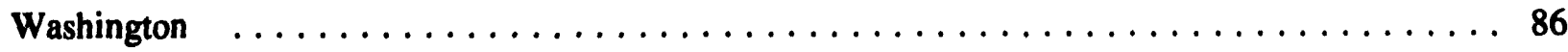

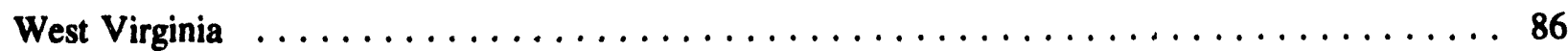

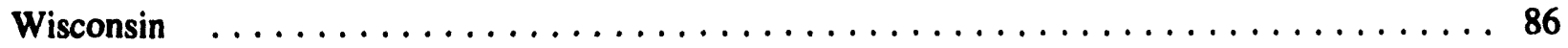

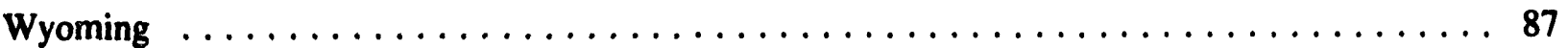

TRADE ASSOCIATIONS $\ldots \ldots \ldots \ldots \ldots \ldots \ldots \ldots \ldots \ldots \ldots \ldots$

Air Conditioning Contractors of America $\ldots \ldots \ldots \ldots \ldots \ldots \ldots \ldots \ldots$

Air Transport Association of America $\ldots \ldots \ldots \ldots \ldots \ldots \ldots$

Aircraft Owners and Pilots Association $\ldots \ldots \ldots \ldots \ldots \ldots \ldots \ldots$

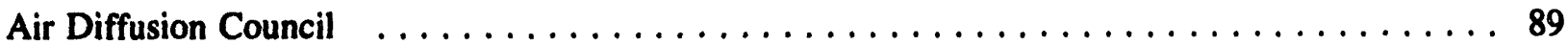

American Architectural Manufacturers Association $\ldots \ldots \ldots \ldots \ldots \ldots$ 
American Boiler Manufacturers Association $\ldots \ldots \ldots \ldots \ldots \ldots$

American Coal Ash Association $\ldots \ldots \ldots \ldots \ldots \ldots \ldots \ldots \ldots \ldots \ldots \ldots \ldots \ldots$

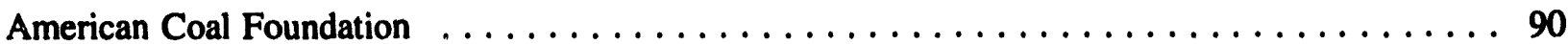

American College of Nuclear Physicians $\ldots \ldots \ldots \ldots \ldots \ldots \ldots \ldots \ldots \ldots$

American Consulting Engineers Council $\ldots \ldots \ldots \ldots \ldots \ldots \ldots \ldots \ldots \ldots$

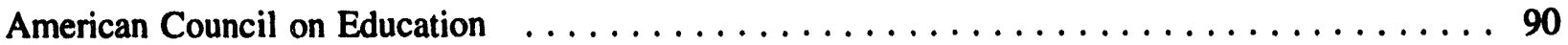

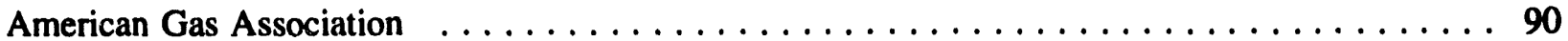

American Iron and Steel Institute $\ldots \ldots \ldots \ldots \ldots \ldots \ldots \ldots \ldots \ldots \ldots \ldots \ldots \ldots$

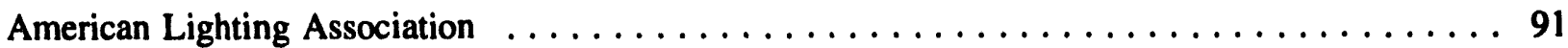

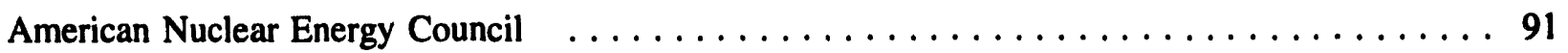

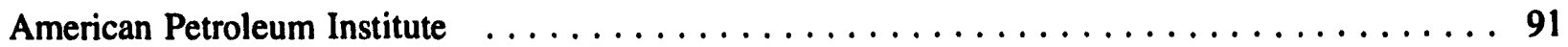

American Plywood Association $\ldots \ldots \ldots \ldots \ldots \ldots \ldots \ldots \ldots \ldots \ldots \ldots \ldots \ldots$

American Public Power Association $\ldots \ldots \ldots \ldots \ldots \ldots \ldots \ldots \ldots \ldots \ldots \ldots \ldots$

American Society for Engineering Education $\ldots \ldots \ldots \ldots \ldots \ldots \ldots \ldots \ldots \ldots$

American Society for Testing and Materials $\ldots \ldots \ldots \ldots \ldots \ldots \ldots \ldots \ldots \ldots \ldots \ldots$

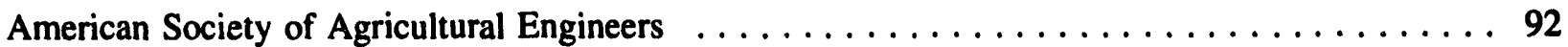

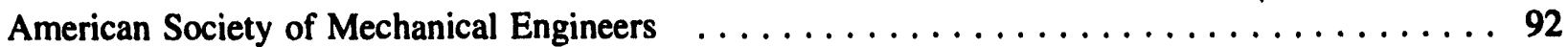

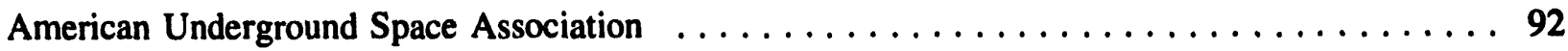

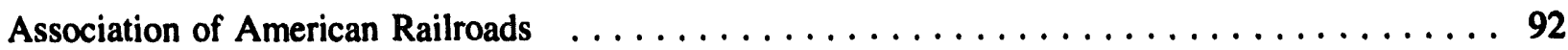

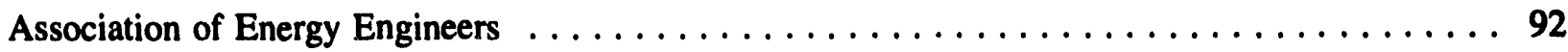

Association of Home Appliance Manufacturers $\ldots \ldots \ldots \ldots \ldots \ldots \ldots \ldots \ldots \ldots$

Association of Pellet Fuel Industries $\ldots \ldots \ldots \ldots \ldots \ldots \ldots \ldots \ldots \ldots \ldots \ldots \ldots$

Biomass Energy Research Association $\ldots \ldots \ldots \ldots \ldots \ldots \ldots \ldots \ldots \ldots \ldots \ldots \ldots \ldots$

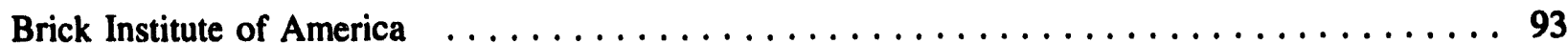

Ceilings and Interior Systems Construction Association $\ldots \ldots \ldots \ldots \ldots$ 
Consumer Energy Council of American Research Foundation $\ldots \ldots \ldots \ldots \ldots$

Cooling Tower Institute $\ldots \ldots \ldots \ldots \ldots \ldots \ldots \ldots \ldots \ldots \ldots \ldots \ldots \ldots \ldots$

Copper Development Association, Inc. $\ldots \ldots \ldots \ldots \ldots \ldots \ldots \ldots \ldots \ldots \ldots \ldots \ldots$

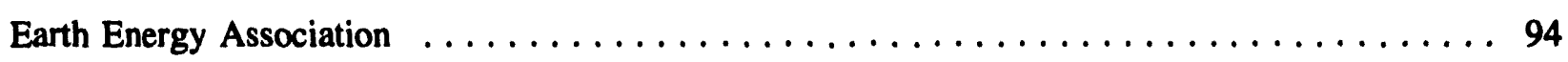

Eastern Region Coalbed Methane Information Center $\ldots \ldots \ldots \ldots \ldots \ldots$

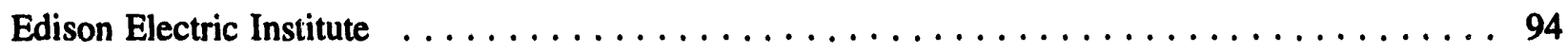

Electrical Generating Systems Association $\ldots \ldots \ldots \ldots \ldots \ldots \ldots \ldots \ldots \ldots \ldots \ldots \ldots$

Electricity Consumers Resource Council $\ldots \ldots \ldots \ldots \ldots \ldots \ldots \ldots \ldots \ldots \ldots \ldots \ldots \ldots \ldots$

Florida Solar Energy Industries Association $\ldots \ldots \ldots \ldots \ldots \ldots \ldots \ldots$

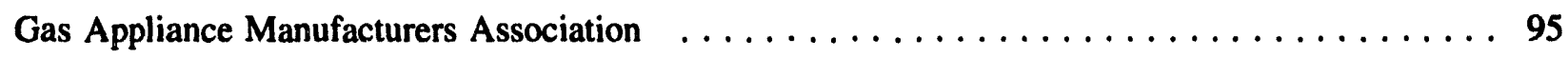

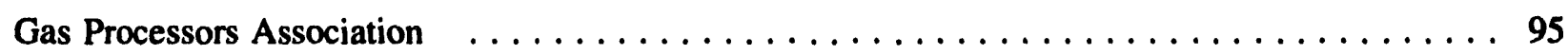

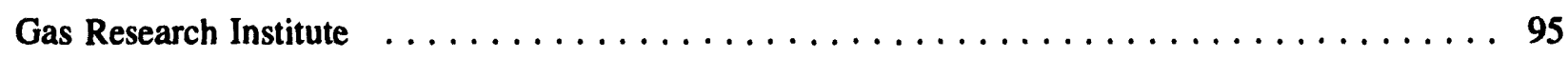

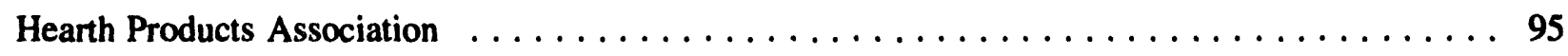

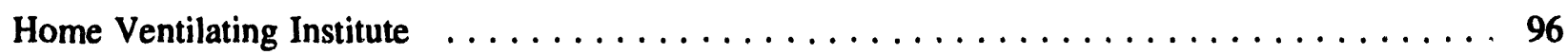

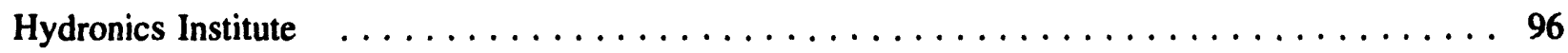

Illuminating Engineering Society of North America $\ldots \ldots \ldots \ldots \ldots \ldots$

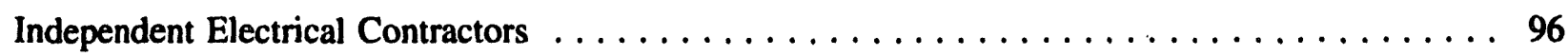

Independent Liquid Terminals Association $\ldots \ldots \ldots \ldots \ldots \ldots \ldots \ldots \ldots \ldots \ldots \ldots \ldots \ldots \ldots$

Independent Lubricant Manufacturers Association $\ldots \ldots \ldots \ldots \ldots \ldots \ldots$

Independent Petroleum Association of America $\ldots \ldots \ldots \ldots \ldots \ldots \ldots \ldots \ldots \ldots \ldots$

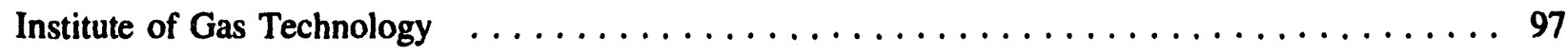

International Association of Drilling Contractors $\ldots \ldots \ldots \ldots \ldots \ldots \ldots \ldots$

Interstate Naturat Gas Association of America $\ldots \ldots \ldots \ldots \ldots \ldots \ldots$

National Association of Energy Service Companies $\ldots \ldots \ldots \ldots \ldots \ldots \ldots$

National Association of Power Engineers $\ldots \ldots \ldots \ldots \ldots \ldots \ldots \ldots \ldots \ldots \ldots$ 
National Association of State Utility Consumer Advocates $\ldots \ldots \ldots \ldots \ldots \ldots$

National Coal Association $\ldots \ldots \ldots \ldots \ldots \ldots \ldots \ldots \ldots \ldots \ldots \ldots \ldots \ldots$

National Electrical Contractors Association, Inc. $\ldots \ldots \ldots \ldots \ldots \ldots \ldots$

National Electrical Manufacturers Association $\ldots \ldots \ldots \ldots \ldots \ldots \ldots \ldots$

National Hydropower Association $\ldots \ldots \ldots \ldots \ldots \ldots \ldots \ldots \ldots \ldots \ldots \ldots$

National Lubricating Grease Institute $\ldots \ldots \ldots \ldots \ldots \ldots \ldots \ldots \ldots \ldots \ldots$

National Rural Electric Cooperative Association $\ldots \ldots \ldots \ldots \ldots \ldots \ldots \ldots$

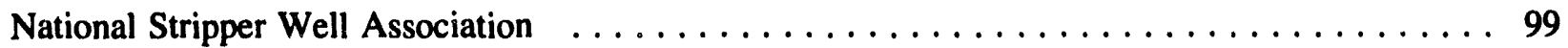

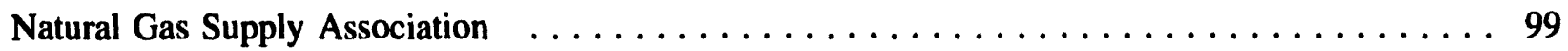

Natural Gas Supply Information Center $\ldots \ldots \ldots \ldots \ldots \ldots \ldots \ldots \ldots$

North American Electric Reliability Council $\ldots \ldots \ldots \ldots \ldots \ldots \ldots$

Petroleum Marketers Association of America $\ldots \ldots \ldots \ldots \ldots \ldots \ldots \ldots \ldots \ldots \ldots \ldots \ldots \ldots$

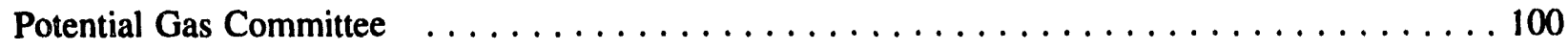

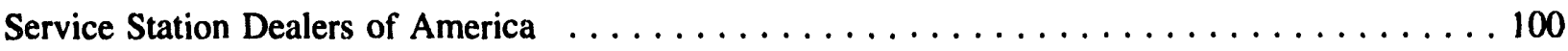

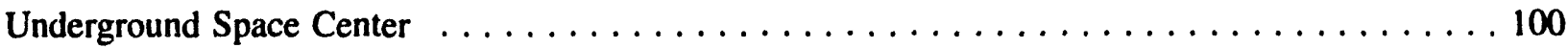

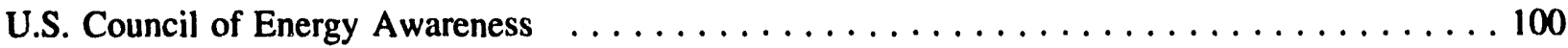

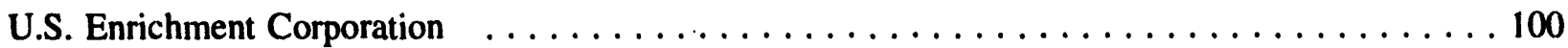




\section{Information Centers}

\section{Conservation and Renewable Energy Inquiry and Referral Service (CAREIRS) \\ P. O. Box 8900 \\ Silver Spring, MD 20907 \\ (800) 523-2929 (Continental United States) \\ (800) 233-3071 (Alaska and Hawaii)}

Provides information on the full spectrum of renewable energy technologies and energy conservation, including active/passive solar, solar thermal, photovoltaics, wind, biomass, alcohol fuel, hydroelectric, geothermal, and ocean thermal energy. CAREIRS also maintains contact with a nationwide network of public and private organizations that specialize in highly technical or regionally specific information. CAREIRS is the successor to the National Solar Heating and Cooling Information Center.

\section{Energy Science and Technology Software Center (ESTSC) \\ Edwin Kiad, Director \\ P.O. Box 1020 \\ Oak Ridge, TN 37831 \\ Fax: (615) 576-2865 \\ General Information (615) 576-2606}

Operated under contract for DOE's Office of Scientific and Technical Information, the Energy Science and Technology Software Center (ESTSC) is DOE's centralized software management center. In addition to housing a collection of software developed by DOE and contractors, ESTSC maintains software developed for the U.S. Nuclear Regulatory Commission and exchanges software related to nuclear science and technology with the International Nuclear Energy Agency in France. ESTSC collects, prepares, and sells scientific and technical copyrighted computer software to the DOE community, other government organizations, universities, and the public, as appropriate; checks for package completeness; executes test cases, as requested; provides assistance and consultation on software implementation; and publishes descriptions of new and updated software packages for usens.

\author{
3 National Appropriate Technology \\ Assistance Service (NATAS) \\ George Everett, Senior Information \\ Specialist \\ P.O. Box 2525 \\ Butte, MT 59702-2525 \\ (800) 428-2525 \\ (800) 428-1718 (Montana only)
}

Provides tailored information responses, engineering/scientific technical assistance, and business assistance to help Americans implement energy-saving appropriate technologies. NATAS provides more detailed technical assistance than other programs and helps entrepreneurs develop appropriate technology.

\section{National Energy Information Center (NEIC) EI-231, Room 1F-048, Forrestal (202) $586-8800$ \\ TTY: (202) 586-1181 \\ Fax: (202) 586-0727}

Provides statistical and analytical energy data, information, and referral assistance to the government and private sectors, academia, and the public. NEIC distributes EIA publications to the media, public libraries, Federal, State, and local governments, and EIA survey respondents. NEIC also provides Government Printing Office (GPO) ordering information. Single copies of blank data collection forms, directories, and EIA press releases are free of charge to all users. Ordering information on EIA machine-readable files available through the National Technical Information Service (NTIS) and the Government Printing Office may be obtained from NEIC.

\section{NEIC Subject Specialists}

Coal

Dorothy Karsteter

Bill Horvath

Electric and Nuclear Power

Thomas Welch

William Jeffers 
Media/Press Inquiries

Thomas Welch

Jonathan Cogan

Natural Gas

Paula Altman

Jonathan Cogan

Petroleum

Leola Withrow

Trisha Christian

Renewable Energy Resources/Conservation

Marion King

Karen Freedman

Data Survey Forms

Single Copy Distribution

Karen Freedman

Information About Obtaining Machine-Readable Modeling Tapes, Data Files, and Diskettes

(202) $586-8800$

Information About Obtaining Microfiche of Publications (202) 586-8800

\section{National Institute for Petroleum and Energy Research (NIPER) \\ Bill Linville, Oil Editor \\ P.O. Box 2128 \\ Bartlesville, OK 74005 \\ (918) 337-4375}

Conducts research, development, and demonstration efforts covering all phases of liquid fossil fuel technology. Includes research on petroleum extraction using enhanced oil recovery methods and improved drilling technology; the extraction of natural gas from Western tight sands processing and thermodynamic properties of conventional oils, as well as liquid products made from coal, oil shale, and tar sands; recycling of waste lubricating oil; and improving automotive engine emissions. A data bank on crude oil recovery is available to the public. Effective October 1, 1983, the Bar- tlesville Energy Technology Center was transferred for operation by the Illinois Institute of Technology Research and was renamed the National Institute for Petroleum and Energy Research. In addition, NIPER will solicit research from the private sector as well as from other Government agencies.

\section{6}

Office of Scientific and Technical
Information (OSTI)
Elizabeth V. Buffum, Director
Department of Energy
P. O. Box 62
Oak Ridge, TN 37831
(615) 576-2865
Fax: (615) $576-2865$

Provides direction and leadership for the Departmentwide Scientific and Technical Information Program, which serves the information needs of DOE and contractor facilities. OSTI collects, processes, and disseminates information resulting from DOE research projects, as well as worldwide information on subjects of interest to DOE researchers; serves as the central processing and distribution point and repository for DOE scientific and technical reports; and develops data bases to provide access to energy literature, DOE research in progress, and DOE-developed software. OSTI also maintains a registry of energy publications produced by the Department for the public; develops specialized information systems and products in response to the needs of DOE program managers; represents DOE in international technical information exchanges, for example with the International Energy Agency, the International Atomic Energy Agency, and bilateral; and provides energy information to the public through the National Technical Information Service.

General Information

(615) 576-4463

Technical Reports

(615) 576-8401

Data Bases

(615) 576-1175 


\section{Department of Energy/Washington}

\section{Departmental Advisory Committees}

\author{
7 American Statistical Association \\ Committee on Energy Statistics (ASA) \\ Renee Miller \\ EI-72, Room 307, H Street \\ (202) 254-5507
}

Originally chartered on October 17,1984, to utilize the expertise of ASA for review of elements of EIA information collection and analysis programs; to advise on technical and methodological issues in the planning, operation, and review of EIA statistical programs; and to advise on matters concerning improved energy modeling and forecasting tools. The charter has been renewed every two years since 1984; the most recent approval for renewal was received on October 2, 1992.

\section{Environmental Restoration and Waste Management Advisory Committee (EMAC) \\ James T. Melillo, Executive Secretary EM-1, Room 5B-151, Forrestal (202) $586-4400$}

Established on January 15, 1992, to provide to the Assistant Secretary of Environmental Restoration and Waste Management (EM) information, advice, and recommendations concerning the content and process of the Programmatic Environmental Impact Statement (PEIS) and other EM projects. EMAC advises the Assistant Secretary on both the substance and the process of PEIS from the perspective of affected groups and State and local governments. EMAC also advises on any other EM projects which the Assistant Secretary requests and assigns to the Committee for review. The Committee helps to improve the Environmental Restoration and Waste Management Program by assisting in the process of securing consensus recommendations and providing the Department's customers with opportunities to make their views known.
9

\author{
Basic Energy Sciences Advisory \\ Committee (BESAC) \\ Diane Stull \\ ER-10, Room J-304, Germantown \\ (301) 903-5565
}

Established on October 16, 1986, to provide advice to the Secretary of Energy, through the Director of Energy Research, on elements of the Department's Basic Energy Sciences (BES) Program, including advice on long-range plans, priorities, and strategies to address more effectively the scientific aspects of basic energy sciences issues of DOE policies and programs. The Committee will provide recommendations on appropriate levels of funding to develop those plans, priorities, and strategies, and to help maintain appropriate balance between competing elements of the BES program and on scientific aspects of basic energy sciences issues of concern to DOE.

\section{Health and Environmental Research Advisory Committee (HERAC) Elsie L. Patterson ER-70, Room J-104, Germantown (301) $903-2987$}

Established on November 22, 1983, to conduct periodic reviews of elements of the Health and Environmental Research Program and provide advice on long-range plans, priorities, and strategies to address more effectively the scientific aspects of energy-related health and environmental issues of departmental policies and programs. To provide advice on appropriate levels of funding to develop those plans, priorities, and strategies and to help maintain appropriate balance between competing elements of the program. 


\section{High Energy Physics Advisory Panel (HEPAP) \\ Marsha Marsden \\ ER-222, Room F-336, Germantown \\ (301) $903-4140$}

Established on January 13,1967, to provide advice and guidance on a continuing basis to the Secretary of Energy, through the Director of Energy Research, on the national high energy physics research program which encompasses the Superconducting Super Collider activities. HEPAP activities include: (a) periodic reviews of the program and recommendation of any changes considered desirable on the basis of scientific and technological advances or other factors; (b) advice on long-range plans, priorities, and strategies for the national high energy physics program; (c) advice on recommended appropriate levels of funding to assure a world leadership position and helping maintain appropriate balance between competing elements of the program; and (d) advice and guidance on any issues relating to the program as requested by the Secretary of Energy or the Director of Energy Research.

\section{National Coal Council (NCC) \\ Margie Biggerstaff \\ FE-5, Room 4G-055, Forrestal \\ (202) 586-3867}

The National Coal Council was established by the Secretary of Energy on October 25, 1984, and was chartered in accordance with the Federal Advisory Committee Act. The duties of the NCC are solely advisory. Its purpose is to provide advice and recommendations on a continuing basis as requested by the Secretary of Energy on general policy matters relating to coal matters.

\section{National Petroleum Council (NPC) \\ Margie Biggerstaff \\ FE-5, Room 4G-055, Forrestal \\ (202) 586-3867}

Established by the Secretary of Interior on May 3,1946, at the request of President Harry S. Truman. In 1977, the NPC's functions were transferred to DOE. It is chartered under the provisions of the Federal Advisory Committee Act. The duties of the NPC are solely advisory. Its purpose is to inform and make recommendations to the Secretary of Energy with respect to any matter relating to oil and gas or the oil and gas industry.

\section{Secretary of Energy Advisory Board (SEAB) \\ Jake W. Stewart, Jr. \\ HR-2, Room 7B-198, Forrestal \\ (202) 586-7092}

Established on January 2,1990, to advise the Secretary of Energy on the research, development, energy, and national defense responsibilities, activities, and operations of DOE and to provide expert guidance to DOE in these areas.

\section{OFFICE OF THE ASSISTANT SECRETARY FOR CONGRESSIONAL, INTERGOVERNMENTAL, AND INTERNATIONAL AFFAIRS (CI) William J. Taylor, III, Assistant Secretary CI-1, Room 7B-138, Forrestal (202) $586-5450$}

Responsible for developing, managing, and ensuring coordination of all Departmental relations with the Congress, State, territorial, local and Native American government officials, other Federal agencies, and the international community. The Assistant Secretary represents the Secretary and serves as the Department's principal point of contact with the Congress, State, local, Native American and foreign government officials, and other external organizations and groups. These activities are conducted in consultation with the White House offices on legislative and intergovernmental affairs and the Department of State on international issues.

\section{Office of Resource Management \\ T. J. Hopkins, Director \\ CI-10, Room 8G-082, Forrestal \\ (202) 586-1351}

This Office is responsible for the support activities associated with congressional, intergovernmental, and international affairs' day-to-day activities. Staff provide policy advice on administration, management, and human resources. The Office provides resource management support to the Assistant Secretary and other staff and serves as a key advisor to assist in the development of comprehensive short- and longrange organizational and resource plans; develops and implements budget formulation, presentation, and execution; and develops, coordinates, and implements Communications Plans to announce major program and policy initiatives. The Office is responsible for the coordination and scheduling of non-appropriations congressional hearings, including 
managing the departmental concurrence process for testimony, responding to questions, and editing transcripts following hearings. Provides advance notification of contract and grant awards to members of Congress. Gathers background information on congressional activities, votes and priorities, and/or interests of members of Congress and provides research and analysis of energy legislation and Congressional actions affecting energy-related issues; and develops and monitors reports that track energy legislation.

\section{Office of Governmental Relations Vacant, Director CI-20, Room 8E-070, Forrestal (202) $586-5466$}

This Office serves as the central point of contact for Congressional internationals on a day-to-day basis and provides support for the activities of the Deputy Assistant Secretaries for Senate and House Liaisons in developing legislative strategies and providing expertise on congressional interests and issues regarding legislation and hearings on sensitive legislative proposals. In addition, staff works closely with Members of Congress and their staffs and senior departmental officials on legislative initiatives and providing expertise on congressional interests and issues. Staff is also responsible for analyzing and reviewing materials relating to legislation.

\section{Office of the Deputy Assistant} Secretary for House Liaison Vacant, Deputy Assistant Secretary CI-40, Room 7B-118, Forrestal (202) $586-5468$

Office of the Deputy Assistant Secretary
for Senate Liaison
Vacant, Deputy Assistant Secretary
Cl-50, Room 7B-118, Forrestal
(202) 586-5468

These Offices provide advice and expertise to the Assistant Secretary and senior Departmental officials on policy and legislative initiatives of Congress and serve as key advisors to the Assistant Secretary in the development of legislative initiatives and strategies to support the Department's energy policies and programs.

\section{OFFICE OF THE ASSISTANT SECRETARY FOR DEFENSE PROGRAMS (DP) \\ Victor H. Reis, Assistant Secretary \\ DP-1, Room 4A-014, Forrestal \\ (202) 586-2177 \\ Office of the Executive Director for Policy, Planning, and National}

\author{
Environmental Policy Act (NEPA) \\ Coordination \\ Gregory P. Rudy, Executive Director \\ DP-3, Room 4A-019, Forrestal \\ (202) 586-2177
}

Identifies and assesses operational issues and resolves problems concerning program execution which cut across organizational lines and authorities. Coordinates the development of DP policy and the development of Strategic and Multi-Year Program Plans, manages internal DP activities in the Office of Congressional and Public Affairs, plans and coordinates DP NEPA compliance and policy activities, and oversees the operation of the executive correspondence system.

\section{Office of the Deputy Science and Technology Advisor \\ Warren P. Chernock, Deputy Director DP-4, Room 4A-045, Forrestal \\ (202) $586-7590$}

Provides input to the Science and Technology Advisor on issues that cut across major programmatic lines within DOE. Is responsible for cross-cutting assessments of weapons-related R\&D programs. Reviews and approves work for non-DOE sponsors, manages DP programs in technology transfer and education, and serves as the principal Defense Programs liaison to outside scientific organizations.

21

Office of the Principal Deputy
Assistant Secretary for Facilities
Victor Stello, Jr., Principal Deputy Assistant
Secretary for Facilities
DP-6, Room 4A-043, Forrestal
(202) 586-7972

Provides lead line management for the operation and maintenance of Defense Programs nuclear weapons production, nuclear materials production, laboratory facilities, the Savannah River Restart Special Projects Office, the Rocky Flats Program Office, and the Pantex Program Office.

\section{Rocky Flats Program \\ Office \\ Xavier Ascanio, Acting Director \\ DP-6.1, Room A-225, Germantown (301) 903-5697}

Provides coordination, technical and programmatic review, and staff support to the Principal Deputy Assistant Secretary for Facilities in directing Defense Programs activities at the Rocky Flats Plant. 


\section{Pantex Program Office \\ Daniel R. Rhoades, Director \\ DP-6.2, Room D-403, Germantown \\ (301) 903-9408}

Provides coordination, technical and programmatic review, and staff support to the Principal Deputy Assistant Secretary for Facilities in directing Defense Programs activities at the Pantex Plant.

\section{Office of Self-Assessment Francis C. Gilbert, Acting Director DP-9, Room B-230, Germantown (301) $903-5012$}

Develops and implements a comprehensive program of self-assessment for internal oversight, including policies and practices, and backfit for all Defense Programs (DP) environment, safety and health (ES\&H), and security and safeguards (S\&S) activities. Diagnoses, oversees, monitors, and reports performance of ES\&H and S\&S independent of DP organizations, with line management responsibility for these activities.

\section{Office of the Deputy Assistant Secretary for Military Applications Charles J. Beers, Jr., Deputy Assistant Secretary DP-20, Room 4C-024, Forrestal (202) $586-4879$}

Provides oversight and direction of the programs for research, development, testing, production, dismantlement, and reliability assurance of nuclear weapons; directs the program for the prevention of accidental or unauthorized nuclear detonations; maintains liaison between DOE and the Department of Defense on nuclear weapons matters; and administers activities under international agreements for cooperation involving nuclear weapons.

\section{Office of Transportation Safeguards and Emergency Management John E. Rudolph, Director DP-23, Room B-318, Germantown} (301) 903-3618

Provides Headquarters line management oversight of transportation safeguards within the weapons complex; development, maintenance, and utilization of emergency response capabilities within the complex; and access to nuclear weapons information and facilities by domestic and foreign entities.

\section{Office of Research and Advanced Technology \\ Marshall M. Sluyter, Acting Director DP-24, Room B-312, Germantown (301) $903-5491$}

Manages research activities associated with the weapons technology base, including advanced technologies, Nuclear Directed Energy Weapons (NDEW) concepts, and research and technology development such as weapons design and safety research. Provides technology-based line management.

\section{Office of Development, Testing, and Acquisition Vacant, Director DP-25, Room A-483, Germantown (301) 903-3441}

Manages all weapons testing activities, to including underground and aboveground programs.

\section{9}

Office of Weapons and Materials
Planning
Charles G. Halsted, Jr., Director
DP-27, Room A-301, Germantown
(301) 903-2402

Develops, manages, and coordinates the institutional policy (excluding weapons surety) and planning for the nuclear weapons and materials programs to assure that national defense requirements are met.

\section{Office of Inertial Confinement Fusion Marshall M. Sluyter, Director DP-28, Room B-312, Germantown (301) $903-5491$}

Plans, develops, and directs the programs for research, development, demonstration, and utilization of laser and particle beam initiated inertial fusion research related to national security.

\section{Office of the Deputy Assistant Secretary for Weapons Complex Reconfiguration Howard R. Canter, Deputy Assistant Secretary DP-40, Room 4B-014, Forrestal (202) $586-2700$}

Provides Headquarters direction and oversight for all activities leading to a Secretarial decision concerning Complex-21, program execution, and eventual field operation of Complex-21. 
Office of the Deputy Assistant

Secretary for Resource Management

David B. Leclaire, Deputy Assistant

Secretary

DP-50, Room 4A-045, Forrestal

(202) 586-2295

Responsible for the overall managerial analysis and support of Defense Programs, resource and financial management, personnel, administration, training, and support services activities.

\section{Office of the Deputy Assistant \\ Secretary for Facilities \\ Donald F. Knuth, Deputy Assistant \\ Secretary \\ DP-60, Room 4A-043, Forrestal \\ (202) $586-2185$}

Provides oversight and direction of the programs for safe production of nuclear materials. Provides, directs, and maintains the technical leadership, capabilities, and oversight to assure the operation of Defense Programs facilities in a safe and environmentally acceptable manner.

\section{Office of Engineering and Operations Support \\ Gerald E. Gears, Acting Director \\ DP-62, Room A-106, Germantown \\ (301) 903-9412}

Develops and maintains a cadre of technical experts for technical review and assessment of all Defense Programs facilities, including their design, construction, maintenance, and operations.

\section{Office of Processing and Reactor Facilities John A. Ford, Director DP-63, Room A-322, Germantown (301) 903-3782}

Provides nuclear materials to meet defense and other requirements by managing the Department's nuclear materials production and processing facilities and assuring their operation and maintenance in a safe, environmentally-sound, and secure m-iner to achieve production requirements established in the Nuclear Weapons Stockpile Memorandum.

\section{Office of Production Facilities Richard D. Hahn, Director}

DP-64, Room C-425, Germantown (301) 903-3757

Manages the Department's nuclear weapons production sites at the Y-12 Plant, Pinellas Plant, Kansas City Plant, and the Mound Plant, assuring their operation and maintenance in a safe, environmentally sound, and secure manner to achieve production requirements established in the Nuclear Weapons Stockpile Memorandum.

\section{Office of Research, Development and Testing Facilities \\ Richard C. Crowe, Acting Director DP-65, Room D-401, Germantown (301) 903-6214}

Manages the Department's Defense Programs research, development, and testing facilities (Lawrence Livermore National Laboratory, Los Alamos National Laboratory, Sandia National Laboratory and the Nevada Test Site), assuring their operation and maintenance in a safe, environmentally sound, and secure manner, and provides aviation safety oversight for all DP aviation activities.

\section{Office of Construction and Capital Projects Edward G. Lazur, Acting Director DP-66, Room B-130A, Century Twenty-One Building, Germantown (301) 903-3557}

Responsible for the planning, budgeting, and programmatic direction of construction projects for Defense Programs, including Major System Acquisitions, Major Projects, Other Line Items, Defense Programs project management policy and procedures; provides oversight of execution of projects in the fields; serves as DP-60 coordinator for nonnuclear consideration/reconfiguration activities; and provides liaison between the Defense Programs Office of the Deputy Assistant Secretary for Weapons Complex Reconfiguration and DP-60.

\section{Office of Inspections \\ Richard C. Crowe, Director DP-67, Room B-114, Germantown (301) 903-6214}

Conducts a formal audit and inspection program to provide independent and objective assessment of Defense Programs complex facilities. 


\section{0 \\ Office of Field Security Oversight \\ Willie F. Hensley, Jr., Director \\ DP-68, Room A-304, Germantown \\ (301) 903-5277}

Responsible for focal point direction, oversight, and support of the operational safeguards and security aspects of Defense Programs field offices and facilities.

\section{Office of Economic Impact and Diversity (ED)}

\section{Office of Minority Economic Impact Gloria B. Smith, Acting Director ED-2, Room 5B-110, Forrestal (202) $586-8383$}

Develops comparative socioeconomic analyses of minority energy consumption and use patterns; determines the effects of energy prices; and implements focused educational and increased technical, business, and financial assistance programs which will enhance the social and economic conditions of minorities. Programs focus on developing and implementing fluid methods to determine both the income distribution and employment effects associated with related energy policies and programs among disadvantaged population segments. The Office also develops, enhances, and establishes programs to increase minority participation in both the Department's and the energy industry's research and demonstration, grant, contract, and other program opportunities; increases their levels of involvement in the development and commercialization of energy technology alternatives; implements effective strategies to enhance the technica! and scientific skills of minorities and the quality of the minority educational infrastructure; improves the business skills and levels of participation of minorities in the high-technology energy industry segments; and develops and disseminates technical information to assist focused developmental strategies in minority and low-income communities.

\section{Office of Small and Disadvantaged Business Utilization Leonel V. Miranda, Director ED-3, Room 905, H Street (202) 254-5583}

Responsible for policy, plans, implementation, and oversight of functions relating to preference programs for small businesses; labor surplus area concerns; women-owned businesses; and minority-owned businesses, educational institutions, and organizations. The Office provides functional direction and oversight to Headquarters and field personnel in regard to execution of these programs.

OFFICE OF THE ASSISTANT
SECRETARY FOR ENERGY
EFFICIENCY AND RENEWABLE
ENERGY (EE)
Christine A. Ervin, Assistant
Secretary
EE-1, Room 6C-016, Forrestal
(202) 586-9220

Formulates and directs programs designed to develop and promote the adoption of cost-effective renewable energy and energy efficiency technologies in conjunction with the States and with partners in the transportation, building, industrial, and utility sectors. Supports research, development, and technology transfer activities. Administers statutorily mandated assistance programs.

\section{Office of the Deputy Assistant \\ Secretary for Utility Technologies \\ Robert L. San Martin, Deputy Assistant \\ Secretary \\ EE-10, Room 6C-036, Forrestal \\ (202) 586-9275}

Develops the utility technology policies and priorities by evaluating national and Departmental economic, environmental, and energy policies and statutes, current and prospective domestic and international energy demands and utilization, and by Federal funding availability. The Office activities include the technology of renewable and solar energy conversion, energy management, and advanced utility concepts. The Office is also responsible for the development, execution, and evaluation of programs and activities to affect timely transfer of technology from Federal laboratories to energy production concerns. The Office facilitates informed decisionmaking within the energy utilization community.

\section{Office of Renewable Energy Conversion Roland R. Kessler, Director EE-12, Room 5H-095, Forrestal (202) $586-8084$}

Provides overall direction, interprets policy objectives, and establishes management procedures for a balanced program that will foster the establishment of renewable or alternate energy supply options, such as wind, ocean, hydroelectric, and geothermal, for use by utilities and allied industries and institutions.

\section{Wind, Hydro, and Ocean Division \\ Ronald R. Loose, Director \\ EE-121, Room 5H-047, Forrestal \\ (202) $586-5348$}


Responsible for managing the development, implementation, and evaluation of a national program of technology planning of research and development, test and evaluation of hydroelectric, wind, and ocean energy. The Division also formulates and integrates the scientific, engineering, and technical requirements necessary to structure a feasible and effective research and development program.

\section{Geothermal Division John E. Mock, Director EE-122, Room 5H-065, Forrestal (202) $586-5340$}

Responsible for managing the development, implementation, and evaluation of a national program of geothermal technology planning, research and development, and testing and evaluation, including scientific, engineering, and technical requirements.

\section{Office of Solar Energy Conversion \\ Robert $H$. Annan, Director \\ EE-13, Room 5H-072, Forrestal \\ (202) $586-1720$}

Directs and interprets policy objectives, and establishes management procedures for a balanced program of technology planning, research, and development that will foster the establishment of solar energy supply options for use by utilities and allied industries and institutions.

\section{Photovoltaics Division \\ James E. Rannels, Director \\ EE-131, Room 5H-088, Forrestal (202) $586-1721$}

Responsible for managing the development, implementation, and evaluation of a national photovoltaic energy program of technology planning, research, testing, and evaluation. The Division also formulates and integrates the scientific, engineering, and technical requirements to structure a feasible and effective photovoltaic research and development program.

\section{Solar Thermal and Biomass Power Division Gary D. Burch, Director EE-132, Room 5H-088, Forrestal (202) $586-8121$}

Responsible for managing the development, implementation, and evaluation of a national program of solar energy; thermal and biomass energy; and power technology planning, research, testing, and evalua- tion. The Division also formulates and integrates the scientific, engineering, and technical requirements to structure a feasible and effective research and development program.

\section{Office of Energy Management Marvin E. Gunn, Jr., Director EE-14, Room 6H-034, Forrestal (202) $586-2826$}

Directs and interprets policy objectives for program planning, research and development, and management procedures fostering the establishment of advanced electric system options, providing improved analytical and planning methods, and additional knowledge of grid system impacts for use by utilities, allied industries, and institutions. The Office is also responsible for the development of advanced technology, design, and analytical techniques for use in district heating, shared energy cooperatives, and other community energy systems. The Office plays a key role in advanced energy concepts involving improved energy conversion or more efficient energy utilization for use by utilities and allied industries and instilu:tions.

\section{Utility Systems Division Robert H. Brewer, Director EE-141, Room 6H-034, Forrestal (202) $586-2828$}

Plans and manages a balanced program of research, development, and evaluation that will result in new technologies to improve the generation and transmission of electricity, the reliability of electric networks, and the impacts resulting from the generating and transmission activities. The Division also researches new methods and techniques for addressing energy demand and supply options that will enable more efficient delivery and use of energy in community shared systems.

\section{Advanced Utility Concepts Division Russell Eaton, III, Director EE-142, Room 6H-034, Forrestal (202) 586-0205}

Plans and manages a balanced program for technology research and development to provide the technology base enhancing the use of advanced utility concepts, such as superconductivity, conversion, or transmission options, electrochemistry, battery and storage in electrical utility load leveling, and industrial, commercial, and residential applications. 


\section{Office of the Deputy Assistant Secretary for Industrial Technologies Alan J. Streb, Deputy Assistant Secretary EE-20, Room 6B-052, Forrestal \\ (202) 586-9232}

Develops and evaluates a national program of technology planning research and development, designed to increase energy end-use efficiency to promote renewable energy use in industrial applications and enhance industrial productivity. The program would also reduce industrial and municipal waste stream volume and associated environmental impact and hazard through selective support of research and development leading to minimization, treatment, detoxification, and reuse of waste stream materials. The Office also identifies, supports, and transfers the results of research in combustion, heat transfer, thermodynamics, mechanics, materials chemistry processing, electrochemistry, and biocatalysis.

\section{Office of Waste Reduction Technologies \\ Donald K. Walter, Director \\ EE-22, Room 5G-067, Forrestal \\ (202) $586-2090$}

Develops and maintains a balanced program of research and development on generic technologies enhancing the reduction or utilization of wastes, the application of solar to industrial processes and the delivery of industrial energy with wide application throughout industry and agriculture. The program includes activities in waste heat recovery, improved thermal energy management, cogeneration systems, waste products utilization and reduction, including municipal solid wastes and waste stream detoxification. The Office also performs analyses to identify future technological opportunities and impediments to deployment of proven energy efficient technologies.

\section{Industrial Energy Efficiency Division \\ Kurt D. Sisson, Acting Director \\ EE-221, Room 5F-035, Forrestal \\ (202) 586-6750}

Manages the development, implementation, and evaluation of a national industrial energy efficiency program of technology planning, research, and development for waste heat recovery, thermal energy management, cogeneration, and combustion equipment.

\section{Waste Material Management Division \\ Kurt D. Sisson, Director \\ EE-222, Room 5F-035, Forrestal \\ (202) $586-6750$}

Develops and maintains a balanced program of waste material management research and development to establish a technology base from which industry can develop feasible concepts for the reduction or utilization of industrial and municipal wastes and the use of solar for hazardous waste detoxification or industrial energy.

\section{Implementation and Deployment Division Jerry D. Duane, Director EE-223, Room 6H-034, Forrestal (202) $586-2366$}

Develops and maintains a balanced program to enhance energy efficiency in industry through the transfer of advanced industrial technologies from completed and ongoing research and development to the private sector. Stimulates interest in energy management education. Provides direct technical assistance and information to the industrial sector through university energy analysis and diagnostic centers.

\section{Office of Industrial Process \\ Peter H. Salmon-Cox, Director EE-23, Room 5F-059, Forrestal (202) $586-2380$}

Develops and maintains a balanced program of costshared research and transferring of new technologies with applications to the most energy intensive processes. Activities include the development of revolutionary high and low temperature technologies and the support of underlying scientific work in energy conversion.

\section{Advanced Industrial Concepts Division Peter H. Salmon-Cox, Acting Director EE-232, Room 5F-059, Forrestal (202) $586-2380$}

Develops and maintains a balanced, high-risk, longterm, interdisciplinary research program to improve energy efficiency and enhance fuel flexibility. The Division also identifies, supports, and transfers the results of research and provides evidence of technical feasibility of advanced industrial concepts in the areas of combustion, such as heat transfer, energy conversion, and bioprocessing. 


\section{Separations Division Daniel E. Wiley, Director EE-233, Room 5F-059, Forrestal (202) $586-9488$}

Supports activities which reduce technical and/or economic risks preventing industry from investing in more energy-efficient processes, technologies, and practices. Cost-shares research and development projects which industry would not undertake on its own for a variety of reasons. Research and development projects particularly important in achievement of objectives include advanced energy-efficient separation technologies, such as membrane systems and solid and liquids concentration processes; improvement of sensors, measurement and control systems; and development of improved processes for low temperature industries, such as paper, chemicals, petroleum refining, food processing, and textiles.

\section{Material Processing Division Matthew J. McMonigle, Director EE-234, Room 5F-059, Forrestal (202) $586-5377$}

Conducts a balanced research and development program for energy intensive industrial processes, such as melting and casting and extracting material from rock and ore. Key industries include steel, aluminum, copper, magnesium, foundry, glass, and cement. The cross-cutting activity of refractory development, as well as research and development on non-metallic materials and process electrolysis, is also part of the R\&D program.

\section{Office of the Deputy Assistant Secretary for Transportation Technologies Thomas J. Gross, Acting Deputy Assistant Secretary EE-30, Room 6B-094, Forrestal (202) $586-8027$}

Formulates, executes, and evaluates a national program of research and development for promising technologies that will improve fuel use efficiency and will result in displacement of petroleum by alternative fuels in the transportation sector. The Office evaluates economic, environmental, and energy policies and statutes; current and prospective domestic and international transportation energy demands and utilization; and appropriate application of Federal funds. The Office is responsible for defining and implementing programs that realize the economic and technical potential of advanced transportation technologies; reflect industrial, economic, and financial concerns; and account for the capabilities, decisions, and interests of energy users. The Office assures that transportation technologies are properly reflected in the formulation of national energy and economic policies. The Office coordinates national and international programs having a bearing upon the competitive position of U.S. industry.

\section{Office of Propulsion Systems John J. Brogan, Director EE-32, Room 5G-030 Forrestal (202) 586-1477}

Interprets policy objectives and manages a balanced program of technology planning, research, development, and demonstration of advanced transportation propulsion systems, including electric, hybrid, and fuel cell vehicles. The objectives of this program are to apply the state-of-the-art in transportation technology, in partnership with industry, to significantly reduce the use of petroleum while improving air quality, increasing transportation efficiency, and improving national productivity.

\section{Electric/Hybrid Propulsion Division Kenneth F. Barber, Director EE-321, Room 5G-030, Forrestal (202) $586-2198$}

Manages the development, implementation, and evaluation of a national electric and hybrid propulsion research and development program designed to reduce consumption of petroleum and to provide fuel flexibility for highway vehicles. The Division is alsc responsible for analyzing performance data on fleet operations, transportation energy use, petroleum savings, and other benefits which may be derived from the use of electric vehicles.

\section{Advanced Propulsion Division Thomas M. Sebestyen, Director EE-322, Room 5G-046, Forrestal (202) $586-8012$}

Manages the development of a national advanced transportation, propulsion, and demonstration program of advanced engine and velucular systems development. Manages projects advancing the state of technology which can be applied to future vehicle propulsion systems. Emphasizes technology research for advanced propulsion systems, such as ceramic gas turbines, adiabatic diesels, and low heat rejection designs, as well as research on fuels which could result in lower emissions while simultaneously improving fuel economy performance. 
Office of Alternative Fuels

Jerry R. Allsup, Director

EE-33, Room 5G-086, Forrestal

(202) $586-9118$

Interprets policy objectives. Directs and manages a balanced program of technology planning, research, and demonstration of promising alternative fuel vehicles and production technologies for alternative fuels. The Office examines both fuels and engines, and performs the necessary research, testing, information gathering, and data analyses to determine the least costly and most environmentally beneficial combinations. The most effective options for providing personal and freight mobility are identified and promoted.

\section{Biofuels Systems Division Raymond Costello, Acting Director EE-331, Room 5G-086, Forrestal (202) 586-8072}

Plans and manages a balanced program for technology research, development, testing, and evaluation which will foster the establishment of biofuels supply options. The Division is also responsible for developing technologies to produce competitive alternative liquid and gaseous fuels, such as alcohols, biogasoline, and methane. The Division develops the necessary technologies to grow, harvest, and transport renewable feedstocks, as well as the technologies to convert these feedstocks to fuels.

\section{Fuels Utilization Data and Analysis Division John A. Russell, Director EE-332, Room 5G-086, Forrestal (202) 586-8053}

Develops and manages a balanced program to foster the use of fuels in the transportation sector. This program will provide industry and the technical community with reliable information and data on engine design parameters and trade-offs for potential fuel-engine options, and reliable and correlative data on performance and emissions. The Division also develops a technology base for the use of alternative fuels in both current and advanced engines. The Division conducts evaluation and demonstration activities according to the Alternative Motor Fuel Act of 1988, manages the program to increase alternative fuels in the Federal Fleet, and is responsible for the National Alternative Fuels Data Center.

\section{Office of Advanced Transportation Materials James J. Eberhardt, Director BE-34, Room 5G-064, Forrestal (202) 586-9837}

Develops and manages a balanced research and development program for advanced materials and tribology technologies. This Office establishes the technology base necessary for: industrial production and development of reliable and cost-effective ceramic engine components; lightweight materials; and materials for use in alternative fuel vehicles. Activities include materials and processing technology development, design methodology, materials data base life prediction, tribology development, and operation of the High Temperature Materials Laboratory at Oak Ridge, Tennessee.

\section{1}

Office of the Deputy Assistant Secretary for Building Technologies John P. Millhone, Deputy Assistant Secretary EE-40, Room 6A-081, Forrestal (202) $586-1510$

Formulates, executes, and evaluates a national program of technology planning, research, and development to support the private sector in increasing the energy efficiency of the Nation's residential, commercial, and industrial buildings and enhancing the utilization of systems for building energy supply options. The Office performs energy efficiency planning and management programs for Federal buildings. The Office also provides associated information and financial incentives and performs regulatory functions as determined by the Federal Government.

\section{Office of Building Energy Research Theodore Kapus, Director EE-42, Room 5H-048, Forrestal (202) $586-9123$}

Formulates and evaluates a national program of technology planning, research, and development to provide support to the private sector in increasing the energy efficiency of the Nation's residential, commercial, and industrial buildings and building equipment and enhancing the utilization of active and passive systems for solar energy technology. The Office also develops a comprehensive program to transfer technological advancement information to the private sector, facilitating decisions by energy users. 


\section{Building Systems and Materials Division \\ Richard H. Karney, Director EE-421, Room 5E-098, Forrestal (202) 586-9445}

Develops and manages a balanced program of technology planning, research, and development to provide a technical basis for substantially increasing the energy efficiency of new and existing buildings. Division programs enhance private sector activities in the area of building energy sciences, including solar building technologies. These activities provide the scientific and technical basis upon which to advance knowledge of energy phenomena in buildings. The Division also develops a comprehensive program to transfer technological advancement information to the private sector, facilitating informed decisions by technology users.

\section{Building Equipment Division John D. Ryan, Director EE-422, Room 5H-048, Forrestal (202) $586-9130$}

Formulates, executes, and evaluates a national program of technology planning, research, and development to supply the private sector with the technological basis for developing and testing high efficiency and solar equipment used in the operation of residential and commercial buildings. The Division defines program activities that reflect energy efficient potential and recognizes the nature of international competitiveness and the interests of the users. The Division also develops a comprehensive program to transfer equipment technology advancements and information to the private sector, facilitating informed decisions by energy users.

\section{Office of Codes and Standards Michael J. McCabe, Director EE-43, Room 5E-066, Forrestal (202) $586-9127$}

Formulates programs to implement the legislative requirements for building energy performance standards and appliance efficiency standards. Implementation of the requirements of the Appliance Standards legislation requires the development, revision, and update of the DOE test procedures for consumer products. These procedures are used by manufacturers of major residential appliances to compute energy information needed for appliance energy guide labels. Comprehensive analysis is also per- formed for the purpose of setting maximum energy efficiency standards that are technologically feasible, economically justified, and conserve significant amounts of energy.

\section{Appliance Division \\ Carl E. Adams, Director \\ EE-431, Room 5E-066, Forrestal \\ (202) 586-9142}

Carries out the requirements of Public Law 94-163, as amended. Division program activities include the development of appliance test procedures, promulgation and implementation of appliance energy conservation standards, and technical support and consumer education activities for the Federal Trade Commission appliance labeling program.

\section{Buildings Division Jean J. Boulin, Director EE-432, Room 5E-066, Forrestal (202) 586-0517}

Carries out the requirements of Public Law 94-385, as amended by Public Law 97-35. Activities required include development of energy conservation standards for new buildings, development of demonstration projects, administration of rulemaking for building standards, and technical support of the U.S. Housing and Urban Development semi-annual reports to Congress on State/local implementation standards for new buildings.

\section{Office of Federal Energy Management Programs \\ Mark B. Ginsberg, Director \\ EE-44, Room 5E-080, Forrestal \\ (202) $586-5772$}

Plans and manages energy conservation for the Federal Government. Specific objectives include reducing total energy consumption by the Federal Government; increasing efficiencies and reducing costs; altering the fuel mix within the Federal consumption total; enhancing the use of renewable energy fuels; and reducing dependence on imported fuels. The program attempts to set an example for the Nation by transferring the Federal energy experience to State and local governments and, ultimately, the private sector. The Office also develops and implements a comprehensive schedule for achieving legislative milestones and plans for effecting the required transfer of information. 
Office of the Deputy Assistant Secretary for Technical and Financial Assistance

Frank M. Stewart, Jr., Deputy Assistant

Secretary

EE-50, Room 6A-049, Forrestal

(202) $586-9240$

A primary mission of the Office of Technical and Financial Assistance (OTFA) is to assist the EE end-use sector offices in the market deployment, domestically and internationally, of energy efficiency and renewable energy technologies and practices. The Office manages and--in its relations with State and local governments--works through the $10 \mathrm{DOE}$ regional support offices. The Office also plans, develops, and administers legislatively established nationwide programs of technical and financial assistance directed toward increased energy efficiency and renewable energy applications at the State and local levels.

The DOE regional support offices are listed below.

\section{Atlanta Support Office}

Buddy L. Jackson, Director

U.S. Department of Energy

730 Peachtree Street, N.E. \#876

Atlanta, GA 30308

(404) 347-2837

Fax: (404) 347-3098

Boston Support Office

Hugh Saussy, Director

U.S. Department of Energy

1 Congress Street, Suite 1101

Boston, MA 02114

(617) $565-9700$

Fax: (617) 565-9723

Chicago Support Office

William S. Becker, Director

U.S. Department of Energy

9800 South Cass Avenue

Argonne, IL 60439

(708) 252-2220

Fax: (708) 252-2071

Dallas Support Office

Curtis E. Carslon, Jr., Director

U.S. Department of Energy

1420 W. Mockingbird Lane, Suite 400

Dallas, TX 75247

(214) 767-7248

Fax: (214) 767-7231
Denver Support Office

Al Hymer, Director

U.S. Department of Energy

2801 Youngfield Street, Suite 380

Golden, CO 80401-2266

(303) 231-5750 Ext. 133

Fax: (303) 231-5757

Kansas City Support Office

Ronald Brown, Director

U.S. Department of Energy

911 Walnut Street, 14th Floor

Kansas City, MO 64106

(816) 426-5533

Fax: (816) 426-6860

New York Support Office

Charles Baxter, Director

U.S. Department of Energy

26 Federal Plaza, Suite 3437

New York, NY 10278

(212) 264-6335

Fax: (212) 264-9805

Fax: (212) 264-2272

Phildelphia Support Office

Christopher McGowan, Director

U.S. Department of Energy

1880 JFK Boulevard, Suite 501

Philadelphia, PA 19102-7483

(215) 656-6950

Fax: (215) 656-6981

San Francisco Support Office

Martha Dixon, Director

U.S. Department of Energy

1333 Broadway

Oakland, CA 94612

(510) 637-1941

Fax: (510) 637-2017

Seattle Support Office

Kathy M. Vega, Director

U.S. Department of Energy

800 Fifth Avenue, Suite 3950

Seatle, WA 98104

(206) 553-1132

Fax: (206) 553-7231

80 Office of National Programs

Harry L. Lane, Director

EE-52, Room 5E-052, Forrestal

(202) 586-9104

Manages, through the regional support offices, statutory technical and financial assistance programs to support the development and implementation of com- 
prehensive energy programs by State and local governments; these activities include, also, targeted information services. Through ccoperative agreements or similar mechanisms, works in partnership with States, local governments, the private sector, and other Federal agencies to carry out targeted technology demonstration and deployment projects. Provides technical and business planning assistance to entrepreneurs and innovators working in energy-related activities. Addresses public information, education, and other obstacles to the adoption of specific energy efficiency and renewable energy technologies. Administers the Regional Biomass Program. The Office also manages the Petroleum Violation Escrow Oversight Program.

\section{Inventions and Innovation Division \\ Terry M. Levinson, Director \\ EE-521, Room 5E-052, Forrestal \\ (202) 586-1479}

Carries out programs of support for development of technologies outside the Federal research and development system. Two principal programs, the EnergyRelated Inventions Program (ERIP) and the Innovative Concepts Program (ICP), help non-Federal entities to identify, evaluate, and provide financial and technical support for inventions and innovations that may have a significant impact on energy production or utilization. The ERIP staff provides assistance, such as technology commercialization education, technical support, grants and introductions to other sources of assistance, to advance the prospects of commercialization of the recommended technologies. ERIP invites independent and small company inventors to submit invention development proposals under a permanent, open solicitation. The Division then performs a technical evaluation of the invention disclosure submission, and, on the basis of technical merit and energy impact potential, recommiends the most promising inventions to DOE for consideration of support. ERIP, established by the Federal Non-Nuclear Research and Development Act of 1974 (P.L. 93-577), is a joint effort of the National Institute of Standards and Technology (NIST) and DOE. The other program, ICP, identifies innovative concepts for saving energy and improving industrial productivity; provides small contracts to support concept development; and conducts activities to locate other sources of assistance to develop the technologies beyond the concept stage.

\section{State Energy Programs Division \\ James P. Demetrops, Director EE-522, Room 5E-052, Forrestal (202) 586-9187}

Administers the State Energy Conservation Program (SECP) authorized by the Energy Policy and Conser- vation Act (EPCA) and the Energy Extension Service (EES) established by the National Energy Extension Service Act (NEESA). The Division works through regional, State, and local government organizations to encourage energy conservation and the adoption of renewable resources among energy users. The Division also promotes the best uses of energy technologies and techniques and the national dissemination of information on energy technologies and techniques. The EES was recently repealed by P.L. 102-486, the Energy Policy Act of 1992. DOE is encouraging States to incorporate EES functions (providing small-scale energy users with personalized information and technical assistance) into a more broadly defined SECP.

\section{Office of Grants Management Howard S. Coleman, Director EE-53, Room 5G-045, Forrestal (202) 586-1539}

Manages-through the DOE regional support offices-the Institutional Conservation and Weatherizatir Assistance Programs. Provides information, tech ra. consultation, and financial assistance for improving energy efficiency processes, systems, and practices in buildings used or occupied by specific groups, such as schools, hospitals, residences of the elderly, the low income, and other sectors of high energy dependence. The Office also manages the Geothermal Loan Guarantee Program.

\section{Institutional Conservation Program Division \\ Robert K. Volk, Jr., Direc'cor EE-531, Room 5G-063, Forrestal (202) $586-8034$}

Develops and administers DOE's conservation programs to increase the level of energy efficiency and the use of alternative energy sources in public and private nonprofit school and hospital buildings. The Division promotes energy conservation in all energy systems of these institutions and tries to reduce the expenditure of funds for nonrenewable energy resources. The Division administers Title III of the National Energy Conservation Policy Act (NECPA); encourages energy efficiency in the buildings of eligible institutions; gathers and maintains data on institutional buildings supported through these assistance activities; and determines the potential for renewable applications in these buildings. The Division also reviews, aggregates, and analyzes the States' data regarding these institutions and reports to the Department, Congress, and the public progress made by these institutions in improving energy efficiency. 
Weatherization Assistance Program

Division

Jeanne Van Vlandren, Director

EE-532, Room 5G-023, Forrestal

(202) 586-2204

Develops and implements a national program to weatherize the homes of low-income persons, the elderly, and the handicapped. The program promotes the installation of energy efficient devices and provides training and technical assistance to State and local governments, Indian tribes, and program beneficiaries. The Division implements the Weatherization Assistance Program authorized by the Energy Conservation and Production Act (ECPA), as amended, and conducts the energy conservation programs of the Federal Government.

\section{Office of Technical Assistance \\ Ronald W. Bowes, Director \\ EE-54, Room 5E-036, Forrestal \\ (202) $586-5517$}

Develops national and international programs that provide technical assistance to a wide range of energy users and to renewable energy and energy efficiency industries. The Office coordinates the resources of public and private sector organizations to enhance the role of U.S. energy technologies in the world marketplace and provides technical assistance and information to energy users and their intermediaries, local governments, and trade and professional associations to increase the use of energy efficient and renewable energy technologies.

\section{Office of Management and Resources Mariana L. Uhrlaub, Acting Director EE-60, Room 6C-026, Forrestal (202) $586-6768$}

Serves as the management policy development, implementation, and oversight arm of the Assistant Secretary. Acts as a consultant and advisor to the Assistant Secretary and line organizations in areas such as: management policy, budget preparation and execution; program management review; facilities coordination and utilization; internal/external communications; and administrative support.

88 Management Systems Institutional
Interactions Division
Mariana L. Uhrlaub, Acting Director
EE-62, Room 6C-026, Forrestal
(202) 586-6768

Provides direct staff assistance to the immediate Office of the Assistant Secretary and the program offices under his/her supervision in the development and implementation of management programs designed to assure maximum utilization of total EE resources and coordination of institutional activities, such as internal/external liaison and information dissemination services; implementation of the Federal Managers' Financial Integrity Act; Inspector General/General Accounting Office reviews; organizational reviews; and manpower planning and utilization, skill assessment, and support service usage reviews. In addition, the Division is responsible for a full range of administrative support services for the EE program offices.

89

\section{Budget and Financial Management Division Fred Glatstein, Director EE-63, Room 6B-018, Forrestal (202) 586-9262}

Provides direct staff assistance to the immediate Office of the Assistant Secretary and the program offices in a broad range of budget and financial management areas, including budget preparation and execution, development of budget and acquisition strategies, procurement and financial assistance, and loan guarantees.

\section{Facilities and Systems Coordination Division \\ Ted L. Kurkowski, Director EE-64, Room 6B-113, Forrestal (202) 586-9273}

Assigned Departmental responsibility for the institutional development and maintenance of the National Renewable Energy Laboratory as well as other EE specific facilities at Oak Ridge National Laboratory, Sandia National Laboratory, Argonne National Laboratory, Lawrence Berkeley Laboratory, Pacific Northwest Laboratory, and other national laboratories. In addition, the Division is responsible for development, implementation, and coordination of environmental, safety and health, and quality assurance programs under the Office of the Assistant Secretary.

\section{Office of Planning and Assessment Kenneth G. Moore, Director EE-70, Room 6A-025, Forrestal (202) $586-0515$}

Directs strategic planning, program and technology multi-year planning, and program and policy evaluation for the Office of Energy Efficiency and Renewable 
Energy and serves as the lead office within EE for establishing and maintaining a coordinated and consistent national program for the data, models, and applied analysis necessary for sector program integration. The Office also provides the Assistant Secretary with independent analytic support for strategic and topical issues impacting near-term program composition, policy-related Federal or State legislation, and regulation of energy markets.

\section{2}

\author{
Office of Alcohol Fuels \\ Daniel E. Beckman, Acting Director \\ EE-80, Room 6A-045, Forrestal \\ (202) $586-2340$
}

Manages Departmental programs of Federal assistance for alcohol fuels production. Develops, executes, and administers Federal assistance programs. Monitors the market and encourages the development and utilization of alcohol fuels. Acts as primary coordinator for alcohol fuels assistance programs with the Department of Agriculture and other Federal agencies. Acts as liaison with State and local governments.

\section{OFFICE OF THE ASSISTANT SECRETARY FOR ENVIRONMENT, SAFETY AND HEALTH (EH) \\ Tara J. O'Toole, Assistant Secretary \\ EH-1, Room 7A-097, Forrestal (202) 586-6151}

Assures conformance of the Department's activities with all applicable environmental laws and regulations and protection of the health and safety of workers and the public; that national environmental protection goals are incorporated in energy programs; and that environmental and safety concerns are addressed through corrective and remedial actions. Develops policy options concerning the effects of national environmental policy on U.S. energy industries and energy supply and demand.

\section{Office of the Deputy Assistant Secretary for Security Evaluations Glenn S. Podonsky, Deputy Assistant Secretary EH-4, Room C-303, Germantown (301) 903-3777}

Responsible for independent oversight of the effectiveness of the Department's safeguards and security policies, programs, and their implementation in the field.

\section{Office of Inspections \\ Vacant, Director \\ EH-4.2, Room C-320A, Germantown \\ (301) $903-8400$}

Responsible for field inspection, evaluation, and performance testing to determine the effectiveness of safeguards and security policies and programs implemented in the field.

\section{Office of Plans, Technology and Certification James H. Ware, Director EH-4.3, Room C-320B, Germantown (301) $903-5982$}

Responsible for trend analysis and assessing the effectiveness of safeguards and security policies and programs throughout the Department of Energy.

\section{Office of Special Projects Mark A. Gilbertson, Acting Director EH-5, Room 1G-080, Forrestal (202) $586-5042$}

Conducts assessments of environment and safety and health management programs and systems; provides training to transfer assessment-related skill throughout the Department of Energy; develops policy and works to identify and resolve management issues which span the individual technical areas of environment, safety and health; manages an environment, safety and health information and analysis program; and participates in the Department of Energy planning processes to ensure that environment, safety and health concerns receive proper attention.

Office of the Deputy Assistant
Secretary for Nuclear Safety
Thomas A. Rollow, Acting Deputy Assistant
Secretary
EH-10, Room 7A-121, Forrestal
(202) 586-2407

Provides independent nuclear safety oversight of DOE facilities and programs under the purview of the Assistant Secretary for Environment, Safety and Health. In the process, the Office works with DOE line management to ensure the Secretary of Energy and, in turn, the Congress and the public, that DOE workers, the public, and the environment receive the highest level of health and safety protection reasonably achievable from DOE nuclear operations. 
Office of Nuclear Safety Performance

Assessment

Silas D. Stadler, Director

EH-11, Century XXI, Room 342

20130 Century Boulevard

Germantown, MD 20874

(301) 903-5392

Oversees performance of line program organizations in managing and assuring nuclear safety at DOE facilities. Assesses operational readiness of nuclear facilities, significant events and technical issues, and routine nuclear safety functions. The Office also reviews proposed nuclear safety rules and orders; participates in seminars and workshops involving nuclear safety; monitors facility and line management performance; and disseminates operating experience and lessons learned. The Office consists of experts in conducting assessments and in technical disciplines, such as nuclear, mechanic..!, electrical, and chemical engineering; facility operations and maintenance; radiological protection; training; and criticality safety.

\section{Office of Nuclear Safety Risk and Policy Analysis \\ Andrew R. Marchese, Director \\ EH-12, Century XXI, Room 324 \\ 20130 Century Boulevard \\ Germantown, MD 20874 \\ (301) $903-2712$}

Oversees development and implementation of nuclear safety policies, rules, orders, and guides. The Office reviews facility safety analysis reports for consistency and assurance that nuclear safety policies, rules, orders, and guides are followed; conducts probabilistic risk assessments and accident analyses in environmental documents to ensure consistent data bases and methodologies are used; studies emergency preparedness plans to ensure adequate protection of the public; and assesses analyses of vulnerability of DOE nuclear facilities to natural hazards phenomena. The Office also works with national and international standards bodies in identifying new standards for design, construction, operation, and decommissioning of reactors and other nuclear facilities. The Office is comprised of experts in risk analysis; natural hazards phenomena; emergency preparedness; and civil, chemical, electrical, mechanical, nuclear, and design engineering.

\section{Office of Nuclear Safety Enforcement \\ Richard L. Black, Director \\ EH-13, Century XXI, R.oom 302 \\ 20130 Century Boulevard \\ Germantown, MD 20874 \\ (301) 903-0102}

The Office of Nuclear Safety Enforcement implements DOE's statutory nuclear safety enforcement program and investigates potential violations of nuclear safety requirements to determine whether civil or criminal sanctions are warranted. The Office works closely with the Inspector General, as well as the General Counsel, in developing enforcement policies and procedures. The Office implements its enforcement authority by establishing effective and voluntary compliance assurance programs and processes. The Office also audits contractor and DOE employee concerns programs to assess their effectiveness. The Office contains attorneys and professional investigators knowledgeable of nuclear operations in a regulatory environment.

\section{Office of Nuclear Safety Field Programs Thomas A. Rollow, Director EH-14, 7A-121, Forrestal (202) $586-2407$}

The on-site offices in the Office of Nuclear Safety Field Programs provide independent feedback and advice to the Deputy Assistant Secretary for Nuclear Safety, with the aim of promoting self-assessment and a desirable nuclear safety culture, and assuring adequate nuclear safety margins are maintained. On-site office personnel, located at DOE Operations Offices, routinely observe nuclear safety operations, conduct systematic audits at DOE nuclear sites and facilities, and interact with senior DOE managers on nuclear safety issues.

\section{Office of Nuclear Safety Technical Support and Systems Management Russell S. Scott, Acting Director EH-15, Room 471, Quince Orchard Road Gaithersburg, MD 20878 \\ (301) 427-1682}

Provides for the administrative and management support, program control, and coordination of the resources of the Deputy Assistant Secretary for Nuclear Safety and that Office.

\section{Office of Nuclear Safety Radiological Oversight \\ Edward E. Blackwood, Director EH-16, Century XXI, Room 316 20130 Century Boulevard Germantown, MD 20874 (301) 903-0120}

The Office of Nuclear Safety Radiological Oversight works for continuous improvement in radiological protection and control (Radcon) through oversight of 
DOE's operations requiring protection. By assessing Radcon practices, analyzing deficiencies and good practices that reflect the quality of operations, and communicating results, the Office works with DOE and contractor nuclear organizations to foster improvements and instill a proper appreciation for the importance of conservative, effective Radcon policies and practices. The Office employs a balanced mix of radiological control evaluations, program oversight, and radiological improvement initiatives. The Office is made up of engineers, health physicists, and technical experts with backgrounds in facility operations and nuclear-related scientific and engineering disciplines.

\section{Office of the Deputy Assistant Secretary for Environment Raymond P. Berube, Deputy Assistant Secretary EH-20, Room 7A-075, Forrestal (202) $586-5680$}

Responsible for the management and direction of comprehensive programs that develop and implement policies, programs, standards, and procedures to attain and maintain compliance of all Department operations and facilities with all relevant environmental statutes, regulations, orders, and guidelines.

\section{Office of Environmental Compliance Kathleen I. Taimi, Director EH-22, Room 3G-092, Forrestal (202) $586-2113$}

Establishes and promotes Departmental environmental compliance policies and complexwide strategies for attaining and maintaining environmental compliance. Provides leadership and support to active and inactive DOE facilities to assist in the consistent implementation of Departmental environmental compliance and policies, and the resolution of complexwide and significant site-specific compliance issues. Represents the Department in external forums with other Federal agencies, State organizations, and citizen groups to communicate, coordinate and/or promote DOE's environmental compliance policies; and to provide environmental leadership and expertise for the resolution of priority intergovernmental Federal facility compliance issues and the implementation of Federal environmental improvement initiatives.

\section{Compliance Strategies Division Andrew C. Lawrence, Director EH-221, Room 3G-092, Forrestal (202) $586-5358$}

Develops Departmental environmental compliance policies and strategies to correct existing complexwide compliance deficiencies and to minimize or preclude future Departmental compliance problems. Provides expert advice to senior Department officers regarding DOE environmental compliance policies. Evaluates multi-program cross-cutting environmental compliance issues, identifies trends, and anticipates future issues requiring policy analysis and strategy development. Coordinates resolution of significant environmental compliance issues affecting the DOE complex.

\section{Facility Compliance Division Randall L. Kaltreider, Director EH-222, Room 3G-089, Forrestal (202) $586-4440$}

Coordinates the review and resolution of significant facility-specific environmental compliance issues and related activities. Provides policy and technical support to field and program offices to ensure that facility-specific regulatory compliance strategies are consistent with Departmental policies. Serves as DOF focal point for interaction with EPA on current significant site-specific environmental compliance issues.

\section{Office of Environmental Guidance Raymond Pelletier, Director EH-23, Room GA-098, Forrestal (202) $586-8505$}

Responsible for developing written compliance policies, standards, guidance documents, and internal DOE orders which cover the full range of environmental statutes and regulations. The Office monitors regulatory and legislative developments, keeps DOE personnel abreast of emerging and changing environmental requirements, coordinates the development of Departmental positions, and serves as the advocate for DOE's position with respect to other agencies' rulemaking efforts.

\section{RCRA/CERCLA Division Thomas T. Traceski, Director EH-231, Room GA-076, Forrestal (202) $586-2481$}

Develops written DOE-wide orders, policies, standards, and guides to assure understanding of and compliance with the requirements of the Resource Conservation and Recovery Act (RCRA) and the Comprehensive Environmental Response, Compensation and Liability Act (CERCLA) by DOE facilities and operations. Coordinates and develops the Departmental position on emergency RCRA/CERCLA requirements. 


\section{Air, Water and Radiation Division Andrew Wallo, III, Director EH-232, Room GA-098, Forrestal (202) 586-4996}

Develops written DOE-wide orders, policies, standards, and guides to assure understanding of and compliance with the appropriate environmental laws, regulations, and standards to protect the public. Coordinates and develops the Departmental position on emerging air, water, and radiation protection requirements, including radioactive waste and risk management. Provides training on air, water, and radiation laws, regulations, policies, and standards to DOE and contractor personnel.

\section{Office of Environmental Audit Michael A. Kilpatrick, Director EH-24, Room 3E-094, Forrestal (202) 586-4419}

Ensures that the Department's operating and nonoperating facilities are in compliance with all applicable environmental requirements. The mission is accomplished by conducting integrated assessments to establish a baseline of environmental compliance status at the facility level; assessing the effectiveness of environmental management systems at the facility or program level; and conducting routine re-audits of facilities or programs to monitor improvement. As a result of these assessment activities, high priority environmental issues that cross site and program lines are identified and further evaluated. These activities also identify opportunities to assist the line programs in improving their environmental auditing and selfassessment skills. The Office also conducts an Environmental Auditing Training course.

\section{Office of National Environmental Policy Act (NEPA) Oversight Carol M. Borgstrom, Director EH-25, Room 3E-080, Forrestal (202) $586-4600$}

Ensures that the Department's proposed actions comply with the NEPA and other environmental review requirements (e.g., National Historic Preservation Act, Endangered Species Act, Fish and Wildlife Coordination Act, and others) that are necessary prior to project implementation. The Office is the focal point for NEPA expertise and NEPA-related activities in all program areas covering virtually every facet of the Department's operations.

\section{Waste Activities Division Stanley Lichtman, Director EH-251, Room 3E-080, Forrestal (202) $586-4610$}

Ensures that the Department's proposed projects and programs involving wastes (radioactive, hazardous, nonhazardous) in both environmental restoration (e.g., CERCLA compliance projects and Uranium Mill Tailing Remedial Action) and management (e.g. waste storage, treatment, disposal and transportation) comply with the requirements of the National Environmental Policy Act and other related requirements before their implementation.

\section{Project Activities Division Robert H. Strickler, Director EH-252, Room GB-096B, Forrestal (202) $586-2410$}

Ensures that the Department's proposed projects and programs not involving waste as their principal focus comply with the requirements of the National Environmental Policy Act and other related requirements before their implementation.

\section{Office of the Deputy Assistant Secretary for Safety and Quality Assurance Joseph E. Fitzgerald, Jr., Deputy Assistant Secretary EH-30, Room 5129, 270 Corporate Center Germantown} (301) $903-5532$

Manages and directs comprehensive programs that assure non-nuclear safety in all DOE activities. Develops policies, standards, and guidance; provides technical assistance to line programs; conducts assessments to assure Departmental compliance with applicable national statutes, regulations, standards, and processes associated with worker safety; manages the Department's quality assurance and reliability program; manages the packaging and safety programs; and leads the Department's safety and health five-year planning activities.

\section{Resident Program Staff Bernard M. Hillman, Director EH-30.3, Room 5142, 270 Corporate Center Germantown (301) $903-3886$}


Maintains an on-site presence at key DOE sites and routinely monitors and audits the effectiveness of DOE and contractor line management in implementing programs to ensure the occupational safety and health of workers. Site representatives conduct management-level performance assessments and verify the effectiveness of safety and health programs for workers through selective observation of work place practices. The site representatives also monitor DOE and contractor responses to accidents, incidents, and other events.

\section{Office of Occupational Safety Roy E. Gibbs, Acting Director EH-31, Room 5096, 270 Corporate Center Germantown (301) 903-4343}

Develops and issues occupational safety policy, standards, and guides for DOE. Assists line programs in implementing and applying these policies and standards. Maintains functional expertise in all areas of occupational safety, including worker safety practices, fire protection, high explosives safety, industrial safety, and facility and construction safety. Also conducts safety information analyses and maintains a major computer system called Safety Performance Measurements System (SPMS).

\section{Policy and Standards Division Joseph A. Hopkins, Jr., Director EH-311, Room 5100, 270 Corporate Center Germantown (301) 903-5619}

Responsible for developing and coordinating Departmental policy, orders, standards, guides, and manuals in the areas of occupational safety and health programs and industrial safety. Tracks legislative issues affecting occupational safety. Primary liaison with the Occupational Safety and Health Administration in dealing with Memorandum of Understanding and jurisdiction issues. Provides support to the Annual DOE Occupational Safety Conference.

\section{Technical Support Division}

Ron D. Eimer, Acting Director

EH-312, Room 5095, 270 Corporate Center

Germantown

(301) 903-2927
Provides direct support and assistance to the DOE line programs in the establishment of Occupational Safety and Health (OSH) programs and the application of $\mathrm{OSH}$ requirements and standards. Develops $\mathrm{OSH}$ training requirements, model training programs, and supports pilot training within DOE on a cooperative basis with the DOE line programs and, where feasible, with the Occupational Safety and Health Administration and other agencies. Through experimental and demonstration programs, validates and expands DOE and contractor initiatives in key aspects of the OSH program (e.g., the Voluntary Protection Program, technical information exchange, and "model" compliance programs).

\section{Personnel Protection Division Michael C. Moore, Director EH-313, Room 5108, 270 Corporate Center Germantown (301) $903-5770$}

Maintains occupational safety technical expertise and provides consultative services to the Department's line programs and contractors in the safety-related areas of construction, electricity, firearms, fire protection, and high explosives. Provides technical assistance and supports projects for specific hazard identification and correction, and for the development and establishment of contractor safety programs.

\section{Safety Performance Indicator Division Steven Simon, Director EH-314, Room 5116, 270 Corporate Center Germantown \\ (301) 903-5615}

Conducts safety information analyses and manages an interactive computer system designed to furnish trend and causal factor analyses to assist in risk assessments, and to provide accident/incident information and Environment, Safety and Health technical information and communication throughout DOE. Publishes a quarterly newsletter, The Safety Connection, which provides new Departmental directions in occupational safety and health and highlights activities and programs related to occupational safety publications (e.g., Safety Notes, Bulletins, and Safety Actions) that disseminate safety and health information, as well as lessonslearned information across the DOE complex. 


\section{Office of Performance Assessment}

Oliver D. T. Lynch, Jr., Director

EH-32, Room 5019, 270 Corporate Center

Germantown

(301) 903-3548

Responsible for conducting safety performance assessments of DOE Government-owned, contractoroperated (GOCO) facilities (both nuclear and non-nuclear) to determine independently whether DOE's occupational and non-nuclear facility safety responsibilities are being properly fulfilled by responsible DOE line programs. Develops non-nuclear policy and assesses the effectiveness of Departmental quality assurance and reliability programs affecting contractor safety. Provides the key focus for EH on day-to-day operations and safety performance of DOE line organizations in the field; provides liaison with other EH offices; coordinates technical reviews of reports from and submittal to internal and external entities; and management-level oversight and special issue analysis. Responsible for the policy, implementation, and assessment of the DOE accident investigation program.

\section{Operations Management Division \\ Rebecca F. Hansen, Director \\ EH-321, Room 5016, 270 Corporate Center \\ Germantown}

(301) 903-5791

Through the operations managers who are assigned to major DOE sites, serves as the key focus for $\mathrm{EH}$ on day-to-day operations and safety performance of DOE and contractor line organizations in the field. Also provides management-level oversight and special issue analysis, and team leadership on oversight assessments of line operational readiness reviews.

\section{Performance and Quality Verification Division \\ John W. Teske, Director \\ EH-322, Room 5020, 270 Corporate Center Germantown \\ (301) 903-5607}

Develops procedures and conducts assessments of line management and organizational and staff effectiveness in implementing work place safety aspects of the DOE Occupational Safety and Health program. Also provides management and technical assistance to line programs. Responsible for $\mathrm{EH}$ accident investigation activities. Develops policy and provides management direction for the DOE occupational safety quality assurance program and assesses the effectiveness of line management implementation of that program.

\section{Office of Risk Analysis and}

Technology

Robert W. Barber, Director

EH-33, Room 5042, 270 Corporate Center

Germantown

(301) 903-3477

Responsible for the management and development of policy, oversight, and support functions of the Department that are related to facility safety analysis, transportation and packaging safety, and aviation safety. Plays a major role in developing Department policies and guidance to conduct analyses related to non-nuclear system safety. Provides oversight for issues related to nuclear and non-nuclear safety to ensure that safety functions are not compromised. Provides technical assistance to support line organizations in the implementation of their programs.

\section{Risk Analysis and Technology Division \\ Richard J. Serbu, Director \\ EH-331, Room 5043, 270 Corporate Center \\ Germantown}

(301) 903-2856

Provides oversight of Departmental non-nuclear safety and risk review processes, including natural phenomena hazards mitigation programs; develops policy, orders, guides, and standards; and provides technical assistance to line organizations in these areas. Program oversight responsibilities encompass hazards analysis, safety analysis, risk analysis and management, technical safety requirements, and safety evaluation for nuclear and non-nuclear facilities (including DOE dams) which are proposed, under construction, starting up, operating, restarting, or decommissioning. Coordinates EH activities related to cleanup worker safety and chemical safety.

\section{Transportation and Packaging Safety Division \\ Michael E. Wangler, Director \\ EH-332, Room 5034, 270 Corporate Center \\ Germantown}

(301) $903-5078$

Conducts technical analyses for hazards classification, operational controls, packaging, safety requirements, and training support for handling hazardous materials, including radioacti'e materials and explosives and aviation safety requirements. Conducts oversight and quality assurance reviews of the Department's transportation and packaging safety of hazardous materials. Performs technical safety analyses and evaluation reviews of line transportation systems. Assurance is provided that all transportation modes, including air, rail, highway, and water, provide safe 
movement of materials and personnel. To accomplish these activities, the Division develops training courses and standards for transportation safety. Certifies packaging for use by Department staff and contractors.

\section{Office of the Deputy Assistant Secretary for Health \\ Harry J. Pettengill, Deputy Assistant \\ Secretary \\ EH-40, Room 4119, 270 Corporate Center \\ Germantown}

(301) $903-7030$

Develops and recommends policies and standards related to radiation protection, industrial hygiene, and occupational medicine for DOE facilities. Maintains health surveillance data and conducts analyses through the implementation of an epidemiology program for DOE employees, contract workers, and communities adjacent to Departmental facilities; provides independent internal oversight to assure implementation of all aspects of DOE's occupational health programs; and assures funding of long-term analytical epidemiologic studies outside of DOE. Ensures communication for all health study findings to DOE employees, contractor employees, unions, and the public.

\section{Office of Health Physics and Industrial Hygiene \\ C. Rick Jones, Director \\ EH-41, Room 4011, 270 Corporate Center \\ Germantown \\ (301) 903-6061}

Develops and establishes policies and standards for all aspects of industrial hygiene and health physics. Provides independent internal oversight to assure implementation of industrial hygiene standards and policies. Responds to incidents and provides direct technical support to line programs. Maintains liaison with national and international standards organizations and directs a technology assessment outlay program to support new worker radiological health and industrial hygiene protection initiatives. Manages a health physics and industrial hygiene graduate fellowship program.

\section{Office of Epidemiology and Health Surveillance Robert Goldsmith, Director EH-42, Room 4079, 270 Corporate Center Germantown \\ (301) $903-5926$}

Responsible for all technical, research, policy development, and advisory and support functions in the Department related to health studies of human populations. The Office provides for the review and dissemination of information from epidemiologic activities; collects and maintains occupational and community health surveillance data; formulates programs and policies for managing health risks to workers at DOE facilities and to communities in the vicinity of these facilities; and develops and oversees preventive or protective measures baseci on the findings of epidemiologic studies for implemientation throughout the Department's operations.

\section{Office of Occupational Medicine George R. Gebus, Director EH-43, Room 4048, 270 Corporate Center Germantown (301) $903-7385$}

Develops policies and standards related to occupational medicine for the protection of workers and the public for utilization by DOE contractor facilities; protects and enhances the physical and mental health of all DOE contractor employees and promotes public health; provides for the internal assessment and oversight of contractor occupational medicine programs to assure implementation of standards and policies; and provides liaison and representation for national and international standards bodies for occupational medicine.

\section{ENERGY INFORMATION ADMINISTRATION (EIA) Office of the Administrator Jay E. Hakes, Administrator EI-1, Room 2H-027, Forrestal (202) 586-4361}

Responsible for the management of EIA, which collects, evaluates, and disseminates data pertaining to energy resources, reserves, production, and demand.

\section{Office of Oil and Gas Jimmie Petersen, Director EI-40, Room 2H-058, Forrestal (202) 586-6401}

Designs, develops, and maintains oil and gas statistical data and current and short-term analytical and forecasting information systems. The Office also performs data collection, quality control, processing analyses, short-term forecasting, and report preparation activities associated with these energy sources. 


\section{Petroleum Supply Division Charles C. Heath, Director EI-42, Room 2G-020, Forrestal (202) $586-6860$}

Designs, develops, and maintains statistical and shortterm forecasting information systems for crude oil and refined petroleum products. Performs data collection, processing, current analyses, and short-term forecasting, and report preparation activities associated with the availability of crude oil and refined petroleum products.

\section{Petroleum Marketing Division John S. Cook, Director EI-43, Room 2G-051, Forrestal (202) $586-5214$}

Designs, develops, and maintains crude oil and refined petroleum product price and marketing statistical information systems. Performs data collection, quality control, processing, current and short-term analyses and forecasting, and report preparation activities associated with crude oil and petroleum products markets.

\section{Reserves and Natural Gas Division Diane W. Lique, Director EI-44, Room BE-054, Forrestal (202) $586-6090$}

Designs, develops, and maintains statistical and shortterm forecasting information systems for domestic oil and gas reserves and production, and on the natural gas industry. Performs data collection, processing, analyses, short-term forecasting, and report preparation activities associated with oil and gas reserves and production, and all aspects of natural gas markets.

\section{Office of Coal, Nuclear, Electric and Altemate Fuels John C. Geidl, Director EI-50, Room 803, H Street (202) 254-5570}

Designs, develops, and maintains coal, nuclear, electric, and alternate fuels statistical and short-term forecasting information systems.

\section{Survey Management Division Howard L. Walton, Director EI-52, Room 703, H Street (202) 254-5500}

Designs, develops, and maintains coal, nuclear, electric and alternative fuels data collection surveys. Prepares publications containing these data and provides information for the National Energy Modeling System and other EIA forecasting models. Provides statistical interpretation, analyses, and support to other DOE offices, Federal agencies, Congress, and the public for these energy sources.

\section{Analysis and Systems Division Robert M. Schnapp, Director EI-53, Room 505, H Street (202) 254-5392}

Designs, develops, and maintains statistical information and short-term forecasting systems related to coal, nuclear, electric and alternate fuels. Assesses existing and potential resources and reserves, analyzes historical trends, produces forecasts for the short-term, performs quality control, and improves and maintains systems for data collection and analyses.

\section{Office of Energy Markets and End Use Webster C. Kilgore, Director EI-60, Room 2G-090, Forrestal (202) 586-1617}

Conducts analyses and provides short-term forecasts of energy markets. Monitors energy markets and maintains a contingency planning capability for use in case of emergency. Maintains integrated energy statistics and surveys energy consumption trends in each sector of the economy. Performs financial analyses of energy companies and tracks their investment trends. Designs, develops, and maintains energy statistical and short-term forecasting information systems concerning consumption and subjects which cut across energy sources.

\section{Energy Markets and Contingency Information Division Arthur T. Andersen, Director EI-62, Room 2G-060, Forrestal (202) 586-1441}

Performs analyses and short-term forecasting of world oil markets and energy demand patterns and prices and assesses the principal factors that affect these patterns. Acts as the center for the collection, analyses, and interpretation of enterprise-level financial and operating data within the ELA. Prepares and implements a program for the collection, evaluation, processing, and presentation of international energy data. 


\section{End Use and Integrated Statistics Division Lynda T. Carlson, Director EI-63, Room 2F-065, Forrestal (202) $586-1112$}

Designs, develops, tests, maintains, and documents energy consumption surveys and information systems which provide accurate and consistent data on energy end use in the residential, commercial, transportation, and industrial sectors. Provides monthly and annual integrated energy statistics for all sources of energy. Develops historical and current preliminary estimates of energy supply and disposition balances and energy prices and expenditures data and interprets trends and events.

\section{Office of Statistical Standards Yvonne M. Bishop, Director EI-70, Room 301, H Street (202) 254-5419}

Develops statistical policies for the EIA and provides technical assistance in survey design and statistical analyses. Assesses the quality and relevance of energy information and the processes used to collect, analyze, and forecast it. Coordinates EIA's statistical programs with the Office of Management and Budget, other Federal agencies, and academic and professional groups.

\section{Quality Assurance Division Douglas R. Hale, Director EI-72, Room 203, H Street (202) 254-5380}

Conducts data and model audits to assess the basic soundness of EIA's data systems and models; conducts data and model evaluations to assess the quality, relevance, and soundness of published statistics and the economic foundations of models and their mathematical and statistical properties; analyzes data systems and models and recommends improvements; compares EIA's data to other available data and, where applicable, identifies inconsistencies, the possible reasons, and solutions to address any problems; and conducts applied research in areas pertinent to the quality needs of EIA; and identifies needs for new standards or revisions to old standards and participates in their development and implementation.

\section{Data Collection Services Division John Gross, Director EI-73, Room 205, H Street (202) 254-5310}

Writes standards for ELA's data collection, processing, publication, analysis and forecasting activities; identifies need for changes to existing standards and prepares necessary standards and related materials; develops supplementary materials to assist BIA in standards-related areas; manages the public-use clearance process for the DOE's energy information collections; directs the energy information burden control program; maintains a glossary of energy and energyrelated terms and definitions for use by EIA; conducts various programs to assess standards compliance and recommends actions to achieve compliance; and maintains ELA's Data Resources Directory (DRD), and metadata system with descriptions of forms, models, systems, and energy-related terms and definitions.

\section{Office of Integrated Analysis and Forecasting Mary J. Hutzler, Director EI-80, Room 2F-081, Forrestal (202) $586-2222$}

Conducts forward-looking analyses and develops forecasts of alternative energy futures. Develops, applies, and maintains the National Energy Modeling System (NEMS) and other modeling systems needed to analyze and illuminate the complex interactions of the demand, conversion, and supply for all energy sources and their economic and environmental emplaces. Performs analytical studies of integrated energy markets and how they are affected by alternative energy policies and other parameters. Prepares midand long-term forecasts of energy markets, penetration of new technologies, and changes in energy, environmental, and macroeconomic policies and international developments. Publishes regular reports and special reports as requested. Coordinates with other EIA offices to maintain data systems needed for inputs to integrated analysis forecasting models and analyses.

\section{Energy Demand and Integration Division Mark E. Rodekohr, Director EI-81, Room 2F-081, Forrestal (202) $586-1130$}

Conducts forward-looking analyses of energy demand; generates mid-term and long-term forecasts of energy demand; and develops the demand components of the NEMS and other models dealing with the demand for energy services and energy consumption. 
149 Energy Supply and Conversion Division

Scott B. Sitzer, Director

EI-82, Room 2H-034, Forrestal

(202) 586-2308

Conducts forward-looking analyses of energy supply and conversion activities, including electricity and refining; generates mid-and long-term forecasts of energy supply and conversion; and develops the energy supply and conversion components for NEMS and other models dealing with production, distribution, and conversion of all energy sources.

\section{OFFICE OF THE ASSISTANT SECRETARY FOR ENVIRONMENTAL RESTORATION AND WASTE MANAGEMENT (EM) Thomas Grumbly, Assistant Secretary EM-1, Room 5A-014, Forrestal (202) $586-7710$}

Provides policy guidance and manages the cleanup of inactive waste sites and facilities, promulgates effective waste management operations, and implements an aggressive applied waste research and development program to provide permanent disposal solutions at reduced costs.

\section{Office of the Deputy Assistant Secretary for Oversight and Self Assessment Randal S. Scott, Deputy Assistant Secretary EM-20, Room 5B-024, Forrestal (202) 586-8754}

Performs internal oversight to assure proper application of environmental laws and regulations in connection with waste management operations, environmental restoration, and technology development activities managed and performed by line program offices.

\section{Office of the Deputy Assistant Secretary Waste Management Jill E. Lytle, Deputy Assistant Secretary EM-30, Room 5B-040, Forrestal (202) $586-0370$}

Responsible for all DOE facilities, operations, or sites that are used for the storage, treatment, or disposal of radioactive, hazardous waste materials that have been packaged and labeled, or used exclusively for longterm storage of DOE waste materials. Excepted are facilities, operations, or sites under the direction of the
DOE Office of Civilian Radioactive Waste Management.

\section{Office of Waste Operations Lawrence H. Harmon, Acting Director EM-32, Room 340 12800 Middlebrook Road Germantown, MD 20874 (301) 903-7105}

Responsible for programs involving waste management at DOE sites, including treatment, storage, transportation, and disposal of high-level, transuranic, and low-level radioactive waste; hazardous waste; mixed radioactive and hazardous waste; and sanitary waste in compliance with Federal, State, and local regulations and DOE Orders.

\section{Office of Program Support, Waste Management James A. Turi, Director EM-33, Room 376 12800 Middlebrook Road Germantown, MD 20874 (301) 903-7147}

Provides administrative management and financial support to the line organizations that comprise the Office of Waste Operations.

\section{Office of Waste Management Projects Mark W. Frei, Director EM-34, Room 323, 12800 Middlebrook Road Germantown, MD 20874 \\ (301) 903-7201}

Responsible for planning, design, construction, and initial operation of projects for waste treatment, storage, and disposal. - This includes major system acquisitions and other construction projects to support waste management operations.

\section{Office of Technical Support Joseph A. Coleman, Director EM-35, Room 377 12800 Middlebrook Road Germantown, MD 20874 (301) $903-7410$}

Responsible for activities supporting waste management operations at multiple sites. Also responsible for planning and coordinating waste minimization activities at DOE sites. 


\section{Office of the Deputy Asoiatant \\ Secretary for Environmental \\ Restoration \\ Roger P. Whitfield, Deputy Assistant \\ Secretary \\ EM-40, Room 5B-050, Forrestal \\ (202) 586-6331}

Manages programs to ensure that risks to human health and the environment posed by DOE's past operations at its nuclear facilities and sites are eliminated or reduced to prescribed, safe levels. Assesses and cleans up these sites and facilities contaminated with radioactive, hazardous, and mixed waste.

\section{Office of Eastem Area Programs \\ James J. Fiore, Director \\ EM-42, Room 104 \\ 12800 Middlebrook Road \\ Germantown, MD 20874 \\ (301) 903-8141}

Manages remedial actions at inactive sites and surplus DOE facilities and the decontamination and decommissioning programs implemented in the operations offices in Chicago, Oak Ridge, and Savannah River.

\section{Office of Program Support, Environmental Restoration William Wisenbaker, Jr., Director \\ EM-43, Room 209 \\ 12800 Middiebrook Road \\ Germantown, MD 20874 \\ (301) 903-8105}

Provides administrative, management, and financial support to line organizations that comprise the Office of Environmental Restoration.

\section{Office of Northwestern Area Programs Sally A. Mann, Director \\ EM-44, Room 156 \\ 12800 Middlebrook Road \\ Germantown, MD 20874 \\ (301) 903-8161}

Provides direction and oversight of remedial actions at inactive sites and surplus DOE facilities and manages the decontamination and decommissioning programs implemented in the operations offices in Idaho, Richland, and San Francisco.

\section{Office of Southwestern Area Programs Ralph G. Lightner, Director EM-45, Room 145 12800 Middlebrook Road Germantown, MD 20874 (301) 903-8180}

Provides direction and oversight of remedial actions at inactive sites and surplus DOE facilities and manages the decontamination and deconumissioning programs implemented in the operations offices in Albuquerque, New Mexico, and Nevada.

\section{Office of the Deputy Assistant Secretary for Technology Development Clyde W. Frank, Deputy Assistant Secretary EM-50, Room 5A-014, Forrestal (202) $586-6382$}

Manages and directs programs and activities to establish and maintain an aggressive national program for applied research and development to resolve major technical issues and rapidly advancing current rechnologies for environmental restoration and waste management operations.

\section{Office of Technology Integration and Environmental Education and Development Susan M. Prestwich, Director EM-52, Room 432 12800 Middlebrook Road Germantown, MD 20874 (301) 903-7924}

Responsible for programs and activities which survey and compare DOE's human resource needs (number and skill $\mathrm{mix}$ ) relative to waste operations management and environmental restoration against the current resource base and develops innovative methods to develop management programs needed for future environmental programs.

\section{Office of Program Support and Technology Development Gerald G. Boyd, Acting Director EM-53, Room 470 12800 Middlebrook Road Germantown, MD 20874 (301) 903-8621}

Provides administrative, management, and financial program support to line organizations that comprise the Office of Technology Development. 


\section{Office of Research and Development \\ Stephen C. T. Lien, Direstor \\ EM-54, Room 412 \\ 12800 Middlebrook Road \\ Germantown, MD 20874 \\ (301) 903-7911}

Responsible for the development of an applied research and development program at DOE sites across the Nation. Programs will be designed to identify operational needs in the areas of environmental restoration and waste management operations beyond currently available technologies and to provide solutions to key technical issues that, if not solved in a timely manner, will adversely affect DOE's ability to meet its 30-year cleanup goal.

\section{Office of Demonstration Testing and Evaluation \\ William C. Schutte, Acting Director \\ EM-55, Room 407 \\ 12800 Middlebrook Road \\ Germantown, MD 20874 \\ (301) $903-8490$}

Responsible for the identification of technologies in the research and development stage that are amenable to transition to technology demonstration projects.

\section{Office of Special Programs \\ Richard W. Brancato, Director \\ EM-56, Room 461 \\ 12800 Middlebrook Road \\ Germantown, MD 20874 \\ (301) 903-7278}

Responsible for supporting programs and activities that crosscut all offices within EM in the areas of transportation management, emergency management, laboratory analysis of samples, and liaison and communications support. In transportation management and transportation energy management, responsibilities are DOE-wide.

\section{OFFICE OF ENERGY RESEARCH (ER) Office of Energy Research Martha A. Krebs, Director ER-1, Room 7B-058, Forrestal (202) $586-5430$}

Carries out a broad range of advisory, coordination, and program management activities related to the Department's energy research and development mis- sions. Supports a broad spectrum of research in the basic energy sciences, high energy and nuclear physics, magnetic fusion energy, and biomedical and environmental sciences. Advises the Secretary on science and technology policy; assesses DOE's R\&D programs for duplication or gaps; and serves as focal point for coordination with other agencies in science and technology.

\section{Office of Assessment and Support Joseph R. Maher, Director ER-8, Room E-240, Germantown (301) 903-4097}

Plans, develops, manages, and implements a central energy research environmental protection, safety, and health protection (ES\&H) technical support program. The overall purpose and aim of this program is to ensure protection of the environment and the health and safety of the public, provide a safe and healthful work place, and protect Government property against accidental loss and damage.

\section{Safety and Health Protection Division Walter N. Thomasson, Acting Director ER-8.1, Room E-239, Germantown} (301) 903-2092

Provides oversight and technical support to Energy Research program offices on matters related to the safe design, construction, operation, and modification of Energy Research-funded facilities, focusing on engineering systems and the man-machine interface.

\section{Environmental Division}

James K. Farley, Acting Director ER-8.2, Room G-414, Germantown (301) 903-2314

Provides technical support to program offices on matters related to environmental protection, waste management, the packaging and the transporting of hazardous materials, and the National Environmental Policy Act.

\section{Office of Basic Energy Sciences Vacant, Associate Director ER-10, Room J-304, Germantown (301) $903-3081$}

Manages a basic research program covering a broad spectrum of scientific disciplines, which produces sci- 
entific and technical knowledge needed to develop future energy technology options; supports research leading to new materials, processes, instruments, and techniques useful in energy technologies; explores advanced energy concepts not currently included within Departmental energy technology organizational components; contributes to the base of fundamental science in the United States; provides and safely operates national advanced research facilities.

\section{Material Sciences Division Iran L. Thomas, Director ER-13, Room J-317, Germantown (301) 903-3427}

Funds and administers Metallurgy and Ceramics Research programs in the preparation and study of properties of new materials for improvement and control of chemical composition and structure; controlling, predicting and changing mechanical, surface, and other physical properties; and controlling properties of engineering materials and the effects of radiation. Also funds and administers Solid State Physics and Materials Chemistry Research programs in superconductivity, neutron scattering, new materials preparation, experimental studies, and theoretical modeling of optical, thermal, electronic, magnetic, and other properties of solids, engineering physics, high temperature and surface properties of solids, mass transport, chemical structure, and engineering chemistry.

\section{Chemical Sciences Division Robert S. Marianelli, Director ER-14, Room G-334, Germantown (301) 903-5804}

Funds and administers the programs of the most basic and long-range energy-related chemical sciences research areas (e.g., photochemistry, radiation chemistry, hot atom chemistry, chemical dynamics, theoretical chemistry, many types of spectroscopy, and the physics of ions, atoms and molecules). Funds and administers programs that emphasize research in areas of chemical sciences needed to lead and assist in the advanceinent of energy technologies (e.g., the chemistry of various types of coals; heterogeneous and homogeneous catalysis; chemical thermodynamics; actinide chemistry; chemical basics of converting carbohydrates to liquid and gaseous fuels; separation of fuel substances before and after use; analytical chemistry; and chemical engineering sciences, such as dynamics of fluidized bed combustion). The Division funds and operates major user facilities providing unique capabilities for researchers.

\section{Engineering and Geosciences Hivision James S. Coleman, Director ER-15, Room G-363, Germantown (301) $903-5822$}

Supports the Department's central fundamental research activities in the engineering and geoscience disciplines conducted by universities, Federal laboratories, and industrial firms throughout the United States. In engineering research, emphasis is given to analysis, control, and improvement of systems for transport of heat and fluids and for materials processing. In geoscience research, emphasis is given to the geophysics and geochemistry of rock/fluid systems.

\section{Advanced Energy Projects Division Walter M. Polansky. Director ER-16, Room G-347, Germantown (301) 903-5995}

Supports novel and untested energy-related concepts that emerge from advances in basic research, as well as research activities which do not fit easily into or qualify for support by an existing DOE technology program and for which longer term studies and experiments are required prior to the commitment of largescale Government funding. Manages the Department's Small Business Innovation Research Program required by the Small Business Innovation Development Act (Public Law 97-219), which mandates a uniformly structured three-phase research and development program to strengthen the role of small, innovative firms in Federally funded research and development.

\section{Energy Biosciences Division Robert Rabson, Director ER-17, Room G-358, Germantown (301) $903-2873$}

Funds and administers research activities of the Energy Biosciences subprogram conducted in universities, National laboratories, nonprofit institutions, and industry. Funds fundamental research in the plant and microbial sciences that will underpin new biotechnologies relating to energy matters. Coordinates research efforts in energy bioscience matters with those of other DOE elements through the Bioenergy Coordinating Committee. 


\section{Office of High Energy and Nuclear Physics \\ Wilmot N. Hess, Associate Director \\ ER-20, Room G-304, Germantown \\ (301) $903-3713$}

Provides effective planning, funding, and management of the Department's High Energy Physics and Nuclear Physics Research programs. Assists the Director of ER in the establishment of research policies for these areas of basic sciences and funds meritorious research programs at Federal laboratories, universities, and industrial institutions. Provides scientific and technical knowledge for development of technology options and technology transfer of those projects which show high promise of becoming important as energy technologies. Develops and executes procedures to ensure that the Nation's high energy and nuclear physics facilities are operated efficiently and reliably to meet the research needs of the near future and to ensure that new or upgraded facilities are designed and constructed as needed for the future health and vitality of these fields. Pursues international collaboration in all phases of high energy and nuclear physics.

\section{High Energy Physics Division John R. O'Fallon, Director ER-22, Room F-338, Germantown (301) 903-3624}

Funds and administers the DOE-sponsored research efforts in high energy physics conducted in universities, Federal laboratories, and industrial organizations. Serves as Executive Agent for the U.S. High Energy Physics Program. Maintains liaison and coordinates the U.S. High Energy Physics program with those of other nations and assists in the formulation and administration of formal international agreements of collaboration with other nations.

\section{Nuclear Physics Division David L. Hendrie, Director ER-23, Room G-307, Germantown (301) $903-3613$}

Funds and administers the Nuclear Physics Program conducted in universities and Federal laboratories in the areas of medium energy and heavy ion nuclear physics, nuclear theory, low energy nuclear research, nuclear data measurements, and compilation and evaluation of nuclear data.

\section{Office of Scientific Computing David B. Nelson, Associate Director ER-30, Room J-123, Germantown (301) $903-5800$}

Ensures the broad range of research in the mathematical and computer science fields necessary to underpin all of the other energy sciences and manages an international data communications network which provides state-of-the-art supercomputing facilities for ER contractors in universities, industry, and DOE laboratories. Carries out DOE's role as lead Federal agency for the acceleration of supercomputer development.

\section{Office of Program Analysis George Y. Jordy, Director ER-41, Room G-415 Germantown (301) 903-2971}

Monitors the Department's R\&D programs and provides, on a periodic or as requested basis, independent and objective program analyses and technical assessments. Provides Departmental oversight, coordination and review of acid rain research, including the activities of the interagency National Acid Precipitation Assessment Program (NAPAP).

\section{Research and Technical Assessment Division Robert G. Rader, Director ER-411, Room G-414, Germantown (301) 903-2651}

Selects, supports, and manages assessments of research needs and technical opportunities to provide expert technical consultation and assistance in support of the assessments conducted by the Office of Program Analysis. Using peer reviews or assessments of ongoing DOE R\&D programs, measures the quality and impact and estimates their technical potential.

\section{Program Integration Analysis Division Walter L. Warnick, Director ER-412, Room G-410, Germantown (301) 903-3122}

Conducts analyses of DOE R\&D program goals and milestones and provides recommendations of prioritized research needs for energy technology programs. Evaluates the scientific underpinnings of studies having policy significance. Coordinates DOE involvement in interagency crosscutting science and technology areas, such as environmental science. 


\section{Office of Fusion Energy}

Nelia A. Davies, Associate Director

ER-50, Room J-204, Germantown

(301) 903-4941

Supports the Director of ER by managing programs related to the development of the scientific and technological base for fusion energy; interprets policy guidance and suggests policy revisions; develops and evaluates program and budget strategies, priorities, and plans encompassing scientific and technical program content, goals, and objectives, including institutional plans. Pursues international collaborations in research and in new, large facilities which may be too costly for any one country.

\section{International Programs Staff Michael Roberts, Director ER-52, Room J-225, Germantown (301) 903-3068}

Develops and implements policies, plans, and strategies, and formulates the goals and objectives of international collaborations. Directs overall activities for the development of major joint projects, including the four-party International Thermonuclear Experimental Reactor (ITER) activities and technical exchange programs.

\section{International Thermonuclear Experimental Reactor and Technology Division Thomas R. James, Acting Director ER-53, Room J-208, Germantown (301) $903-5378$}

Manages and provides technical direction for the U.S. International Thermonuclear Experimental Reactor (ITER) program, as well as managing the U.S. fusion base technology development program for near-term experimental needs. Develops the technologies needed to form, contain, heat, and sustain a reacting fusion plasma, including magnetic, heating, and fueling systems. This Division also focuses on elements of fusion devices related to long-term waste issues, safety and environmental considerations, device reliability, tritium production and power extraction.

\section{Advanced Physics and Technology Division David H. Crandall, Director ER-54, Room G-242, Germantown (301) $903-4596$}

Undertakes theoretical and small-scale experimental studies of fusion plasma phenomena and basic issues needed to predict thermonuclear plasma behavior in confinement experiments and future fusion power systems. Supports and assesses the development of promising improvements to plasma configurations, and develops new diagnostic techniques needed to study plasma phenomena in support of magnetic and inertial confinement systems. Focuses on key technology elements of fusion devices and elements related to materials development. Supports examinations of proposed structural materials, low activation materials, and diverter materials. Conducts reactor studies to model future fusion power systems, to identify issues, and to provide future program direction.

\section{Confinement Systems Division John W. Willis, Director ER-55, Room G-250, Germantown (301) $903-4095$}

Manages a program of medium-to-large fusion research experiments operating at reactor level plasma parameters. Emphasizes the resolution of key physics issues which are critical to the continued development of improved magnetic confinement systems leading to a practical fusion energy source.

\section{Office of Health and Environmental Research \\ Aristides A. Patrinos, Acting Associate Director \\ ER-70, Room G-165, Germantown (301) $903-3251$}

Manages basic and applied research programs to achieve understanding of health and environmental effects associated with energy technologies and to advance technological solutions for major problems in biology, medicine, and environmental science-related issues. Supports research conducted in the Department's National laboratories, as well as in the university and private sector, in atmospheric, marine, and terrestrial processes, including the linkage between the rise in greenhouse gases, e.g., carbon dioxide, and regional and global climate change; molecular and subcellular mechanisms underlying human somatic and genetic processes and their responses to environmental toxicants; nuclear medicine, structural biology, the human genome, measurement sciences and instrumentation; and other areas that require the unique capabilities of the DOE laboratory system. 


\section{Health Effects and Life Sciences \\ Research Division \\ David A. Smith, Director \\ ER-72, Room G-155, Germantown \\ (301) $903-5468$}

Conducts research in selected experimental animal, cellular, and molecular model systems for evaluating the potential adverse health effects, such as carcinogenesis and mutagenesis and developmental effects that could result from exposures to radiation and chemical agents relevant to DOE programs. Supports general life sciences research to provide the base of fundamental biological knowledge that is required for the effective study and interpretation of energy-related health effects. Supports the technology development and computational biology for mapping and sequencing the human genome and optimizing the Department's capability for conducting structural biology research.

\section{Medical Applications and Biophysical Research Division Robert W. Wood, Director ER-73, Room G-146, Germantown (301) 903-3213}

Conducts research on advanced radiation and chemical dosimetry techniques. Pursues instrumentation research and development to acquire improved analytical measurement technology. Supports radiological physics research to provide fundamental insights into the interaction of radiation with biological systems. Conducts medical research to develop new radioisotope and radio-pharmaceutical applications for diagnosis and therapy, advanced imaging instrumentation, and new radiation treatment approaches. Supports molecular nuclear medicine research which brings the insights and technology from molecular biology to achieve advanced nuclear medicine methodology.

\section{Environmental Sciences Division Aristides A. Patrinos, Director ER-74, Room G-156, Germantown (301) 903-3281}

Conducts research on environmental processes and effects to address the transport and transformation of energy-related pollutants through atmospheric, marine, and terrestrial ecosystems; ecosystem responses and the mechanisms that control them; advanced concepts for waste cleanup; processes involved in stratospheric ozone depletion; and the role of molecular biology in understanding the oceanic, terrestrial, and surface ecosystem responses. Conducts a carbon di- oxide program to establish the quantitative links between the rise of greenhouse gases and global warming, including studies to understand ocean circulation and the exchange of $\mathrm{CO}_{2}$ between the open ocean and the atmosphere.

\section{Office of Superconducting Super Collider James C. Hall, Associate Director ER-90, Room H-262, 2550 Beckleymeade Av- enue (MS-1020) \\ Dallas, TX 75237 \\ (214) 708-2521}

Provides technical, managerial, and administrative oversight of the Superconducting Super Collider (SSC) program and project activities, including research, construction, operation, and maintenance of the multibillion dollar SSC. Provides the program and project guidance and funding to meet the numerous complex requirements of the program, including research and development; design, construction, operation, and maintenance of the accelerator; compliance with ES\&H regulations; international collaborations; Texas interactions; and liaison with State and local governments, universities, industry, the public, media, and Congress.

\section{Office of Science Education and Technical Information (ET)}

\section{Office of University and Science Education Programs Richard E. Stephens, Director ET-30, Room 3F-043, Forrestal (202) 586-8949}

Coordinates and administers the implementation of all Departmental programs in science, mathematics and engineering education at the precollege and university levels. Provides policy guidance and administrative direction to the University and Science Education program, the University Reactor Fuel Assistance program, and the University Research Instrumentation program.

\section{Postsecondary Programs Division Vacant, Director ET-31, Room 5B-168, Forrestal (202) 586-8949}

Administers partnership programs among the Department, its laboratories, other Federal agencies, universities, and industry to enhance postsecondary science, mathematics, and engineering education. 


\section{Precollege Programs Division Vacant, Director ET-32, Room 6E-050, Forrestal (202) $586-6833$}

Administers partnership programs among the Department, its laboratories, other Federal agencies, universities, and industry to enhance precollege science and mathematics education. Plans and directs the evaluation of precollege science and mathematics education programs.

\section{OFFICE OF THE ASSISTANT SECRETARY FOR FOSSIL ENERGY (FE) \\ Jack S. Siegel, Acting Assistant Secretary \\ FE-1, Room 4G-084, Forrestal \\ (202) $586-6660$}

Oversees the research, development and demonstration of advanced, innovative technologies that can (1) enhance the Nation's production and use of natural gas, (2) increase the effectiveness of crude oil exploration and recovery processes, and (3) improve the environmental acceptability and economic performance of energy production from the U.S.'s abundant coal reserves. Manages the Strategic Petroleum Reserve, the Nation's emergency crude oil stockpile; the production and commercial sale of crude oil, natural gas, and petroleum products from the Naval Petroleum Reserves; and administration of certain regulatory functions, including authorizations and permits for natural gas imports and exports, electricity exports, and international powerline facilities.

\section{Office of Planning and Environment Raymond J. Braitsch, Jr., Acting Director FE-4, Room 4G-067, Forrestal (202) $586-4426$}

Oversees preparation of strategic planning issues and translates DOE policies into fossil energy programmatic guidance. Develops the overall FE program strategy and maintains crosscutting technical and economic data bases. Coordinates FE's participation in DOE-wide technical and policy issues, such as acid deposition, global climate change, and general environmental, economic, and energy impacts associated with different policy options. Oversees fossil fuel export activities, including the coal and coal technology export program, which promotes the marketing of U.S. coal and coal utilization technologies in international markets.
200 Office of Communications

Robert C. Porter, Director

FE-5, Room 4G-085, Forrestal

(202) $586-6503$

Coordinates FE's communications with external stakeholders, including the general public, business and industry, Congress, and educational institutions. Maintains several publicly accessible, automated information services, including an on-line computer bulletin board (Fossil Energy Telenews, 202-586-6496) and a telephone dial-in fax service (Fossil Energy TechLine, 202-586-4300). Oversees the preparation and distribution of Fossil Energy pamphlets, fact sheets, audiovisual materials, and educational information. The Office also provides Federal administrative support for the two principal fossil energy advisory committees, the National Petroleum Council and the National Coal Council, and maintains FE's correspondence control functions.

\section{Office of Self Assessment Craig D. Zamuda, Director FE-6, Room 3E-042, Forrestal (202) 586-6241}

Assures that FE's Federal and contractor operations comply with the Department's environment, safety and health, and safeguards/security guidelines and requirements. Performs independent appraisals of FE facilities to ensure that proper attention is being provided to the health and safety of employees and the general public, as well as to the protection of the environment. Assesses the adequacy of training programs for FE program personnel responsible for these functions.

\section{Office of the Deputy Assistant Secretary for Management Jeremiah E. Walsh, Jr., Deputy Assistant Secretary FE-10, Room 3049, 270 Corporate Center, Germantown}

(301) 903-2617

Responsible for the budget and administrative and management activities for all FE programs. Functions include program evaluations, business operations, international affairs policy and management, and the development of general FE-wide technology transfer policies. 
203 Office of Resource Management Gene H. Kight, Director FE-12, Room 3086, 270 Corporate Center Germantown

(301) 903-6841

Oversees the preparation of FE budgets and the management of its human and financial resources. Develops fiscal policy, manages financial plans and allotments, and certifies availability of funding. Oversees management information and other automated data processing systems and manages crosscutting FE contractor support activities.

\section{Office of Business Operations \\ Keith N. Frye, Director \\ FE-13, Room 3051, 270 Corporate Center \\ Germantown \\ (301) 903-2098}

Conducts business-related activities for the FE, including the development of policy guidance for joint ventures, cooperative research and development agreements, international agreements, cost-shared partnerships, and other joint activities with commercial businesses and research institutions. Oversees DOE's operation of the Liquefied Gaseous Fuels Spill Test Facility, a user facility available to industry for studying the effects of, and mitigation strategies for, the accidental release of hazardous substances used in commercial operations. Coordinates FE's research and training programs for Historically Black Colleges and Universities and serves as a coordinator of FE's activities with Native Americans. Provides support for energy emergency preparedness and defense-related strategies and programs.

\section{Office of the Deputy Assistant Secretary for Coal Technology Jack S. Siegel, Deputy Assistant Secretary FE-20, Room 4G-052, Forrestal (202) $586-1650$}

Oversees the research, development, and demonstration of advanced, environmentally cleaner, more efficient technologies for using the Nation's coal resources.

\section{Office of the Associate Deputy} Assistant Secretary for Clean Coal Clarence L. Miller, Associate Deputy Assistant Secretary

FE-22, Room 3111, 270 Corporate Center Germantown

(301) $903-9451$
Manages DOE's Clean Coal Technology Demonstration Program, a multi-billion dollar Government-industry partnership formed to build and test innovative coal technologies that are approaching the commercial threshold. The Clean Coal Technology Demonstration Program has resulted, to date, in 46 commercial or near-commercial scale projects representing a public-private investment of more than $\$ 6.8$ billion. Included are technologies that can (1) generate electricity from coal more efficiently and with far fewer pollutants than is possible with today's processes; (2) be retrofitted to existing power stations to reduce emissions; (3) convert coal to cleaner, more useable fuel forms; and (4) provide new, cleaner, and more economical processes for such coal-based industrial operations as steelmaking and cement production.

\section{Office of the Associate Deputy Assistant Secretary for Research and Development George Rudins, Associate Deputy Assistant Secretary FE-23, Room 3013, 270 Corporate Center Germantown (301) $903-3991$}

Manages the research and development of future generations of coal-based technologies that are in the laboratory or early engineering stages. Included are advanced concepts for fluidized bed coal combustion, low emission boiler systems, indirectly fired power generating cycles, gasification-combined cycle systems, processes for converting coal into liquid products, and supporting research in such areas as coal preparation, gas cleanup, waste management, and alternative, coal-based fuels. Oversees program to develop a high efficiency, advanced gas turbine.

\section{Office of the Deputy Assistant Secretary for Gas and Petroleum Technology Reginal W. Spiller, Deputy Assistant Secretary FE-30, Room 4G-084, Forrestal (202) $586-4695$}

Manages DOE's programs to develop and deploy improved technologies to extract and process natural gas and crude oil, focusing primarily on assisting domestic producers in adapting new techniques that can prolong the economic life of U.S. oil fields and that can create new opportunities for the production and use of natural gas. 


\section{Office of Oil and Gas Processing Sandra L. Waisley, Acting Director FE-32, Room 3E-042, Forrestal (202) 586-7361}

Responsible for the development of research and development programs related to processing technologies for oil and gas. Courdinates strategic plans to ensure that the oil processing, gas delivery and storage, and gas utilization needs of the energy industry are met. Activities include development of improved heavy oil upgrading technologies, gas-to-liquid conversion processes, and natural gas deliverability and storage techniques.

\section{Office of Oil and Gas Exploration and Production Donald A. Juckett, Director FE-33, Room 3E-028, Forrestal (202) $586-5600$}

Responsible for programs intended to develop improved techniques for the exploration and production of oil and natural gas. Oversees a nationwide field program that is demonstrating more effective means for locating and producing missed or bypassed oil in U.S. reservoirs threatened with near-term abandonment. Manages a crosscutting research program in which new techniques are being developed to produce potentially billions of barrels of domestic crude oil unrecoverable with today's technology. Oversees programs to develop more effective ways to extract natural gas from both conventional and nonconventional deposits. Develops environmental data and mitigation techniques for oil and gas production.

\section{Office of the Deputy Assistant Secretary Strategic Petroleum Reserve Richard D. Furiga, Deputy Assistant Secretary FE-40, Room 3G-024, Forrestal (202) $586-4410$}

Responsible for the Strategic Petroleum Reserve, the Nation's emergency crude oil stockpile. The Strategic Petroleum Reserve is a complex of underground salt dome storage facilities sited along the Texas-Louisiana Gulf Coast. The storage facilities are connected to both private and Government-owned commercial oil distribution facilities. Crude oil can be withdrawn from the Reserve upon Presidential order to counter an energy supply disruption.

\section{Office of Technical Management \\ Paul J. Plaisance, Jr., Director FE-42, Room 3G-070, Forrestal (202) $586-4415$}

Oversees the operation of the Strategic Petroleum Reserve, including the management and operating contracts and numerous subcontracts. The Office is responsible for planning, engineering, quality assurance, and other operational aspects of the Reserve. Serves as Headquarters commander for any catastrophic incidents/accidents, with responsibility for disaster response planning.

\section{Office of Management Operations Howard G. Borgstrom, Director FE-43, Room 3G-038, Forrestal (202) 586-4421}

Oversees the preparation of long-term, strategic, and financial analyses that play a role in determining the appropriate size and capabilities of the Strategic Petroleum Reserve. This Office maintains crude oil market and refinery modeling capabilities, prepares policy and legislative analyses, and provides budgeting support for the Reserve.

\section{Office of the Deputy Assistant Secretary for Fuels Programs Vacant, Deputy Assistant Secretary FE-50, Room 3H-087, Forrestal (202) $586-9482$}

Responsible for several Federal regulatory functions involving coal, natural gas, and electricity.

\section{5 office of Coal and Electricity Anthony J. Como, Director FE-52, Room 3H-087, Forrestal (202) 586-5935}

Responsible for processing applications for the export of electricity and for the construction and operation of the attendant international transmission facilities. Prepares coal conversion orders to certify powerplants under the Powerplants and Industrial Fuel Use Act of 1978 (FUA), as amended, and the Energy Supply and Environmental Coordination Act of 1974. Processes petitions for exemptions from the prohibitions of the FUA. 


\section{Office of Natural Gas Clifford P. Tomaszewski, Director FE-53, Room 3H-087, Forrestal (202) $586-9482$}

Performs policy analysis and case management functions relative to the import and export of natural gas. Provides the Department's regulatory interface with the State Department, Federal agencies, international affairs and policy offices, and foreign governments regarding U.S. natural gas import and export policies. Processes applications to import or export natural gas, including the review of environmental impacts associated with applications.

\section{Office of the Deputy Assistant Secretary for Naval Petroleum and Oil Shale Reserves \\ Kenneth W. Meeks, Deputy Assistant \\ Secretary \\ FE-60, Room 3H-076, Forrestal \\ (202) 586-4685}

Manages the operations of the commercial oil fields that make up the Naval Petroleum Reserves and also oversees the Government's ownership of the Naval Oil Shale Reserves. The Naval Petroleum Reserves were originally created in the early 1900 's to provide sources of liquid fuels for the Armed Forces during national emergencies. However, the competitive sale of hydrocarbon products on the open market now provides revenue to the U.S. Treasury. The Naval Petroleum and Oil Shale Reserves consist of three petroleum reserves and three oil shale reserves. Naval Petroleum Reserve No. 1 (NPR-1), Elk Hills, located 35 miles west of Bakersfield, California, is jointly owned and operated by the Government and Chevron U.S.A., Inc. Naval Petroleum Reserve No. 2 (NPR-2), Buena Vista Hills, is adjacent to NPR-1 and is leased to private industry. Naval Petroleum Reserve No. 3 (NPR3), Teapot Dome, 35 miles north of Casper, Wyoming, is wholly owned and operated by the Federal Government. Naval Oil Shale Reserve No. 1 (NOSR-1) and Naval Oil Shale Reserve No. 3 (NOSR-3) are adjacent tracts of land in western Colorado. Naval Oil Shale Reserve No.2 (NOSR-2) is located in northeastern Utah.

218 Office of the Deputy Assistant

Secretary for Advanced Research and Special Technologies

Marvin I. Singer, Deputy Assistant Secretary FE-70, Room 4G-052, Forrestal

(202) 586-1577

Responsible for the development of fuel cells and magnetohydrodynamics technologies along with ex- traction technologies for oil shale, and for overseeing FE's crosscutting advanced research programs in coal, oil, and natural gas.

\section{Office of Advanced Research David J. Beecy, Director FE-72, Room 3047, 270 Corporate Center Germantown \\ (301) 903-2787}

Manages FE's advanced research programs in coal, oil, and gas. Oversees the University Coal Research Program, which provides grants to student-teacher research teams. Coordinates FE's involvement in specialized programs, such as the Small Business Innovation Research (SBIR) program and serves as coordinator for materials research and biotechnology.

\section{Office of Special Technologies \\ Victor K. Der, Director \\ FE-73, Room 3014, 270 Corporate Center Germantown \\ (301) 903-2700}

Directs the development of natural gas- and coal-fueled fuel cells for the stationary electric power generation market. Oversees the Government's involvement in the magnetohydrodynamics program, an advanced concept for generating electricity from coal. Manages the Department's efforts in extracting oil from shale.

\section{Office of the General Counsel (GC)}

\section{Economic Regulatory Administration Jerry F. Thompson, Acting Director GC-60, Room 826, Union Center Plaza Washington, DC 20002 (202) 523-3053
Office of Enforcement Litigation Milton C. Lorenz, Director GC-62, Room 834, Union Center Plaza Washington, DC 20002 (202) 523-3011

Responsible for all Emergency Petroleum Allocation Act (EPAA) related litigation and litigation audit support activities. This includes administrative litigation conducted before the Office of Hearings and Appeals and the Federal Energy Regulatory Commission and judicial litigation conducted before Federal courts. (In most cases, DOE has primary litigation responsibility in the Federal courts.) This Office acts as the Economic Regulatory Administration's principal liaison with 
the Department of Justice. In addition, this Office is responsible for the conduct of all efforts to resolve enforcement matters through negotiation, maintenance of the audit program, and supervision of field operation.

\section{Administrative Litigation Division Diana D. Clark, Director GC-621, Room 843, Union Center Plaza Washington, DC 20002 \\ (202) 523-3048}

Justifies, supports, and defends all enforcement actions concerning compliance with EPAA regulations before the Office of Hearings and Appeals and the Federal Energy Regulatory Commission. This includes crude oil producer and reseller regulations, refiner pricing regulations, transfer pricing regulations, entitlement, tertiary incentive, and product reseller regulations. Coordinates with other divisions of the Office of Enforcement Litigation to ensure use of appropriate strategies and tactics and to ensure uniform enforcement goals and procedures.

\section{Judicial Litigation Division \\ Don W. Crockett, Director \\ GC-622, Room 825, Union Center Plaza \\ Washington, DC 20002 \\ (202) 523-3089}

Enforces and defends regulatory programs and orders in all Emergency Petroleum Allocation Act-related Federal court civil litigation involving the Department. Litigates all aspects of cases brought against the Department, including appeals to the U.S. Court of Appeals.

\section{OFFICE OF HEARINGS AND APPEALS (HG) George B. Breznay, Director HG-1, Room 6G-030, Forrestal (202) $586-5510$}

Responsible for conducting hearings and issuing the initial decision of the Department with respect to any adjudicative proceedings which the Secretary may delegate, except those within the jurisdiction of the Federal Energy Regulatory Commission and the Board of Contract Appeals. The Board of Contract Appeals is an independent, separate component within the Office for rendering decisions pertaining to contract disputes and related issues. Jurisdiction of the Office of Hearings and Appeals encompasses complaints filed under the DOE Contractor Employee Pro- tection Program, Proposed Remedial Orders issued by the Economic Regulatory Administration, and Personnel Security Hearing and Review functions. Analyzes and decides appeals requesting review of any determination reached by any other official within the Department under the jurisdiction of the Secretary, including initial determinations under the Freedom of Information Act, the Privacy Act, the payments-equalto-taxes (PETT) provisions of Nuclear Waste Policy Act of 1982, as amended, the special assessment provisions for the Uranium Enrichment Decontamination and Decommissioning Fund under the Energy Policy Act of 1992, the reimbursement of costs of remedial actions at active uranium or thorium processing sites under the Energy Policy Act of 1992, the emergency international oil allocation provisions of the Energy Policy and Conservation Act, and the Standby Mandatory Crude Oil and Product Allocation, Refinery Yield Control and Pricing Programs. Responsible for deciding Applications for Exception from the generally applicable requirements of a rule, regulation, or order of the Department. Develops and implements procedures under the Petroleum Overcharge Distribution and Restitution Act of 1986 for refunding oil overcharge funds obtained pursuant to Departmental consent orders, remedial orders, and court orders to injured parties. Analyzes Petitions for Special Redress seeking "extraordinary relief" apart from, or in addition to, any other remedy provided in the Department's enabling statutes.

\section{Office of Management Operations \\ Vacant, Director \\ HG-10, Room 6G-041, Forrestal \\ (202) $586-6622$}

Responsible for establishing and operating the filing systems and docket facilities in connection with all adjudications pending before the Office of Hearings and Appeals. Also, provides administrative support and general management assistance to other HG offices.

\section{Management Information Division Otto S. Reid, Director HG-12, Room 6G-041, Forrestal (202) $586-6622$}

Establishes and operates a management information system which contains a full history of all filings made in cases under consideration by the Office. Maintains an information retrieval and data system in connection with all adjudications. 


\section{Docket and Publications Division Marcia B. Carlson, Director HG-13, Room 6F-078, Forrestal (202) $586-4924$}

Receives, screens, logs, and controls all documents submitted to the Office in connection with pending cases. Maintains official DOE case history files for all matters in which the Office has rendered a decision. Certifies the record on appeal when a matter is appealed to the courts or to the Federal Energy Regulatory Commission. Operates a Public Reference Room through which the public is afforded access to filing, decisions, and other documents with respect to cases which are either pending or have been decided by the Office. Arranges for the publication and dissemination of all Decisions and Orders of the Office of Hearings and Appeals.

\section{Office of Legal Analysis \\ Thomas O. Mann, Deputy Director \\ HG-20, Room 6G-087, Forrestal \\ (202) 586-2094}

Performs legal research with respect to submissions filed with the Office and recommends the final decision which the Department should issue with respect to Appeals, Applications for Exception, and other proceedings that primarily focus upon legal issues. Develops a full administrative record by receiving documentary evidence, conducting adversarial hearings, and preparing detailed written determinations. Formulates the legal procedures and substantive standards for the various types of adjudicative proceedings within the jurisdiction of the Office of Hearings and Appeals. The legal aspects of the Department's decision must satisfy due process standards and withstand review by the courts. The work of this Office is, therefore, central to the implementation of the Administration's energy policy. Those decisions establish precedent and legal guidance for key divisions of the Department and govern the manner in which these offices exercise their responsibilities and affect all levels of the energy industry. This Office also provides legal support to the Director and to other offices in the Department on matters involving Office of Hearings and Appeals litigation and procedural regulations.

\section{Office of Financial Analysis \\ Richard T. Tedrow, Director HG-30, Room 6G-030, Forrestal (202) 586-8018}

Analyzes submissions and recommends the decisions which the Office should issue with respect to those Appeals, Applications for Exception, Proposed Remedial Orders, refund petitions, and other submissions that involve complex financial issues. Also develops a full administrative record by receiving documentary evidence, conducting hearings, and preparing detailed written determinations. The submission considered by this Office requires analysis of major corporate transactions, the structuring of detailed remedies for regulatory abuses, and the development and implementations of plans which assess the extent of injury and establish mechanisms to make monetary restitution for prior regulatory violations. Activities involved the selection and application of various methods of financial analysis and the use of sophisticated indices to measure the fiscal impact of Departmental programs on a wide variety of business and governmental entities throughout the Nation.

\section{Office of Economic Analysis Thomas L. Wieker, Director HG-40, Room 6F-055, Forrestal (202) $586-2400$}

Analyzes submissions and recommends the decisions that the Office should issue with respect to those Appeals, Applications for Exception, and other requests that primarily focus upon economic issues. In reaching determinations on these applications, the Office develops a full administrative record by receiving documentary evidence, conducting adversarial hearings involving expert econometric testimony, and preparing detailed written determinations. Submissions considered by this Office require economic analysis of the activities of major corporations in order to assess the effects of those activities and to structure specific remedies for regulatory abuses. This Office performs analyses to develop appropriate economic structures for refunding petroleum overcharges to adversely affected parties. The resolution of these issues results in a substantial impact on various sectors of the economy, including refiners, major utilities, industrial and military installations, as well as on Federal, State, and local governmental entities in all regions of the United States. This Office also analyzes the benefit and burden on firms requesting relief from EIA reporting requirements.

\section{Board of Contract Appeals E. Barclay Van Doren, Director HG-50, Room 1006, Webb Building 4040 N. Fairfax Drive \\ Arlington, VA 22203 \\ (703) 235-2700}

The Energy Board of Contract Appeals is an administrative tribunal established pursuant to the Contract Disputes Act of 1978. It independently hears and decides appeals by contractors from contracting officer decisions under rules of procedure published in 10 C.F.R. 1023, Subpart A, and rules implementing the 
Equal Access to Justice Act published in 10C.F.R. 1023, Subpart C. Under authority granted by the Secretary, the Board also performs other quasi-judicial functions as the Energy Financial Assistance Appeals Board (10 C.F.R. 600.26 and 10C.F.R. 1024), the Energy Invention Licensing Appeals Board (10 C.F.R. 781-63), the Energy Patent Compensation Board (10 C.F.R. 780), and the Contract Adjustment Board (10 C.F.R. 1023, Subpart B); decides certain appeals filed by subcontractors of management and operating contractors; and provides hearings officers for environmental, Debt Collection Act, and employee salary offset proceedings. Board decisions are not reviewable by the Department; however, decisions rendered under the Contract Disputes Act may be appealed by either the contractor or the Department directly to the Court of Appeals for the Federal Circuit. The Board also serves as the board of contract appeals for the Nuclear Regulatory Commission.

\section{OFFICE OF PROCUREMENT, ASSESSMENT, AND PROPERTY \\ Grover L. Allen, Director \\ HR-52, Room 4H-065 Forrestal \\ (202) $586-8613$ \\ Office of Policy \\ Luther Jay Tilman, Director \\ HR-521, Room 8H-023 Forrestal \\ (202) 586-8182}

Responds to questions related to DOE contracting rules and regulations.

\section{Office of Clearance and Support \\ Ronald E. Cone, Director \\ HR-522, Room 1E-016, Forrestal \\ (202) $586-9065$}

Provides general information regarding submission of unsolicited proposals to DOE, answers requests for information concerning DOE Requests for Proposals, and serves as focal point for questions related to doing business with DOE.

\section{Office of Headquarters Procurement Operations David G. Newman, Director HR-53, Room 402, 1615 M Street, N.W. (202) 634-4540}

Serves as the central point of contact for Headquarters contracting needs.

\section{Office of Administrative Services}

\section{Reference and Information Management Division \\ Freedom of Information and Privacy Branch Denise B. Diggin, Chief HR-831, Room 1G-051, Forrestal (202) 586-5955}

Handles requests for information under the jurisdiction of the Freedom of Information Act and the Privacy Act.

\section{Printing and Graphics Division Energy Technology Visuals Collection (ETVC) HR-84, Room BH-039, Forrestal (202) $586-9796$}

ETVC, which dates from the 1977 inception of DOE, serves as a central repository for visual aids representing the Department's many research and development activities. The collection, maintained and operated by the Office of Administrative Services, contains high quality photographs of over $600 \mathrm{DOE}$ sponsored projects in such areas as fossil fuels, nuclear fission and fusion, solar energy, conservation, and environmental activities. Images are available as 8 " $x$ $10^{\prime \prime}$ black and white prints, 8 " $\times 10^{\prime \prime}$ color prints, and 35 $\mathrm{mm}$ color slides through the Graphics Branch on Form HQ F 1420.16. Each image requested from the collection is accompanied by a computer-generated data sheet containing caption and background information. An automated cataloging system is used by the ETVC staff to conduct online searches of the data base with respect to program, project, technology, and geographic location. ETVC supports DOE program personnel as well as other Federal, State and local agencies, and the private sector, upon approval, in preparing publications and presentations.

\section{OFFICE OF ARMS CONTROL AND NONPROLIFERATION \\ Victor E. Alessi, Director IS-40, Room 4C-014, Forrestal (202) 586-2102}

Responsible for the development of DOE positions, policies, and plans relating to arms control and nonproliferation and for overseeing DOE's supporting activities. 
238 Office of Arms Control

Anthony F. Czajkowski, Acting Director

IS-40, Room 4C-014, Forrestal

(202) 586-7744

Responsible for developing and coordinating DOE positions, policies, and plans relating to arms control and for overseeing DOE's supporting activities.

\section{Policy and Technical Analysis Division Gail Bradshaw, Director IS-40, Room 4C-014, Forrestal (202) 586-7744}

Responsible for policy and technical analytical support for development, coordination, and representation of DOE positions within the U.S. Government and for international deliberations pertaining to arms control and nonproliferation treaty negotiation, treaty implementation, and compliance determination processes.

\section{Office of Nonproliferation Policy Edward T. Fei, Acting Director IS-40, Room GA-017, Forrestal (202) 586-6175}

Responsible for DOE's implementation of U.S. nonproliferation policy, including support for the work of the International Atomic Energy Agency (IAEA); negotiation of new international agreements for cooperation in the peaceful uses of atomic energy; review and approval of "subsequent arrangements" under the $\mathrm{Nu}$ clear Non-Proliferation Act and Atomic Energy Act; and management of the Reduced Enrichment Research and Test Reactor (RERTR) Program.

\section{Office of Export Control and International Safeguards John M. Rooney, Director IS-40, Room GA-045, Forrestal (202) 586-2112}

Responsible for supporting U.S. nuclear export control systems, supporting international nuclear export control activities, and supporting international safeguards activities by the International Atomic Energy Agency (IAEA).

\section{Export Control Operations Division Trisha Dedik, Director IS-40, Room GA-030, Forrestal (202) $586-8460$}

Responsible for supporting U.S. and international export control activities, including the review of requests to export technology and commodities of nuclear nonproliferation concern. Provides a technology base which supports all U.S. agencies that are involved in nuclear technology denial, including the development of policy, licensing, and enforcement.

\section{International Safeguards Division Kenneth E. Sanders, Director IS-40, Room GA-017, Forrestal (202) $586-8460$}

Responsible for participating for DOE in formulation and implementation of U.S. Government nonproliferation policy concerning the International Atomic Energy Agency (LAEA), international safeguards and physical protection, and nuclear inspection activities. In particular, provides oversight and direction for analyses, strategies, procedures, instrumentation, technology, and training in support of U.S. Government nuclear nonproliferation policy.

\section{Office of Emergency Management John J. Nettles, Acting Director IS-60, Room GE-262, Forrestal (202) 586-9892}

Develups and operates systems to detect and assess developing emergency situations. Ensures an integrated and coordinated Departmental response to all emergencies. Conducts tests and exercises of emergency plans to improve emergency planning and response capabilities. Monitors domestic and international energy systems to evaluate energy market conditions and recommends responses. Conducts appraisals of emergency management programs and capabilities to ensure implementation of emergency plans and procedures. Assists other Federal agencies, State, and local governments, and industry in preparing for and responding to an energy emergency.

\section{OFFICE OF LABORATORY MANAGEMENT \\ Antoinette Grayson Joseph, Acting Director LM-1, Room 3F-077, Forrestal \\ (202) 586-5447}

Assists the Science and Technology Advisor with his responsibilities for the overall vitality of the DOE National Laboratories, both as individual institutions and as a collective intellectual resource for the Nation. Assesses the overall strength and vitality of the multiprogram laboratory system and fosters resolution of system-wide issues and concerns, such as the role of the laboratories and policies governing their use. 


\section{Laboratory Management Division Alan B. Claflin, Director LM-10, Room 3F-077, Forrestal (202) $586-9740$}

Develops and coordinates Departmental policy and monitors its implementation in the following areas: strategic and institutional planning for multiprogram laboratories, laboratory appraisals, work by the laboratories for non-DOE sponsors, laboratory-directed research and development, laboratory technology transfer implementation and education support, and general purpose facilities.

\section{Office of Technology Utilization \\ Roger A. Lewis, Director LM-20, 3H-017, Forrestal \\ (202) $586-5388$}

Develops internal technology transfer and utilization policies that cut across program lines, including budget cross-cuts and training, providing definitive interpretation of these policies, and coordinating them with other Federal agencies. Serves as focal point for developing new models of cooperation and supporting the development of new tools and techniques for commercialization and for measuring the effectiveness of DOE's technology transfer and commercialization activities. Coordinates Departmental technology transfer outreach activities to U.S. industry, academia, and State/local government, and acts as liaison to such groups. Has lead for arranging DOE representation, by personnel and exhibits, at technology transfer conferences, conventions, trade fairs, etc. Prepares outreach publications.

\section{OFFICE OF NUCLEAR ENERGY (NE) Office of the Director Daniel A. Dreyfus, Acting Director NE-1, Room 5A-115, Forrestal (202) $586-2240$}

Formulates and directs the Department's research and development programs associated with the theory and production of Atomic Energy, through nuclear reactor development, both civilian and naval; isotope production and related sales; space nuclear applications; and residual uranium program activities.

\section{Office of Policy and Management \\ George F. Cole, III, Director \\ NE-10, Room 5A-115, Forrestal \\ (202) $586-6630$}

Directs international nuclear safety assistance programs. Formulates and implements international nuclear policy options. Interfaces with other
Departmental elements on intelligence, nonproliferation, and safeguards matters.

\section{International Programs Division Sol Rosen, Director \\ NE-14, Room B-413, Germantown (301) $903-3218$}

Develops and implements international policy options. Coordinates policy development within DOE, other U.S. Government agencies, agencies of foreign governments, and international organizations, as appropriate. Representative international policy areas include: research and development collaboration, nonproliferation, international safety rules and regulations, and foreign nuclear powerplants operational safety.

\section{Reactor and Safety Assistant to Russia/Ukraine Division Sol Rosen, Acting Director NE-15, Room B-413, Germantown (301) 903-3218}

Manages programs to improve cooperation and assistance in nuclear power activities. Serves as the U.S. Co-Chairman of the Joint Coordinating Committee for Commercial Nuclear Reactor Safety with Russia and Ukraine.

\section{Office of Uranium Programs Norton Haberman, Acting Director NE-30, Room A-251A, Germantown (301) 903-4321}

Responsibilities include planning, policy and program development, and direction in the execution of uranium program requirements of the Energy Policy Act of 1992 and for activities attendant to the retained DOE ownership of uranium enrichment facilities, both leased and non-leased, and technologies. Provides policy guidance and oversight of activities that support the United States Enrichment Corporation (USEC) on a reimbursable basis.

\section{Enrichment Oversight and Uranium Revitalization Division Richard E. Dierlam, Acting Director NE-32, Room A-271, Germantown (301) $903-4781$}

Develops, implements, and directs programs to promote the export of domestic uranium, and to encourage State and local utility regulators to consider uranium import dependence in their regulatory decisions. Reports annually to Congress on actions taken with respect to the domestic uranium industry. 


\section{Facility and Technology Management Division \\ Robert M. George, Director \\ NE-33, Room A-285, Germantown \\ (301) 903-5922}

Administers and oversees the lease between DOE and USEC covering cost-reimbursable services and other matters of joint interest.

\section{Office of Civilian Reactor Development \\ Edson C. Brolin, Director NE-40, Room 5A-115, Forrestal (202) $586-2240$}

Responsible for the support of the national energy strategy by developing and implementing programs to ensure that nuclear energy remains a safe, economically competitive, and environmentally acceptable option that continues to contribute to national energy stability, security, and strength.

\section{Actinide Recycle Division Jerry D.Griffith, Director NE-42, Room A-411, Germantown (301) 903-4414}

Develops and recommends goals, policies, and associated strategies that provide technically sound and economic approach for disposal of spent fuel actinides and weapons plutonium in fission reactors.

\section{Advanced Neutron Source Division Ray A. Hunter, Acting Director NE-43, Room F-424, Germantown (301) $903-2915$}

Provides technical and program guidance for the research and development, design, construction, and operation of the ANS consistent with DOE policies and practices, with particular emphasis on environmental acceptability, safety, safeguards and security, and operational efficiency to meet DOE mission requirements.

\section{Facilities Division Ray A. Hunter, Director NE-44, Room F-424, Germantown (301) $903-2915$}

Provides technical and program guidance for the operation and initial decommissioning of NE test facilities in a safe, cost-effective, reliable, and environmentally acceptable way. Provides technical and program guidance for the design, construction, operation, and initial decommissioning of Energy Research reactors and associated facilities.

\section{Advanced Light Water Reactors Division David J. McGoff, Director NE-45, Room A-439A, Germantown (301) $903-5447$}

Directs and implements Light Water Reactor safety and technology programs, including the light water reactor extended plant lifetime technology program, to address serious regulatory, performance, and perception obstacles to nuclear deployment. Maintains an up-to-date status of the financial conditions of nuclear utilities, including plant construction and/or cancellation information.

\section{Isotope Production and Distribution Division \\ Donald E. Erb, Director \\ NE-46, Room F-402, Germantown \\ (301) $903-5338$}

Directs all isotope production and distribution activities within DOE. This entails coordination with the Offices of DP and ER, the Operations Offices, other appropriate departmental elements to establish production requirements and schedules and determine long-range production capabilities.

\section{Office of Space and Defense Power Systems \\ Alan R. Newhouse, Director \\ NE-50, Room A-420, Germantown (301) 903-4306}

Responsible for fulfilling DOE's charter under the Atomic Energy Act to support other Federal agencies in the design, development, production, and testing of reactor and isotope power systems for space and special purpose terrestrial applications and by maintaining a base technology program that advances new technologies that may be used in future system development.

\section{Space Reactor Power Systems Division Wade P. Carroll, Director NE-52, Room E-430, Germantown (301) $903-3321$}

Provides technical and program guidance for the design, development, testing, and construction of nuclear power and propulsion reactors for civilian or defense applications, including safety. Integrates other reactor development activities in support of co- 
operative projects with other agencies for the development of nuclear systems.

\section{Radioisotope Power Systems Division Robert G. Lange, Director NE-53, Room E-416, Germantown (301) $903-4362$}

Provides overall program management and integration of agency radioisotope power systems; and technical and program guidance for the development, testing, and production of radioisotope power systems in support of civilian and military space and terrestrial missions.

\section{Office of Naval Reactors Bruce DeMars, Director NE-60, Room 3N06, National Center 2 (703) 603-7321}

Ke:ponsible for conducting requirements under Section 309(a) of the DOE Organization Act which assigns civilian power reactor programs and all DOE naval nuclear propulsion functions.

\section{OFFICE OF PUBLIC AND CONSUMER AFFAIRS (PA) \\ Michael G. Gauldin, Director \\ PA-1, Room 7A-145, Forrestal \\ (202) $586-4940$}

Responsible for managing and overseeing the overall press services, public affairs, and public information activities of the Department. Provides policy advice and support when interacting with the news media.

Audiovisuals and Exhibits

(202) $586-4670$

Consumer Affairs/Public Liaison

(202) 586-5373

DOE This Month

(202) 586-2050

Press Office

(202) $586-5806$

Publications/Public Inquiries

(202) 586-5575

Speakers' Bureau

(202) $586-3650$

\section{ASSISTANT SECRETARY FOR POLICY, PLANNING AND PROGRAM EVALUATION (PO) Susan F. Tierney, Assistant Secretary PO-1, Room 7C-034, Forrestal (202) $586-4640$}

Responsible for developing and directing domestic and international energy policy, including the international component of overall energy policy, and for coordinating the Department's energy emergency preparedness planning and emergency operations (except nuclear incidents/accidents) and the encouragement of free trade in energy resources, services, equipment, and technology.

\section{Office of the Deputy Assistant Secretary for Policy Planning and Implementation Vacant, Deputy Assistant Secretary Secretary PO-5, Room 7C-034, Forrestal (202) $586-4640$}

Responsible for directing and coordinating the activities of the following three subject-matter policy offices: the Office of Oil and Natural Gas Policy; the Office of Electricity, Coal, Nuclear and Renewable Policy; and the Office of Energy Demand Policy. This function synthesizes the various policy positions and ensures that policy development activities are effectively integrated.

\section{Office of Energy Demand Policy Carmen Difiglio, Director PO-50, Room 7H-021, Forrestal (202) $586-4444$}

Responsible for (1) planning, directing, and coordinating the Department's process to identify energy demand policy priorities and to develop strategies for integrating energy demand policies; (2) conducting macroeconomic analysis of cross-cutting energy demand issues; (3) conducting policy and program analysis and evaluation of our energy efficiency issues; (4) conducting policy analysis in areas that cut across consumption of conventional and alternative fuels; and (5) designing and implementing special projects, as assigned. 


\section{Office of Electricity and Generating \\ Fuels Policy \\ David H. Meyer, Acting Director \\ PO-51, Room 7H-075, Forrestal \\ (202) $586-5727$}

Responsible for analyses and recommendations on policy issues associated with the economic, technical, environmental, regulatory, and institutional factors that affect the supply and demand of electric energy, coal, nuclear, and renewable resources. Major areas of concentration include analysis of electric power, coal and nuclear resource markets, incentives designed to stimulate production and availability for more efficient use of resources and enhance U.S. energy security. It is the lead DOE Office for the development of national policy in the area of electric power, coal, nuclear, and renewable resource markets.

\section{Office of Oil and Natural Gas Policy Leonard L. Coburn, Acting Director PO-52, Room 7H-063, Forrestal (202) 586-5667}

Responsible for analyses and recommendations on policy issues associated with domestic and international oil and natural gas markets. Major areas of concentration include economic analyses of the behavior of the Organization of Petroleum Exporting Countries, market responses to changing oil prices, incentives designed to stimulate increased oil production or greater oil conservation, and Government policies designed to deregulate domestic oil and natural gas markets and enhance U.S. energy security. Provides broad-based technical support in areas of oil industry structure, production and supply modeling, and economic analysis to other policy, planning, and analysis offices.

\section{Office of the Deputy Assistant Secretary for Economic and Environmental Policy Abraham E. Haspel, Deputy Assistant Secretary PO-6, Room 7C-034, Forrestal (202) $586-5316$}

Responsible for directing and coordinating the activities of the Office of Planning, the Office of Program Review and Analysis, and the Office of Technology Analysis. This function synthesizes the various outyear program budget positions with the Department's planning strategies and technology outlook.

\section{Office of Environmental Analysis Edward R. Williams, Director PO-60, Room 4G-036 Forrestal (202) 586-2061}

Responsible for development, implementing, and managing a Departmentwide plan that will include specific program goals and related funding requirements.

\section{Office of Economic Analysis and Competition \\ Howard K. Gruenspecht, Director PO-61, Room 7H-034 Forrestal \\ (202) $586-4767$}

Responsible for directing the implementation of the National Energy Strategy, providing analysis of the Department's program budgets, and reviewing proposed program budget priorities for conformance with established and revised goals and objectives for short- and long-range energy policy.

\section{Office of Program Review and Analysis \\ Robert C. Marlay, Director \\ PO-62, Room 7H-085, Forrestal \\ (202) $586-3900$}

Functions as the lead office for the analysis and development of national policy in the area of energy technology; prepares the energy technology portion of the National Energy Policy Plan; analyzes, evaluates, and recommends alternative plans and guidance for DOE energy technology programs to meet national energy objectives; conducts policy and program analysis and evaluation; and conducts analysis of economic, technical, environmental, and institutional factors that affect the use of energy technology to enhance DOE's ability to deal effectively with energy issues. Provides broad-based technical support in areas of energy industry structures, production, and supply modeling and economic analysis to other DOE Offices.

\section{Office of Strategic Planning John R. Sullivan, Acting Director PO-63, Room 7B-044, Forrestal (202) $586-5390$}

Provide analyses and options developments with respect to significant environmental issues that affect national energy supply, demand, and prices. 


\section{Office of the Deputy Assistant \\ Secretary for International Affairs \\ Richard H. Williamson, Deputy Assistant \\ Secretary \\ PO-7, Room 7C-034, Forrestal \\ (202) $586-5493$}

Oversees the development and conducting of international energy policy consistent with U.S. foreign policy objectives; the promotion of a balanced and mixed energy resource system through the execution of an effective international energy research and development collaboration policy; and the strengthening of the international nuclear nonproliferation regime, which continues to promote the peaceful uses of nuclear energy.

\section{Office of International Research and Development Policy \\ Harold Jaffe, Director \\ PO-70, Room 1E-218, Forrestal \\ (202) $586-6770$}

Develops and directs a program for the systematic review of international research and development technology cooperation activities in conjunction with existing programs involving Government-to-Government and industry-to-Government arrangements supporting DOE and U.S. program interests.

\section{Office of International Energy Analysis John R. Broadman, Director PO-71, Room 7G-09n, Forrestal (202) $586-5915$}

Monitors and analyzes world energy market developments and the international political, economic, and strategic factors that influence this development; provides policy recommendations on a wide range of international energy security issues; manages U.S./DOE participation in international organizations and with consuming and producing nations; and ensures the integration of the factors that arise into overall international energy policy and analyses.

\section{International Energy Organizations and Policy Development Division Robert S. Price, Jr., Director PO-711, Room 7G-046, Forrestal (202) $586-6383$}

Develops objectives, generic policy positions, specific Folicies with respect to individual foreign countries, and prepares briefing papers for all USG energy-related bilateral and multilateral Ministerial discussions.

\section{Energy Assessments Division David L. Pumphrey, Director PO-712, Room 7G-076, Forrestal (202) 586-6832}

Develops strategic assessments on critical international energy issues to include world oil market conditions, petroleum stocks, natural gas security, electricity policy and energy/environmental interactions, and energy trade.

\section{OFFICE OF CIVILIAN RADIOACTIVE WASTE MANAGEMENT (RW) Daniel A. Dreyfus, Director RW-1, Room 5A-085, Forrestal (202) 586-6842 \\ Public Information System (800) 225-6972}

Responsible for the implementation of the Nuclear Waste Policy Act (NWPA) P. L. 97-425, as amended, to provide for the characterization and determination of suitability for the Yucca Mountain, Nevada, site for the development of a repository for the disposal of high-level radioactive waste and spent nuclear fuel; the development of interim storage capabilities prior to the availability of a repository for permanent disposal; and the development of transport capability for the waste management system in a manner that fully protects the public health and safety and is in accordance with the NWPA of 1982.

\section{Office of Quality Assurance Donald G. Horton, Director RW-3, 101 Convention Center Drive Las Vegas, NV 89109 (702) $794-7675$}

Responsible for the development, management, coordination, integration, and overview of the quality assurance program. Additionally, responsible for conducting audits at Headquarters, site locations, and at contractor facilities associated with the program; performing quality surveillance of Federal and contractor activities; and identifying deficiencies, preparing corrective action reports, and verifying implementation of corrective action. 


\section{Office of Strategic Planning and International Programs Jerome D. Saltzman, Acting Director RW-4, Room 5A-051, Forrestal (202) 586-1252}

Primary responsibility is for overall development of strategic and contingency plans. Aloo manages the international program and develops and prepares strategy for risk management and communication. Interfaces with the National Academy of Sciences on policy and technical issues.

\section{Office of External Relations Jerome D. Saltzman, Director RW-5, Room 5A-051, Forrestal (202) 586-2277}

Primary responsibility for managing the program's institutional relations, including those with the key affected organizations external to DOE. Responsible for the development and implementation of a national education institution program and coordinates relations with affected governments, interested parties, the general public, and appropriate educational entities; coordinates international conferences, manages congressional relations and public information; ensures the integration of institutional with the technical activities of all program components in the Office of Civilian Radioactive Waste Management; provides policy and program direction for institutional relations, financial assistance, and socioeconomic studies; develops Office communications program, its policy and requirements; and provides guidance and compliance oversight.

\section{Office of Program and Resources Management Samuel Rousso, Associate Director RW-10, Room GF-253, Forrestal (202) 586-9116}

Responsible within RW for the development, implementation, and maintenance of a total quality management program; information resources and records management; development of the total system life cycle cost estimates; and the project decision schedule and program cost and schedule baseline. Additionally, responsible for the proper management and administration of the Nuclear Waste Fund and Civilian
R\&D accounts; manpower and organization planning and personnel management; and preparation and execution of office budgets.

\section{Office of Geologic Disposal \\ Robert M. Nelson, Jr., Acting Associate \\ Director \\ RW-20, 101 Centerville Drive \\ Las Vegas, NV 89109 \\ (702.) 794-7920}

\author{
Yucca Mountain Site Characterization \\ Project Office \\ 101 Convention Center Drive \\ Las Vegas, NV 89109 \\ (702) 794-7920
}

Responsible for developing and implementing strategies related to the evaluation of the suitability of the Yucca Mountain site, for preparation of an environmental impact statement in compliance with the NEPA process, and for pre-licensing interactions with the NRC leading to preparation and submittal of a license application, should the site be found suitable; developing, evaluating, and documenting site suitability assessment criteria and related assessment methods; designing, developing, siting, constructing, and operating a test-and-evaluation facility; developing and implementing a waste package implementation strategy; and developing the physical subsystem (e.g., natural and engineered barriers) required to dispose of the high-level waste. Responsible for planning, managing, and evaluating the development, siting, design, construction, operation and decommissioning of a geologic repository.

\section{7 office of Systems and Compliance Dwight E. Shelor, Associate Director RW-30, Room TF-031, Forrestal (202) $586-6046$}

Responsible for planning, managing, and overseeing the development, integration, and evaluation of the civilian radioactive waste management system; develops and controls all systems engineering policy and requirements and coordinates the Department's interactions with the Nuclear Regulatory Commission; establishes environmental compliance requirements; develops alternate licensing strategies; and develops a Program Management System. 
288 Office of Storage and Transportation

Ronald A. Milner, Associate Director RW-40, Room 7F-059, Forrestal

(202) 586-9694

Responsible for planning, managing, and evaluating the development, siting, design, construction, operation, and decommissioning of a Monitored Retrievable Storage (MRS) facility for the interim storage of spent nuclear fuel. Develops policy and implements procedures for site selection. Additionally, manages utility contracts and serves as the primary technical interface with the nuclear utilities. Manages the development and operation of a comprehensive system to transport spent nuclear fuel and high-level radioactive waste from the reactor sites to the MRS and the repository. Conducts analyses of the adequacy of the waste management fees paid by owners/generators of spent nuclear fuel and high-level waste to cover program costs and establish fees for waste forms not covered by existing fee structure.

\section{Office of Contract Business Management Samuel Rousso, Director RW-50, Room GF-253, Forrestal (202) 586-9116}

Responsible for managing the procurement/business activities of the Management and Operating (M\&O) contract; developing a Contract Management Plan; overseeing and administering the award fee process for the M\&O contractor; monitoring performance; and analyzing $\mathrm{M} \& \mathrm{O}$ cost and schedule information. Also responsible for managing the procurement/business activities of RW and providing centralized contract management support.

\section{Federal Energy Regulatory Commission (FERC)}

\author{
290 Congressional Affairs and State \\ Liaison \\ Office of External Affairs \\ Don Chamblee, Director \\ EA-20, 825 North Capitol Street, $N$ I.., \\ Room 9204 \\ Washington, DC 20002 \\ (202) 208-0870
}

Serves as liaison with Congress, including the committees of Congress having oversight authority on matters affecting the Federal Energy Regulatory Commission. This Division coordinates presentation of Commission testimony, information, and views pertaining to legislative issues and proposals. This Division also serves as liaison to State Government offices, including the governors and State legislators.

\section{Press Services Office of External Affairs Ron Harris, Director and Press Secretary EA-10, 825 North Capitol Street, N.E., Room 9200 Washington, DC 20002 (202) 208-0680}

Meets the information needs of the news media on the full range of energy regulatory subjects and proceedings within the Commission's jurisdiction. There are information specialists in the fields of natural gas, electricity, hydroelectric projects, and oil pipelines in this Division.

\section{Public and Intergovernmental Affairs Office of External Affairs \\ Vacant, Director EA-30, 825 North Capitol Street, N.E., Room 9200 Washington, DC 20002 (202) 208-1088}

Responds to inquiries from the public, industry, interest groups, and Federal, State and local governments about Commission regulatory activities, actions, and procedures. This division also serves as a communications link with the National Association of Regulatory Utility Commissioners and their member State commissions. This Division helps identify sources of energy-related information and data, availability of FERC publications, and other matters of broad general interest. The Division develops informational and educational materials on energy regulatory subjects, coordinates the scheduling of speaking engagements by FERC officials, and processes and responds to Freedom of Information and Privacy Acts or other written, oral, and telephonic requests for information. 


\section{Department of Energy Laboratories, Field Facilities, and Power Administrations}

Following are alphabetically listings of DOE Operations Offices, as well as DOE facilities that are not under direct supervision by a university or DOE Operations Office. Facilities that are under such supervision are listed with an asterisk (*) under the appropriate office. The list does not include the various area offices of DOE or its affiliated installations.

\section{DOE Laboratories and Field Facilities}

\section{ALBUQUERQUE OPERATIONS OFFICE U.S. Department of Energy \\ Ben McCarty, Public Affairs Officer P.O. Box 5400 \\ Albuquerque, NM 87185-5400 \\ (505) 845-5596}

Provides DOE field level planning, coordination, and direction of the nuclear weapons research, development, and production programs in an environmentally sound manner. Responsible for the operation and direction of the nuclear weapons production complex. Operates the DOE transportation safeguards system. Provides field level planning, coordination, and direction of non-iw eapons work assigned, such as nuclear, solar, geothermal, wind energy projects, waste management, and transportation research. Manages technology transfer programs between laboratories and industry, and educational initiatives in the State of New Mexico to improve math and science skills.

\footnotetext{
294 Los Alamos National Laboratory University of California

John Webster

Public Information Officer

Mail Stop A-177

P.O. Box 1663

Los Alamos, NM 87545

(505) 667-7000
}

Established in 1943 to develop the world's first nuclear weapons, the primary mission is the application of science and technology to significant problems that impact national security in its broadest sense, including maintenance of a strong defense, economic competitiveness, educational excellence, environmental restoration, and energy independence.

\section{Sandia National Laboratories Rod Geer Public Relations Department 7161 P. O. Box 5800 \\ Albuquerque, NM 87185 \\ (505) 844-6601 \\ FAX (505) 844-6367}

Established in 1949 to assist in developing a national nuclear deterrent, Sandia has major laboratories in New Mexico and California (Livermore). It operates test ranges near Tonopah, Nevada, and on the island of Kauai, Hawaii. With more than 8,000 employees, Sandia operates facilities for manufacturing process development, environmental testing, radiation research, combustion research, computing, and microelectronics research and production. Over Sandia's history, its missions have expanded from an original focus on nuclear weapons R\&D to work on other advanced military technologies, energy programs, arms verification and control technology, and applied research in numerous scientific fields, including an extensive program in materials research. In addition to developing and engineering nuclear weapon components, Sandia assesses, maintains, and upgrades the existing nuclear weapon stockpile and explores advanced weapon concepts. Sandia has the largest arms-control verification technology program in the country. It is the DOE center for pulsed-power research. Sandia also is working to strengthen the nation's economic security by transferring the commercially valuable technologies developed at the labs to U.S. industry. 


\section{BARTLESVILLE PROJECT OFFICE \\ U.S. Department of Energy \\ Herbert A. Tiedemann \\ Technology Transfer \\ P. O. Box 1398 \\ Bartlesville, OK 74005 \\ (918) 337-4293}

FAX (918) 337-4418

Administers and monitors the DOE Fossil Oil Energy Research program, with emphasis on research related to petroleum extraction, processing, and utilization.

\section{CHICAGO OPERATIONS OFFICE}

U.S. Department of Energy

Gary L. Pitchford

Director, Office of Communications

9800 South Cass Avenue

Argonne, IL 60439

(708) 252-2013

An offspring of the Manhattan Engineer District and established as one of the Atomic Energy Commission's first field offices in 1947, the Office is responsible for integrated management of major Government-owned, contractor-operated laboratories and facilities (Argonne National Laboratory, Brookhaven National Laboratory, Fermi National Accelerator Laboratory, Princeton Plasma Physics Laboratory, and Ames Laboratory), as well as two Government-owned and operated laboratories (Environmental Measurements Laboratory and New Brunswick Laboratory). Program and project assignments include high energy physics, environmental restoration and waste management, nuclear physics, basic energy sciences, advanced reactor safety, magnetic fusion energy, solar and alternate energy, and an assortment of research and development initiatives in various energy technologies.

\section{Ames Laboratory}

Steve Karsjen, Manager

Office of Public Affairs and Information

201 Spedding

Iowa State University

Ames, IA 50011

(515) 294-1856

FAX (515) 294-3226

Established in 1947 as a result of the Manhattan Project. The primary mission is to conduct basic research in materials and chemical sciences, chemistry, physics, engineering, metallurgy, mathematics, and related research in materials reliability and nondestructive evaluation.

\section{Argonne National Laboratory \\ Harry Conner \\ Director, Office of Public Affairs \\ 9700 South Cass Avenue \\ Argonne, IL 60439 \\ (312) $972-55 \& 11$}

Established in 1947, conducts applied research and engineering development in nuclear fission and other energy technologies and scientific research in basic physical and life sciences. Develops and operates research facilities for members of the scientific community, maintains close interaction with personnel in universities and industry, and aids in the education of scientists and engineers.

\section{Brookhaven National Laboratory Anne Baittinger, Public Affairs Manager Upton, NY 11973 \\ (516) 282-2123}

Established in 1947, conducts basic and applied research in technology base areas, supports research facilities, and establishes new directions for research. Major disciplinary strengths are high energy, nuclear and solid state physics, chemistry, environmental and life sciences, and selected energy technologies.

\section{Fermi National Accelerator Laboratory Barbara Lack Public Information Office \\ P. O. Box 500 \\ Batavia, IL 60510 \\ (808)840-3351}

FTS (708) 370-3351

Established in 1967 to explore the field of elementary particle physics so that the understanding of the basic structure of matter may be broadened. The lab's principal scientific tool is the Tevatron--the world's first superconducting accelerator and currently the highest energy accelerator in the world. Protons and antiprotons travel at nearly the speed of light in the Tevatron's tunnel, which is 6.3 kilometers in circumference.

\section{National Accelerator Laboratory Barbara Lach Public Information Office P.O. Box 500 Batavia, IL 60510 (312) 840-3351}

Established in 1967 to explore the field of elementary particle physics so that the understanding of the basic structure of matter may be broadened. A related mis- 
sion is the improvement of accelerator design that has resulted in numerous technological spin-offs: the development of various applications other than magnets for superconductivity; fast electronics and particle detector technology; and special computers and computer programs.

\section{Princeton Plasma Physics Laboratory (PPPL) Anthony R. DeMeo, Jr., Director Information and Administrative Services P. O. Box 451 Princeton, N] 08543 \\ (609) 243-2755}

PPPL performs research aimed at the development of magnetic fusion energy as an inexhaustible, safe, and environmentally acceptable means of generating electricity for the long-term. The Laboratory operates two major magnetic fusion devices: the Tokamak Fusion Test Reactor (TFTR) and the Princeton Beta Experiment-Modified (PBX-M). PPPL and representatives of other U.S. fusion laboratories, universities, and private industry are collaborating on the design of the Compact Ignition Tokamak (CIT), which is currently planned for construction at PPPL during the mid1990 's. PPPL physicists also participate in a worldwide collaboration to design the International Thermonuclear Experimental Reactor (ITER). PPPL scientists are applying knowledge gained in fusion research to a number of other areas, including the development and application of soft $x$-ray lasers, the study of spacecraft glow and erosion, and the plasma etching of electronic circuitry on semiconductor chips.

\section{ENVIRONMENTAL MEASUREMENTS LABORATORY \\ U.S. Department of Energy \\ Philip W. Krey, Acting Director \\ 376 Hudson Street \\ New York, NY 10014-3621 \\ (212) 620-3616}

Founded in 1947, conducts experimental and theoretical research concerning radioactive and other energyrelated pollutants in the environment to address important scientific questions related to human health and to environmental impact. Through its multidisciplinary stafi, provides the DOE and other Federal agencies with the in-house capability needed to respond effectively and efficiently to current environmental and related national security issues. The research on nuclear and non-nuclear pollutants is performed through studies of the distribution, composi- tion, and transport of the pollutants from the atmosphere to soil, plants, subsurface aquifers, animals, and humans. Conducts a variety of radio-analytical quality assurance programs ranging from "in-house" to intra- and inter-agency cooperative programs to international intercomparisons.

\section{GRAND JUNCTION PROJECTS OFFICE \\ Michael K. Tucker, Manager \\ P. O. Box 2567 \\ Grand Junction, CO 81502 \\ (303) 248-6000}

The primary mission of the Grand Junction Projects Office (GJPO) is to apply its project management, engineering, and geoscience capabilities to support national programs in environmental restoration, geoscience, and energy. Activities include: the Grand Junction Uranium Mill Tailings Remedial Action (UMTRA) vicinity properties project; the Monticello, Utah, mill site and vicinity properties project; the CERCLA Superfund uranium mill tailings remedial action project; the remediation of DOE's Grand Junction Projects Office; and the DOE-wide Long-Term Surveillance and Maintenance Program. GJPO, which first became involved with environmental restoration in 1973 with the Grand Junction Remedial Action Program (GJRAP), is also involved with environmental restoration of other DOE sites as requested.

\section{IDAHO FIELD OFFICE}

U.S. Department of Energy
Dennis S. Hurtt, Director
Office of External Affairs
785 DOE Place
Idaho Falls, ID 83401
(208) 526-8101

Established in 1949, supports the engineering and operations efforts of the Department of Energy and other Federal agencies in nuclear safety research, reactor development, reactor operations and training, defense-related materials production, waste management and technology development, and energy technology and conservation programs. Promotes industry collaboration in science, technology, and research to enhance U.S. industrial competitiveness. The Field Office administers the Idaho National Engineering Laboratory and manages a field location in West Valley, New York, for the high-level radioactive waste demonstration project at a former commercial nuclear facility. 


\author{
307 LARAMIE PROJECT OFFICE \\ U.S. Department of Energy \\ J. Keith Westhusing, Branch Chief \\ Liquid Fuels Technology Branch \\ Fuels Resources Management Division, \\ METC \\ P. O. Box 1189 \\ Laramie, WX 82070 \\ (307) $721-7200$
}

The lead laboratory under the Morgantown Energy Technology Center primarily responsible for oil shale and tar sands and coal co-products (mild gasification). Performs the interface with the research work being done by the Western Research Institute and by the University of Wyoming. The Office is particularly involved with Lawrence Livermore National Laboratory in its design and operation of the Recycle Solids Oil Shale Retort. Also oversees various coal co-products contracts enhancing methods for providing value-added products from coal. Additional liaison functions are performed with State and Federal entities in the western region.

\section{MORGANTOWN ENERGY TECHNOLOGY CENTER (METC) \\ U.S. Department of Energy \\ William F. Lawson, Director \\ P.O. Box 880 \\ Morgantown, WV 27507-0880 \\ (304) 291-4309 \\ FAX (304) 291-4292}

The Morgantown Energy Technology Center (METC) conducts and manages research and development to enhance the use of U.S. fossil energy resources. Activities at METC focus on developing technologies to increase coal use in an environmentally acceptable manner, to extend the reserve base of natural gas, and to provide economically and environmentally improved techniques for extracting energy from oil shales and tar sands. The goal of these activities is to expand the technology base for fossil energy production, conversion, and use. In addition to on-site research and development, other METC projects are executed through contracts with industry and academia. The Center is located in Morgantown, West Virginia, on a 132-acre site and includes engineering research facilities and extensive laboratory support facilities. The Center is concerned with the future of science and is encouraging students to select scientific and engineering fields as careers. Many resources at the Center are available to assist in student educational activities.

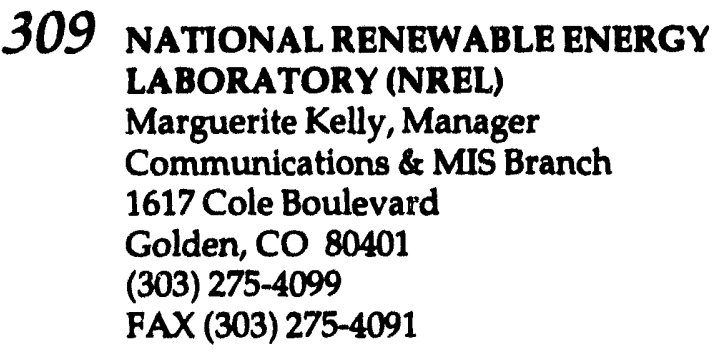

Formerly known as the Solar Energy Research Institute (SERJ), NREL focuses on energy efficiency and renewable energy technology development in the four major energy use sectors-buildings, industry, transportation, and utilities--in support of DOE's Assistant Secretary for Conservation and Renewable Energy. As the principal laboratory for basic and applied research and development in the solar energy conversion technologies, NREL conducts exploratory studies, experimentation and testing in its own facilities, and supports contract research and development with industries and universities throughout the country.

\section{NAVAL PETROLEUM AND OIL SHALE RESERVES IN COLORADO, UTAH, AND WYOMING, NOSR-1, NOSR-2, NOSR-3 \\ U.S. Department of Energy \\ C. Ray Williams, Director \\ 907 N. Poplar Street, Suite 150 \\ Casper, WY 82601 \\ (307) 261-5817 \\ FAX: (307) 261-5817}

Founded between 1912 and 1924 and created to provide an emergency source of liquid fuels for the U.S. Armed Forces. Congress mandated production of the Naval Petroleum Reserves at the Maximum Efficient Rate with the Naval Petroleum Reserves Production Act of 1976.

\section{NAVAL PETROLEUM RESERVES IN CALIFORNIA \\ U.S. Department of Energy \\ Danny A. Hogan, Director \\ P. O. Box 11 \\ Tupman, CA 93276 \\ (805) 763-6011 \\ FAX (805) 763-6699}

Founded between 1912 and 1924 and made a permanent reservation for future naval fuel and oil supplies. Congress mandated the Reserves through the Naval Petroleum Reserves Production Act. 


\section{NEVADA FIELD OFFICE \\ U.S. Department of Energy \\ Office of External Affairs \\ Chris L. West, Director \\ P.O. Box 98518 \\ Las Vegas, NV 89193-8518 \\ (702) 295-3521}

Established by the Atomic Energy Commission in 1962 and based in Las Vegas, the Office manages operations and programs at the Nevada Test Site (NTS). The 1,350-square-mile NTS is a high-security installation for conducting the Nation's underground nuclear weapons testing program. The Office also manages a major defense low-level radioactive waste disposal site; radiological emergency response programs; facilities in the Pacific as part of the Nation's nuclear testing readiness program; construction and operational activities supporting DOE's Yucca Mountain Project and U.S. Department of Defense projects; and a Liquefied Gaseous Fuels Spill Test Facility.

\section{OAK RIDGE NATIONAL LABORATORY \\ L. Darryl Armstrong \\ Manager of Public Affairs \\ (Martin Marietta Energy Systems) \\ P. O. Box 2008 \\ Oak Ridge, TN 37831-6266 \\ (615) $574-4160$ \\ FAX (615) 574-0595}

Performs research supported by DOE on a broad range of energy-related problems and provides technical information and assistance on energy research for State and local governments and the private sector. Areas of research include waste management, fossil, nuclear, fusion, conservation, and environment. Reports on technology applications are available.

\section{OAK RIDGE OPERATIONS OFFICE}

U.S. Department of Energy

James T. Alexander

Assistant to Manager for Public

Information, $\mathrm{M}-4$

P. O. Box 2001

Oak Ridge, TN 37830-8502

(615) 576-0885

Administers the Oak Ridge National Laboratory, the Oak Ridge Associated Universities, the Strategic Petroleum Reserve, the Oak Ridge and the Paducah Gaseous Diffusion Plants, and the Y-12 Production Facility, Feed Materials Production Center, and Wel- don Spring Site Remedial Action Project. Major programs and projects include (1) direction of R\&D programs related to nuclear and other energy sources, (2) production and management of uranium enrichment expansion, (3) direction of biomedical and environmental research, (4) production of nuclear weapons components, and (5) oversight of DOE's Formerly Utilized Sites Remedial Action Project.

\section{Portsmouth Site Office \\ U.S. Department of Energy \\ Gene Gillespie, Manager \\ P. O. Box 700 \\ Piketon, $\mathrm{OH} 45661$ \\ (614) $897-5010$}

Responsible for the technical administration of the contract for the management, operation, and maintenance of the Department of Energy's uranium enrichment production plant at Portsmouth, Ohio. Responsibilities include monitoring day-to-day production operations to assure that contractor-executed functions are carried out in a manner that achieves a quality product and that operations are conducted in a manner that protects personnel, the general public, and the environment.

\section{PITTSBURGH ENERGY TECHNOLOGY CENTER \\ U.S. Department of Energy \\ Sun W. Chun, Director \\ Kay Downey, Technology Transfer Officer \\ P. O. Box 10940 \\ Pittsburgh, PA 15236-0940 \\ (412) 892-6029}

Responsible for technical and administrative management of certain lead mission research and development programs within the Office of Fossil Energy. The Center's program responsibilities are clean coal technology, coal preparation, advanced combustion technology, alternative fuels utilization, flue gas cleanup, coal liquefaction, magnetohydrodynamics, advariced research and technology development in direct utilization and liquefaction, solids transport, university coal research, peat resources, and anthracite coal. Has established a National Coal Technology Data Base where users may have access to Government coal research. Facilities and expertise are available to industry and other research organizations through Cooperative Research and Development Agreements (CRADAs). 


\section{PITTSBURGH NAVAL REACTORS OFPICE}

U.S. Department of Energy

C. K. Gaddis, Manager

P. O. Box 109

West Mifflin, PA $15122-0109$

(412) 476-7200

Oversees the Bettis Atomic Power Laboratory in West Mifflin, Pennsylvania, and the Naval Reactors Facility near Idaho Falls, Idaho. The Bettis Atomic Power Laboratory and the Naval Reactors Facility perform research and development of naval nuclear propulsion plants and operate associated prototype plants.

\section{Westinghouse Electric Corporation Bettis Atomic Power Laboratory Dr. D. R. Connors, Manager Operations Training \\ P. O. Box 79 \\ West Mifflin, PA 15122-0079 \\ (412) 476-6843}

Established in 1949, it is devoted exclusively to the Naval Nuclear Propulsion Program and includes two sites. Bettis, the principal site, performs research and development of naval nuclear propulsion plants and the Naval Reactors Facility operates prototype naval reactor plants and a facility for examining expended naval reactor cores.

\section{RICHLAND FIELD OFFICE \\ U.S. Department of Energy \\ Mike Talbot, Acting Director \\ Office of Communications \\ P.O. Box 550 \\ Richland, WA 99352 \\ (509) 376-7501}

This Office manages the 560-square-mile Hanford Site that employs over 16,000 people. Hanford was established in 1943 as part of the Manhattan Project to make plutonium for nuclear weapons. It is also the site of the Pacific Northwest Laboratory. The plutonium mission has ended at Hanford and the current mission is the environmental restoration of the site. Nuclear and hazardous waste management, interim storage and ultimate disposal of high level nuclear waste, and environmental management are important programs.

320 Battelle Pacific Northwest Laboratory

Gary Petersen

Public Relations Manager

P. O. Box 999

Richland, WA 99352

(509) 375-2924
Battelle Memorial Institute operates the U.S. Department of Energy's Pacific Northwest Laboratory (PLN). PNL's mission is two-fold. As one of the Government's multiprogram national laboratories, it performs basic and applied research for DOE, other Government agencies, and industry. As the technical center for Hanford, the Laboratory provides research expertise and program support for DOE and its contractors. More than 1,000 research projects are conducted annually in support of DOE missions in energy development, national defense, and international competitiveness. PNL actively pursues transfer of Federally funded technologies to industry and academic support through educational enrichment programs and collective research with universities. Headquartered in a private research complex in north Richland, Battelle operates extensive PNL facilities on the Hanford Site. Battelle also conducts a variety of aquatic studies at a mainline research laboratory at Sequim Bay on the Olympic Peninsula and operates a 188-acre conference and study center in north Seattle.

\section{Hanford Environmental Health Foundation Carol Bonadie Public Relations P. O. Box $100 \mathrm{HI}-52$ \\ Richland, WA 99352 \\ (509) 376-6923}

Provides personnel health services in the fields of occupational medicine, behavioral sciences, and environmental health services to DOE and its Hanford contractors. It also conducts occupational and epidemiological research for $D O E$.

\section{Kaiser Engineers Hanford Company}

R. D. Folker

Vice President of Administration

P. O. Box 888

Richland, WA 99352

(509) 376-6967

Performs the architectural-engineering construction for the Department of Energy Hanford Site.

\section{Westinghouse Hanford Company John Burk \\ Director, Communications \\ P. O. Box 1970, B3-25 \\ Richland, WA 99352 \\ (509) 376-8157}

Responsible for the Hanford Site environmental management and restoration. 


\section{SAN FRANCISCO FIELD OFFICE (SF) \\ U.S. Department of Energy \\ John Belluardo, Acting Director \\ Office of Communications and Planning \\ 1301 Clay Street \\ Oakland, CA 94612 \\ (510) 637-6398 \\ FAX (510) 637-6434}

Established in 1952, the Office has a multi-program mission, including: defense programs; basic energy sciences; high energy and nuclear physics; environmental, safety and health; fusion research and development; nuclear energy and space research and development; environmental restoration and waste management activities; and conservation, renewable energy, and fossil energy programs. Specifically, SF administers contracts for the operation of laboratory and engineering facilities with a work force of approximately 13,000. SF's major facilities are: Lawrence Livermore National Laboratory (LLNL) and Lawrence Berkeley Laboratory (LBL), which are both managed by the University of California; Stanford Linear Accelerator Center, managed by Stanford University; and Energy Technology Engineering Center (ETEC), a component of Rockwell International, Rocketdyne Division.

\section{Lawrence Berkeley Laboratory University of California Arthur Tressler, Public Information Officer 1 Cyclotron Road, Building 50C Berkeley, CA 94720 \\ (415) 486-5771}

Founded in 1931 to advance the development of the cyclotron invented by Ernest Lawrence. Currently, the major roles of LBL are to perform multidisciplinary research in the general, energy, and life sciences; develop and operate unique national experimental facilities; educate and train the next generation of scientists and engineers; and foster productive relationships between LBL and industry. Research programs include high energy physics, materials science and chemistry, medical and biological science, energy conservation and storage, environmental science, medical and biological science, earth science, chemical biodynamics, instrumentation, and advanced accelerator design. The world's most advanced electron microscopes and medium energy particle accelerator are operated at LBL and are available for use by industrial and other researchers. In 1993, a unique source of synchrotron radiation, the Advanced Light Source, came online to serve a variety of researchers.
326

Lawrence Livermore National
Laboratory
University of California
Charles H. Biederman, Public Affairs
Director
P. O. Box 808, L-404
Livermore, California 94550
(415) 422-4599

Managed by the University of California for the U.S. Department of Energy, conducts research important to national goals, including national defense. Current research programs include weapons, energy, biomedicine and the environment. The Laboratory also has a longstanding commitment to protect the environment and enhance the Nation's economic competitiveness.

\section{Stanford Linear Accelerator Center Stanford University Michael Riodan, Assistant to the Director P. O. Box 4349 \\ Stanford, CA 94309 \\ (415) $926-2613$}

Built and operated by Stanford University, the Stanford Linear Accelerator Center is a national laboratory dedicated to research in elementary particle physics and to the uses of synchrotron radiation in science and industry. Experiments make use of a 2-mile linear accelerator that produces high-energy beams of electrons and positrons for collisions with stationary targets or with one another. Synchrotron radiation research in such fields as materials science, combustion dynamics, environmental pollution control, biology, and medicine is performed with beams of $x$-rays emerging from an electron storage ring known as SPEAR. The use of these facilities is open to researchers from both universities and industries, provided that the results are published in the open literature, such as scientific journals.

\section{SAVANNAH RIVER OPERATIONS OFFICE \\ U.S. Department of Energy \\ James Gaver, Director \\ Office of External Affairs \\ P.O. Box A \\ Aiken, SC 29802 \\ (803) $725-2889$}

As an element of the DOE nuclear weapons complex, the Savannah River Operations Office carries out: production of special nuclear materials, management of nuclear waste, production of naval fuels materials, and protection and management of environmental resources. 


\section{SCHENECTADY NAVAL REACTORS OFFICE (SNR) \\ U.S. Department of Energy \\ J. S. Cote, Public Information Officer \\ P.O. Box 1069 \\ Schenectady, NY 12301 \\ (518) 395-6379}

Negotiates and administers contracts for the operation of the Knolls Atomic Power Laboratory and for the procurement of fuel and cores required for the Naval Nuclear Propulsion Plant operation. SNR administers all technical and nontechnical aspects of these contracts. In addition, SNR serves as liaison with the Savannah River Operations Office of the Naval Propulsion Plant in connection with the construction and operation of the Naval Fuel Material Facility.

\section{Power Marketing Administrations}

Markets hydroelectric power generated at Federal multipurpose dams operated by the Army Corps of Engineers and the Bureau of Reclamation.

\section{Alaska Power Administration} Robert J. Cross, Administrator 2770 Sherwood Lane, Suite 2B Juneau, AK 99801-8545 (907) 586-7405

331 Bonneville Power Administration Randall W. Hardy, Administrator P.O. Box 3621

Portland, OR 97208

(503) 230-5101
BPA Washington, DC, Office

Steven J. Wright, Assistant Administrator Room 8G-033, Forrestal (202) 586-5640

332 Southeastern Power Administration John A. McAllister, Jr., Administrator Samuel Elbert Building Elberton, GA 30635-2496 (404) 283-9911

333 Southwestern Power Administration J. M. Shafer, Administrator

P.O. Box 1619

Tulsa, OK 74101

(918) $581-7476$

FTS (918) 745-7530

Washington, DC, Office

Rodney Adelman, Liaison Offices

Room 8E-026, Forrestal

(202) 586-2008

334 Westem Area Power Administration William Clagett, Administrator

P.O. Box 3402

1627 Cole Boulevard

Golden, CO 80401

(303) 231-1513

Washington, DC, Office

Ronald K. Greenhalgh, Assistant

Administrator

Room 8G-061, Forrestal

(202) $586-5581$ 


\section{Federal Government Agencles}

\section{Department of Agriculture}

\section{Economic Research Service Input, Supply and Demand Section Production System Branch 1301 New York Avenue, N.W., Room 424 Washington, DC 20005-4788 \\ Mohinder Gill, Agriculture Economist (202) 219-0459}

Provides current and historical statistics on energy use, prices, and expenditures in agriculture by fuel source, such as gasoline, diesel, liquefied petroleum gas, fuel oil, etc. The Office also provides information on grain-based fuel alcohol, including supply demand, economics, capacity, imports, and energy-related legislation, particularly that affecting alcohol fuels.

\section{Forest Service \\ P. O. Box 96090 \\ Washington, DC 20090-6090 \\ Thomas E. Hamilton, Associate Deputy \\ Chief for Research \\ (202) 205-4507}

David G. Unger, Associate Deputy Chief for the National Forest System

(202) 205-6677

Allen J. Schacht, Associate Deputy Chief for State and Private Forestry

(202) 205-3331

\author{
Howard Rosen, Energy Coordinator \\ Forest Products and Harvesting Research \\ Staff \\ USDA, Forest Service \\ 14th \& Independence Avenue, S.W. \\ P.O. Box 96090 \\ Washington, DC 20090-6090
}

Conducts forest biomass energy-related research. The agency coordinates its research activities with Federal and State agencies, as well as universities. Activities include obtaining, analyzing, and projecting national statistics on woody biomass supply and use, as well as research in silviculture, harvesting, and utilization. The Agency also administers national forest lands in a multiple-use approach that includes sales of industrial wood and personal/industrial use of fuel wood.

\section{Rural Electrification Administration 14th and Independence Avenue, S.W. Washington, DC 20250 \\ Legislative and Public Affairs Staff (202) 720-1255}

Makes loans to finance electric and telephone facilities in rural areas. These loans finance construction and operation of generating plans and transmission and distribution lines to provide initial and continued adequate electric service in rural areas. Loans are repaid by borrowers from their operating revenues.

\section{Department of Commerce}

\section{Bureau of Census Foreign Trade Division Federal Building 3, Room 2179 \\ Washington, DC 20233 \\ For trade data: \\ (301) 763-5140}

Provides statistical information on U.S. exports and imports merchandise trade.

\section{Bureau of Economic Analysis 1401 K Street, N.W. Washington, DC 20230 \\ Barbara Howenstine, Information Officer (202) 523-0777}

Plays a major role in the measurement and analysis of U.S. economic activity. The Bureau provides a clear picture of the economy through the development, preparation, and interpretation of the economic accounts of the United States. The accounts provide a quantitative view of the economy's production and distribution, as well as the use of the Nation's output. Featured economic estimates include GDP, personal income, and the index of leading economic indicators. The Bureau's monthly journal, the Survey of Current Business, is available from GPO. The Bureau's other publications are available through GPO and NTIS. 
Import Administration

Office of Capital Goods and International

Construction

Main Commerce Building

Room 2107

Washington, DC 20230

Heavy Equipment Division

(202) 377-0680

Provides industry shipments and trade data of mining machinery.

\section{International Trade Administration}

14th and Constitution Avenue, N.W.

Room 4045

Washington, DC 20230

Vincent J. Kamenicky, Director

Office of Chemicals and Allied Products

(202) 377-0128

FAX (202) 377-8836

Leo R. McIntyre, Chemical Industry

Specialist

(202) 377-0128

FAX (202) 377-8836

Serves as the principal resource for chemical and petrochemical analysis and information in the Department of Commerce. The Office monitors the industry structure, production, capacity, prices, and other economic factors, both domestic and international. Analytical results are used both within the Department of Commerce for policy planning and by industry and other Government agencies. The Office also is responsible for the competitive assessment programs, policy and legislation, and export promotions.

\section{Office of Energy, Environment, and Infrastructure Energy Division \\ Room 4413 \\ Washington, DC 20230}

Joe Yancik, Director

Basic Industries Sector Trade Development (202) $482-1466$

The primary role of the Office of Energy is to foster and assist the basic enargy fuels industries (coal, oil, natural gas, uranium renewable $f$,els, and electric power generation) and to improve their market competitiveness and participation in international trade.
343 Office of Energy, Environment, and

Infrastructure

Power and Construction Equipment Branch

Room 4324

Washington, DC 20230

Edward McDonald

Industry Specialist

(202) 482-0680

Monitors the mining machinery and petroleum equipment industries. Provides industry shipment and trade data and develops trade policy and export promotion programs.

\section{National Institute of Standards and Ter.hnology Gaithersburg, MD 20899 \\ George Lewett, Chief \\ (301) $975-5500$ \\ FTS 879-5500 \\ Sandy Wean (for program information) \\ (301) $975-5500$ \\ FTS 879-5500}

Provides for evaluation of ideas and inventions to determine their technical and commercial feasibility, energy conservation or supply value, and practicality; for is recommendations for DOE funding if the t is promising. Applicants must submit a c chnical description of the invention and $\mathrm{CO}_{1}$. the Energy-Related Inventions Evaluation Report Form (NBS-1019); the review process takes from 2 to 8 months. This Office works in conjunction with the DOE Energy-Related Inventions Program.

\section{National Oceanic and Atmospheric Administration (NOAA) National Climatic Dasa Center Dr. Kenneth Hadeen, Director Federal Building Asheville, NC 28801-2696 \\ For climate data, call: (704) 259-0682 FTS 672-0682}

Provides, for the cost of reproduction (minimum charges begin at $\$ 13.00$ ), available climatic summaries for sites in or near a locality. Climatic summaries for major U.S. weather stations, including wind data, are available in different forms, some more detailed than 
others. Detailed summaries include wind variation by hour of day and month of year. Wind tabulations that present the percentage frequency of wind direction and wind-speed groups have been constructed for many of the weather stations. In addition, the Office has available solar insolation data for a number of cities in the United States. Special studies involving wind and/or solar insolation may be produced upon request. Machine-readable data are also available.

\section{National Technical Information Service (NTIS) 5285 Port Royal Road Springfield, VA 22161 1-800-553-6847}

Provides access to the results of both U.S. and foreign government-sponsored research and development and engineering activities. As the central source for U.S. Government scientific and technical information, NTIS announces through its information products more than 150,000 summaries of ongoing and completed U.S. and foreign government-sponsored research and development and engineering activities annually(these summaries detail the knowledge and technology generated through U.S. Government's multibillion dollar research and development effort); provides the complete technical reports for most of the results it announces; and manages the Federal Computer Products Center. This Center also provides access to software, data files, and data bases produced by Federal agencies; manages the Center for the Utilization of Federal Technology (CUFT), which prepares a variety of directories, catalogs, and other information products linking U.S. firms to key and selected Federal lab technologies, inventions available for licensing, and contacts; and annually provides U.S. firms access to the worldwide results of more than 15,000 foreign government-sponsored research and engineering programs. NTIS is the lead U.S. Government agency for cooperation in technical information exchange. Through agreements with hundreds of organizations, new research and development efforts are announced from countries such as Japan, West Germany, Great Britain, France, and other leading industrialized nations. For a free copy of the NTIS Products and Services Catalog, call (703) 487-4650 and request catalog \#PR-827.

\section{Department of Defense}

\section{Office of Assistant Secretary for Defense for Production and Logistics Directorate for Energy Policy Jeffrey A. Jones, Director The Pentagon, Room 1D760 Washington, DC 20301-8000}

(703) 697-5981

FTS 697-9419

Millard Carr, Assistant for Energy Policy

(703) 697-5981

FTS 697-9419

Edward J. Dyckman, Assistant for Energy

Resource Management

(703) 697-5981

FTS 697-9419

James Carnes, Assistant for Energy

Systems and Analysis

(703) 697-5981

FTS 697-9419

Col. Larry Dipoma, USAF

Assistant for Petroleum Logistics

(703) 697-5981

FTS 697-9419

\section{Energy Resource Management and Conservation}

Reduces energy use through efficiency investments, incentives, and engineering; develops energy use and management policies that achieve environmental goals--e.g., clean air, clean water, solid and hazardous waste minimization; and develops and cosponsors emerging energy technologies for a variety of security, environmental, and economic goals.

\section{Energy Supply, Availability, and Cost}

Improves energy acquisition and supply methods, including bulk petroleum supply and centralized natural gas and coal purchasing; develops electric utility policies on source selection, cogeneration, cost reduction, and demand management to meet clean air goals; improves supply security, including energy infrastructure, vulnerabilities and national crisis response actions; manages information to measure progress against goals.

\section{Department of Health and Human Services}

\section{Office of Community Services \\ Administrat on for Children and Families Mary Jo Bane, Assistant Secretary 370 L'Enfant Promenade, S.W. Washington, DC 20447 (202) 401-9200}

Administers the Low Income Home Energy Assistance Program (LIHEAP) block grants to the States, Indian tribes, and U.S. territories to assist low-income households with home energy rosts through heating and cooling assistance, cissis assistance, and weatherization assistance. 


\section{Department of Housing and Urban Development}

\section{Office of Environment and Energy \\ Robert Groberg, Director \\ Wyndham Clarke, Deputy Director \\ Energy Division \\ 451 7th Street, S.W., Room 7244 \\ Washington, DC 20410 \\ (202) 708-2504 \\ FTS 458-2504}

Serves as HUD's principal coordinator for energy activities and provides advice and staff support on energy matters affecting State and local governments and the general public; provides technical assistance to State and local governments in achieving the energy objectives of programs administered by the Department, including the Community Development Block Grai,t Program and the Affordable Housing Act programs.

The Division administers and participates in demonstrations, feasibility studies, and cooperative efforts with the Department of Energy and other agencies in such diverse areas as energy efficiency of buildings, economic/community development, district heating, municipal waste-to-energy systems, energy and the elderly, and sustainable development.

\section{HUD USER \\ P. O. Box 6091 \\ Rockville, MD 20850 \\ (301) 251-5154 \\ 1-800-245-2691}

Operates a computer-based information service created by the Department of Housing and Urban Development (HUD). The HUD USER provides literature searches from HUD's data base, summaries of HUD research results, special products, and document distribution service. In the data base collection, energy and utilities information is included. Other information includes, but is not limited to, building technology, community development/public finance, elderly and handicapped, environmental research, housing finance, housing management, and housing programs. HUD USER does charge for service and handling of information and documents; make checks payable to HUD USER.

\section{Department of Interior}

\section{Bureau of Land Management (BLM) Hillary Oden, Assistant Director Energy and Mineral Resources}

Organization Code: BLM 600

1849 C Street, N.W., Room 5627

Washington, DC 20240

(202) 208-4201

\author{
Adam A. Sokoloski, Deputy Assistant \\ Director (for program information) \\ Energy and Minerals \\ Room 5627 \\ (202) 208-4201
}

Responsible for the on-shore leasing program, resource evaluation, and classification functions; environmental review of leasing activities; regulation for operations and lease management; and inspection and enforcement activities for all on-shore leasable minerals.

\section{Minerals Information Office 1849 C Street, N.W., Room 2647-MIB Washington, DC 20240}

\section{Mineral and Mining Information} (202) 208-5520

\section{Geological Information}

(202) 208-5512

The Minerals Information Office (MIO) is a cooperative endeavor of the U.S. Geological Survey (USGS) and the U.S. Bureau of Mines for mineral resource inquiries. Mineral experts provide information and access to USGS and Bureau of Mines data bases, commodity specialists, and publications for the benefit of public, industry, and State and Federal officials. The Office also seeks to improve the exchange of information among the Federal agencies and other mineralsinformation generators and users.

\section{Minerals Management Service Carolita U. Kallaur, Acting Director 1849 C Street, N.W., Room 4210 Washington, DC 20240 (202) 208-3500}

Responsible for the offshore leasing program, resource evaluation, and classification functions; environmental review of leasing activities; regulation of operations and lease management; and inspection and enforcement activities for all leasable minerals on the Outer Continental Shelf (OCS). In addition, the Service is responsible for the collection of all royalty payments, rentals, bonus payments, fines, penalties, and assessments and for other revenues due the Federal Government and Indian lessors as monies or royalties-in-kind from the extraction of mineral resources from Federal and Indian lands on-shore and from the 
leasing and extraction of mineral resources on the OCS.

\section{Office of Surface Mining Reclamation and Enforcement Gene Krueger, Chief \\ Division of Abandoned Mine Land \\ Reclamation \\ 1951 Constitution Avenue, N.W., Room 120 \\ Washington, DC 20240 \\ (202) 208-5365}

Formulates policy for State, Federal, and Indian Abandoned Mine Land (AML) reclamation programs, and develops annual work plans. Develops grant distributions to the States and Tribes from the AML Reclamation Fund. Provides guidance for monitoring and evaluating Federal and State/Tribal AML programs for establishing programmatic requirements for AML grants and for administering emergency reclamation responsibilities. Maintains an inventory and tracking system for projects funded from the AML Reclamation Fund. Coordinates the Office of Surface Mining Reclamation anci Enforcement's Value Engineering activities.

\section{Division of Technical Services John Mosesso, Chief 1951 Constitution Avenue, N.W. Room 640NC Washington, DC 20240 \\ (202) $343-1480$}

Responsible for Office of Surface Mining Reclamation and Enforcement (OSM) compliance with the National Environmental Policy Act. The division is also responsible for all economic analyses performed by OSM, administration of the applied research program, technical training, and the development of regulations.

\section{Bureau of Mines \\ Office of International Data Section 2401 E Street, N.W., Room 404, MS 5242 Washington, DC 20241-0001 \\ George J. Coakley, Chief Division of International Minerals (202) 632-8970 \\ FTS 634-1112/1115}

Collects and publishes data in the Bureau of Mines' Minerals Yearbook. Primary areas are international production and foreign trade for all fuel and allied products.
357 U. S. Geological Survey (USGS)

Geologic Inquiries Group (GIG)

907 National Center

Reston, VA 22092

(703) 648-4383

FTS 959-4383

Answers questions on all aspects of geology. This Office answers questions on topics such as earthquakes, volcanoes, energy resources, the geology of specific areas, and geologic maps and mapping. Information on geologic map indexes and a limited number of copies are also available from GIG. Both written and telephone requests are handled by this Office or are referred to the appropriate information source.

Distribution Branch
Map Sales
Box 25286, DFC
Denver, CO 80225
(303) 236-7477
FTS 776-7477

Distributes maps of energy resources in the United States. The maps vary in price. Contact this office for an index of map titles and ordering information. Topographic maps are available.

\section{Information Systems Division \\ 802 National Center \\ Reston, VA 22092}

\section{Earth Science Data Directory \\ Project Manager \\ (703) 648-7112 \\ FTS $959-7112$}

Offers online access to a USGS mainframe computer repository about earth-science and natural-resource data bases. A directory is also available on compact disc. Data bases referenced in the directory include those concerned with the geologic, hydrologic, cartographic, and biologic sciences. References to data bases that support the protection and management of natural resources are also included. Geographic, sociologic, economic, and demographic data bases are among those cataloged. Arctic region data base entries are included in the Arctic Environmental Data Directory as a subset. The directory is the repository of information on Department of Interior data bases related to interagency global change activities. A full range of data sources offer potential leads to base and / or overlay input for geographic information system (GIS) applications. The directory also includes some references to GIS product data bases. 


\section{Department of Labor}

\author{
358 Bureau of Labor Statistics \\ Consumer Price Index \\ 600 E Street, N.W. \\ Washington, DC 20212 \\ Bob Adkins, Economist \\ (202) 606-6985 \\ Joe Chelena, Economist \\ (202) 606-6982
}

Provides monthly prices for residential consumption of natural gas, electricity, fuel oil, and gasoline. Prices are averaged for 15 U.S. cities and Standard Metropolitan Statistical Areas (SMSA), reflecting different geographic areas and population categories. Price indices for natural gas, fuel oil, gasoline, and other fuels are also available.

\section{Division of Monthly Industry Employment Statistics \\ 2 Massachusetts Avenue, N.E., Suite 4860 \\ Washington, DC 20212 \\ Lois Plunkert, Branch Chief \\ (202) 606-6555}

Compiles and publishes monthly statistics on the number, work hours, and earnings of employees in various industries, including energy industries.

360

\author{
Mine Safety and Health \\ Administration (MSHA) \\ Office of Information \\ Wayne Veneman, Director \\ 4015 Wilson Boulevard \\ Room 601 \\ Arlington, VA 22203 \\ (703) 235-1452
}

Provides information on a wide variety of mine safety topics. Responsible for responding to information requests from media and the public. Various fact sheets are available on such subjects as coal mine safety and health activities. Provides inquiry assistance in conjunction with other MSHA policy, education programs related to mine safety and training.

\section{Department of Transportation}

\author{
361 Office of Economics \\ 400 7th Street, S.W., Room 10305 \\ Washington, DC 20590
}

Donald J. Igo, Assistant for Energy Policy (202) 366-0783

Provides support for the development of transportation energy policy and provides review of major energy policy issues arising in various Department of Transportation programs.

\section{Office of Regulatory Affairs 400 7th Street, S.W., Room 9217 Washington, DC 20590
Nancy Ebersol, Program Analyst (202) 366-4864
FTS 426-4864

Provides information from the interim (1974) and final (1975) reports to Congress on the operation and effects of daylight saving time experiments in energy use and on other factors.

\section{Federal Highway Administration Office of Highway Information Management David R. McElhaney, Director 400 7th Street, S.W. Washington, DC 20590 (202) 366-0180}

Compiles and publishes statistics on highway use of motor fuels, including total use of gasoline; vehicle registration and driver's licenses issued; financing of Federal, State and local highway systems; mileage of roads and streets, including type of pavement; traffic and travel characteristics, including vehicle-miles traveled. Most data are by State.

\section{Highway Traffic Safety Administration Office of Enforcement and Emergency Services 400 7th Street, S.W., Room 5119 Washington, DC 20590 \\ Susan D. Ryan, Acting Director NTS-40 \\ (202) 366-4913 \\ Fax: (202) 366-7721}

This Office houses two services: the Police Traffic Services and the Emergency Medical Services. The Police Traffic Services is a clearinghouse and informatinn center for enforcement programs in the States. This Service designs and develops countermeasure and training programs to assist State and local agencies, particularly in the area of safety belt usage, Driving While Intoxicated (DWI), speeding, and other hazardous violation enforcement. Oversees the enforcement of the National Maximum Speed Limit. The Emergency Medical Services engages in research 
and development of programs for use by State and local agencies in the delivery of treatment of highway collision patients, with special emphasis on trauma care. This Service also develops programs for emergency communications and methods for the evaluation of treatment delivery.

\section{Office of Technology Sharing, DTS-31 Transportation Systems Center Kendall Square Cambridge, MA 02142 \\ R. V. Giangrande, Chief (617) 494-2486 \\ FTS 837-2486}

Serves as the national research and development center for transportation systems design and for evaluative studies on various kinds of transportation programs. It has information on urban and community transportation programs; paratransit systems; 'dial-a-transit' programs; air, rail, and mass transit programs; transportation for the elderly and handicapped; and energy conservation in transit programs.

\section{Research and Special Programs Administration Policy Development and Information Systems Division 400 7th Street, S.W., Room 8112 Washington, DC 20590}

Sadie Willoughby, Information Systems Specialist Information Systems Branch

DHM-63

(202) $366-4555$

Serves as a centralized computer-maintained management information system supporting the multimodal transportation of hazardous materials. The Hazardous Materials Information System (HMIS) provides direct retrieval, through six major subsystems, of the available information on incident data, inspectior/en- forcement results, indexes of regulations, interpretation of regulations, status of approvals, and status of exemptions. Requests for information will be honored. Limited direct access can also be arranged.

\section{Department of Treasury}

\author{
367 Bureau of Alcohol, Tobacco, and \\ Firearms (ATF) \\ Washington, DC 20226 \\ John C. Killorin, Chief \\ Public Affairs Branch \\ (202) 566-7135
}

Maintains pamphlets and fact sheets about the Bureau's history and responsibilities. The Office provides ATF news releases and information about Federal laws and ordinances that affect trade in and licensing of alcohol, tobacco, firearms, and explosives.

\section{Federal Taxpayers Service Line Internal Revenue Service Department of the Treasury}

Provides information on tax problems including energy-related taxes and tax credits. For the toll-free number in your locality, consult the telephone directory under "U.S. Government, Department of the Treasury, Internal Revenue Service."

\section{Statistics of Income Division Internal Revenue Service 500 North Capitol Street, N.W. P.O. Box 2608 Washington, DC 20013 \\ Dr. Fritz Scheuren, Director (202) 874-0700}

Produces statistics on energy-related industries and on the Nonconventional Source Fuel Credit. 


\section{Federal Government Legislative Branch}

\section{United States Senate}

\section{Committee on Energy and Natural Resources \\ Majority Staff \\ 364 Senate Dirsken Office Building \\ Washington, DC 20510-6150 \\ (202) 224-4971}

Minority Staff

312 Senate Dirsken Office Building

(202) 224-1017

Consists of 20 Senators responsible for all proposed legislation, messages, petitions, memorials, and other matters relating to the following subjects: (l) coal production, distribution, and utilization; (2) energy policy; (3) energy regulation and conservation; (4) energy related aspects of deepwater ports; (5) energy research and development; (6) extraction of minerals from oceans and Outer Continental Shelf lands; (7) hydroelectric power, irrigation, and reclamation; (8) mining education and research; (9) mining, minera! lands, mining claims, and mineral conservation; (10) national parks, recreation areas, wilderness areas; wild and scenic rivers, historical sites, military parks and battlefields, and the public domain; preservation of prehistoric ruins and objects of interest; (11) naval petroleum reserves in Alaska; (12) nonmilitary development of nuclear energy; (13) oil and gas production and distribution; (14) public lands and forests, including farming and grazing thereon, and mineral extraction therefrom; (15) solar energy systems; (16) territorial possessions of the United States, including trusteeships.

\section{1 subcommittee on Energy Regulation and Conservation Majority Staff \\ 212 Senate Dirsken Office Building Washington, DC 20510-6152 (202) 224-4971 \\ Minority Staff \\ 312 Senate Dirsken Office Building (202) 224-1017}

Responsible for oversight and legislative issues for Federal energy conservation programs; energy; information; commercialization of new technolorgies (e.g., wind, solar, ocean thermal energy conversion); liquified natural gas projects; oil and gas pirelines and pipeline regulation, including regulation of Alaska Natural Gas Transportation System, Trans Alaska Pipeline System, and other oil or gas pipeline transportation systems within Alaska (e.g., the Trans-Alaskan Gas line system); regulatory functions of ERA; refinery policy; gasoline rationing; emergency preparedness; petroleum allocation; and coal conversion.

\section{2 subcommittee on Energy Research and Development \\ Majority Staff \\ 312 Senate Dirsken Office Building \\ Washington, DC 20520-6154 \\ (202) 224-4971}

Minority Staff

312 Senate Dirsken Office Building

(202) 224-1017

Responsible for oversight and legislative issues for nuclear research and development; coal and synfuels research and development; nuclear and nonnuclear energy commercialization projects; nuclear fuel cycle policy, including uranium resources; new technologies research and development; nuclear facilities siting; and breeder reactor development.

\section{Subcommittee on Mineral Resources Development and Production Majority Staff 362 Senate Dirsken Office Building Washington, DC 20510-6156 (202) 224-4971 \\ Minority Staff 312 Senate Dirsken Office Building (202) 224-1017}

Responsible for oversight and legislative issues for energy and nonfuel mineral resources; Federal mineral leasing; national mining anci minerals policy and general mining laws; surface mining, reclamation and enforcement; coal production, distribution and utilization; oil and gas production and distribution; mining education and research; minerals exploration, development and production from public and acquired lands; mineral conservation; royalty management; coal severance tax; Naval Petroleun and Oil Shale Reserves; deepwater ports; and deep seabed mining. 


\section{4 subcommittee on Public Lands, National Parks and Forests Majority Staff \\ 308 Senate Dirsken Office Building \\ Washington, DC 20510-6158 \\ (202) 224-4971 \\ Minority Staff \\ 312 Senate Dirsken Office Building \\ (202) 224-1017}

Responsible for oversight and legislative issues for the public lands administered by the Bureau of Land Management; National Forest System; National Park System; National Wilderness Preservation System; Wild and Scenic Rivers System; National Trails System; establishment of wildlife refuges on public lands; Alaska Native Claims Settlement Act; Alaska National Interest Lands Conservation Act; reserved water rights; military land withdrawals; national recreation areas; national monuments; historic sites; military parks and battlefields; Land and Water Conservation Fund; historic preservation; renewable resources; outdoor recreation resources; and on the public domain, preservation of prehistoric ruins and objects of interest.

\section{Subcommittee on Water and Power Majority Staff 306 Senate Dirsken Office Building Washington, DC 20510-6156 \\ (202) 224-4971 \\ Minority Staff 312 Senate Dirsken Office Building (202) 224-1017}

Responsible for oversight and legislative issues for irrigation; reclamation projects, including related flood control purposes; power marketing administrations (e.g., Bonneville Power, Alaska Power, Southwestern Power, Western Area Power; Southeastern Power); energy development impacts on water resources; groundwater resources and management; small power producers; hydroelectric power; and low lead hydro.

\section{United States House of Representatives}

\author{
376 Committee on Energy and Commerce \\ Majority Staff \\ 2125 Rayburn House Office Building
}

\author{
Washington, DC 20515 \\ (202) 225-2927 \\ Minority Staff \\ 2322 Rayburn House Office Building \\ (202) 225-3641
}

Consists of $\mathbf{4 3}$ members with responsibilities as follows: (1) interstate and foreign commerce, generally; (2) national energy policy generally; (3) measures relating to the exploration, production, storage, supply, marketing, pricing, and regulation of energy resources, including all fossil fuels, solar energy, and other unconventional or renewable energy resources; (4) measures relating to the conservation of energy resources; (5) measures relating to the commercial application of energy technology; (6) measures relating to energy information generally; (7) measures relating to the generation and marketing of power (except by federally chartered or Federal regional power marketing authorities); the generation and interstate transmission of, and ratemaking for, all power; and the siting of generation facilities, except the installation of interconnections between Government waterpower projects; (8) interstate energy compacts; (9) measures relating to general management of the Department of Energy, and the management and all functions of the Federal Energy Regulatory Commission; (10) inland waterways; (11) railroads, including railroad labor, railroad retirement and unemployment, except revenue measures related thereto; (12) regulation of interstate and foreign communications; (13) securities and exchanges; (14) consumer affairs and consumer protection; (15) travel and tourism; (16) public health and quarantine; (17) health and health facilities, except health care supported by payroll deductions; and (18) biomedical research and development.

\section{Subcommittee on Energy and Power Majority Staff 331 Ford House Office Building Washington, DC 20515-6120 (202) 226-2500 \\ Minority Staff \\ 564 Ford House Office Building (202) 226-3400}

Responsible for national energy policy; fossil energy and renewable energy resources; synthetic fuels and energy conservation; energy regulation, commercialization and utilization; utility issues and regulation of nuclear facilities; and, all laws, programs and Government activities affecting matters of nuclear energy. 


\section{Independent Agencies}

\section{Environmental Protection Agency}

\author{
378 Indoor Air Quality Information \\ Clearinghouse \\ P. O. Box 37133 \\ Washington, DC 20013-7133 \\ (800) 438-4318 \\ (301) 585-9020 \\ FAX (301) 588-3408
}

A central source of information in indoor air quality, created and supported by the U.S. Environmental Protection Agency. The purpose of the office is to answer questions about indoor air pollution and or make referrals.

\section{9 office of Air Quality}

Planning and Standards

Technical Support Division

National Air Data Branch

Research Triangle Park, NC 27711

Jake Summers, Data Administrator

Air Quality Subsystems

(919) $541-5582$

H. Wright, Data Administrator
Air Facility Subsystems
(919) 541-5584
Tom Link, Coordinator
Data Retrievals
(919) 541-5456

Provides emissions data and background information on air quality and air facility subsystems.

\section{Office of Federal Activities \\ Dawn Roberts \\ 401 M Street, S.W., Room 2119M, A-104 \\ Washington, DC 20460 \\ (202) 260-5073}

Maintains the Council on Environmental Quality filing system of Environmental Impact Statements (EIS's) that have been submitted by sponsoring agencies. It also controls the records of all EIS reviews by the Environmental Protection Agency.

\section{U.S. International Trade Commission}

\author{
381 U.S. International Trade Commission \\ Energy, Chemicals, and Textiles Division \\ 500 E Street, S.W. \\ Washington, DC 20436 \\ (202) 205-3342
}

Energy related activities of the Commission include the monitoring of production, sales, and international trade of petroleum, natural gas, coke and coal, uranium, and electricity. In addition, the Commission follows developments in biomass and solar and hydropower for energy production, and collects and publishes data on U.S. productic $n$ and sales of all synthetic organic chemicals, including alternate energy sources, such as alcohols and oxygenates.

\section{Nuclear Regulatory Commission}

\section{Office of Public Affairs Washington, DC 20555 (301) 504-2240}

Serves as a public inquiry point for information on licensing (including decommissioning) of commercial nuclear power plants and other nuclear facilities and the possession and use of nuclear materials for medical, industrial, educational, and research purposes; inspections and investigations designed to assure that licensed activities are conducted in compliance with the Agency's regulations and other requirements; confirmatory research in the areas of safety, safeguards, and environmental assessment and the establishment of regulations, standards, and guidelines governing the civilian use of nuclear facilities and materials; safeguarding of nuclear facilities and materials from diversion or sabotage; implementation of Agency responsibilities under the Nuclear Waste Policy Act of 1982 (high-level radioactive wastes), as amended in 1987, and the Low-Level Radioactive Waste Policy Act of 1980, as amended in 1985, and the Uranium Mill Tailings Radiation Control Act of 1978; and packaging of radioactive materials for transport. 


\section{Tennessee Valley Authorlty}

\section{Forest Resources Development Program \\ Larry N. Hamner, Chief Forester \\ Forestry Building \\ Norris, TN 37828 \\ (615) 632-1631}

Conducts research and maintains data bases on forest biomass resources of the seven-State, 201-county Tennessee Valley region. The Forest Industry Data System (FIND) contains information on wood residue production and use by county, the location and size of wood fuel combustion facilities, and electrical production capacity. The Forest Resources Information System (FRIS) contains information about standing forest resources in the TVA region and is used to estimate potential energy wood availability, as well as to answer requests on forest growth and harvesting trends in the region. Technical assistance is provided on biomass combustion options, biomass harvesting, and wood drying.

\section{U.S. General Accounting Office}

\section{U.S. General Accounting Office \\ Victor S. Rezendes, Director \\ Energy and Science Issue Area, Resources, Community, and Economic Development \\ Division \\ Room 1842 \\ 441 G Street, N.W. \\ Washington, DC 20548 \\ (202) $512-3841$}

Jim Wells, Associate Director

Energy and Science Issue Area, Resources,

Community, and Economic Development

Division

111 Massachusetts Avenue, N.W., Suite 201

Washington, DC 20001

(202) $512-6868$

\section{Publications Ordering \\ P.O. Box 6015 \\ Gaithersburg, MD 2n877}

The U.S. General Accounting Office (GAO) is a nonpartisan legislative branch agency that assists Congress, its commurit' $s$, and members in their legislative and oversig it work. GAO's Energy Issue Area conducts in-depth studies of the production, regulation, and consump ion of all forms of energy. Aspects of GAO's energy work include evaluating the effectiveness of energy security policies and programs; the management of :nergy research and devel- opment programs and nuclear waste disposal programs; the safety of defense and commercial nuclear facilities; and the procedures and controls governing energy programs. Publications available include Energy and Science: Reports and Testimony for 1992 (GAO/RCED-93-131). Also available are GAO's Monthly List of Reports and Testimonies and GAO's Annual Index: Reports Issued in FY 1992. Call (202) 5126241 or write to the Publications address above. The first five copies of each GAO report are free. Additional copies are $\$ 2$ each.

\section{U.S. Government Printing Office}

\section{U.S. Government Printing Office (GPO) \\ Superintendent of Documents \\ Washington, DC 20402 \\ (202) 783-3238}

Handles the public sale of Federal Government publications, including selected DOE and EIA statistical, technical, and educational publications. General publications on energy and other areas of interest to the consumer are also available. The bookstores quote prices and availability on phone and mail requests and also will obtain publications not on hand at time of request. The bookstores respond to requests from all 50 States and from requestors in foreign countries. Telephone orders are accepted only from those with a GPO account, Visa, Mastercard; remittance in the form of a check or money order must accompany all other orders. Free subject bibliographies are available on request.

\section{GPO Bookstores and Retail Sales Branch}

Atlanta Bookstore

Room 100, Federal Building

275 Peachtree Street, N.E.

P. O. Box 56445

Atlanta, GA 30343

(404) 311-6947

Birmingham Bookstore

O'Neill Building

2021 3rd Avenue North

Birmingham, AL 35203

(205) 731-1056

\section{Boston Bookstore}

Thomas P. O'Neill Federal Building

10 Causeway Street, Room 169

Boston, MA 02222

(617) $565-6680$ 
Chicago Bookstore

Room 1365, Federal Building

219 S. Dearborn Street

Chicago, IL 60604

(312) 353-5133

\section{Cleveland Bookstore}

Room 1653, Federal Building

1240 East 9th Street

Cleveland, $\mathrm{OH} 44199$

(216) $522-922$

Columbus Bookstore

Room 207, Federal Building

200 N. High Street

Columbus, $\mathrm{OH} 43215$

(614) 469-6956

Dallas Bookstore

Room 1C46, Federal Building

1100 Commerce Street

Dallas, TX 75242

(214) 767-0076

Denver Bookstore

Room 117, Federal Building

1961 Stout Street

Denver, CO 80294

(303) 844-3964

Detroit Bookstore

Suite 160, Federal Building

477 Michigan Avenue

Detroit, MI 48226

(313) 226-7816

\section{Houston Bookstore}

Texas Crude Building

801 Travis Street

Houston, TX 77002

Jacksonville Bookstore

Room 158, Federal Building

400 West Bay Street

Jacksonville, FL 32202

(904) 791-3801

Kansas City Bookstore

120 Bannister Mall

5600 East Bannister Road
Kansas City, MO 64137

(816) 765-2256

\author{
Laurel Retail Sales Outlet \\ 8660 Cherry Lane \\ Laurel, MD 20707 \\ (301) 951-7974
}

Los Angeles Bookstore ARCO Plaza, C-Level 505 South Flower Street Los Angeles, CA 90071

Main Bookstore

710 North Capitol Street, N.W. Washington, DC 20401 (202) 275-2091

McPherson Square Bookstore 1510 H Street, N.W.

Washington, DC 20005

(202) 653-5075

Milwaukee Bookstore Room 190, Federal Building $517 \mathrm{E}$. Wisconsin Avenue Milwaukee, WI 53202

(414) 294-1304

New York Bookstore

Room 110, Federal Building

26 Federal Plaza

New York, NY 10278

(212) 264-3825

Philadelphia Bookstore Robert Morris Building 100 North 17th Street Philadelphia, PA 19103 (215) 597-0677

Pittsburgh Bookstore Room 118, Federal Building 1000 Liberty Avenue Pittsburgh, PA 15222 (412) $644-2 / 21$

Portland Bookstore 1305 S. W. First Avenue Portland, OR 97201-5801 (503) 221-6217 
Pueblo Bookstore

World Savings Building

720 North Main Street

Pueblo, CO 81003

(719) 544-3142

San Francisco Bookstore

Room 1023, Federal Building

450 Golden Gate Avenue
San Francisco, CA 94102

(415) 252-5334

Seattle Bookstore

Room 194, Federal Building

915 Second Avenue

Seattle, WA 98174

(206) 553-4270 


\section{State Governor Offlces, State Energy Offices, State Oil and Gas Agencles, State Geologist, and Public Service Commissions}

The following lists for each State the Governor, the State Energy Office or equivalent, State Oil and Gas Agency, State Geologist, and the Public Utility Commission or equivalent. Public utility commissions (sometimes referred to as public service commissions) are responsible for the economic regulation of utilities. The goal of regulation is to ensure provision of safe and reliable service at just, reasonable and sufficient rates.

\section{Alabama}

Governor Jim Folsom, Jr.

Alabama State House

,11 South Union Street, Room 217

Montgomery, AL 36130

(205) 242-7100

State Energy Office

K. David Shropshire

Division Chief

Department of Economic and Community

Affairs Science Technology and Energy Division

P.O. Box 5690

Montgomery, AL 36103-5690

(205) 242-5292

State Geologist

Ernest A. Mancini

Alabama Geological Survey

P. O. Box O

Tuscaloosa, AL 35486-9780

(205) 349-2852

FAX: (205) 349-2852, Ext. 294

State Oil and Gas Agency

Ernest A. Mancini

Oil and Gas Supervisor

State Oil and Gas Board

P. O. Box O

Tuscaloosa, AL $35486-9780$

(205) 349-2852

Fax: (205) 349-2852, Ext. 294

Public Service Commission

J. W. Tidmore, Secretary
One Court Square

Montgomery Street

P.O. Box 991

Montgomery, AL 36101-0991

(205) 242-5218

387 Alaska

Governor Walter J. Hickel

State Capitol

Pouch A

Juneau, AK 99811

(907) $465-3500$

State Energy Office

Steve Baden, Chief

Affordable Housing \& Energy Efficiency Department

Alaskan Housing Finance Corporation

520 East 34 th Avenue

Anchorage, AK 99503

(907) 269-4500

State Geologist

Thomas E. Smith

Alaska Geological Survey

794 University Avenue

Suite 200

Fairbanks, AK 99709-3645

(907) 474-7147

Fax: (907) 479-4779

State Oil and Gas Agency

David Johnston, Chairman

Oil and Gas Conservation Commission

3001 Porcupine Drive

Anchorage, AK 99501-3192

(907) 279-1433

Alaska Public Utilities Commission

Robert A. Lohr, Executive Director

1016 West 6th Avenue, Suite 400

Anchorage, AK 99501

(907) 276-6222

Fax: (907) 276-0160 
388 American Samoa

Governor A. P. Lutali

Governor's House

Pago Pago, AS 96799

011 (684) 633-4116

\section{State Energy Office}

Matt Lei, Director

Territorial Energy Office

Office of the Governor

Pago Pago, AS 96799

011 (684) 699-1101

\section{Arizona}

Governor Fife Symington

State Capitol

Phoenix, AZ 85007

(602) 542-4331

State Energy Office

Jack Haenichen, Director

Arizona Energy Office of the Department of

Commerce

3800 North Central Avenue

Suite 1200

Phoenix, AZ 85012

(602) $280-1403$ or $280-1300$

State Geologist

Larry D. Fellows

Arizona Geological Survey

845 N. Park Avenue, Suite 100

Tucson, AZ 85719-4896

(602) 882-4795

FAX: (602) 628-5106

Corporation Commission

James Matthews, Executive Secretary

Arizona Corporation Commission

$1200 \mathrm{~W}$. Washington

Phoenix, AZ 85007

(602) $542-3931$

390 Arkansas

Governor Jim Guy Tucker

250 State Capitol

Little Rock, AR 72201

(501) 682-2345

State Energy Office

Morris Jenkins, Deputy Director

Arkansas Energy Office

No. 1 State Capitol Mall

Little Rock, AR 72201

(501) 682-7315

State Geologist

Norman F. Williams
Arkansas Geological Survey

3815 West Roosevelt Road

Little Rock, AR 72204

(501) 324-9165

State Oil and Gas Agency

William E. Wright, Director

Oil and Gas Commission

P.O. Box 1472

El Dorado, AR 71731-1472

(501) 862-4965

Service Commission

Jerrell Clark, Director

Arkansas Public Service Commission 1000 Center Street

P.O. Box 400

Little Rock, AR 72203-0400

(501) 682-1794

391 California

Governor Pete Wilson

State Capitol

Sacramento, CA 95814

(916) $445-2843$

State Energy Office

Charles R. Imbrecht, Chrirman

California Energy Commission

1516 9th Street

Sacramento, CA 95814

(916) $654-5000$

State Geologist

James F. Davis

California Geological Survey

Department of Conservation

Division of Mines and Geology

$801 \mathrm{~K}$ Street, MS 12-30

Sacramento, CA 95814-3531

(916) 445-1923

Fax: (916) 445-5718

State Oil and Gas Agency

William F. Guerard, Jr.

Acting State Oil and Gas Supervisor

Department of Conservation

Division of Oil, Gas, and Geothermal

Resources

801 K Street, MS 20-20

Sacramento, CA 95814-3500

(916) 445-9686

Public Utilities Commission

Neal J. Shulman, Executive Director 505 Van Ness Avenue, Room $\mathbf{5 2 2 2}$

San Francisco, CA 94102

(415) 703-1487 


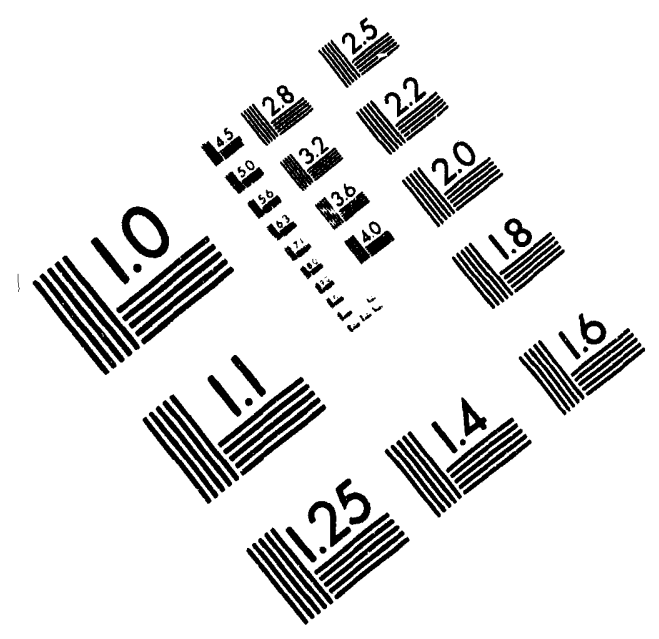

·JNI · $\exists$ כ

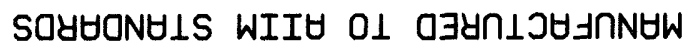
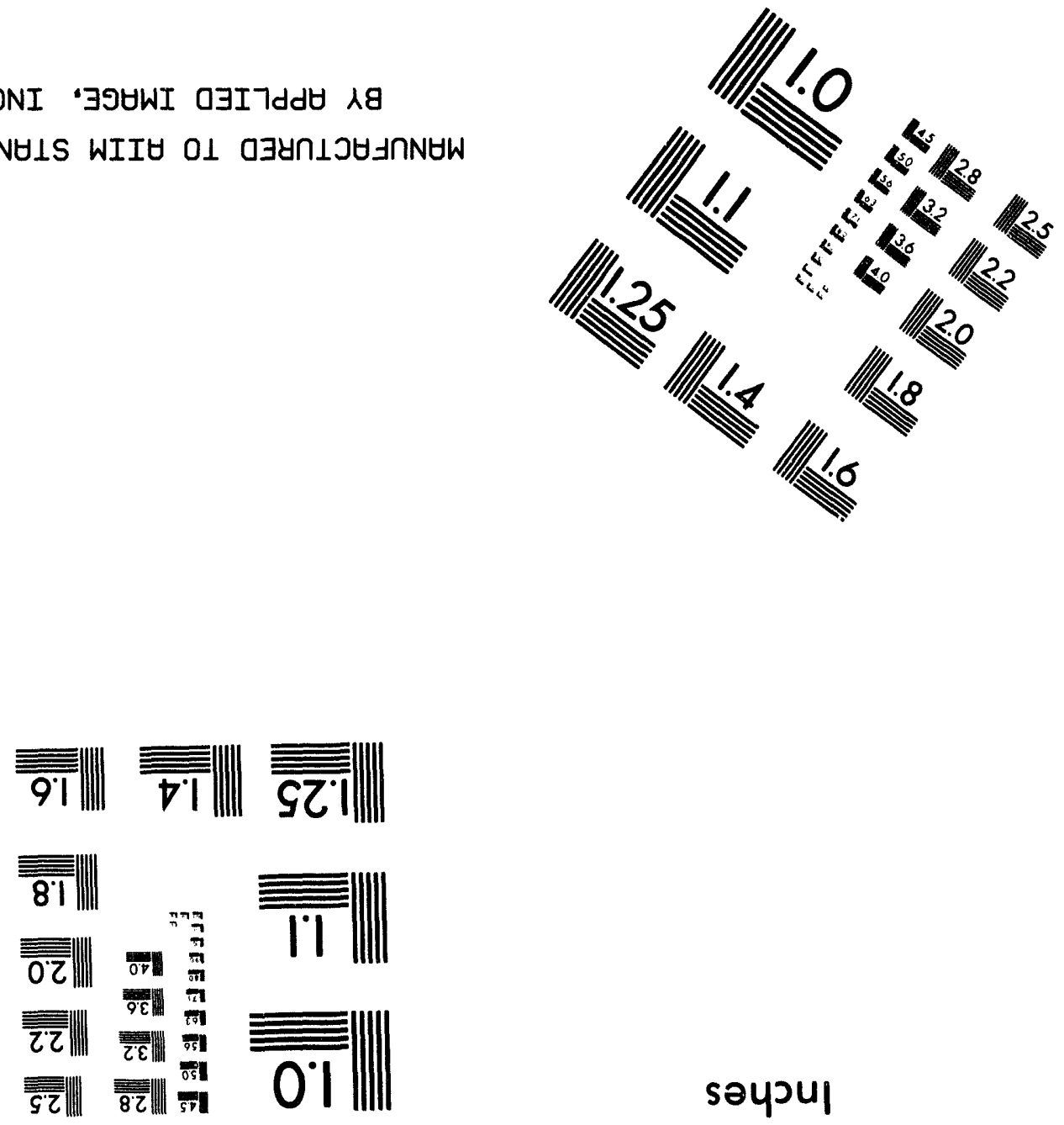

soyวu|
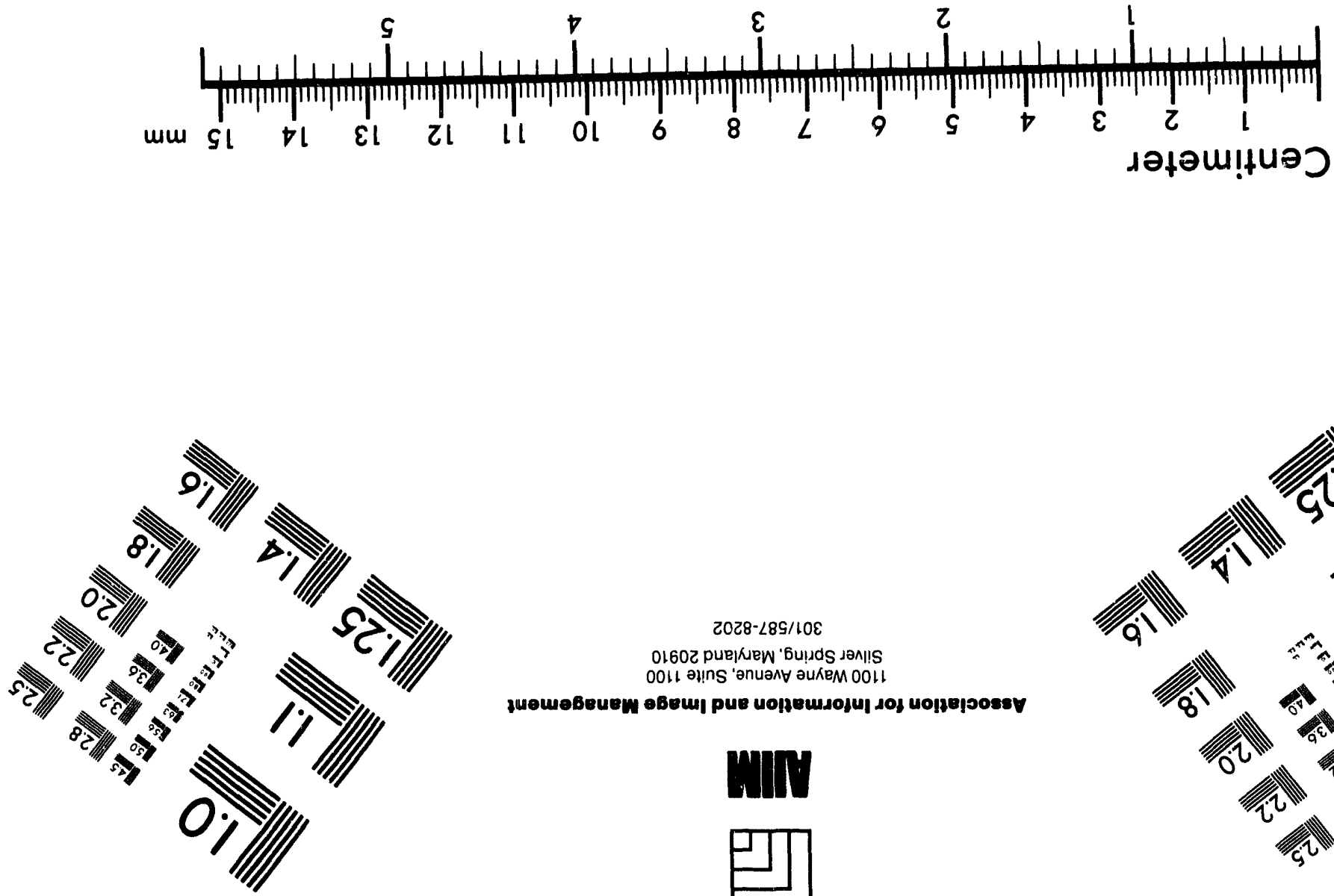

$2028-\angle 8 S / 10 \varepsilon$ OL60Z pue|/NeW ' 6u!ndS Jan!IS

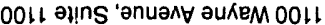

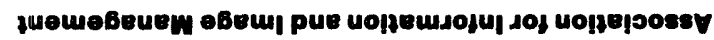
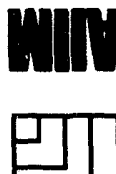

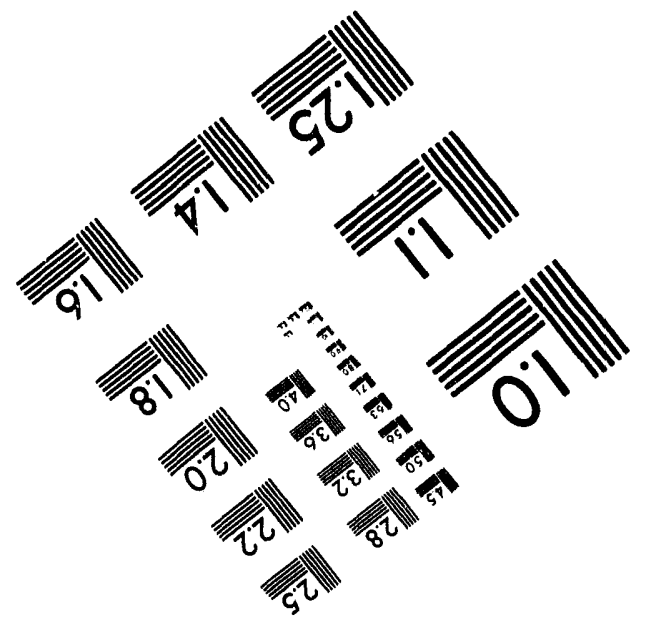



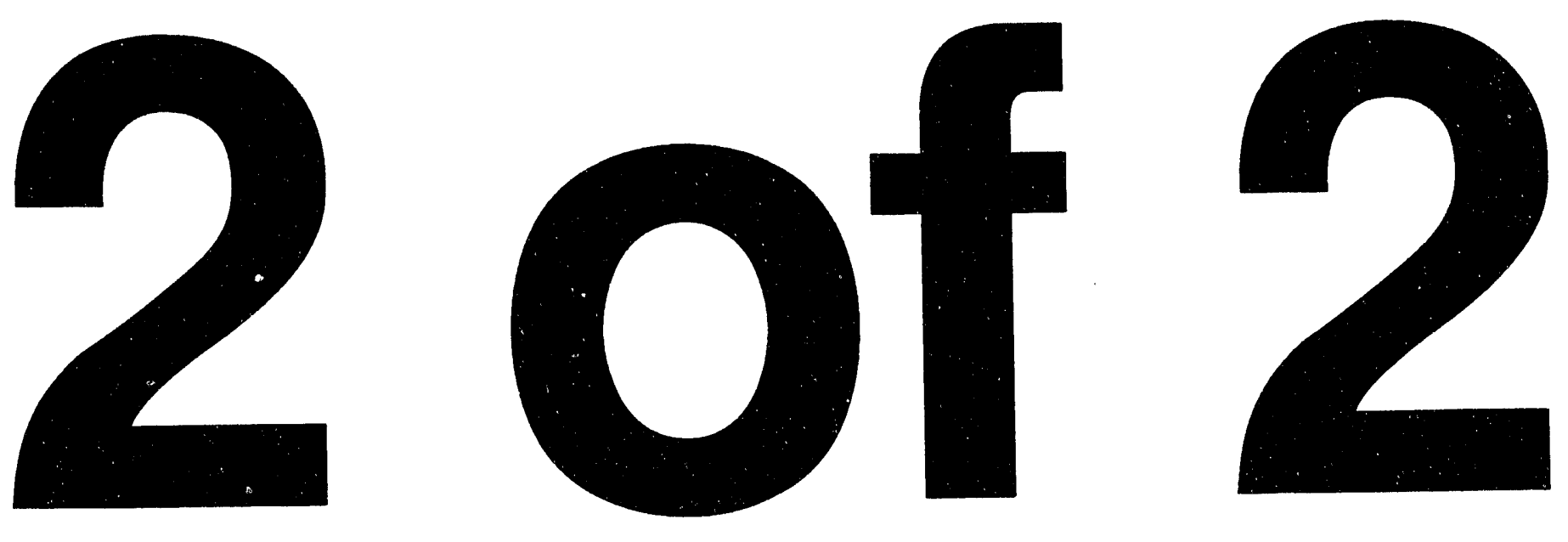
392 Colorado

Governor Roy Romer

State Capitol

Denver, CO 80203

(303) $866-2471$

State Energy Office

Wade Buchanan, Director

Colorado Office of Energy Conservation

1675 Broadway, Suite 1300

Denver, CO 80202-4613

(303) 620-4292

State Geologist

Colorado Geological Survey

1313 Sherman Street, Room 715

Denver, CO 80203

(303) 866-2611

Fax: (303) 866-2115

Oil and Gas Conservation Commission 1580 Logan Street, Suite 380

Denver, CO 80203

(303) 894-2100

Fax: (303) 894-2109

Public Utilities Commission

Ron Lehr, Commissioner

Logan Tower OL2, Logan Street

Denver, CO 80203

(303) 894-2070

\section{Connecticut}

Governor Lowell Weicker

State Capitol

Hartford, CT 06106

(203) $566-4840$

State Energy Office

Susan Shimelman

Office of Policy and Management Policy

Development and Planning Division

80 Washington Street

Hartford, CT 06106

(203) 566-4298

State Geologist

Richard C. Hyde

Connecticut Geological Survey

Department of Environmental Protection

Natural Resources Center

165 Capitol Avenue, Room 553

Hartford, CT 06106

(203) $566-3540$

Department of Public Utility Control

Louis Rickard
Chief of Research and Policy Analysis

1 Central Park Plaza

New Britain, CT 06051

(203) 827-2601

394 Delaware

Governor Thomas Carper

Legislative Hall

Dover, DE 19901

(302) 736-4101

State Energy Office

Charles T. Smisson, Jr.

Energy Program Administrator

Division of Facilities Management

P. O. Box 1401, O'Neill Building

Dover, DE 19903

(302) 739-5261

Fax: (302) 739-6148

State Geologist

Robert R. Jordan

Delaware Geological Survey

University of Delaware

DGS Building

Newark, DE 19716-7501

(302) 831-2833

Fax: (302) 831-3579

Public Service Commission

R. J. Kennedy, III, Executive Director 1560 DuPont Highway, P. O. Box 457

Dover, DE 19903

(302) $739-4247$

395 District of Columbia

Mayor's Office

Mayor Sharon Pratt Kelly

1350 Pennsylvania Avenue, N.W.

Washington, DC 20004

(202) $727-6310$

City Energy Office

Charles J. Clinton

District of Columbia Energy Office

613 G Street, N.W., 5th Floor

Washington, DC 20001

(202) $727-1800$

Public Service Commission

Dr. Phylicia A. Fauntleroy, Ph.D.

Executive Director

450 Fifth Street, N.W., Suite 800

Washington, DC 20001

(202) 626-9176 
396 Florida

Governor Lawton Chiles

The Capitol

Tallahassee, FL 32399-0001

(904) 488-4441

State Energy Office

Jim Tait

Florida Energy Office

Department of Community Affairs

2740 Centerview Drive

Tallahassee, FL 32399-2100

(904) 488-6764

State Geologist

Walter Schmidt

Florida Geological Survey

Gunter Building

903 W. Tennessee Street

Tallahassee, FL 32304-7700

(904) 488-4191

Fax: (904) 488-8086

Public Service Commission

William D. Talbott, Executive Director

101 E. Gaines Street

Tallahassee, FL 32399-0850

(904) 488-7463

397 Georgia

Governor Zell Miller

State Capitol

Atlanta, GA 30334

(404) 656-1776

\section{State Energy Office}

Paul Burks

Office of Energy Resources

254 Washington Street, SW.

Suite 401

Atlanta, GA 30334-8502

(404) 656-5176

Fax: (404) 656-7970

State Geologist

William H. McLemore

Georgia Geological Survey

EP, Natural Resources

Room 400

19 Martin Luther King Jr. Drive, S.W.

Atlanta, GA 30334

(404) 656-3214
Public Service Commission

B. B. Knowles, Director of Utilities

244 Washington Street, S.W.

Atlanta, GA 30334

(404) 656-4501

398 Guam

Governor Joseph Ada

Executive Office

Agana, GU 96910

(671) $472-8931$

State Energy Office

Michael B. Brown, Director

Guam Energy Office

P.O. Box 2950

Agana, GU 96910

(671) 477-0557

Fax: (671) 477-0589

399 Hawaii

Governor John D. Waihee

State Capitol

Honolulu, HI 96813

(808) $548-6420$

State Energy Office

Maurice H. Kaya

Energy Program Administrator

Energy Division

Department of Business, Economic

Development \& Tourism

335 Merchant Street, Room 110

Honolulu, HI 96813

(808) $587-3812$

Fax: (808) 587-3820

State Geologist

Manabu Tagomori

Hawaii Geological Survey

Department of Land

and Natural Resources

Division of Land and Water Development

P. O. Box 373

Honolulu, HI 96809

(808) 548-7533

Fax: (808) 548-6052

Public Utilities Commission

Yukio Naito, Chairman

465 S. King Street, \#103

Honolulu, HI 96813

(808) $586-2020$ 
400 Idaho

Governor Cecil D. Andrus

State Capitol

Boise, ID 83720

(208) $334-2100$

State Energy Office

Robert Hoppie

Idaho Department of Water Resources

Energy Division

1301 North Orchard

Boise, ID 83706

(208) $327-7900$

State Geologist

Earl H. Bennett

Idaho Geological Survey

Room 332, Morrill Hall

University of Idaho

Moscow, ID 83843

(208) 885-7991

Fax: (208) 885-5826

Public Utilities Commission

Stephanie Miller, Administrator

Utilities Division

State House Mail

Boise, ID 83720-6000

(208) 334-0366

401 Illinois

Governor Jim Edgar

State Capitol

Springfield, IL 62706

(217) $782-6830$

State Energy Office

John S. Moore, Director

Department of Energy and Natural

Resources

325 West Adams Street

Room 300

Springfield, IL 62704

(217) 785-2800

State Geologist

Morris W. Leighton

Illinois Geological Survey

121 Natural Resources Building

615 East Peabody Drive

Champaign, IL 61820

(217) 333-5111

FAX: (217) 244-7004

State Oil and Gas Agency

Lawrence E. Bengal

Division Supervisor

Illinois Department of Mines and Minerals

Oil and Gas Division

$300 \mathrm{~W}$. Jefferson, Suite 300
P.O. Box 10140

Springfield, IL 62791-0140

(217) 782-7756

Commerce Commission

Donna M. Caton, Chief Clerk

527 E. Capitol Avenue, Box 19280

Springfield, IL 62794-9280

(217) 782-7434

402 Indiana

Governor Evan Bayh

State Capitol

Indianapolis, IN 46204

(317) 232-4567

State Energy Office

Amy Stewart, Director

Department of Commerce

Office of Energy Policy

1 North Capitol, Suite 700

Indianapolis, IN 46204-2288

(317) $232-8940$

State Geologist

Norman C. Hester

Indiana Geological Survey

611 N. Walnut Grove

Bloomington, IN 47405

(812) $855-9350$

Fax: (812) $855-2862$

State Oil and Gas Agency

James A. Slutz, Director

Department of Natural Resources

Oil and Gas Division

402 W. Washington Street, Room 293

Indianapolis, IN 46204

(317) 232-4055

Utility Regulatory Commission

Ruth Ann Townsend, Secretary

302 West Washington Street, Suite E-306

Indianapolis, IN 46204

(317) 232-2701

403 Iowa

Governor Terry E. Branstad

State Capitol

Des Moines, IA 50319

(515) 281-5211

State Energy Office

Larry Bean

lowa Department of Natural Resources

Energy and Geological Resources Division

Wallace State Office Building

Des Moines, IA 50319

(515) 281-6682 
State Geologist

Donald L. Koch

Department of Natural Resources

Geological Survey Bureau

109 Trowbridge Hall

Iowa City, IA 52242-1319

(319) 335-1575

Fax: (319) 335-2754

State Oil and Gas Agency

Donald L. Koch

State Geologist

Geological Survey Bureau

109 Trowbridge Hall

Iowa City, IA 52242-1319

(319) 335-1575

Fax: (319) 335-2754

Iowa Utilities Board

Raymond K. Vawter, Executive Secretary

Lucas State Office Building

Des Moines, IA 50319

(515) 281-5256

404 Kansas

Governor Joan Finney

State House

Topeka, KS 66612

(913) 296-3232

State Energy Office

Bill Ayesh

Energy Program Supervisor Energy Division

1500 S.W. Arrowhead Road

Topeka, KS 66604

(913) 271-3260

(316) 263-3238 (in Wichita, KS)

State Geologist

Lee C. Gerhard

Kansas Geological Survey

1930 Constant Avenue, West Campus

The University of Kansas

Lawrence, KS 66047

(913) 864-3965

State Oil and Gas Agency

William R. Bryson, Director

Oil and Gas Conservation Division

Corporation Commission

200 Colorado Derby Building

Wichita, KS 67202

(316) 263-3238

Corporation Commission

Judith McConnel

Kansas Corporation Commission

1500 S.W. Arrowhead Road

Topeka, KS 66604

(913) 271-3170
405 Kentucky

Governor Brereton C. Jones

State Capitol

Frankfort, KY 40601

(502) $564-2611$

State Energy Office

William Bowker

Kentucky Coal Marketing and Export

Council Cabinet for Economic Development

Capital Plaza Tower

Frankfort, KY 40601

(502) $564-7140$

State Geologist

Donald C. Haney

Kentucky Geological Survey

228 Mining and Mineral Resources Building

University of Kentucky

Lexington, KY 40506-0107

(606) 257-5500

State Oil and Gas Agency

D. Michael Wallen, Director

Department of Mines and Minerals

Oil and Gas Division

Box 14080

Lexington, KY 40512

(606) 254-0367

Public Service Commission

Uonald C. Mills

Executive Director

730 Schenkel Lane, Box 615

Frankfort, KY 40602

(502) $564-3940$

406 Louisiana

Governor Edwin W. Edwards

State Capitol

P. O. Box 94004

Baton Rouge, LA 70804

(504) 342-7015

State Energy Office

Robert Harper

Louisiana Department of Natural Resources

P. O. Box 94396

Baton Rouge, LA 70804-9396

(504) 342-4534

State Geologist

William E. Marsalis

Louisiana Geological Survey

P. O. Box G

University Station

Baton Rouge, LA 70893

(504) 388-5320

Fax: (504) 388-5328 
State Oil and Gas Agency

Herbert M. Thompson, Commissioner

Office of Conservation

Box 94275

Baton Rouge, LA 70804-9275

(504) $342-5500$

Public Service Commission Marshall B. Brinkley, Secretary

Suite 1630, One American Place

Baton Rouge, LA 70825

(504) 342-4404

Mail letters to: P. O. Box 91154

Baton Rouge, LA 70821-9154

407 Maine

Governor John R. McKernan, Jr.

State House

Augusta, ME 04333

(207) 289-3531

State Energy Office

Michael H. Draper, Program Manager

Energy Conservation Division

Department of Economic and

Community Development

State House, Station \#130

Augusta, ME 04333

(207) 624-6838

Fax: (207) 624-6810

State Geologist

Walter A. Anderson

Maine Geological Survey

Department of Conservation

State House Station \#22

Augusta, ME 04333

(207) 289-2801

Fax: (207) 289-2353

Public Utilities Commission

Charles A. Jacobs, Administrative Director

State House, Station 18

Augusta, ME 04333

(207) 287-3831

\section{Maryland}

Governor William Donald Schaefer

State House

Annapolis, MD 21404

(301) 974-3901

State Energy Office

Gerald L. Thorpe, Director

Maryland Energy Administration

45 Calvert Street, 4th Floor

Annapolis, MD 21401

(410) 974-3751
State Geologist

Emery T. Cleaves

Maryland Geological Survey

2300 St. Paul Street

Baltimore, MD 21218-5210

(410) $554-5500$

Fax: (410) 554-5502

State Oil and Gas Regulations/Permitting

Agency

Ed Larrimore

Minerals, Oil \& Gas Division

Department of Natural Resources

580 Taylor Avenue

Annapolis, MD 21401

(410) 974-3874

Fax: (410) 974-2618

State Oil and Gas Resources Agency

Kenneth A. Schwartz

Maryland Geological Survey

2300 St. Paul Street

Baltimore, MD 21218-5210

(410) 554-5525

Fax: (410) 554-5502

Public Service Commission

Ronald E. Hawkins

American Building

231 E. Baltimore Street

Baltimore, MD 21202

(410) 333-6066

409 Massachusetts

Governor William Weld

State House

Boston, MA 02133

(617) $727-3600$

State Energy Office

Stephen Remen, Commissioner

Massachusetts Executive Office

of Energy Resources

Leverett Saltonstall Building

100 Cambridge Street, Room 1500

Boston, MA 02202

(617) 727-4732

State Geologist

Richard N. Foster

Massachusetts Geological Survey

Commonwealth of Massachusetts

Executive Environmental Affairs

100 Cambridge Street, 20th Floor

Boston, MA 02202

(617) 727-5830, Ext. 305

Fax: (617) 727-2754 
Department of Public Utilities

Robert D. Shapiro, General Counsel

100 Cambridge Street, 12th Floor

Boston, MA 02202

(617) $727-3500$

410 Michigan

Governor John Engler

State Capitol

Lansing, MI 48909

(517) 373-3400

State Energy Office

Jan Patrick, Conservation Section Supervisor

Energy Resources Division

Michigan Public Service Commission

P. O. Box 30221

6545 Mercantile Way

Lansing, MI 48909

(517) $334-6270$

State Geologist

R. Thomas Segall

Michigan Geological Survey

Department of Natural Resources

Geological Survey Division

Box 30028

Lansing, MI 48909

(517) 334-6923

Fax: (517) 334-6038

\section{State Oil and Gas Agency}

Ronald O. Skoog, Director and Supervisory

of Wells

Department of Natural Resources

Box 30028

Lansing, MI 48909

(517) 373-2329

Public Service Commission

Steven Fetter, Chairman

Michigan Public Service Commission

P. O. Box 30221

6545 Mercantile Way

Lansing, MI 48909

(517) $334-6370$

\section{Minnesota}

Governor Arne Carlson

State Capitol

St. Paul, MN 55155

(612) 296-3391

State Energy Office

Krista L. Sanda, Commissioner

Department of Public Service

121 7th Place East, Suite 200

St. Paul, MN 55101-2145

(612) 296-7107

Fax: (617) 297-1959
State Geologist

Priscilla C. Grew

Minnesota Geological Survey

University of Minnesota

2642 University Avenue

St. Paul, MN 55114-1057

(612) 627-4780

Fax: (612) 627-4778

Public Utilities Commission

Rick Lancaster, Executive Secretary

121 Seventh Place East, Suite 350

St. Paul, MN 55101-2147

(612) 296-7124

412 Mississippi

Governor Kirk Fordice

State Capitol

Jackson, MS 39201

(601) $359-3100$

State Energy Office

Chester Smith, Director

Energy Division

510 George Street

Jackson, MS 39202-3096

(601) $359-6600$

State Geologist

S. Cragin Knox

Mississippi Geological Survey

Department of Environmental Quality

P. O. Box 5348

Jackson, MS 39296-5348

(601) 354-6228

Fax: (601) 354-6327

State Oil and Gas Agency

A. Richard Henderson, Supervisor

State Oil and Gas Board

500 Greymont, Suite E

Jackson, MS 39202

(601) 354-7142

Public Service Commission

William A. Wilkerson

Executive Director

Room 1738, Walter Sillers State

Office Building

P. O. Box 1174

Jackson, MS 39215-1174

(601) $961-5493$

413 Missouri

Governor Mel Carnahan

State Capitol

Jefferson City, MO 65102

(314) 751-3222 
State Energy Office

Division of Energy

Missouri Department of Natural Resources

P. O. Box 176

Jefferson City, MO 65102

(314) $751-4000$

State Geologist

James H. Williams

Missouri Geological Survey

Department of Natural Resources

Division of Geology and Land Survey

P.O. Box 250

Rolla, MO 65401

(314) 368-2101

\section{State Oil and Gas Agency}

James H. Williams, Acting Administrator,

Acting Director and State Geologist

Division of Geology and Land Survey

State Oil and Gas Council

Box 250

Rolla, MO 65401

(314) 364-1752

Public Service Commission

Brent Stewart

Executive Secretary

P. O. Box 360

Jefferson City, MO 65102

(314) 751-5246

\section{Montana}

Governor Marc Racicot

State Capitol

Helena, MT 59620

(406) 444-3111

State Energy Office

Van Jamison, Administrator

Energy Division

Department of Natural Resources

and Conservation

1520 East Sixth Avenue

Helena, MT 59620-2301

(406) 444-6812

\section{State Geologist}

Edward T. Ruppel

Montana Bureau of Mines and Geology

West Park Street

Montana Tech

Main Hall

Butte, MT 59701

(406) 496-4180

Fax: (406) 496-4451

Oil and Gas Agency

Thomas P. Richmond
Administrator-Petroleum Engineer

Board of Oil and Gas Conservation

2535 St. John's Avenue

Billings, MT 59102

(406) 656-0040

Public Service Commission

Kathy Anderson, Commission Secretary

1701 Prospect Avenue

Helena, MT 59620

(406) 444-6170

Fax: (406) 444-7618

415 Nebraska

Governor E. Benjamin Nelson

State Capitol

Lincoln, NE 68509

(402) 471-2244

State Energy Office

Robert Harris, Director

Nebraska Energy Office

The Atrium, 1st Floor

1200 N Street, Suite 110

Lincoln, NE 68509

(402) 471-2867

State Geologist

Perry B. Wigley

Nebraska Geological Survey

Conservation and Survey Division

Institute of Agriculture and Natural

Resources

University of Nebraska

113 Nebraska Hall

901 N. 17th Street

Lincoln, NE 68588-0517

(402) $472-3471$

Fax: (402) $472-2410$

State Oil and Gas Agency

Paul H. Roberts, Director

Oil and Gas Conservation Commission

Box 399

Sidney, NE 69162

(308) 254-4595

Fax: (308) 245-7022

Public Service Commission

M. G. Hand, Chief Engineer

300 The Atrium

1200 N Street, P. O. Box 94927 )

Lincoln, NE 68509-4927

(402) 471-3101

\section{Nevada}

Governor Bob Miller

State Capitol

Carson City, NV 89710

(702) 687-5670 
State Energy Office

Jim Hawke, Director

Nevada Office of Community Services

Capitol Complex

Carson City, NV 89710

(702) $687-4990$

Fax: (702) 687-4914

State Geologist

Harold F. Bonham, Jr.

Nevada Bureau of Mines and Geology

University of Nevada

Reno, NV 89557-0088

(702) 784-6691

Fax: (702) 784-1709

State Oil and Gas Agency

Russ Fields, Director

Department of Minerals

400 W. King Street

Capitol Complex

Carson City, NV 89710

(702) 885-5050

Public Service Commission

William H. Vance, Secretary

727 Fairview Drive

Carson City, NV 89710

(702) 687-6001

417 New Hampshire

Governor Stephen Merrill

State House

Concord, NH 03301

(603) 271-2121

State Energy Office

Jonathan Osgood, Director

Governor's Office of Energy

and Community Service

57 Regional Drive

Concord, NH 03301

(603) 271-2711

\section{State Geologist}

Eugene L. Bor'dette

New Hampshire Geological Survey

Department of Environmental Services

P.O. Box 2008

Concord, NH 03302-2008

(603) 271-3406

Fax: (603) 271-1381

Public Utilities Commission

Wynn E. Arnold, Secretary and Executive

Director

8 Old Suncook Road

Concord, NH 03301-5185

(603) 271-2431

Fax: (603) 271-3878
418 New Jersey

Governor Christine T. Whitman

State House

Trenton, NJ 08625

(609) 292-6000

State Energy Office

Scott Weiner, Commissioner

Department of Environmental Protection

and Energy

Office of Energy

401 East State Street

Trenton, NJ 08625

(609) 292-2885

Nancy Wittenberg, Director

New Jersey Department of Environmental Protection and Energy

P.O. Box CN 402

Trenton, NJ 08625

(609) 292-5383

State Geologist

Haig F. Kasabach

New Jersey Geological Survey

Department of Environmental Protection

and Energy

P. O. Box CN-427

Trenton, NJ 08625

(609) 292-1185

Fax: (609) 633-1004

Board of Regional Commissioners

Sharon Schulman, Chief Executive Officer

2 Gateway Center

Newark, NJ 07102

(201) 648-2370

419 New Mexico

Governor Bruce King

TERA Building, Room 542

Santa Fe, NM 87503

(505) $827-3000$

State Energy Office

Dianne Caron, Director

Energy Conservation \& Management

Division

Energy, Minerals \& Natural Resources De

partment

2040 South Pacheco

Santa Fe, NM 87505

(505) 827-5900

State Geologist

Charles E. Chapin

New Mexico Bureau of Mines Minerals Resources

Campus Station

Socorro, NM 87801 
(505) $835-5420$

Fax: (505) 835-6333

State Oil and Gas Agency

William J. LeMay, Director

Energy, Minerals and Natural Resources

Department

Oil and Conversation Division, Box 2088

Santa Fe, NM 87501

(505) $827-5800$

Public Service Commission

Bill R. Garcia, Executive Director

224 E. Palace

Santa Fe, NM 87501-2013

(505) $827-6940$

420 New York

Governor Mario M. Cuomo

Executive Chamber

State Capitol

Albany, NY 12224

(518) $474-8390$

State Energy Office

Francis J. Murray, Jr., Commissioner

New York State Energy Office

2 Rockefeller Plaza

Albany, NY 12223

(518) $473-4376$

State Geologist

Robert H. Fakundiny

New York Geological Survey

State Museum

Empire State Plaza

3136 Cultural Education Center

Albany, NY 12230

(518) 474-5816

Fax: (518) 473-8496

State Oil and Gas Agency

Gregory H. Sovas, Director

Department of Environmental Conservation

Division of Mineral Resources

50 Wolf Road, Room 202

Albany, NY 12233

(518) 457-9337

Public Service Commission

John J. Kelliher, Secretary

3 Empire State Plaza

Albany, NY 12223

(518) 474-6530

421 North Carolina

Governor James B. Hunt, Jr.

State Capitol

Raleigh, NC 27611

(919) 733-5811
State Energy Office

Carson D. Culbreth

North Carolina Department of Commerce

Energy Division

430 North Salisbury Street

P. O. Box 25249

Raleigh, NC 27611

(919) 733-2230

State Geologist

Charles H. Gardner

North Carolina Geological Survey

Department of Environment, Health, and

Natural Resources

Division of Land Resources

P. O. Box 27687

Raleigh, NC 27611-7687

(919) 733-3833

Fax: (919) 733-4407, (919) 733-2876

State Oil and Gas Agency

Charles H. Gardner, Director

Department of Environment, Health, and

Natural Resources

Division of Land Resources

512 N. Salisbury St., Box 27887

Raleigh, NC 27611

(919) 733-3833

Public Utilities Commission

Robert P. Gruber, Executive Director

Public Staff, P. O. Box 29520

Raleigh, NC 27626-0520

(919) 733-2435

422 North Dakota

Governor Ed Schafer

State Capitol

Bismarck, ND 58505

(701) 224-2200

State Energy Office

Kim Christianson

Energy Program Manager

Office of Intergovernmental Assistance

State Capitol Building

600 E. Boulevard Avenue, 14th Floor

Bismarck, ND j8505-0170

(701) 224-2094

State Geologist

John P. Bluemle

North Dakota Geological Survey

600 East Boulevard

Bismarck, ND 58505-0840

(701) 224-4109

Fax: (701) 224-3682 
State Oil and Gas Agency

Wesley D. Norton, Director

Industrial Commission

Oil and Gas Division

600 East Boulevard

Bismarck, ND 58505-0840

(701) 224-3682

Fax: (701) 224-3582

Public Service Commission

Janet Elkin, Secretary

State Capitol

Bismarck, ND 58505

(701) 224-2400

\section{Ohio}

Governor George Voinovich

State House

Columbus, $\mathrm{OH} 43215$

(614) 466-3555

State Energy Office

Donald Jakeway, Director

Ohio Department of Development

Community Development Division

Office of Energy Efficiency

77 S. High Street, 26th Floor

Columbus, $\mathrm{OH} 43266-0413$

(614) 466-6797

State Geologist

Thomas M. Berg

Division of Geological Survey

Ohio Department of Natural Resources

4383 Fountain Square Drive, Building B

Columbus, $\mathrm{OH} 43224$

(614) 265-6576

Fax: (614) 447-1918

State Oil and Gas Agency

Renee Houser, Chief

Department of Natural Resources

Division of Oil and Gas

Fountain Square A-3

Columbus, $\mathrm{OH} 43224$

(514) 265-6917

Public Utilities Commission

Gary Vigorito, Director

Administration and Commission Secretary

180 E. Broad Street

Columbus, $\mathrm{OH}$ 43266-0573

(614) 466-3016

424 Oklahoma

Governor David Walters

State Capitol

Oklahoma City, OK 73105

(405) 521-2342
Secretary of Energy

The Honorable Charles Nesbitt

125 N.W. Sixth Street

Oklahoma City, OK 73105

(405) 235-4204

State Alternative Fuels Office

Jason N. Smitherman, Administrator

Alternative Fuels Program

Department of Central Services

3301 North Santa Fe

Oklahoma City, OK 73118

(405) 521-4687

State Energy Office

Sherwood Washington

Oklahoma Department of Commerce

Division of Community Affairs and

Development

P.O. Box 26980

Oklahoma City, OK 73126-0980

(405) 841-9326

State Geologist

Charles J. Mankin

Oklahoma Geological Survey

100 East Boyd, Room N-131

Norman, OK 73019-0628

(405) 325-3031

Fax: (405) 325-7069

State Oil and Gas Agency

Charles D. Davidson, Director

Oil and Gas Conservation Division

Corporation Commission

Jim Thorpe Building

Oklahoma City, OK 73105

(405) 521-2303

Corporation Commission

Larry Schroeder, Director

Public Utility Division

500 Jim Thorpe Office Building

Oklahoma City, OK 73105

(405) 521-3908

425 Oregon

Governor Barbara Roberts

State Capitol

Salem, OR 97310

(503) $378-3100$

State Energy Office

Christine Ervin, Director

Oregon Department of Energy

625 Marion Street NE

Salem, OR 97310-0831

(503) $378-4040$ 
State Geologist and Director

Donald A. Hull

Oregon Department of Geology and

Mineral Industries

800 NE Oregon Street, \#28, Room 965

Portland, OR 97232

(503) $731-4600$

Fax: (503) 731-4066

Public Utility Commission

Ron Eachus, Commission Chairman

550 Capitol Street, N.E.

Salem, OR 97310-1380

(503) 378-6611

426 Pennsylvania

Governor Robert Casey

State Capitol

Harrisburg, PA 17120

(717) 787-2500

State Energy Office

Brian Castelli

Executive Director

Pennsylvania Energy Office

116 Pine Street

Harrisburg, PA 17101

(717) 783-9981

\section{State Geologist}

Donald M. Hoskins

Pennsylvania Geological Survey

Bureau of Topographic and Geologic Survey

Department of Environmental Resources

P.O. Box 8453

Harrisburg, PA 17105-8453

(717) 787-2169

Fax: (717) 783-7267

State Oil and Gas Agency

James E. Erb, Director

Department of Environmental Resources

Bureau of Oil and Gas Management

Box 2357

Harrisburg, PA 17120

(717) 783-9645

Public Utility Commission

John L. Dial, Executive Director

P. O. Box 3265

Harrisburg, PA 17120

(717) $783-1740$

\section{Puerto Rico}

Governor

Pedro J. Rossello

P.O. Box 1992

Fernandez Juncos Station

San Juan, PR 00901

(809) 721-1992
State Energy Office

Ivan Ayala Cadiz

Energy Affairs

Department of Consumer Affairs

P.O. Box 41.059

Santurce, PR 00940

(809) 721-0940

428 Rhode Island

Governor Bruce Sundlun

State House

Providence, RI 02903

(401) 277-2080

State Energy Office

Scott Wolf, Director

Governor's Office of Housing, Energy, and Intergovernmental Relations

275 Westminister Street

Providence, RI 02903

(401) 277-3370

State Geologist

J. Allan Cain

Office of the Rhode Island State Geologist

Department of Geology

University of Rhode Island

315 Green Hall

Kingston, RI 02881

(401) 792-2265

Fax: (401) 792-2190

Public Utility Commission

Edward F. Burke, Administrator

100 Orange Street

Providence, RI 02903

(401) 783-1740

429 South Carolina

Governor Carroll A. Campbell, Jr.

State House

Columbia, SC 29211

(803) 758-3208

\section{State Energy Office}

Nancy Rwen

Governor's Division of Energy,

Agriculture and Natural Resources

1205 Pendleton Street

Columbia, SC 29209

(803) 734-0329

State Geologist

Alan-Jon W. Zupan, Acting State Geologist

South Carolina Geological Survey

5 Gcology Road

Columbus, SC 29210-9998

(803) 737-9440

Fax: (803) 737-9487 
State Oil and Gas Agency

Alfred H. Vang, Executive Director

Water Resources Commission

1201 Main Street, Suite 100

Columbia, SC 29201

(803) 737-0800

\section{Public Service Commission}

R. L. Smith, Director

Utility Division

P. O. Box 11649

Columbia, SC 29211

(803) $737-5125$

\section{South Dakota}

Governor Walter D. Miller

State Capitol

Pierre, SD 57501

(605) 773-3212

State Energy Office

Governor's Office of Energy Policy

217 West Missouri, Suite 200

Pierre, SD 57501-4516

(605) 773-3603

Fax: $605-773-4802$

State Geologist

Cleo Christensen

South Dakota Geological Survey

Department of Environment and Natural

Resources

University of South Dakota Science Center

Vermillion, SD 57069-2390

(605) 677-5227

Fax: (605) 677-5895

State Oil and Gas Agency

Robert E. Roberts, Secretary

Department of Environment and Natural

Resources

523 E. Capitol

Pierre, SD 57501

(605) 773-5559

Public Utilities Commission Marshall Damgarrd, Executive Director 500 East Capitol

Pierre, SD 57501

(605) 773-3201

\section{Tennessee}

Governor Neal Ray McWherter

State Capitol

Nashville, TN 37219

(615) 741-2001

State Energy Office

Cynthia Oliphant, Director
Tennessee Department of Economic and Community Development

Energy Division

320 6th Avenue North, 6th Floor

Nashville, TN 37243-0405

(615) 741-2994

Fax: (615) 741-5070

State Geologist

Edward T. Luthıer

Tennessee Geological Survey

Department of Environment and

Conservation

Division of Geology

L\&C Tower, 13th Floor

401 Church Street

Nashville, TN 37243-0445

(615) $532-1500$

Fax: (615) 532-0231

State Oil and Gas Agency

Michael L. Hoyal, Geologist 4

State oil and Gas Board

Division of Water Supply

L\&C Tower, 6th Floor

401 Church Street

Nashville, TN 37243-0445

(615) 532-0171

Public Service Commission

Paul Allen, Executive Director

460 James Robertson Parkway

Nashville, TN 37243-0505

(615) 741-2904

432 Texas

Governor Ann Richards

State Capitol

Austin, TX 78711

(512) $463-2000$

State Energy Management Center Harrison Worcester

Governor's Energy Office

201 East 14th Street

Sam Houston Building

Austin, TX 78701

(512) 463-1961

State Geologist

William L. Fisher

Texas Geological Survey

Bureau of Economic Geology

The University of Texas at Austin

Box $X$, University Station

Austin, TX 78713-7508

(512) 471-7721

Fax: (512) 471-0140 
State Oil and Gas Agency

Jim H. Morrow, Director

Oil and Gas Division

Railroad Commission

Box 12967, Capital Station

Austin, TX 78711-2967

(512) 463-6893

Public Utility Commission

William Dunn

Public Information Officer

7800 Shoal Creek Boulevard

Austin, TX 78757

(512) 458-0256

\section{Utah}

Governor Mike Leavitt

State Capitol

Salt Lake City, UT 84114

(801) 538-1000

State Energy Office

Richard M. Anderson

Utah Division of Energy

355 West North Temple

3 Triad Center, Suite 450

Salt Lake City, UT 84180-1204

(801) 538-5428

\section{State Geologist}

M. Lee Allison

Utah Geological Survey

2363 South Foothill Drive

Salt Lake City, UT 84109-1491

(801) 467-7970

Fax: (801) 467-4070

State Oil and Gas Agency

James W. Carter, Director

Division of Oil, Gas and Mining

3 Triad Center, Suite 350

355 West North Temple

Salt Lake City, UT 84180-1203

(801) 538-5340

Public Service Commission

Julie Orchard, Commission Secretary

160 East 300 South

Box 45585

Salt Lake City, UT 84145

(801) $530-6716$

\section{Vermont}

Governor Howard Dean

State House

109 State Street

Montpelier, VT 05602

(802) 828-3333
Department of Public Services

Scudder Parker, Director

Energy Efficiency Division

120 State Street

Montpelier, VT 05620

(802) 828-2393

Public Service Board

Susan M. Hudson, Clerk

89 Main Street

City Center Building, 3rd Floor

Drawer 20

Montpelier, VT 05620-2701

(802) 828-2358

State Geologist

Diane L. Conrad

Agency of Natural Resources

Vermont Geological Survey

103 South Main Street, Center Building

Waterbury, VT 05671-0301

(802) 244-5164

Fax: (802) 244-1102

435 Virginia

Governor George F. Allen

State Capitol

P. O. Box 1477

Richmond, VA 23219

(804) 786-2211

State Energy Office

James A. Smith, Director

Division of Energy

Department of Mines, Minerals and Energy

2201 West Broad Street

Richmond, VA 23220

(804) 367-6851

State Geologist

Stanley S. Johnson

Virginia Geological Survey

DMME, Division of Mineral Resources

Natural Resources Building

McCormick Road, P. O. Box 3667

Charlottesville, VA 22903

(804) 293-5121

Fax: (804) 293-2239

State Oil and Gas Agency

Byron T. Fulmer

Director, Division of Gas \& Oil

Department of Mines, Minerals and Energy

230 Charwood Drive

P.O. Box 1416

Abingdon, VA 24210

(703) 676-5423 
State Corporation Commission William Bridge, Director Jefferson Building, Box 1197

Richmond, VA 23209

(804) 786-3733

436 Virgin Islands

Governor Alexander A. Farrelly

Governor's House

Charlotte Amalie

St. Thomas, VI 00802

(809) 774-00101

Energy Office

Claudette Young-Hinds

Virgin Islands Energy Office

Christiansted

St. Croix, VI 00820

(809) 772-2616

Fax: (809) 772-0063

437 Washington

Governor Mike Lowry

State Capitol

Legislative Building

Olympia, WA 98504

(206) 753-6780

State Energy Office

Jim Harding, Acting Director

Washington State Energy Office

925 Plum Street, SE, P.O. Box 43165

Olympia, WA 98504-3165

(206) 956-2000

State Geologist

Raymond Lasmanis

Washington Geological Survey

Department of Natural Resources, Geology

and Earth Resources Division

Mail Stop PY-12

4224 Sixth Avenue, SE

Building 1, Row 6

Olympia, WA 98504

(206) 459-6372

Fax: (206) 459-6380

State Oil and Gas Agency

Raymond Lasmanis

Oil and Gas Supervisor

Department of Natural Resources

Division of Geology and Earth Resources

Olympia, WA 98504

(206) 459-6372

Utilities and Transportation Commission

Paul Curl, Administrative Manager

Chandler Plaza Building South

1300 Evergreen Park Drive, SW

P.O. Box 9022
Olympia, WA 98504-9022

(206) 753-6423

438 West Virginia

Governor Gaston Caperton

State Capitol Complex

Charleston, WV 25305

(304) 348-2000

State Energy Office

John F. (Jeff) Herholdt, Jr.

West Virginia Development Office

Fuel and Energy Division

Building 6, 553 Capital Complex

Charleston, WV 25305

(304) 558-4010

Fax: (304) 558-3248

State Geologist

Larry D. Woodfork

West Virginia Geological Survey

Mont Chateau Research Center

P.O. Box 879

Morgantown, WV 26507-0879

(304) 594-2331

Fax: (304) 594-2575

State Oil and Gas Conservation

Commission

Thomas M. Streit, Acting Commissioner

Oil and Gas Conservation Commission

10 McJunkin Road

Nitro, WV 25143-2506

(304) $759-0516$

Public Service Commission

H. M. Cunningham

201 Brooks Street (Street Address)

P. O. Box 812 (Mailing Address)

Charleston, WV 25323

(304) $340-0426$

439 Wisconsin

Governor Tommy G. Thompson

State Capitol

P.O. Box 7863

Madison, WI 53707

(608) 266-1212

Fax: (608) 267-8983

State Energy Office

Nathaniel E. Robinson, Administrator

Wisconsin Division of Energy and

Intergovernmental Relations

101 East Wilson Street, 6th Floor

P. O. Box 7868

Madison, WI 53707-7868

(608) 266-8234

Fax: (608) 267-0200 
State Geologist

James M. Robertson

Wisconsin Geological Survey

3817 Mineral Point Road

Madison, WI 53705-5100

(608) 262-1705

Fax: (608) 262-8086

Public Service Commission

Jeffrey L. Butson

Public Affairs Director

4802 Sheboygan Avenue

Madison, WI 53707

(608) 266-9600

Fax: (608) 266-3957

Mail letters to: P.O. Box 7854

Madison, WI 53707

\section{Wyoming}

Governor Michael Sullivan

State Capitol Building, Room 124

Cheyenne, WY 82002

(307) 777-7437

\section{State Energy Office}

George Gault

Wyoming Department of Commerce

Division of Economic \& Community

Development
Barrett Building

4th Floor North

Cheyenne, WY 82002

(307) 777-7284

State Geologist

Gary B. Glass

Geological Survey of Wyoming

Box 3008

University Station

Laramie, WY 82071-3008

(307) 766-2286

Fax: (307) 766-2605

Wyoming Oil and Gas Conservation

Commission

Donald B. Basko, Oil and Gas Supervisor

Box 2640

Casper, WY 82602

(307) 234-7147

Fax: (307) 234-5306

Public Service Commission

A. J. Eliopulos, Chief Counsel and Administrative Secretary

700 W. 21st Street

Cheyenne, WY 82002

(307) 777-7427 


\section{Trade Associations}

\section{Air Conditioning Contractors of America 151316 th Street, N.W. Washington, DC 20036 (202) 483-9370}

Heating and ventilation contractors who need technical information on energy conservation, building load calculations, or heat pump applications can contact this organization. A catalogue listing technical publications and business management aids is available. $A$ free newsletter, "Air Conditioning Contractors of American News," is published monthly for members only.

\section{Air Transport Association of America (ATA) \\ Robert J. Aaronson, President 1301 Pennsylvania Avenue, N.W., Suite 1100 Washington, DC 20006-1707 (202) 626-4000}

Responsible for airlines engaged in transporting persons, goods, and mail by aircraft between fixed terminals on regular schedules. Maintains resource library of transportation texts and congressional, administrative, and legal histories of civil aviation.

\section{Aircraft Owners and Pilots Association (AOPA) \\ Phil Boyer, President \\ 421 Aviation Way \\ Frederick, MD 21701 \\ (301) 695-2000}

A membership association representing 300,000 general aviation aircraft owners and pilots who fly general aviation aircraft for business and personal transportation. AOPA works closely with the Federal Aviation Administration, Department of Transportation, Nation Transportation Safety Board, the United States Congress, and with other aviation organizations to ensure that the interests of members and the entire general aviation community are represented at the Federal, State and local levels. The AOPA Safety Foundation conducts research, safety and educational programs and flight training clinics.

\author{
444 Air Diffusion Council \\ 111 E. Wacker Drive, Suite 200 \\ Chicago, IL 60601 \\ (312) 616-0800
}

Administers industry-wide testing and rating standards, encourages basic research into the behavior of air currents in enclosed areas, and participates in activities related to flexible air ducts standards.

\section{American Architectural Manufacturers Association (AAMA) 1540 E. Dundee Road Suite 310 \\ Palatine, IL 60067 \\ (708) 202-1350}

Dispenses technical information on architectural aluminum, storm windows, skylights, and window films. Provides technical information on coatings and finishes, weatherstrips, adhesives, and sealants, and sponsors product research and laboratory performance testing and a certification program for prime windows, storm windows and doors, and sliding glass doors.

\section{American Boiler Manufacturers Association (ABMA) \\ R. N. Mosher, Executive Director 950 North Glebe Rd., Suite 160 \\ Arlington, VA 22203 \\ (703) 522-7350}

ABMA members are manufacturers of utility, industrial, and commercial boilers, pressure vessels, and major components of the steam generating system. ABMA members are classified as either "active" or "associate." An active member is any person or organization that manufactures boiler systems or components for sale. An associate member is any person or organization that does work related to production, inspection, boiler insurance or boiler product technology. Associate members may also manufacture certain auxiliary apparatus. 


\section{American Coal Ash Association (ACAA)}

Samuel S. Tyson, Executive Director

1913 I Street, N.W., 6th Floor

Washington, DC 20006

(202) 659-2303

Members represent electric utility companies and systems, coal, and transportation companies; engineering, research, and development organizations; and ash marketing companies. Purposes are to provide technical assistance and information to coal ash producers, transporters, marketers, consumers, and other groups; to stimulate research and employment of ash uses, transport, and disposal; and to promote utilization of ash through advertising and public relations programs, dissemination of information on ash production, transport, storage, utilization, and research. ACAA works with a wide variety of end-user industries and with Federal and State Government agencies, to develop materials specifications and guidelines for use of coal combustion by-products and, more recently, for clean coal technology by-products as well. Maintains a 500-item library, including manuals and technical papers.

\section{American Coal Foundation (ACF) Beatrice Burns, Executive Director 113017 th Street, N.W., Suite 220 Washington, DC 20036 \\ (202) 466-8630}

Provides publications for grades K-12, some of which are available in classroom sets; a film guide; activities and science fair ideas. Also available free of charge is a coal sample kit that contains samples of peat, lignite, bituminous coal, and anthracite, along with a brief description of the formation and different types of coal. Now available for purchase or free loan (grades 7.12 and adult groups) is a slide presentation "Understanding the Greenhouse Effect and Global Climate Change." The complete kit contains 53 numbered slides, a script, teacher's guide, brochure and a onepage summary.

\section{American College of Nuclear Physicians (ACNP) Carol A. Lively, Executive Director 1101 Connecticut Avenue, N.W. Suite 700 Washington, DC 20036 (202) $857-1135$}

Composed of 1,600 physicians and scientists who are dedicated to the advancement of the science of nuclear medicine through study, education, and improvement of the socioeconomic aspects of the practice. ACNP also conducts a professional and public information program to educate the media and public about the practice of nuclear medicine, biological radiation, and low-level waste management issues.

\section{American Consulting Engineers Council (ACEC) \\ 1015 15th Street, N.W., Suite 802 \\ Washington, DC 20005 \\ (202) $347-7474$}

Provides energy management services to commercial building owners. ACEC, a federation of State and local associations, provides referrals to engineering firms, and distributes publications on general energy information for commercial buildings.

\section{American Council on Education Sheldon Steinbach, Vice President and Gen- eral Counsel 1 Dupont Circle, N.W., Suite 800 Washington, DC 20036 (202) 939-9355}

Provides information on pending energy legislation affecting colleges and universities. Provides information on ongoing energy education programs and examples of renewable energy and conservation projects undertaken by colleges and universities. All members of the academic community are invited to use the services of this organization.

\section{American Gas Association (AGA) Michael Baly III, President 1515 Wilson Boulevard Arlington, VA 22209 (703) $841-8400$}

Provides information on sales, finance, utilization, research, management, safety, accounting, and all phases of gas transmission and distribution. Sponsors competitions among primary and secondary students and public service and informational advertising. Promotes employee and public safety. Compiles a wide variety of national and regional statistical, economic, financial, and marketing studies; develops operating practices and gas rate schedules for every type of service for virtually all gas companies. Maintains an independent committee which compiles standards on construction and performance of appliances and equipment, as well as special committees in areas of industry interest. 


\section{American Iron and Steel Institute (AISI) \\ Andrew G. Sharkey, President \\ 1101 17th Street, N.W., Suite 1.300 \\ Washington, DC 20036 \\ (202) 452-7100}

Members include bas: manufacturess and individuals in the steel industry. Members operate steel mills, blast furnaces, finishing mills, and iron ore mines. Products include pig iron, steel ingots, sheets, plates, bars, shapes, strips, tin plate, nails, pipe and tubes, railroad rails, wire products, and other basic forms of ferrous metals. Conducts extensive research programs on manufacturing technology, basic materials, environmental quality control, energy and fuels consumption.

\section{American Lighting Association (ALA) 435 North Michigan Avenue \\ Chicago, IL 60611 \\ (312) 644-0828}

Provides general and technical information on the efficient use of lighting. The ALA (formerly the American Home Lighting Institute) is composed of manufacturers and their marketing representatives and showroom distributors. ALA also provides requestors with referrals to showroom distributors of energyefficient lighting products in their area.

\section{American Nuclear Energy Council (ANEC) \\ Edward M. Davis, President \\ 410 First Street, S.E. \\ Washington, DC 20003 \\ (202) 484-2670}

Organizations having an interest in any facet of the peaceful application of nuclear energy, including uranium suppliers, utilities, engineers/contractors, and equipment manufacturers. Purposes are to support development of nuclear power as an energy source; to coordinate and project the interests of the American nuclear industry to Congress and the Executive Dranch; to relate Congressional and Executive Branch actions affecting nuclear energy issues to member companies.

\footnotetext{
456 American Petroleum Institute (API) Charles J. DiBona, President 1220 L Street, N.W. Washington, DC 20005

Publications Department: (202) 682-8375

Library: (202) 682-8042
}

The American Petroleum Institute is a trade association that represents the domestic petroleum industry. For a list of current publications, call the Publications Department. For out-of-print API publications, contact the Library.

\section{American Plywood Association 7011 S. 19th Street P. O. Box 11700 \\ Tacoma, WA 98411 \\ (206) $565-6600$}

Provides information on the various aspects of structural wood panels. Builders and contractors may call with questions on energy conservation and the insulating properties of wood. The Association, representing 50 member companies in both the United States and Canada, is involved in quality testing and inspection, research and development, and product promotion.

\section{American Public Power Association (APPA) Larry Hobart, Executive Director 2301 M Street, N.W. Washington, DC 20037 (202) $467-2900$}

Members represent 1,750 municipally-owned electric utilities, public utility districts, State and countyowned electric systems, and rural cooperatives. Maintains library on the electric power industry. Conducts research programs, compiles statistics, and offers utility education courses. Holds annual conference and four major workshops each year -- Engineering and Operations; Legal Seminar; Energy/Consumer Services and Communications; Accounting, Finance, Rates and Information Systems.

\section{American Society for Engineering Education (ASEE) \\ 11 Dupont Circle, N.W., Suite 200 \\ Washington, DC 20036-1207 \\ (202) $986-8500$ \\ Fax: (202) 265-8504}

Professional and academic engineers interested in improving and expanding the energy conservation and solar engineering curricula of colleges and universities through the United States should contact ASEE. Forty committees within ASEE span a wide variety of interests and members are invited to take an active part in their work. 


\section{American Society for Testing and Materials (ASTM) \\ James A. Thomas, President \\ 1916 Race Street \\ Philadelphia, PA 19103 \\ (215) 299-5400}

ASTM members include engineers, scientists, managers, professionals, academicians, consumers, and skilled technicians who also hold membership as individuals in or as representatives of business firms, government agencies, educational institutions, and laboratories. Establishes voluntary stanciards for materials, products, systems, and services. Has 130 technical committees (each having 5 to 50 subcommittees). New committees are organized each year to keep pace with technological advances. Sponsors more than $\mathbf{4 0}$ symposiums each year. Has developed more than 9,000 standard test methods, specifications, classifications, definitions, and recommended practices now in use.

\section{American Society of Agricultural Engineers 2950 Niles Road \\ St. Joseph, MI 49085 \\ (616) 429-0300}

Responds to technical inquiries on biomass, alcohol fuels, vegetable oil fuels, solar energy, and wind energy. Publishes technical papers, books, conference proceedings, exports' anthologies on various subjects, and a bimonthly magazine entitled Agricultural Engineering. A listing of publications and prices is available upon request.

\section{American Society of Mechanical Engineers 345 East 47th Street \\ New York, NY 10017 \\ (212) 705-7722 \\ Fax: (212) 605-8750}

Supply engineers and technically-oriented laymen with information on standards and codes for heat transfer fluids, heat exchangers, and pressure vessels, including boilers and piping. Sponsors seminars and conferences on power generation and other mechanical engineering subjects. A publications catalog is available upon request.

\section{American Underground Space Association 51111 th Avenue, South Box 320}

Minneapolis, MN 55415

(615) 339-5403

As a multi-disciplinary, non-profit, professional organization involved in developing and using underground space, provides information and educational materials on underground space to its members and the general public. Provides a forum where technical, economic, social, environmental, and policy-related issues about developing and using underground space are discussed.

\section{Association of American Railroads (AAR) \\ Edwin L. Harper, President \& CEO \\ American Railroads Building \\ 50 F Street, N.W. \\ Washington, DC 20001 \\ (202) 639-2100}

Represents railroads operating in North America. The AAR conducts research and collects information in the following areas: alternative locomotive fuels; fuel security and management; the reduction of fuel consumption through engine modification, rail lubrication, and changes in railroad operations; and alternatives to diesel engines.

\section{Association of Energy Engineers (AEE) Ruth M. Bennett Information Services Director 4025 Pleasantdale Road, Suite 420 Atlanta, GA 30340 (404) 447-5083}

AEE members include engineers, architects, and other professionals with an interest in energy management and cogeneration, manufacturers and industries involved in energy and the environment. Promotes the advancement of the profession and contributes to the professional development of members. Conducts seminars. Sponsors the Cogeneration and Competitive Power Institute, the Environmental Engineers \& Managers Institute, and the Demand-Side Management Society.

\section{Association of Home Appliance Manufacturers 20 North Wacker Drive Chicago, IL 60606 (312) $984-5800$}

Supplies information on the energy efficiency of specific brands of major appliances. A publications list is available upon request. 


\section{Association of Pellet Fuel Industries 555116 th NE, Suite 250 \\ Bellevue, WA 98004 \\ (206) 453-8422}

Offers a directory of pellet appliance manufacturers and their products. Also provides an information referral service for retailers and manufacturers.

\section{Biomass Energy Research Association (BERA) \\ Donald L, Klass, President \\ 1825 K Street, N.W., Suite 503 \\ Washington, DC 20006 \\ (202) 785-2856}

Fax: (202) 223-4625

BERA is a nonprofit membership association founded in 1982 by industry and university researchers throughout North America who are interested in the development and commercial utilization of renewable, environmentally clean biomass energy systems. BERA's mission is to promote research in both the public and private sectors and to facilitate technology transfer from the laboratory to industry, information exchange, education, and international cooperation on biomass energy. BERA currently publishes an annual position statement on the Federal funding of biofuels research, demonstration, and technology transfer to the private sector; testifies before Congressional committees on Federal biomass energy programs; hosts bimonthly "Capitol Hill Luncheons" in Washington, DC, to improve communications and program coordination and to educate policy makers on the potential of biomass energy; operates a Consultants' Clearinghouse and a Speakers' Bureau for members; provides an annual award of $\$ 1,000$, a plaque, and a certificate to recognize outstanding biomass energy research or commercialization; responds to inquiries from the public and private sectors on biomass energy; provides objective evaluations of selected proposals and research reports; participates in national and international meetings and conferences on biomass energy; and maintains affiliation with the journal Bioresources Technology. Recently, BERA published a vendors' catalog of renewable energy hardware and systems for the purpose of promoting U.S. exports.

\footnotetext{
469 Brick Institute of America 11490 Commerce Park Drive Reston, VA 22091-1525

(703) 620-0010

Fax: (703) 620-3928
}

Offers information on the thermal properties of brick and its use in passive solar applications, as well as other aspects of brick design.

\section{Ceilings and Interior Systems Construction Association 579 West North Avenue Suite 301 \\ Elmhurst, IL 60126 \\ (708) 833-1919}

Answers inquiries on interior insulation systems, interior lighting, air control, sound absorption, acoustics, and access floors. Offers information regarding recommendations on seismic, glass reinforced gypsum, and access floors.

\section{Consumer Energy Council of America Research Foundation (CECA/RF) Ellen Berman, Executive Director 2000 L Street, N.W. \\ Suite 802 \\ Washington, DC 20036 (202) 659-0404}

Founded in 1973, CECA/RF is the nation's oldest public interest energy policy organization. CECA/RF provides a leading national resource pool of information, analysis, and expertise on a wide variety of energy initiatives; conducts in-depth analyses on economic and social impacts of energy policies; develops long-range conservation and loan management strategies for utility companies; designs pilot projects and conducts research on conservation initiatives for government agencies and private research foundations. CECA/RF has a primary commitment to ensuring reliable and affordable energy for all sectors of our Nation and, as such, places a strong emphasis on conservation and energy efficiency programs as the cornerstone of a sound energy economy. CECA/RF provides a forum for consensus among public and private sector organizations, State and local groups, businesses, utilities, consumers, environmentalists, government agencies, and others to further to consumer interests. CECA/RF is currently studying public policy issues relating to the environmental externalities of energy production, transmission siting and certification issues, and air pollution emissions trading under the Clean Air Act Amendments of 1990. CECA/RF maintains a library and information on $\$ 4$ billion oil overcharge funds and a data base on utility appliance rebate programs. 
472 Cooling Tower Institute (CTI)

Dorothy Garrison, Executive Director

P.O. Box 73383

Houston, TX 77273

(713) 583-4087

Goals are to improve technology, design, and performance of water conservation apparatus. Has developed standard specifications for cooling towers; provides inspection services. Conducts research through technical subcommittees. Sponsors workshops, seminars, and projects.

\section{Copper Development Association, Inc. 260 Madison Avenue New York, NY 10016-2401 (203) 625-8210}

Supplies information on the use of copper for the production of renewable energy equipment. The organization represents copper mining companies, fabricating companies (such as brass and wire mills), smelting and refining companies, and foundries.

\section{Earth Energy Association (EEA) George Haas, Executive Director 777 North Capitol Street, N.E., Suite 805 Washington, DC 20002 (202) 289-0868}

A non-profit trade association representing the Geothermal Heat Pump industry, whose members include electric utilities, manufacturers, distributors, dealers, architects, engineers, and builders. The EEA serves as a forum for the exchange of information affecting the Geothermal Heat Pump (GHP) industry and its relative trade allies; provides non-partisan credibility on behalf of the industry; maintains a communicative link with members of Congress and Federal agencies which oversee energy policy and Federal spending; serves as a strong advocate for new laws, regulations, and incentives for improved energy efficiency standards; gathers, analyzes, and distributes information which defines the scope, standards, and trends within the GHP industry; organizes and conducts conferences and seminars for utilities, trade organizations, and government agencies; maintains a library of pertinent published literature and historical data.

\section{Eastern Region Coalbed Methane Information Center The University of Alabama \\ Box 870211 \\ 205 Tom Bevill Building \\ Tuscaloosa, AL 35487}

Marcia S. Irvin

Information Specialist/Geologist

(202) 348-2839

Fax: (205) 348-9268

Provides information and research assistance on all aspects of coalbed methane research, development and field activities through the Eastern Regional Coalbed Methane Information Center. The Center, established in 1985, is a cooperative venture of the Gas Research Institute (GRI), ICF Resources, and the University of Alabama Libraries. The Center focuses primarily on the Black Warrior and San Juan basins but also provides material covering less known basins, including the Piceance, Powder River, Arkoma, Illinois, Wind River, Green River and all of the Appalachian areas. The Center is a non-circulating library. Photocopies of materials may be obtained at a nominal charge. The Center maintains a hard-copy collection of pertinent published literature on coalbed methane and related industry.

\section{Edison Electric Institute (EEI) Lynn LeMaster, Vice-President Government Relations 701 Pennsylvania Avenue, N.W. Washington, DC 20004-2696 (202) 508-5475}

Represents investor-owned electric utility companies operating in the United States. Has affiliated members in North, Central, and South America.

\section{Electrical Generating Systems Association (EGSA) \\ A. Tony Raucci, Executive Director 10251 W. Sample Road \#SV-B Coral Springs, FL 33065-3939 (305) 755-2677}

Members include manufacturers of devices used to generate electrical power through the use of an internal combustion engine or a gas turbine coupled to a generator; their suppliers and distributors. Conducts basic and advanced training programs. Compiles statistics. 


\section{Electricity Consumers Resource Council (ELCON) \\ John A. Anderson, Executive Director 1333 H Street, N.W., West Tower, 8th Floor Washington, DC 20006 \\ (202) 682-1390}

Represents industrial users of electricity. Represents viewpoints of industrial users of electricity users to suppliers, regulators, and State and Federal Government bodies. Promotes dialogue on electricity management. Researches reasons for increasing electricity costs and possible ways to contain the increase. Holds workshops and seminars; maintains library.

\section{Florida Solar Energy Industries Association Contact: Marcia K. Elder \\ 707 East Park Avenue \\ Tallahassee, FL 32301 \\ (800) 426-5899 (in Florida) \\ (305) 222-0971}

A statewide trade association of contractors, manufacturers, distributors, and suppliers of solar thermal, photovoltaic, and energy conservation equipment; promotes the solar energy industry in Florida. Provides general and technical information and assistance on solar energy and photovoltaics to the general public and professionals.

\section{Gas Appliance Manufacturers Association (GAMA) \\ C. Reuben Autery, President 1901 North Moore Street, Suite 1100 \\ Arlington, VA 22209 \\ (703) 525-9565}

Members are manufacturers of residential, commercial, and industrial gas appliances and equipment, including equipment used in the production, transmission, and distribution of fuel gases. Represents members before Federal and State legislative and regulatory bodies and consumer groups. Serves as a force for product improvement, a source of market statistics, and a means for product promotion and industrial publicity.

\section{Gas Processors Association (GPA) Mark F. Sutton, Executive Director 6526 East 60th Street \\ Tulsa, OK 74145 \\ (918) 493-3872}

Firms producing, processing, and handling natural gas liquids, and other hydrocarbon products (such as liquefied petroleum gases) at gas-processing plants. Develops technical standards and specifications for products; compiles basic data on hydrocarbon behavior, testing procedures, laboratory analysis, and plant safety practices. Cooperates with educational institutions on specific research projects; compiles statistics.

\section{Gas Research Institute (GRI) Stephen D. Ban, President and CEO Headquarters 8600 West Bryn Mawr Avenue Chicago, IL 60631 (312) $399-8100$}
Washington Operations
1331 Pennsylvania Avenue, N.W.
Suite 730 North
Washington, DC 20004-1703

Gas Research Institute (GRI) is a nonprofit membership organization of the natural gas industry. GRI plans, manages, and develops financing for a research and development program designed to advance natural gas supply, transport, storage, and end-use technologies and to conduct related basic research. New products, processes, and information resulting from GRI's results-oriented program provide cost savings and other benefits for the natural gas industry and gas consumers nationwide.

\section{Hearth Products Association Carter Keithley, President 1101 Connecticut Avenue, N.W., Suite 700 \\ Washington, DC 20036 (202) 857-1181 Fax: (202) 223-4579}

The Hearth Products Association is the national trade association for the hearth industry. The organization was founded in 1980 when the Fireplace Institute and the Wood Energy Institute united to form the Wood Heating Alliance. In January 1992, the Alliance officially changed its name to the Hearth Products Association to better reflect the diversity within the industry and the range of products and services offered by its members. Under the direction of industry leaders, HPA is making important strides in promoting the safe use of wood, coal, and other alternative fuels and in protecting the hearth industry's livelihood. 


\section{Home Ventilating Institute \\ Division of AMCA \\ 30 West University Drive \\ Arlington Heights, IL 60004}

Provides information on residential static and powered ventilation. Maintains a test/certification program for residential ventilating products, publishes the HVI Certified Products Directory, and has a referral network. Services are provided primarily for contractors, distributors, dealers, home builders, designers, and building code officials, but interested consumers will also be assisted. Has a training and certification program for installers of heat recovery ventilators.

\section{Hydronics Institute \\ 35 Russo Place \\ P.O. Box 218 \\ Berkeley Heights, NJ 07922 \\ (908) 464-8200}

The Hydronics Institute is a non-profit organization, established to improve and promote the use of hydronic (steam and hot water) heating and allied cooling systems. In addition to an extensive literature list, including detailed design guides for all types of hydronic heating, the Institute publishes a yearly ratings manual of boilers and radiation equipment. Services offered by the Institute range from one- to three-day schools around the country, on Hydronic Systems, to telephone assistance on sizing, operation, and design questions. A list of literature is available.

\section{Illuminating Engineering Society of North America (IESNA) William Hanley, Executive Vice President 345 East 47th Street \\ New York, NY 10017 \\ (212) 705-7913}

The Illuminating Engineering Society of North America was founded in 1906 to establish scientific lighting recommendations and to disseminate this information to all interested parties. It is the recognized authority on lighting in North America. Offers continuing education through section and regional meetings, technical conferences, and symposiums. The Society's membership includes engineers, architects, designers, educators, students, contractors, distributors, utility personnel, scientists, physicians and manufacturers. Almost 10,000 individual members and 550 sustaining member companies comprise the membership of IESNA. It publishes the IESNA Handbook, standards, recommended practices, etc., in addition to its monthly magazine, Lighting Design and Applications, and its bi-annual journal.

\author{
487 Independent Electrical Contractors \\ (IEC) \\ Dwight "Ike" Casey, Executive Vice \\ President \\ P. O. Box 10379 \\ Alexandria, VA 22310-0379 \\ (703) 549-7351
}

Members include independent electrical contractors, small and large, primarily open shop. Promotes the interests of members regardless of their labor affiliation; works to eliminate "unwise and unfair business practices" and to protect its members against "unfair or unjust taxes and legislative enactments." Sponsors electrical apprenticeship programs; conducts research and educational programs on estimating procedures, cost control, and personnel motivation. Represents independent electrical contractors to the National Electrical Code panel. Conducts surveys on volume of sales and purchases and on type of products used. Sponsors annual legislative workshop. Has formulated National Pattern Standards for Apprentice Training for Electricians.

\section{Independent Liquid Terminals Association (ILTA) John Prokop, President 1133 15th Street, N.W., Suite 204 Washington, DC 20005 (202) 659-2301}

Independent terminal companies that provide "for hire" services to handle, transfer, and store bulk liquid commodities. Members operate deepwater and barge terminals for the storage of liquid food products, such as animal fats and vegetable oils, molasses, and spirits. Some members operate petroleum pipelines. Objectives are to advise members of fending legislation and regulations and to respond to these proposals; to provide and facilitate the exchange of information among operators; to promote the safe and efficient handling of an increasing variety of liquid products. Maintains speakers' bureau and placement services. Operates library on bulk liquid terminal and storage information.

\section{Independent Lubricant Manufacturers Association (ILMA) \\ Nancy DeMarco, Executive Director 651 South Washington Street \\ Alexandria, VA 22314 \\ (703) 684-5574}

Independent compounders and blenders of automotive, industrial, and metal working lubricants and greases. Associate members are base stock, additive, and packaging equipment suppliers. Conducts educational and regulatory compliance programs. Repre- 
sents industry before Congress and Federal regulatory agencies and interacts with other industry groups. Compiles statistics; publishes monthly newspaper; maintains enforceable Code of Ethics.

\section{Independent Petroleum Association of America (IPAA) \\ Denise A. Bode, President \\ 1101 16th Street, N.W. \\ Washington, DC 20036 \\ (202) $857-4722$}

Members include independent oil and gas operators, royalty owness, and others (suppliers, drilling contractors, bankers, oil attorneys, trucking contractors, and rig building contractors) interested in the production of crude oil and natural gas. Represents small oil and natural gas producers in legislative and regulatory areas at the Federal level. Maintains speakers' bureau; compiles statistics.

\section{Institute of Gas Technology (IGT) \\ Bernard S. Lee, President \\ 3424 South State Street \\ Chicago, IL 60616 \\ (312) $567-3650$}

Nonprofit research and education organization founded in 1941. Conducts contract research for Government and industry in environmental and nonnuclear energy technology. Members include companies engaged in the production, processing, transmission, and distribution of natural gas and related fuels, oil and coal producers, engineering firms, and large energy users. Areas of research specialization include molten carbonate fuel cells, the application of biotechnology to energy and environmental problems, improved utilization technology, the conversion of coal, oil shale, biomass, and waste to clean energy, natural gas distribution research, and natural gas vehicles. Offers short courses in gas production, distribution, economics, and marketing. Sponsors symposiums on current topics in non-nuclear energy. Maintains library of over 300,000 volumes.

\section{International Association of Drilling Contractors (IADC) \\ Lee Hunt, President \\ P.O. Box 287 \\ Houston, TX 77210-4287 \\ (713) 5 , 3-7171}

Fax: (713) 578-0589

Membership comprises land and offshore drilling contractors, major and independent oil-and-gas producing companies, equipment manufacturers, oil field service and supply firms, and training facilities. Rep- resents the global drilling industry before legislative and regulatory bodies at the State, Federal, and international levels. Complies statistics on active rotary drilling rigs worldwide and on drilling safety. Publishes periodicals, reference books, training manuals, and forms. Conducts educational and professional meetings and seminars. There are 18 chapters worldwide, with headquarters in Houston, Texas, and other offices in Washington, DC, London, and the Netherlands.

\section{Interstate Natural Gas Association of America (INGAA) \\ Jerald V. Halvorsen, President 555 13th Street, N.W., Suite 300-West \\ Washington, DC 20004 \\ (202) 626-3200}

Trade association representing interstate natural gas pipelines in the United States and interprovincial pipelines in Canada. INGAA's members account for over 90 percent of the natural gas sold or transported in interstate commerce in the United States.

\section{National Association of Energy Service Companies (NAESCO) Terry Singer, Executive Director 1440 New York Avenue, N.W. Washington, DC 20005 (202) 371-7000}

Members include individuals and firms providing energy efficiency services or electrical or thermal energy as an unregulated business activity by using a range of performance-based contracting and financing mechanisms, and nonprofit and Government bodies interested in the energy service industry. Purpose is to provide industry representation at all regulatory and government levels. Seeks to inform the public regarding performance contracting and financing of alternative energy and energy conservation programs. Promotes the development, growth, and status of the energy service industry. Serves as an information clearinghouse through bimonthly publication Energy Efficiency Journal. Holds two major conferences yearly.

\section{National Association of Power Engineers (NAPE) C. Dalgard, Executive Director 2350 East Devon Avenue, Suite 115 Des Plaines, IL 60018 (312) 298-0600}

Professional society of power and stati., y engineers. Associate members are sales engireers and teachers of any phase of engineering. Areas of interest 
include air conditioning, compressed air, electric power, refrigeration, steam, and water. Promotes education in the power engineering areas. Secures and enforces license laws to prevent the destruction of life and property in the generation and transmission of power and to conserve of fuel resources of the Nation.

\section{National Association of State Utility Consumer Advocates (NASUCA) Debra Berlyn, Executive Director 1133 15th Street, N.W., Suite 575 Washington, DC 20005 (202) 727-3908}

The National Association of State Utility Consumer Advocates (NASUCA) is a national organization comprised of 44 offices of ratepayer advocates in 38 States and the District of Columbia. These advocates represent millions of American consumers served by investor-owned gas, telephone, electric, and water companies. It is the only national organization of its kind in the United States. NASUCA members are utility consumer advocate offices which operate independently from the regulatory commissions in their States. All are designated by State law to act as ratepayer advocates. The constituency, scope, and size of the member agencies vary. Some of the advocates are separately established utility advocate organizations, while others function as divisions or branches within larger State departments, such as the Office of Attorney General. Non-voting affiliate members of NASUCA serve utility consumers but these offices have not been created by State law nor do they have statewide authority.

\section{National Coal Association (NCA) Richard L. Lawson, President 1130 17th Street, N.W. Washington, DC 20036 (202) 463-2625}

Producers and sellers of coal, equipment suppliers, other energy suppliers, consultants, and coal transporters. Serves as liaison between the industry and Federal branches and agencies of Government. Keeps members informed of legislative and administrative actions concerning taxation. Works with industry, consumers, and Government agencies to control air pollution. Seeks improved conditions for export of steam and metallurgical coal. Collects, analyzes, and distributes industry statistics; makes special studies of competitive fuels, coal markets, production and consumption forecasts, and industry planning.

\section{National Electrical Contractors Association, Inc. (NECA)}

John M. Grau, Executive Vice President

3 Bethesda Metro Center, \#1100

Bethesda, MD 20814

(301) 657-3110

Comprised of electrical contractors erecting, installing, repairing, servicing, and maintaining elertric and telecommunications equipment, wiring, controls, and appliances. Provides labor relations and member services, including management development, marketing and sales support, research and education, codes and standards, government relations, and joint relations with suppliers of electric power and products. Also publishes monthly magazine, Electrical Contractor. There are approximately 4,000 member companies organized into 124 independent chapters nationwide.

\section{National Electrical Manufacturers Association (NEMA) Bernard H. Falk, President 2101 L Street, N.W. Washington, DC 20037 (202) $457-8400$}

Comprised of companies that manufacture equipment used for the generation, transmission, distribution, control, and utilization of electric power, such as electrical machinery, motors, wire and cable, and equipment for industrial automation, construction, medical diagnostic imaging, communication, and lighting. Objectives are: to maintain and improve quality and reliability of products; to ensure safety standards in manufacture and use of products; to organize and act upon members' standards, testing, and certification issues, international trade energy conservation and efficiency, marketing opportunities, economic matters, and product liability. Develops product standards covering such matters as nomenclature, ratings, performance, testing, labeling and dimensions; participates in developing National Electrical Code and advocates its acceptance by State and local authorities; contributes to the development of American National Standards; conducts regulatory and legislative analyses on issues of concern to electrical manufacturers; complies and issues periodic summaries of statistical data on such factors as sales, new orders, unfilled orders, cancellation, production, and inventories.

500 National Hydropower Association
(NHA)
Linda Church Ciocci
55513 th Street, N.W., Suite 900 East
Washington, DC 20004
(202) 637-8115


Association of independent power producers, investor-owned utilities, public utilities, equipment manufacturers, developers, engineers, and attorneys involved in the hydroelectric industry. The association serves to represent the industry at all regulatory and governmental levels. Promotes pumped storage projects and development opportunities overseas. Dispenses information through a monthly newsletter and an annual conference.

\section{National Lubricating Grease Institute (NLGI) \\ Edward J. Palecki, General Manager \\ 4635 Wyandotte Street, Suite 202 \\ Kansas City, MO 64112 \\ (816) $931-9480$}

Represents companies manufacturing or selling all types of lubricating greases; suppliers of such companies; technical and educational organizations. Promotes research and testing for the development of better lubricating greases and for providing better grease lubrication engineering service to industry; collects and disseminates technical data; conducts forums and educational program.

\section{National Rural Electric Cooperative Association (NRECA) \\ Bob Bergland, Executive Vice President 1800 Massachusetts Avenue, N.W. Washington, DC 20036 \\ (202) $857-9500$}

National service organization representing rural electric cooperatives, public power districts, and public utility districts in 46 States. Activities include legislative representation; energy, regulatory and legal expertise; industry public relations; publication of a magazine and newsletter; management institutes; professional conferences; training and energy research and development consulting services; insurance and safety programs; women's and youth programs; wage and salary surveys; and an international program.

\section{National Stripper Well Association (NSWA)}

Tom Haywood, Executive Vice President 804 Eighth Street

Wichita Falls, TX 76301

(800) 761-1566
Federation of regional and State associations of producers of crude petroleum from small wells.

\section{Natural Gas Supply Association (NGSA) \\ Nicholas J. Bush, President \\ 1129 20th Street, N.W., Suite 300 \\ Washington, DC 20036 \\ (202) 331-8900}

Represents companies that produce and market over 90 percent of the domestic natural gas consumed annually. Established in 1965, NGSA encourages expanded use of natural gas and a regulatory climate that fosters steady supplies and competitive markets. NGSA is active on all Federal legislative and regulatory issues involving the exploration for, production of, and marketing of natural gas. It has a State information program with outreach to public utility commissions. NGSA's primary economic product is its zinual deliverability survey.

\section{Natural Gas Supply Information Center \\ Ron W. Henderson, Information Specialist The University of Alabama \\ Box 870211 \\ 205 Tom Bevill Building \\ Tuscaloosa, AL 35487-0211 \\ (205) 348-9268}

Fax: (205) 348-9268

One of four Natural Gas Supply Information Centers (NGSICS) established by the Gas Research Institute (GRI). Each NGSIC features the most up-to-date noncirculating collection of research results on natural gas production from conventional, gas shale, coal seam, and tight gas sand reservoirs. The Centers' Information Specialists conduct searches and gather information on chosen topics at no charge from available published and unpublished sources. Topic areas include geology and geophysics, well stimulation and completion, reserve appreciation, environmental implications of producing and processing natural gas, quality control, and field operations. The NGSICs offer their services to the gas industry, both locally and throughout the United States, and the research community. The information available at the NGSICs is intended to help ensure a more secure supply of natural gas for the Nation's consumers. GRI's other three NGSICs are located at the Colorado School of Mines (Golden, $\mathrm{CO}$ ), Marietta Collete (Marietta, $\mathrm{OH}$ ), and the University of Houston (Houston, TX). 


\section{North American Electric Reliability Council (NERC) \\ Michael R. Gent, President \\ Princeton Forrestal Village, 116-390 Village \\ Boulevard \\ Princeton, N] 08540-5731 \\ (609) 452-8060}

A nonprofit corporation owned by nine regional councils, NERC is the principal organization for coordinating, promoting, and communicating the reliability of North America's electric utilities. The members of the regional councils and one affiliate are individual electric utilities from all ownership segments of the electric utility industry-investor-owned, municipal, rural electric cooperatives, and Federal utilities. These utilities account for virtually all the electricity supplied in the United States, Canada, and the northern portion of Baja, California, Mexico. NERC annually review's the reliability and adequacy of the bulk electricity systems in North America, maintains several data bases (including the Generating Availability Data System), facilitates development of reliability-related planning and operating criteria and standards, and publishes related reports and reference documents.

\section{Petroleum Marketers Association of America (PMAA) \\ Phillip R. Chisolm, Executive Vice President 1120 Vermont Avenue, N.W., Suite 1130 \\ Washington, DC 20005 \\ (202) 331-1198}

Federation of 44 State and regional petroleum marketing associations with approximately 11,000 independent wholesale petroleum marketers (jobbers) and retail fuel oil dealers as members. Seeks to preserve the private enterprise risk-reward system; prevent undue economic concentration; insure a favorable competitive climate in petroleum distribution; and encourage an adequate supply of petroleum products in order to best serve the customer.

\section{Potential Gas Committee Potential Gas Agency Colorado School of Mines Harry Kent, Director Golden, CO 80401 (303) 279-4320}

Provides estimates of the potential supply of natural gas which, in conjunction with estimates of proved reserves of natural gas, make possible an appraisal of long-range supply. Comprised of volunteer members from the natural gas industry, government agencies, and academic institutions who are concerned with natural gas resources. Functions independently but with the guidance and assistance of the Potential Gas Agency of the Colorado School of Mines.

\section{Service Station Dealers of America} (SSDA)

D. G. "Jim" Daskal, General Counsel

801 N. Fairfax Street \#109

Alexandria, VA 22314-1757

(703) 548-4736

Service station operators who are members of affiliated State and local associations.

\section{Underground Space Center University of Minnesota 790 Civil and Mineral Engineering Building 500 Pillsbury Drive, SE Minneapolis, MN 55455 (612) 624-0066}

As a research center for underground space use, planning, and habitability, determines guidelines for the design and structure of underground facilities. Monitors energy use in underground facilities and building foundations. Provides technical information on underground design and construction to professions and the general public. Additional research areas include the underground urban infrastructure; geomechanics; frost heave in soils; and building weatherization.

\section{U.S. Council for Energy Awareness (USCEA) Phillip Bayne, CEO \& President 1776 I Street, N.W., Suite 400 Washington, DC 20006 (202) 293-0770}

Consists of representatives from electric utilities, manufacturers, industrial firms, research and service organizations, educational institutions, labor groups, and Government agencies engaged in development and utilization of nuclear energy, especially nuclear-produced electricity, and other energy matters. Maintains speakers' bureau; compiles statistics and public attitude data; operates library of books, periodicals, government documents, and audiovisual material.

\section{U.S. Enrichment Corporation (USEC) Jan Kyland Kermit Laughton 2300 M Street, N.W. Washington, DC 20037 (202) 466-8900} Fax: (202) 376-6926

Produces and sells uranium enrichment services to domestic and international utility customers. 


\section{Index}

\section{A}

Abandoned mine land, 354

Acid rain research, 182

Actinide chemistry, 174

Adiabatic diesels, 66

Advanced electric systems, 51

Advanced gas turbine, 207

Advanced Light Source, 325

Advisory Committees, 7 - 14

Affordable Housing Act, 349

AGA, 452

Agricultural energy use, 335

Agricultural engineers, 461

Air Conditioning Contractors of America, 441

Air currents in enclosed areas, 444

Air Diffusion Council, 444

Air ducts standards, 444

Air pollution data, 379

Air quality, 379 indoor, 378

Air Transport Association of America, 442

Air, water, and radiation protection, 111

Aircraft Owners and Pilots Association, 444

Airlines, 442

Alabama, 386

Alaska, 387

Alaska Power Administration, 330

Albuquerque Operations Office, 293

Alcohol, regulation of, 367

Alcohol fuels, 1, 68

Alcohol, Tobacco, and Firearms, 367

Alternative fuels, 67, 138

Alternative Fuels Data Center, 69

American Architectural

Manufacturers Association, 445

American Boiler Manufacturers Association, 446

American Coal Ash Association, 447

American Coal Foundation, 448

American College of Nuclear Physicians, 449

American Consulting Engineers Council, 450

American Council on Education, 451

American Gas Association, 452
American Iron and Steel Institute, 453

American Lighting Association, 454

American Nuclear Energy Council, 455

American Petroleum Institute, 456

American Plywood Association, 457

American Public Power Association, 458

American Samoa, 388

American Society for Engineering Education, 459

American Society for Testing and Materials, 460

American Society of Agricultural Engineers, 461

American Society of Mechanical Engineers, 462

American Statistical Association Committee on Energy Statistics, 7

American Underground Space Association, 463

Ames Laboratory, 298

Anthracite coal, 316

API, 456

Appliance efficiency standards, 75

Appliance labeling program, 76

Appliance manufacturers, 466

Appliance test procedures, 76

Appropriate technology, 3

Argonne National Laboratory, 299

Arizona, 389

Arkansas, 390

ASA, 7

Ash utilization, 447

Association of American Railroads, 464

Association of Energy Engineers, 465

Association of Home Appliance Manufacturers, 466

Association of Pellet Fuel Industries, 467

ASTM, 460

ATF, 367

Atlanta Support Office, 79

Audiovisuals and exhibits, 265

Automotive engine emissions, 5

B

Bartlesville Energy Technology Center, 5

Bartlesville Project Office, 296

Basic Energy Sciences, 172

Basic Energy Sciences Advisory Committee, 9 
Battelle Pacific Northwest Laboratory, 320

BESAC, 9

Bettis Atomic Power Laboratory, 317, 318

Bioenergy Coordinating Committee, 177

Biofuels, 68

Biogasoline, 68

Biological radiation, 449

Biology research, 191

Biomass, 1

Biomass energy, 50

Biomass Energy Research Association, 468

Biomass resources, 383

Bioprocessing, 60

Biosciences, 177

Biotechnology, 177

Black Warrior Basin, 475

BLM, 351

BLS, 358

Board of Contract Appeals, 224, 231

Boiler Manufaciurers Association, 446

Boiler systems, 207

BOM, 352, 356

Bonneville Power Administration, 331

Boston Support Office, 79

Brick Institute of America, 369

Brookhaven National Laboratory, 300

Buena Vista Hills, 217

Building Equipment Division, 74

Building technologies, 71

Buildings energy conservation standards, 77 energy efficiency, 73

Bureau of Alcohol, Tobacco, and Firearms, 367

Bureau of Census, 338

Bureau of Economic Analysis, 339

Bureau of Labor Statistics, 358

Bureau of Land Management, 351

Bureau of Mines, 352, 556

Business assistance, 3

California, 391

Carbon dioxide research, 193

CAREIRS, 1

Ceiling and Interior Systems Construction

Association, 470

Center for the Utilization of Federal Technology, 346

Ceramic engine components, 70

Ceramic gas turbines, 66

Ceramics Research, 173

CERCLA, 110

Chemical industry statistics, 341,381
Chemical Sciences, 174

Chicago Operations Office, 297

Chicago Support Office, 79

Civilian Laboratories, 245

Civilian radioactive waste management, 281

Civilian reactor development, 255

Clean Coal Technology, 206

Climate data, 345

Coal

education materials, 448

statistical data, 138

Coal and coal technology export program, 199

Coal Ash Association, 447

Coal industry, 497

Coal liquefaction, 316

Coal mine safety, 360

Coal preparation, 207, 316

Coal research, 316

Coal technology, 205

Coal Technology Data Base, 316

Coal-based fuels, 207

Coalbed Methane Information Center, 475

Cogeneration, 56

Cogeneration and Competitive Power Institute, 465

Cogeneration systems, 55

Colleges and universities

Colorado, 392 conservation projects, 451

Combustion, 60

Combustion equipment, 56

Committee on Energy and Commerce, 376

Committee on Energy and Natural Resources, 370

Community energy systems, 51

Compact Ignition Tokamak, 303

Comprehensive Environmental Response,

Compensation and Liability, 110

Computer science, 181

Computer software, 2

Congressional hearings, 15

Congressional, intergovernmental and international affairs, 15

Connecticut, 393

Conservation and Renewable Energy Inquiry and Referral Service, 1

Construction safety, 118

Consumer advocates, 496

Consumer Affairs, 265

Consumer Energy Council of America Research Foundation, 471

Consumer Price Index, 358

Contract Disputes Act, 231

Cooling degree-days, 345

Cooling Tower Institute, 472

Copper Development Association, Inc., 473 
Council on Environmental Quality, 380

CPI, 358

Crude oil recovery, 5

D

Dallas Support Office, 79

Data collection forms, 4

Daylight saving time, 362

Decommissioning of nuclear plants, 382

Defense Department, 347

Defense Programs, 19

Degree-day data, 345

Delaware, 394

Demand-Side Management Society, 465

Denver Support Office, 79

Department of Agriculture, 335

Department of Defense, 347

Department of Energy

Contracting regulations, 232

doing business with, 233

Public Affairs, 265

Department of Transportation programs, 361

Disadvantaged Business Utilization, 42

District of Columbia, 395

District heating, 51

DOE contracting rules, 232

DOE research in progress, 6

DOE research projects, 6

DOE This Month, 265

DOE waste material, 152

Drilling Contractors, 492

Drilling technology, 5

E

Earth Energy Association, 474

Earth Science Data Directory, 357

Earthquakes, 357

Eastern Region Coalbed Methane Information Center,

475

Economic accounts, 339

Economic indicators, 339

Economic Regulatory Administration, 221

Edison Electric Institute, 476

Education Programs, 195

EEI, 476

EES, 82

EIA, 133

EIA press releases, 4

EIA publications, 4

ELCON, 478

Electric cooperatives, 337
Electric utility appliance rebates, 471

Electric utility industry, 476

Electric vehicles, 65

Electrical Code, 487, 499

Electrical codes and standards, 498

Electrical Contractors, 487

Electrical Contractors Association, 498

Electrical Generating Systems Association, 477

Electrical machinery, 499

Electrical Manufacturers Association, 499

Electricity

load levelling, 53

reliability, 52

statistical data, 138

transmission, 52, 53

Electricity Consumers Resource Council, 478

Electricity systems reliability, 506

Electrochemistry, 53

Electron microscopes, 325

Elk Hills, 217

EMAC, 8

Emergency Petroleum Allocation Act, 221

Emissions data, 379

Employment Statistics, 359

Energy and the elderly, 349

Energy assistance, 348

Energy Biosciences, 177

Energy conservation, 1

Energy conservation standards buildings, 77

Energy data, 4

Energy Demand Policy, 268

Energy efficiency, 4

Energy Efficiency Journal, 494

Energy efficiency services, 494

Energy efficiency standards, 75

Energy emergencies, 244

Energy Engineers, 465

Energy Extension Service, 82

Energy guide labels, 75

Energy industries trade development, 342

Energy Information Administration

Office of the Administrator, 133

statistical policies, 144

Energy intensive processes, 59

Energy Management, 51, 465

Energy management services, 451, 494

Energy performance standards, 75

Energy policy, 271, 471

Energy publications, 6

Energy research and development, 168

Energy resources, 357

Energy Science and Technology Software Center, 2

Energy Service Companies, 494 
Energy technology policy, 274

Energy Technology Visuals Collection, 236

Energy-efficient lighting products, 454

Energy-related health effects, 191

Energy-Related Inventions Evaluation, 344

Energy-Related Inventions Program, 81

Energy-related pollutants, 304

Energy-related taxes, 368

Energy-related taxes and tax credits, 368

Energy-saving appropriate technologies, 3

Engine design, 66

Engineering education, 195, 459

Enhanced oil recovery, 5

Environment, safety and health information, 97

Environmental Analysis, 272

Environmental and safety concerns, 93

Environmental Auditing Training, 112

Environmental compliance policies, 106

Environmental Impact Statements, 380

Environment Measurements Laboratory, 304

Environmental policy, 271 effects on energy industries, 93

Environmental Protection Agency, 378

Environmental Restoration, 8

Environmental Restoration and Waste Management Advisory Committee, 8

Environmental Sciences, 193

EPA, 378

EPAA, 221

Epidemiologic activities, 129

Epidemiologic studies, 129

Epidemiological research, 321

ERA, 221

ERIP, 81

ESTSC, 2

Exploration and production of oil and natural gas, 210

Export control of nuclear technology, 242

Export of electricity, 215

Export of natural gas, 216

Extraction technologies, 208

$\mathbf{F}$

Farm use of energy, 335

Federal Energy Management Programs, 78

Federal Energy Regulatory Commission, 290

Federal Government

energy use, 78

Federal Highway Administration, 363
Federal lands, 351, 353

Federal onshore leases, 351

Federal Taxpayers Service Line, 368

FERC, 290

FERC publications, 292

Fermi National Accelerator Laboratory, 301

FHA, 363

Fire protection, 118

Fireplace Institute, 483

Fleet vehicles, 65

Florida, 396

Florida Solar Energy Industries Association, 479

Fluidized bed coal combustion, 207

Fly ash, 447

Foreign Trade, 338

Forest biomass energy, 336

Forest biomass resources, 383

Forest Service, 336

Formerly Utilized Sites Remedial Action Project, 314

Fossil fuel technology, 5

Freedom of Information and

Privacy Acts Branch, 235

Fuel cell vehicles, 64

Fuel cells, 218, 220

Fuel oil dealers, 507

Fuel Use Act, 215

Fuel wood, 336

Fuels Spill Test Facility, 204

Fusion energy, 185, 303

Fusion plasma phenomena, 188

FUSRAP, 314
G

GAO, 384

Gas and Petroleum Exploration, 210

Gas and Petroleum Technologies, 208

Gas Appliance Manufacturers Association, 480

Gas deliverability, 504

Gas pipelines, 493

Gas Processors Association, 481

Gas producers, 504

Gas Research Institute, 482

Gas resource estimates, 508

Gas Technology, 491

Gas utilities, 452

Gas-processing plants, 481

Gas-to-liquid conversion processes, 209

Gaseous Diffusion Plants, 314

GDP, 339 


\section{INDEX}

General Accounting Office, 384

General aviation, 443

Geographic information systems, 357

Geologic maps, 357

Geological Information, 352

Geological Survey, 352, 357

Geology, 357

Georgia, 397

Geoscience research, 175

Geothermal, 1

Geothermal Division, 47

Geothermal Heat Pump industry, 474

Geothermal Loan Guarantee Program, 83

GIS, 357

Global warming, 193

Government Printing Office, 385

Government publications, 385

GPO, 385

Grand Junction Projects Office, 305

Grants, 83

Greenhouse gases, 193

GRI, 482

Gross Domestic Product, 339

Guam, 398

\section{H}

Hanford Environmental Health Foundation, 321

Hanford Site, 319

Hawaii, 399

Hazardous Materials Information System, 366

Hazardous materials transportation, 366

Health and Environmental Research, 190

Health and Environmental Research Advisory Committee, 10

Health Effects and Life Sciences Research, 191

Health physics, 130

Health surveillance data, 129, 131

Hearth Products Association, 483

Hearings and Appeals, 224

Heat Pump industry, 474

Heat recovery ventilators, 484

Heat transfer, 60

Heating degree-days, 345

Heating systems, 485

Heavy oil upgrading technologies, 209

HEPAP, 11

HERAC, 10

High Energy Physics, 179

High Energy Physics Advisory Panel, 11

High explosives safety, 118

High Temperature Materials Laboratory, 70

Highway Information Management, 363
Highway speed limit, 364

Highway use of motor fuels, 363

Home Ventilating Institute, 484

Hot atom chemistry, 174

House Liaison, 18

HUD USER, 350

Human genome, 191

Hydroelectric, 1, 46

Hydroelectric industry, 500

Hydronics Institute, 485

Hydropower Association, 500

IAEA, 240

Idaho, 400

Idaho Field Office, 306

Idaho National Engineering Laboratory, 306

IGT, 491

Illinois, 401

Illuminating Engineering Society of North America, 486

Import Administration, 340

Import and export of natural gas, 216

Independent Electrical Contractors, 487

Independent Liquid Terminals Association, 488

Independent Lubricant

Manufacturers Association, 489

Independent Petroleum Association of America, 490

Indiana, 402

Indoor Air Quality, 378

Industrial Energy Efficiency, 56

Industrial hygiene, 130

Industrial Processes, 59, 62

Industrial Technologies, 54 technology transfer, 58

Industrial use fuel wood, 336

Industrial users of electricity, 478

Industrial waste, 57

Inertial Confinement Fusion, 30

Inertial confinement systems, 189

Information exchanges, 6

INGAA, 493

Institute of Gas Technology, 491

Institutional conservation program, 83, 84

Insulating properties of wood, 457

Insulation systems, 470

Intergovernmental Affairs, 17

International Association of Drilling Contractors, 492

International Atomic Energy Agency, 240

International Energy Analysis, 278

International Energy Organizations, 279

International energy policy, 278 
International Minerals, 356

International Nuclear Policy, 249

International organizations, 279

International Thermonuclear

Experimental Reactor, 186, 187, 303

International Trade Administration, 341

International Trade Commission, 381

International transmission facilities, 215

Interstate Natural Gas Association of America, 493

Inventions, 81,344

Investor-owned electric utilities, 476

Jowa, 403

IPAA, 490

Isotope production and distribution, 260

ITC, 381

ITER, 186, 187, 303

$\mathbf{K}$

Kansas, 404

Kansas City Support Office

Kentucky, 405

$\mathbf{L}$

Laboratory Management Division, 246

Laramie Project Office, 307

Lawrence Berkeley Laboratory, 325

Lawrence Livermore National Laboratory, 326

Leasable minerals, 353

Legislation, 18

Licensing of nuclear plants, 382

Life sciences, 191

Lifetime extension for light water reactors, 259

Lighting, 454

Lighting Design and Applications, 486

Lighting recommendations, 486

Lighting systems, 470

LIHEAP, 348

Liquefied Gaseous Fuels Spill Test Facility, 204, 312

Liquid fossil fuel technology, 5

Liquid Fuels Technology, 307

Liquid Terminals Association, 488

Load levelling, 53

Los Alamos National Laboratory, 294

Louisiana, 406

Low Income Home Energy Assistance Program, 348

Low-Level Radioactive Waste Policy Act, 382

Lubricant Manufacturers Association, 489

Lubricant technologies, 70

Lubricants and greases, 489, 501

Lubricating Grease Institute, 501

M

Machine-readable files, 4

Magnetic confinement systems, 189

Magnetic fusion energy, 303

Magnetohydrodynamics, 218, 220, 316

Maine, 407

Maps, 357

Maryland, 408

Mass transit programs, 365

Massachusetts, 409

Materials Processing, 62

Materials Sciences, 173

Mathematical and computer sciences, 181

Measurement and control systems, 61

Mechanical Engineers, 462

Membrane systems, 61

Metallurgy and Ceramics Research, 173

METC, 308

Michigan, 410

Microbial sciences, 177

Mileage of roads and streets, 363

Mine Safety and Health Administration, 360

Mineral and Mining Information, 352

Minerals, 356

Minerals Management Service, 353

Minerals Yearbook, 356

Mining machinery, 340

Mining Reclamation, 354

Minnesota, 411

Minority Economic Impact, 41

Minority educational infrastructure, 41

Minority energy consumption, 41

Minority-owned businesses, 42

Mississippi, 412

Missouri, 413

Monitored Retrievable Storage, 288

Montana, 4/4

Morgantown Energy Technology Center, 308

Motor oil manufacturers, 489

MRS, 288

MSHA, 360

Multimodal transportation of hazardous materials, 366

Municipal solid wastes, 55

Municipal wastes, 57

$\mathbf{N}$

NAPAP, 182

NASUCA, 496

NATAS, 3

National Accelerator Laboratory, 302 


\section{INDEX}

National Acid Precipitation Assessment Program, 182

National Appropriate Technology Assistance Service, 3

National Association of Energy Service Companies, 494

National Association of Power Engineers, 495

National Association of State Utility Consumer Advocates, 496

National Climatic Data Center, 345

National Coal Association, 497

National Coal Council, 12

National Coal Technology Data Base, 316

National Electrical Code, 487, 499

National Electrical Contractors Association, Inc., 498

National Electrical Manufacturers Association, 499

National Energy Information Center, 4

National Energy Modeling System, 147

National Environmental Policy Act, 19, 113

National Hydropower Association, 500

National Institute for

Petroleum and Energy Research, 5

National Institute of Standards and Technology, 344

National Laboratories, 245

National Lubricating Grease Institute, 501

National Maximum Speed Limit, 364

National Oceanic and Atmospheric Administration, 345

National Petroleum Council, 13

National Renewable Energy Laboratory, 309

National Rural Electric Cooperative Association, 502

National Stripper Well Association, 503

National Technical Information Service, 346

Natural gas appliances, 480

Natural gas deliverability, 504

Natural gas pipelines, 493

Natural gas processors, 481

Natural gas producers, 504

Natural gas research, 482

Natural gas resource estimates, 508

Natural Gas Supply Association, 504

Natural Gas Supply Information Center, 505

Natural gas technology, 491

Natural gas utilities, $\mathbf{4 5 2}$

Natural gas vehicles, 69,491

Naval Fuel Material Facility, 329

Naval nuclear propulsion, 318

Naval Oil Shale Reserves, 217

Naval Petroleum and Oil Shale Reserves, 310

Naval Petroleum Reserves, 217, 311

Naval Reactors Facility, 317

NCA, 497

NCC, 12

Nebraska, 415

NEIC, 4
NEMA, 499

NEMS, 147

NEPA, 19, 113

NERC, 506

Nevada, 416

Nevada Field Office, 312

Nevada Test Site, 312

New Hampshire, 417

New Jersey, 418

New Mexico, 419

New York, 420

New York Support Office, 79

NGSA, 504

NIPER, 5

NIST, 344

NOAA, 345

Nonconventional Source Fuel Credit, 369

Nonproliferation, 237

North American Electric Reliability Council, 506

North Carolina, 42!

North Dakota, 422

NPC, 13

NREL, 309

NTIS, 346

Nuclear

statistical data, 138

Nuclear Directed Energy Weapons, 27

Nuclear Energy Council, 455

Nuclear energy industry, 511

Nuclear industry, 455

Nuclear materials, 35

Nuclear materials production, 29

Nuclear medicine, 449

Nuclear medicine research, 192

Nuclear Physics, 180

Nuclear power plants decommissioning, 382

licensing, 382

regulation, 382

Nuclear reactor development, 248

Nuclear Regulatory Commission, 382

Nuclear safety at DOE facilities, 98

Nuclear Safety Enforcement, 101

Nuclear safety oversight, 98

Nuclear Safety Radiological Oversight, 104

Nuclear Waste Fund, 285

Nuclear Waste Policy Act, 281, 382

Nuclear weapons transportation safeguards, 26

Nuclear weapons design and safety research, 27

Nuclear weapons production, 21

Nuclear weapons production sites, 36

Nuclear Weapons Stockpile Memorandum, 35

NWPA, 281 
Oak Ridge National Laboratory, 313

Oak Ridge Operations Office, 314

Occupational medicine, 132

Occupational safety, 118

Ocean circulation, 193

Ocean thermal energy, 1

Ocean thermal energy technology, 46

OCS, 353

Office of Fossil Energy, 200

Office of Public Affairs, 265

Office of Scientific and Technical Information, 6

Office of Surface Mining Reclamation and Enforcement, 354

Offshore leasing program, 353

Ohio, 423

Oil and gas extraction, 208

Oil and gas leases

Federal lands, 351

Oil and gas operators, 490

Oil and Gas Processing, 209

Oil and gas reserves, 137

Oil and gas statistical data, 134

Oil and Natural Gas Policy, 270

Oil processing, 209

Oil shale, 5, 307

Oil shale extraction technologies, 218, 220

Oil Shale Retort, 307

Oil shales, 308

Oklahoma, 424

On-shore leasing program, 351

Oregon, 425

ORNL, 313

OSM, 354

OSTI, 6

Outer Continental Shelf, 353

Ozone depletion, 193

\section{$\mathbf{P}$}

Pacific Northwest Laboratory, 320

Pantex Program Office, 23

Paratransit systems, 365

Particle physics, 301

Passive solar applications, 479

Peat resources, 316

Pellet Fuel Industries, 467

Pennsylvania, 426

Personal income, 339

PETC, 316

Petrochemical industry statistics, 341

Petroleum equipment, 343
Petroleum Exploration, 210

Petroleum extraction, 5, 296

Petroleum industry, 456

Petroleum Marketers Association of America, 507

Petroleum overcharge cases, 221

Petroleum Overcharge Distribution and Restitution Act of 1986, 224

Petroleum product specifications, 460

Petroleum Violation Escrow Oversight Program, 80

Philadelphia Support Office, 79

Photochemistry, 174

Photograph and slide collection, 236

Photovoltaics, 1, 49

Pipelines, 493

Pittsburgh Energy Technology Center, 316

Pittsburgh Naval Reactors Office, 317

Plasma etching of electronic circuitry, 303

Plywood Association, 457

PMAA, 507

PNL, 320

Portsmouth Site Office, 315

Potential Gas Committee, 508

Power Engineers, 495

Power Marketing Administrations, $330-334$

Price indices, 358

Princeton Beta Experiment-Modified, 303

Princeton Plasma Physics Laboratory, 303

Privacy Act, 235

Process electrolysis, 62

Processing technologies for oil and gas, 209

Propulsion Systems, 64

Public Affairs

Department of Energy, 265

Publications, 4, 6, 292, 346, 384, 385, 456

Publicly owned electric utilities, 458

Puerto Rico, 427

Pumped storage projects, 500

$\mathbf{R}$

Radiation chemistry, 174

Radiation treatment, 192

Radio-pharmaceutical applications, 192

Radioactive materials transportation of, 382

Radioactive waste, 152 transportation, 288

Radioactive Waste Management, 281

Radiological control, 104

Railroads, 464

Ratepayer advocates, 496

RCRA, 110 
REA, 337

Rebate programs, 471

Recycling of waste lubricating oil, 5

Regional Biomass Program, 80

Renewable energy, 1, 43, 45

Renewable energy equipment, 473

Renewable energy hardware and systems, 468

Renewable energy technology, 309

Requests for Proposals, 233

Research in progress, 6

Resource Conservation and Recovery Act, 110

Rhode Island, 428

Richland Field Office, 319

Rocky Flats Program Office, 22

Royalty collection, 353

Rural Electric Cooperative Association, 502

Rural electric cooperatives, 337

Rural Electrification Administration, 337

$\mathbf{S}$

Safety

non-nuclear, 116

Safety of Soviet designed reactors, 251

Safety performance assessments, 123

Safety Performance Measurements System, 118

San Francisco Field Office, 324

San Francisco Support Office, 79

San Juan basins, 475

Sandia National Laboratories, 295

Savannah River Operations Office, 328

SBIR, 176

Schenectady Naval Reactors Office, 329

Science and Technology Advisor, 20

Science Education Programs, 195

Scientific and technical information, 346

Scientific and Technical Information Program, 6

Scientific and technical reports, 6

SEAB, 14

Seattle Support Office, 79

Secretary of Energy Advisory Board, 14

Security Evaluations, 94

Senate Liaison, 18

Separation technologies, 61

SERI, 309

Service Station Dealers of America, 509

Shared energy cooperatives, 51

Silviculture, 336

Small and Disadvantaged Business Utilization, 42

Small Business Innovation Research, 176

Small businesses, 42

Soft $x$-ray lasers, 303

Software, 2, 6
Solar building technologies, 72

Solar energy, 48, 50

Solar energy conversion technologies, 309

Solar energy industry, 479

Solar Energy Research Institute, 309

Solar Heating and Cooling Information Center, 1

Solar insolation data, 345

Solar thermal, 1, 50

South Carolina, 429

South Dakota, 430

Southeastern Power Administration, 332

Southwestern Power Administration, 333

Soviet designed reactors, 251

Specifications ASTM, 461

Speed Limit, 364

Spent nuclear fuel, 281 transportation, 288

SSC, 194

Standards for materials, 460

Stanford Linear Accelerator, 327

State and local government energy programs, 80

Statistical policies, 144

Steel industry, 453

Storm windows, 445

Strategic Petroleum Reserve, 211, 212

Stripper Well Association, 503

Subcommittee on Energy and Power, 377

Subcommittee on Energy Regulation and Conservation, 371

Subcommittee on Energy Research and Development, 372

Subcommittee on Mineral Resources Development and Production, 373

Subcommittee on Public Lands, National Parks and Forests, 374

Subcommittee on Water and Power, 375

Supercomputer development, 181

Supercomputing facilities, 181

Superconducting Super Collider, 11, 194

Superconductivity, 53

Survey of Current Business, 339

Synchrotron radiation, 325,327

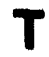

Tar sands, 5, 307, 308

Tax credits, 369

Taxes and tax credits, 368

Taxpayers Service Line, 368

Teapot Dome, 217

Technical assistance, 3, 86 
Technical information, 6, 346

Technical reports, 6, 346

Technology policy, 274

Technology transfer, 247

Tennessee, 431

Tennessee Valley Authority, 383

Tevatron, 301

Texas, 432

Thermal energy management, 55, 56

Thermonuclear plasma behavior, 188

Tight sands, 5

Tokamak Fusion Test Reactor, 303

Topographic maps, 357

Trade deficit, 338

Trade Development, 342

Transit programs, 365

Transportation energy effiriency, 63

Transportation Materials, 70

Transportation of hazardous materials, 366

Transportation of radioactive materials, 382

Transportation propulsion systems, 64

Transportation systems design, 365

Transportation Technologies, 63

Tribology technologies, 70

TVA, 383

$\mathbf{U}$

U.S. Geological Survey, 357

U.S. trade deficit, 338

U.S. Bureau of Mines, 352, 356

U.S. Council for Energy Awareness, 511

U.S. Enrichment Corporation, 252, 512

U.S. exports and imports, 338

U.S. Geological Survey, 352

UMTRA, 305

Underground Space Association, 463

Underground Space Center, 510

Underground space use, 510

University and Science Education Programs, 195

University Coal Research Program, 219

University Reactor Fuel Assistance program, 195

University Research Instrumentation program, 195

Unsolicited proposals, 233

Uranium enrichment production plant, 315

Uranium enrichment services, 512

Uranium Mill Tailings Radiation Control Act, 382

Uranium Mill Tailings Remedial Action, 305

Uranium Programs, 252

USCEA, 511

USGS, 352,357

Utah, 433
Utility appliance rebate programs, 471

Utility Systems Division, 52

Utility technology, 44

V

Vehicle registrations, 363

Vehicle-miles traveled, 363

Ventilating Institute, 484

Vermont, 434

Virginia, 435

Virgin Islands, 436

Volcanoes, 357

W

Washington, 437

Waste detoxification, 57

Waste heat recovery, 55, 56

Waste lubricating oil, 5

Waste Management, 7, 152

Waste management at DOE sites, 153

Waste management operations, 150

Waste Material Management, 57

Waste products utilization, 55

Waste Reduction Technologies, 55

Waste sites, 150

Waste stream detoxification, 55

Water conservation, 472

Weapons and Materials Planning, 29

Weapons Complex Reconfiguration, 31

Weapons design and safety research, 27

Weapons technology, 27

Weapons-related R\&D programs, 20

Weather data, 345

Weatherization assistance, 348

Weatherization Assistance Program, 83, 85

Weatherstrips, 445

Weldon Spring Site Remedial Action Project, 314

West Valley, New York, 306

West Virginia, 438

Western Area Power Administration, 334

Wind, 1

Wind data, 345

Wind energy, 46

Wind/Hydro/Ocean Division, 46

Window films, 445

Wisconsin, 439

Women-owned businesses, 42

Wood

insulating properties, 457

Wood Energy Institute, 483

Wood fuel combustion facilities, 383 
Wood Heating Alliance, 483

Wood residue production and use, 383

Woody biomass, 336

Worker safety practices, 118

Wyoming, 440
$\mathbf{Y}$

Y-12 Production Facility, 314

Yucca Mountain, 281

Yucca Mountain Site Characterization, 286 

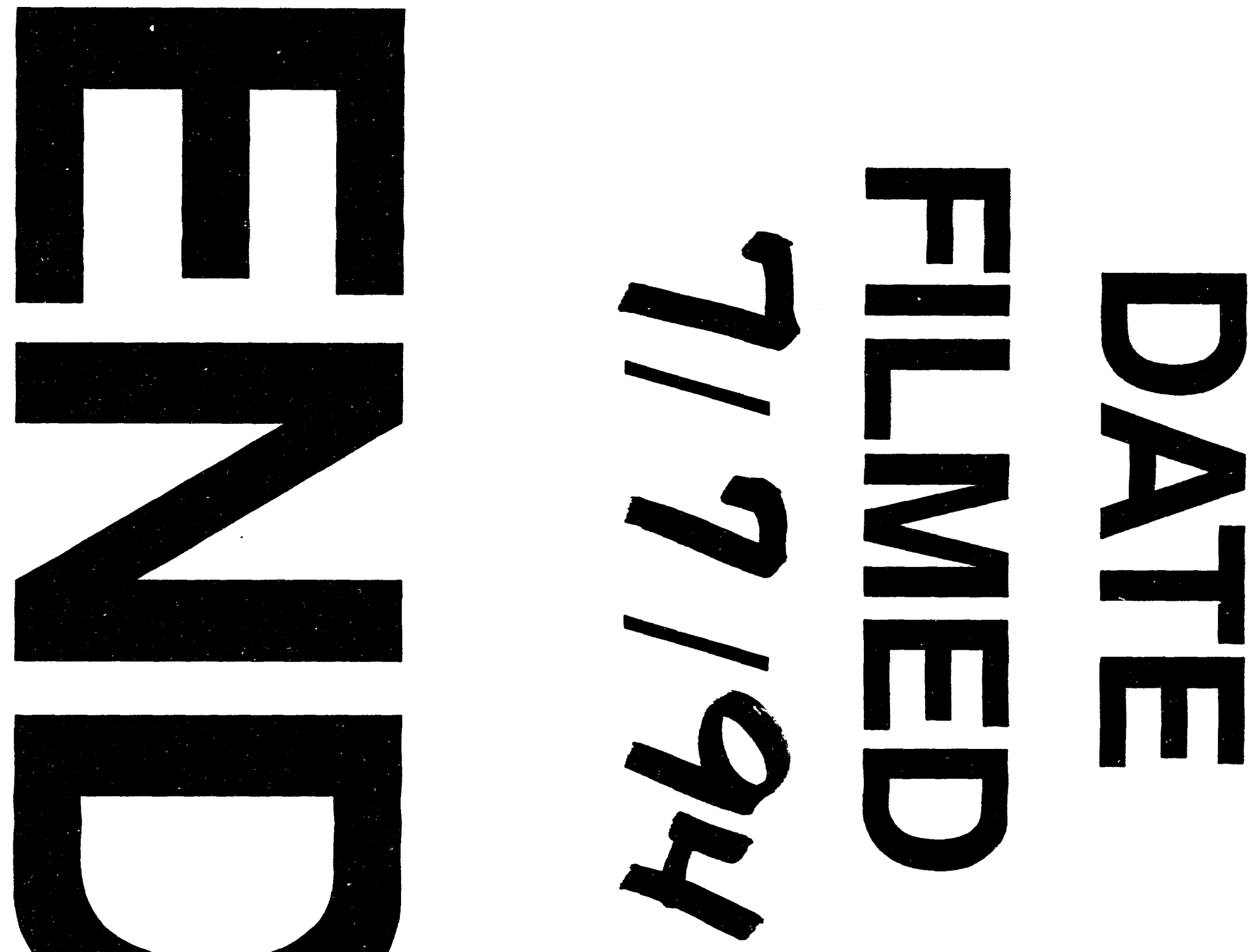

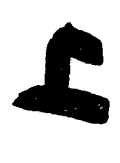

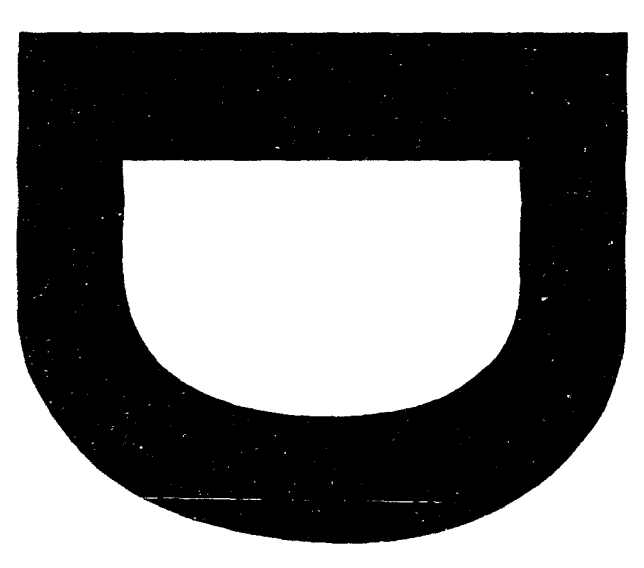

